BEATRIZ CARDOSO MONTANHANA

\title{
OS DIREITOS FUNDAMENTAIS DO TRABALHADOR E AS ESTRUTURAS SOCIAIS DE PODER DAS RELAÇÕES DE TRABALHO: EM BUSCA DO CONSENSO SOBRE A DIGNIDADE HUMANA
}

\begin{abstract}
Tese de Doutorado apresentada à Banca Examinadora da Faculdade de Direito da Universidade de São Paulo, como exigência parcial para a obtenção do título de Doutor em Direito, sob orientação da Profa. Titular Walküre Lopes Ribeiro da Silva.
\end{abstract}

FACULDADE DE DIREITO DA USP

SÃO PAULO 


\section{DEDICATÓRIA}

Dedico este estudo a todos aqueles que acreditam na melhoria das condições de vida e de trabalho, simplesmente porque reconhecem dentro si a condição humana. 


\section{AGRADECIMENTOS}

Ao final da pesquisa e da redação deste trabalho, concluí que as tantas laudas, agora impressas diante dos meus olhos, retratam um caminhar infinito em busca da compreensão do mundo.

Uma tese representa a somatória dos anos de estudo, os quais não traduzem nada, se não são dedicados à tentativa da melhoria de si mesmo como ser humano. Nessa jornada em curso, vários companheiros cruzaram o meu caminho e permitiram que o meu olhar para o outro se aprimorasse a cada dia.

Devo agradecer cada sorriso, cada lágrima, cada gesto, cada palavra que recebi e compartilhei com cada semelhante, porque a vivência e a convivência com tantas pessoas, em sincronia com a ordem natural das coisas, formataram a minha experiência de vida.

Dedico meus agradecimentos especialmente às pessoas que confiaram em mim, durante os últimos três anos devotados à reflexão do tema deste estudo.

Agradeço ao Dr. Hiroshi Kimura, Gerente Regional do Trabalho e Emprego da Zona Leste - São Paulo, brilhante colega, que, por meio da sua generosidade, nos motiva a crescer profissionalmente. Agradeço ao Dr. Cláudio da Silva, aos meus colegas AuditoresFiscais do Trabalho e servidores da GRTE-III/Leste, queridos companheiros dedicados ao trabalho diário em prol da melhoria das condições de vida dos trabalhadores.

Agradeço aos meus amigos Ana Clarissa Masuko dos Santos Araújo e Antonio Jose Treno Rita, presentes em minha vida desde os idos anos da graduação. Agradeço às minhas amigas Cleonice da Silva Pereira ("responsável direta" pela minha inclinação pelo tema “Direitos Humanos”) e Danielle Uchiyama. Agradeço a meus inesquecíveis amigos de infância, Luciano Leocádio Mendes da Silva e Lucimara Leocádio Mendes da Silva.

Agradeço ao Francisco José Treno Rita, pelo amor e dedicação desde que nos conhecemos, há pouco mais de seis meses; tão pouco tempo do ponto de vista cronológico, mas tempo incalculável sob a óptica do sentimento

Agradeço à minha orientadora Prof ${ }^{a}$ Walküre Lopes Ribeiro da Silva, por se dispor a acompanhar mais essa etapa da minha vida, com toda dedicação e compreensão da profissional, mas, acima de tudo, com a sua inteligência, o seu companheirismo e a sua sensibilidade incomparável, que inspiram e motivam os que a cercam. 
Agradeço aos meus avós (in memoriam) Gotardo, Angela, Raimunda e José Pedro Cardoso, o "Vô Cardoso", trabalhador da estrada de ferro Araraquarense, entre os anos de 1930 e 1960, de cujos grifos nos artigos da CLT, sobre o serviço ferroviário, lembro-me com muito carinho.

Imensamente agradeço à minha prima Áurea Cardoso de Oliveira, sempre disposta a dar uma palavra de estímulo, de carinho e de generosidade, mesmo longe dos olhos, mas tão perto d'alma.

Toda gratidão às minhas "titias do coração" Avanda Maria Cardoso, Ciniria Sonia Cardoso e Darcy Aparecida Cardoso, pela compreensão e pelo amor com que continuam brindando todos os dias da minha vida.

Eterno agradecimento aos meus amados pais Anézia Cardoso Montanhana e Benedito Montanhana, por terem me dado a oportunidade de viver e por terem me conduzido nos primeiros passos da infinita e magnífica caminhada do saber.

Agradeço a Deus, acima de tudo. 
"When I use a word", Humpty Dumpty said, in rather a scornful tone, "it means just what I choose it to mean neither more nor less"

"The question is", said Alice, "whether you can make words mean so many different things."

"The question is", said Humpty Dumpty, "which is to be master - that's all".

(Lewis Carroll, Alice through the looking-glass)

“ 'Para onde foi Deus?', clamou ele, 'eu vos quero dizê-lo! Nós o matamos, vós e eu! Nós todos somos seus assassinos? Como, porém, fizemos isso? Como pudemos tragar o oceano? Quem nos deu a esponja para remover o horizonte inteiro? Que fizemos nós quando desprendemos esta Terra de seu sol? Para onde se move ela, então? Para onde nos movemos nós? Longe de todos os sóis? Não nos precipitamos sem cessar? E para trás, para o lado, para frente, de todos os lados? Há ainda um alto e um baixo? Não erramos como através de um nada infinito? Não nos bafeja o espaço vazio? Não ficou mais frio? Não vem, sem cessar, sempre a noite e mais noite? Não se tem que se acender candeeiros pela manhã? Nada ouvimos ainda do rumor dos coveiros, que sepultam Deus? Nada sentimos ainda do cheiro da decomposição divina? - também os deuses se decompõem? Deus morreu! Deus permanece morto! E nós o matamos!"”. (NIETZSCHE - Gaia Ciência, aforismo 125)

Science, sans conscience, n'est que ruine de l'âme.

(Rabelais, Pantagruel, Chap. VIII ) 


\section{RESUMO}

O presente estudo visa analisar o sentido da dignidade do trabalhador na estrutura das relações de trabalho subordinado no Brasil. A noção de trabalho digno traduz a complexidade da sociedade capitalista e seu caráter essencial tanto como fator de produção (estrutura econômica) quanto como fonte de sobrevivência e inserção na comunidade (estrutura social e psicológica). A constatação da complexidade não é causal, pois exige esforço de reflexão que ultrapassa o empirismo e a certeza decantada pelo cientificismo. Faz-se uma singela digressão histórica sobre as bases do pensamento científico e de como o científico distanciou-se do humano, indagando sobre a influência do paradigma da racionalidade na formatação da dogmática jurídica positivista. Em um segundo momento, discute-se como as relações de trabalho subordinado acentuaram o problema da pluralidade de interesses, valores e expectativas, o que contradiz um paradigma moldado pela redução da complexidade. Uma vez identificado esses conflitos, a proposta de uma nova maneira para vislumbrar as relações de trabalho subordinado faz-se necessária. Apresenta-se aqui um estudo baseado no pensamento sistêmico/complexo, com enfoque na complexidade presente na relação entre as estruturas econômica (empregador) e psicológica (trabalhador). Cada uma dessas esferas compartilha uma base de referência do sistema social, o que possibilita a presença de diferentes padrões para compreender e interpretar a dignidade humana. No estudo sobre o Sistema Federal de Fiscalização do Trabalho - como representante do Estado de Direito - destaca-se o impacto desse instrumento como promotor do cumprimento fiel da legislação de proteção ao trabalho. Por fim, discute-se a posição da dignidade humana na Constituição Federal de 1988 e como alicerce da estrutura do sistema juslaboral. Explora-se a temática relativa aos acidentes de trabalho e a promoção da dignidade humana no ambiente de trabalho, dados os diferentes e os complexos parâmetros de que partem o empregado e o empregador no cenário brasileiro. Verifica-se que as relações de trabalho subordinado envolvem muito mais do que a organização de um meio ambiente física, biológica e quimicamente considerado, mas compreendem as interações entre os indivíduos e suas expectativas no ambiente social.

Palavras-chave: direitos fundamentais; dignidade humana; pensamento sistêmico; relações de trabalho subordinado; fiscalização do trabalho. 


\section{ABSTRACT}

The present research aims to analyze the meaning of worker's dignity in the labor relations in Brazil. The decent work translates the capitalist society's complexity and its essential character as a production factor (economic structure) as a survival resource and way of being part of a community (social and psychological structures). The knowledge of complexity is not based on causality, because it requires reflection efforts that go beyond the empirism and the certainty asserted by the scientificism. It is important to make a simple historical digression into the basis of scientific thinking and the distance between scientific knowledge and human essence, asking about the influence of the rationality paradigm on the constitution of legal positivism as a theory. After that, it is discussed how the labor relations, characterized by legal subordination, increased the problem of plurality of interests, values and expectations. This fact is contrary of a paradigm modeled by the complexity reduction. As the conflicts are identified, it is fundamental to purpose a new way of contemplate the labor relations. It is presented a study based on systemic/complex thinking that emphasizes the complexity inherent to the relation between the economic structure (employer) and the psychological structure (employee). Each one of these aspects shares its reference basis of social system, that makes possible the presence of the different patterns to understand and to interpret the human dignity. In the research of Federal System of Labor Inspection - as the representant of the Brazilian Federal State and this corresponds to Occupational Safety and Health Administration (OSHA) -, it is important to underline the impact of this public service as a mechanism for promoting the compliance of the employment protection legislation. At last, it is discussed the position of human dignity in the Federal Constitution of 1988, as the basis of the labor law system. The labor accidents and the promotion of the dignity of human work in the labor environment are explored topics, considering the differents and the complex patterns to which employers and employees become attached in the Brazilian labor market context. It is verified that the labor relations involve much more than physical, biological and chemical environment organization, but they integrate the individual interactions and their expectations in the social context.

Key words: fundamental rights; human dignity; systemic thinking; labor relations; subordination; labor inspection. 


\section{RIASSUNTO}

Nel presente lavoro di tesi si discute il senso di dignità nella struttura dei rapporti di lavoro subordinato in Brasile. La nozione di lavoro degno tradusce la complessità della società capitalista ed il suo carattere essenziale come fattore di produzione (struttura economica) e come mezzo di sopravivenza ed inserzione nella comunità (struttura sociale e psicologica). La constatazione della complessità non è causale, perché lei domanda la reflessione che supera l'empirismo e la certezza del scientificismo. Una breve digressione histórica è fatta per comprendere gli elementi essenziali del pensiero scientifico e la distanza tra lo scientifico e l'umano. Dopo questo studio, si indaga su l'influenza del paradigma della razionalità nella formattazione del positivismo giurídico. Dalla seconda, si discute come le relazioni di lavoro subordinato hanno accentuato il problema della pluralità degli interessi, valori ed aspettative, lo che contradice un paradigma destinato alla reduzione della complessità. Quando questi conflitti sono riconosciuti, la proposta di un nuovo metodo di intravvedere le relazioni di lavoro subordinato è necessario. Il punto messo in evidenza è il pensiero sistemico-complesso, distacandosi la complessità presente nella relazioni tra le strutture economica (datore di lavoro) e psicologica (impiegato). Ogni ambito comparte una base di referenza del sistema sociale, lo che possibilita la presenza di differenti modelli per comprendere ed interpretare la dignità umana. Nello studio sul Sistema Federale delle Ispezione di Lavoro brasiliano - come rappresentante dello Stato di Diritto - si distacca il impacto di questo strumento come promotore dell'osservanza della legislazione di tutela del lavoro. Al fine di tutto, s'abborda la posizione della dignità umana nella Costituzione Brasiliana del 1988, come fondazione della struttura del sistema giuslavoristico. È esplorata la tematica degli accidenti di lavoro e la promozione della dignità umana nell'ambiente di lavoro, consideratti i differenti ed i complessi parametri da cui partano l'impiegato ed il datore di lavoro nello contesto brasiliano. L'obiettivo della tesi di dottorato è stato quello di verificare Che le relazioni di lavoro subordinato implicano l'organizzazione dell'ambiente fisica, biologica e chimicamente consideratto, ma anche comprendeno l'interazioni tra gli soggetti e le sue aspettative nell'ambiente sociale.

Parole chiave: diritti fondamentali; dignità umana; rapporti di lavoro subordinato; pensiero sistemico; ispezione del lavoro. 


\section{SUMÁRIO}

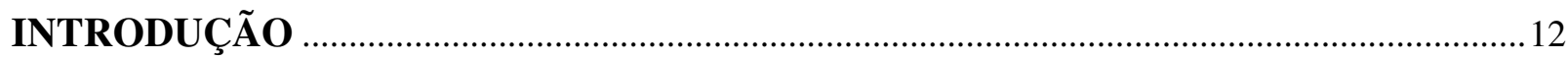

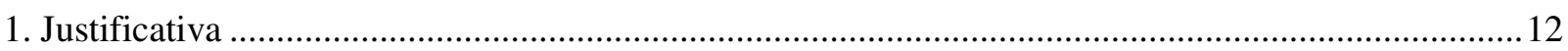

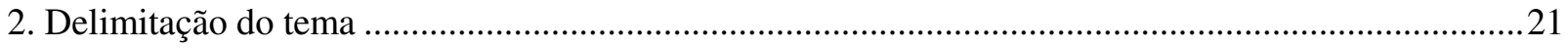

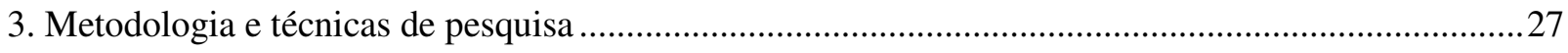

\section{CAPÍTULO I. O MUNDO DO TRABALHO E O SISTEMA JUSLABORAL: A} COMPLEXIDADE REAL E A BUSCA DO MODELO IDEAL ...................28

1. O pensamento científico: da crença no mito à crença na razão...................................28

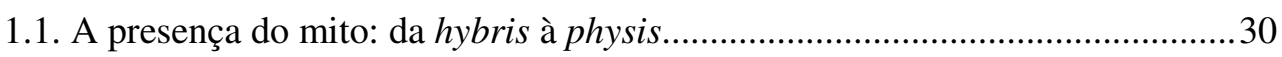

1.2. Sofistas: o princípio da impermanência e da incerteza......................................34

1.3. O pensamento platônico e o reconhecimento de um mundo ideal.....................38

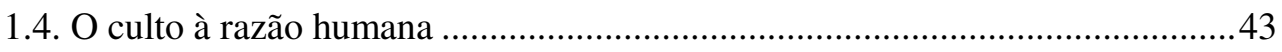

2. A racionalidade científica e sua influência no Direito ................................................49

2.1. A disciplina do agir humano para os antigos ................................................49

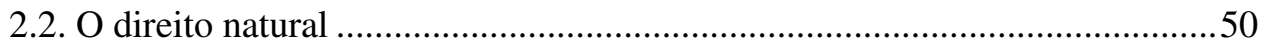

2.3. O contratualismo social: a criação da ordem sócio-política e jurídica

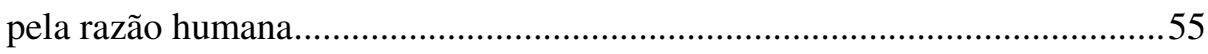

2.4. A construção do paradigma da modernidade .................................................60

2.5. O positivismo jurídico e o processo de codificação como expressão da racionalidade científica no Direito

3. A complexidade das relações de trabalho subordinado e os direitos humanos sociais .64

3.1. A presença do poder das relações de trabalho subordinado ............................66

3.2. O reconhecimento jurídico da complexidade: a consagração dos direitos humanos .

3.3. O conflito de racionalidades e a coerência valorativa do sistema constitucional

\section{CAPÍTULO II. EMPREGADOR E EMPREGADO: A SOCIEDADE COMPLEXA E}

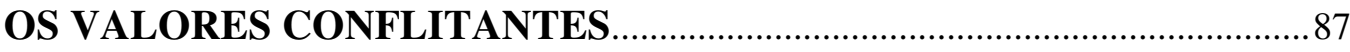

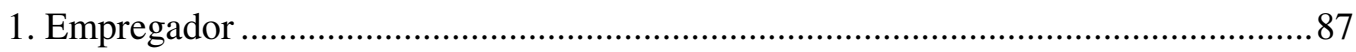

1.1. Capitalismo clássico: a crença na natureza do homo oeconomicus................87

1.2. O trabalho como valor na sociedade capitalista: o valor de mercado ............91 
1.2.1. O direito à redução de riscos no meio ambiente do trabalho no ordenamento jurídico brasileiro: o alcance da dignidade do trabalhador...

1.2.2. O referencial do sistema econômico e as medidas para redução de risco no ambiente de trabalho................................................................. 102

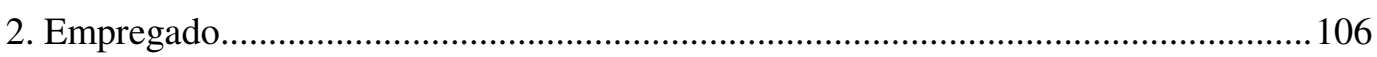

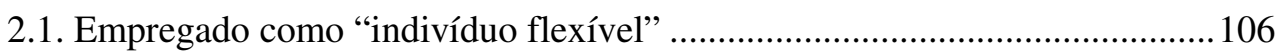

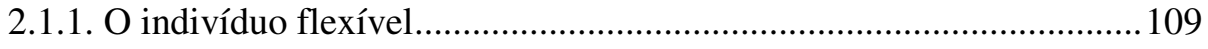

2.1.2. Organização do trabalho versus "desorganização" do indivíduo

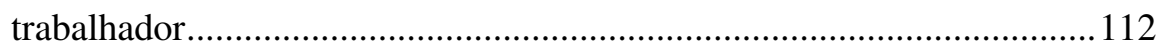

2.2. Do homem abstrato para o homem concreto ……................................116

2.2.1. A liberdade como "propriedade". 116

2.2.2. O processo de significação do trabalho na sociedade complexa: o exemplo da noção de carreira .................................................................. 120

2.2.3. De Sísifo a Proteus: as metáforas da pós/hipermodernidade... 123

\section{CAPÍTULO III. CONSIDERAÇÕES SOBRE UMA DAS FORMAS DE ATUAÇÃO ESTATAL: A CONVIVÊNCIA ENTRE OS "INTERESSES PRIVADOS” E O SISTEMA FEDERAL DE FISCALIZAÇÃO DO

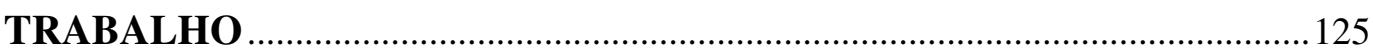

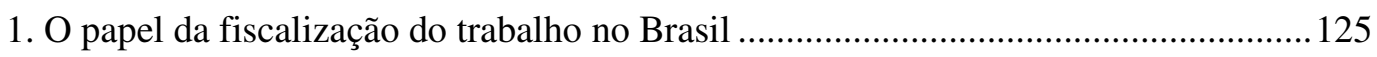

1.1. Da dominação física à organização do trabalho ............................................125

1.2. Por uma organização digna do trabalho ......................................................... 129

1.3. A importância da fiscalização do trabalho ...................................................... 132

1.4. Convenção n. 81 da Organização Internacional do Trabalho ........................ 135

1.5. Breves considerações sobre a fiscalização do trabalho no Brasil ..................137

1.6. O fundamento da fiscalização do trabalho no Brasil: a ordem pública..........140

2. A observação "in loco": a fiscalização do trabalho como instrumento imediato de promoção dos direitos fundamentais do trabalhador

2.1. Fiscalização do trabalho no Brasil: intervenção na esfera privada ou participação na construção do sentido da dignidade? 147

2.2. Conceitos indeterminados 152

2.3. O desafio da eficácia horizontal dos direitos humanos nas relações de trabalho 156

2.4. Reserva do possível face à fiscalização do trabalho 159

2.5. "Flexibilização": por um sistema jurídico maleável? 161 


\section{CAPÍTULO IV. A DIGNIDADE COMO FUNDAMENTO DA ORGANIZAÇÃO DAS RELAÇÕES DE TRABALHO SUBORDINADO}

1. A integração do Direito do Trabalho no Brasil em torno da dignidade humana .........169

1.1. O sentido da dignidade e os direitos fundamentais dos trabalhadores ..........169

1.2. A dignidade no trabalho como conceito indeterminado................................172

1.3. A presença da liberdade nas relações de trabalho no Brasil..........................178

2. Uma análise sobre a dignidade e a monetarização (tarifação) da saúde e da vida do trabalhador

2.1. O modelo de reparação/compensatório versus o valor da saúde e da vida do trabalhador para a sociedade: a questão da base de cálculo do adicional de insalubridade.

2.2. O risco da ineficiência das medidas compensatórias 195

2.2.1. Seleção adversa (informação escondida). 196

2.2.2. Risco moral (moral hazard)

2.2.3. Contratos incompletos

2.3. O excesso de comunicação no sistema jurídico: o modelo da responsabilidade subjetiva do empregador por acidentes de trabalho à luz do Código Civil de 2002

2.4. Modelo de responsabilidade civil extracontratual.........................................203

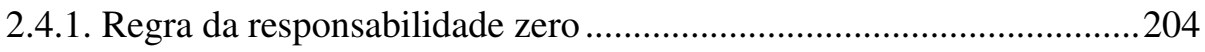

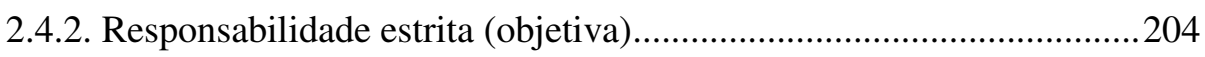

2.4.3. Responsabilidade subjetiva (culpa ou dolo) ........................................206

2.5. A coerência valorativa do sistema juslaboral laboral e a adoção da jornada de $12 \mathrm{X} 36$.

2.6. O poder da organização do trabalho versus liberdade do trabalhador: em busca da dignidade humana 


\section{INTRODUÇÃO}

\section{Justificativa}

O presente estudo apresenta como tema central a análise do sentido da dignidade do trabalhador na estrutura das relações de trabalho subordinado no Brasil.

O desenvolvimento do tema central permeia temas secundários, os quais comportam premissas para o questionamento sobre a busca da apreensão do sentido da dignidade humana nas relações de trabalho subordinado, no contexto de uma sociedade marcada pela pluralidade e complexidade.

O primeiro subtema a ser abordado envolve a complexidade que a noção de trabalho traduz no contexto da sociedade capitalista e o caráter essencial que imprime nas relações humanas, tanto como fator de produção (estrutura econômica) quanto como fonte de sobrevivência e inserção na comunidade (estrutura social e psicológica). Contudo, a constatação da complexidade não é causal, ou seja, demanda esforço de reflexão que ultrapassa o empírico e a certeza decantada pelo cientificismo. Admitir a complexidade é ir além do que é aparente. E, por isso, far-se-á uma singela digressão histórica sobre as bases do pensamento científico e como o científico distanciou-se do humano.

Justifica-se essa abordagem na medida em que admitir a complexidade permite reconhecer que o sentido da dignidade perpassa as esferas presentes nas relações entre empregado e empregador, ou seja, um contexto complexo e plural. Inicialmente, no primeiro capítulo, constatar-se-á que a modernidade rompe com a tradição de valores transcendentais, ao adotar o paradigma técnico-científico do conhecimento, traduzido na crença da razão humana. Propõe-se a perquirição sobre a influência do paradigma da racionalidade na formatação da dogmática jurídica positivista. Importante observar que o conhecimento humano não se pautou, desde o princípio, na razão. Os mitos exerceram papel fundamental para a compreensão do mundo fenomênico. E, da mesma forma que os mitos inspiravam as crenças em deidades, a razão passou a ocupar seu lugar. Nesse sentido, lembra-se a tentativa dos revolucionários franceses do século XVIII de introduzir o Culto à Razão (le culte de la raison), assim como o Culto ao Ser Supremo (le culte d'Être Suprême). Por fim, o foco da discussão no primeiro capítulo repousa sobre o dilema 
entre o modelo de certeza do positivismo científico e a complexidade da realidade social. Em especial, as relações de trabalho subordinado acentuaram o problema da pluralidade de interesses, valores e expectativas, o que contradiz um paradigma moldado pela redução da complexidade.

Uma vez identificado esse conflito, a proposta de uma nova maneira para vislumbrar as relações de trabalho subordinado faz-se necessária. Apresenta-se aqui um estudo baseado no pensamento sistêmico/complexo. Estabelecer-se-á um diálogo com alguns dos expoentes da Teoria dos Sistemas, sem firmar aqui a pretensão de esgotar toda a amplitude dessa corrente epistemológica ${ }^{1}$. A exploração desse tema objetiva suscitar o debate acerca da viabilidade de uma nova forma de conhecer o Direito do Trabalho e da importância de garantir a integridade do sistema juslaboral.

No segundo momento, a abordagem temática encaminha-se para o estudo dos dois subsistemas inerentes às relações de trabalho subordinado. Desse subtema depreende-se grande complexidade presente na relação entre as estruturas econômica (empregador) e psicológica (trabalhador). Cada uma dessas esferas compartilha uma base de referência do sistema social mais abrangente e do qual são partes. $O$ todo e a parte contribuem simultânea e ininterruptamente para a construção de sentidos, de modelos e de valores, porém cada qual realiza e procede à interpretação dos fatos com base nos elementos estruturais e organizacionais que constituem o seu sistema próprio. Nota-se, então, a possibilidade de diferentes padrões de referência que podem ser adotados para compreender e interpretar a dignidade humana, premissa essa que evidencia a complexidade da sociedade do trabalho.

No terceiro capítulo, propõe-se uma análise dos conflitos gerados a partir da necessidade de afirmar um sentido para as normas trabalhistas, com base na ordem constitucional vigente, e os interesses manifestados pelos sujeitos. Em um contexto de complexidade, o sentido dos direitos sociais fundamentais é um construído que envolve os valores e os interesses das partes do contrato de trabalho subordinado: empregado e empregador. E, com vistas a explorar essa questão, o terceiro subtema aborda a atuação do Sistema Federal de Fiscalização do Trabalho - como representante do Estado de Direito e,

\footnotetext{
${ }^{1}$ Por sistema, entende-se uma estrutura organizada, constituída por elementos, que "não pode operar além dos limites que o constituem como tal, que o designam como unidade; isto é, não pode operar como se fossem capilares ou redes que se comunicam diretamente - relação causal (causa e efeito): contato, toque, contaminação". (RODRIGUES, Léo Peixoto. Sistemas auto-referentes, autopoiéticos: noções-chave para a compreensão de Niklas Luhmann. Revista Pensamento Plural, Pelotas, v. 3, p. 111, jul./dez. 2008).
} 
portanto, da ideia de unidade de valores em torno da Constituição (sistema jurídico) - em contato com as estruturas dos subsistemas econômico (empregador) e psicológico (trabalhador) das relações de trabalho subordinado, destacando-se o impacto desses conflitos na sociedade. Identificar-se-á, pois, que "ruídos", "perturbações" ou "irritações" são inevitáveis e será questionado de que forma esse fenômeno pode contribuir para a desintegração do sistema juslaboral.

Por fim, o quarto subtema versa sobre a dignidade. Discutir-se-á a posição da dignidade humana na Constituição Federal de 1988. Em princípio, incluída no texto constitucional como fundamento da República Federativa do Brasil, a dignidade constitui o alicerce da estrutura do sistema juslaboral. Dessa maneira, a estrutura e as funções do sistema do Direito do Trabalho dependem da apreensão do sentido da dignidade humana. A fim de ressaltar a dinâmica que nasce dessa questão eminentemente teórica, será explorado o grande problema dos acidentes de trabalho e a promoção da dignidade humana no ambiente de trabalho, dados os diferentes e os complexos parâmetros de que partem o empregado e o empregador no cenário brasileiro.

O tema proposto, portanto, envolve a articulação de várias questões: direitos fundamentais do trabalhador, bases epistemológicas, estrutura e organização do trabalho subordinado e o suporte referencial dos atores sociais (econômico e psicossociológico) para a compreensão da dignidade humana.

É possível declinar mais de uma justificativa para a escolha do tema da tese proposta.

Uma delas repousa na importância de, em tempos de globalização e ameaças perenes à base legislativa de proteção ao trabalho, promover um estudo voltado à perquirição sobre o sentido da dignidade do trabalhador.

A História encaminhou-se para reconhecimento da necessidade da previsão dos direitos humanos em um contexto geral. Especialmente quanto aos direitos humanos do trabalhador, a visão abstracionista do homem cedeu lugar à realidade material das relações de trabalho e a proteção do trabalhador constituiu a tônica dos chamados Estados Sociais. Contudo, a pluralidade de interesses e valores caracteriza as relações sociais e a compreensão sobre o alcance da promoção de direitos fundamentais se perde em uma rede de ações com referenciais diversos. Terminologicamente, por direitos fundamentais 
entendem-se, para os fins desse estudo, os direitos humanos consagrados pela Constituição de um Estado.

O desafio torna-se mais pungente quando o impasse envolve fundamentos, limites ou reflexões sobre a dignidade do trabalhador. O contexto atual aponta dificuldades que sobrelevam a importância do significado da dignidade do trabalhador, dentre elas, a competição no mercado e o discurso pela redução dos mecanismos de proteção ao trabalho, em nome de custos de produção cada vez mais baixos, em prejuízo da qualidade e da garantia da saúde e da vida dos trabalhadores. E essas dificuldades constituem matizes da presença de interesses conflitantes na sociedade. Para estudá-los, tende-se a reduzir a complexidade por meio da análise singular de cada pólo envolvido - empregado e empregador -, porém com o diferencial de que a complexidade é reconhecida como uma premissa inafastável das relações de trabalho subordinado.

O Direito, por sua vez, apresenta-se como um modelo de disciplina de condutas, com estrutura e organização próprias. Portanto, o Direito não é mera descrição do que "deve-ser", cujo conteúdo é conhecido a partir de uma relação cartesiana sujeito-objeto. A ideia de Direito pressupõe a ideia de vínculo: o agir de um está vinculado e interfere no agir de outro, o qual, por sua vez, reverbera seus efeitos no primeiro. Mas no Direito, ontologicamente, não se aplica o binômio causa-efeito. O sujeito de direito não se debruça sobre o conteúdo de uma norma jurídica como um cientista que, alicerçado pela certeza da física clássica, examina as condições de temperatura, volume e pressão em um experimento. E, nesse ponto, há de se destacar que foi da própria Física, por meio dos fenômenos atômicos, a descoberta do princípio da incerteza: a matéria assume aspecto dual - o que afronta o princípio da não-contradição - e o que se pode "prever" são probabilidades.

Assim, a justificativa para a escolha desse estudo parte da importância da evolução da ciência para a compreensão e a configuração das relações humanas, dentre elas, as de trabalho subordinado. Da mesma forma que a visão dogmática e positivista modelou o Direito, o princípio da incerteza e da probabilidade resgatam a noção de complexidade e de que as "coisas" não existem por si, ou seja, não há conceitos absolutos; o que há são relações.

Isso não significa a primazia do relativismo e o fim da "segurança jurídica". Mas a constatação de que a construção de um padrão - ou mesmo estrutura - de uma sociedade é resultado de um diálogo, isto é, de interconexões. A segurança assenta-se na presença 
efetiva dessas interconexões e não na sobreposição de um "ideal absoluto" - por exemplo, supervalorização do econômico-financeiro- sobre os demais.

O Direito imprescinde da noção de alteridade, aqui entendida como a capacidade de se reconhecer no outro, como um indivíduo criativo e apto a realizar o pleno desenvolvimento de sua potencialidade. Para compreender o outro, é necessário traçar um panorama das suas matrizes e, no Direito, a ideia de valor permite identificar como se organiza um determinado subsistema. O valor - rechaçado pelo positivismo jurídico corresponde ao incerto e ao provável que não se afasta do universo jurídico. Fritjof Capra destaca que "ao transcender a divisão cartesiana, a física moderna não só invalidou o ideal clássico de uma descrição objetiva da natureza, mas também desafiou o mito da ciência isenta de valores". ${ }^{2}$

Por essa razão, também se motiva essa abordagem pela associação que existe entre os direitos humanos e o resgate da noção de valor humano. É interessante notar que as várias discussões sobre o universalismo versus relativismo dos direitos humanos traduzem o dilema paradigmático presente no Direito: não se admite o incerto (relativo, contrário ao cartesiano), mas também não se quer assumir o universal (absoluto, que, nas ciências humanas, não empíricas, não poderia ser alcançado). Mas ocorre que os direitos humanos estariam próximos ao referencial do princípio da incerteza: não é possível ter certezas, mas probabilidades. Na física quântica, percebeu-se que, dependendo da forma como o sujeito observa o objeto, a natureza do objeto sofre alteração. Da mesma forma, de acordo com a maneira como o homem é visto na sociedade, ele pode ser meio ou fim, isto é, pode ou não ter dignidade. E isso deriva da posição do observador, isto é do modelo adotado, porque "os modelos que os cientistas observam na natureza estão intimamente relacionados com os modelos de sua mente - com os conceitos, pensamentos e valores" ${ }^{3}$. E, segundo Niklas Luhmann, "o sujeito só pode manter-se graças à lógica dos valores e à própria distinção entre verdade e falsidade dos objetos do mundo, para que ele mesmo possa ser superado" 4 .

Superação não significa destruição. O sujeito, ao interagir com o meio, torna-se observador e objeto simultaneamente. O homem, portanto, é um sistema que se reproduz dinamicamente, pelo conhecimento do ambiente e pelo autoconhecimento. Para que ele

\footnotetext{
${ }^{2}$ CAPRA, Fritjof. O ponto de mutação: a ciência, a sociedade e a cultura emergente. Trad. Álvaro Cabral. 11. ed. São Paulo: Cultrix, 1990. p. 81.

${ }^{3}$ Id., loc. cit.

${ }^{4}$ LUHMANN, Niklas. Introdução à teoria dos sistemas: aulas publicadas por Javier Torres Nafarrate. Trad. Ana Cristina Arantes Nasser. Petrópolis: Ed. Vozes, 2009. p. 355.
} 
possa se conhecer e se reproduzir é necessário que o seu sistema não seja destruído. Há, portanto, pressupostos. Luhmann lembra que “o mundo (definido seja como for) está sempre pressuposto como condição da possibilidade de que possamos falar, escrever e nos comunicar eletronicamente" ${ }^{\natural 5}$. Do mesmo modo, para que o homem exista como ser vivo capaz de satisfazer suas necessidades básicas, estão pressupostos alimentação, higiene e abrigo. Mas o ser humano ultrapassa as fronteiras do biológico. O homem, já afirmava Aristóteles, é um ser político. Sem entrar no mérito das implicações filosóficas da máxima aristotélica, o homem vive em sociedade e a escolha pela construção de uma sociedade democrática pressupõe a dignidade humana. É inevitável não parafrasear Luhmann: a dignidade (definida seja como for) está sempre pressuposta como condição da possibilidade de interação, comunicação e mesmo existência. O sentido de dignidade não é um dado de uma racionalidade superior, intangível, mas um construído. E aqui entram os direitos humanos, como fruto do reconhecimento da incerteza e da crise da racionalidade objetiva e neutra.

Essa dinâmica não é simples, como aponta Humberto Maturana e Francisco Varela. Para compreender a organização e sua circunstância - o entorno ou o contexto com o que está conectado -, seria necessário um certo distanciamento que, se é possível quando se trata de uma máquina projetada pelo homem, "não é simples quando se trata de seres vivos, porque sua gênese e sua história jamais nos serão diretamente visíveis e só podem ser reconstruídas de modo fragmentário"6.

Sem a pretensão de adotar uma teoria específica e diante da necessidade de um referencial epistemológico que contemple a complexidade, pela via do pensamento sistêmico/complexo propor-se-á a identificação das bases da organização e da estrutura dos subsistemas dos sujeitos que celebram o contrato de trabalho subordinado: empregado e empregador. Quanto à presença do Estado nessa relação, a fim de restringir a amplitude desse subtema, a tese limitar-se-á a abordar a atuação do Sistema Federal de Fiscalização do Trabalho, como exemplo da presença do sistema jurídico-estatal nas relações de trabalho subordinado.

Nas relações de trabalho destaca-se a característica intrínseca de se desenvolverem em um ambiente de conflito entre as partes (empregado e empregador). No Brasil, a fim de

\footnotetext{
${ }^{5}$ LUHMANN, Niklas. op. cit., p. 269.

${ }^{6}$ MATURANA, Humberto R.; VARELA, Francisco J. A árvore do conhecimento: as bases biológicas da compreensão humana. Trad. Humberto Mariatti e Lia Diskin. 6. ed. São Paulo: Palas Athena, 2007. p. 68.
} 
"gerenciar" os interesses antagônicos, o Estado propôs um modelo de integração da relação: a Consolidação das Leis do Trabalho. Não há, tecnicamente, um sistema de normas, mas a reunião de várias normas disciplinadoras das relações de trabalho subordinado. As normas trabalhistas são elaboradas e passam a prescrever condutas, segundo uma ordem de valores e um sistema de referência que estruturam o ordenamento jurídico. Destarte, existem componentes e organização da estrutura jurídica que conformam os elementos das relações de trabalho subordinado. A questão ganha maior realce no campo trabalhista, em que se contempla o pluralismo jurídico. Diante de uma sociedade pluralista, em que as relações são pautadas pela diversidade de interesses, os conflitos são inevitáveis. Conhecer os interesses em jogo constitui informação imprescindível para definir projetos cujos impactos repercutem no todo social.

Um exemplo será objeto mais destacado desse estudo: as informações econômicas e o risco da ruptura do sistema juslaboral. A questão que Niklas Luhmann propõe é simples e pontual: é possível fazer com que informações - por exemplo, sobre o desemprego -, dependam da operação fechada da economia, como análise de "balanços, preços, a atuação da concorrência, aumento ou redução da demanda"? Nessa hipótese, Luhmann conclui que somente um observador poderia vislumbrar a sintonia da informação entre a economia e o mercado de trabalho, ainda que a informação tenha sido gerada dentro do sistema ${ }^{7}$. Ou seja, mesmo que o observador não tenha acesso ao processo de geração da informação, a ele é possível identificar como a informação de um sistema se comunica com outro sistema. Conflitos são gerados e Luhmann afirma que os pontos comuns surgem colateralmente ao longo do tempo, a partir de um processo de operações de expectativas e dupla contingência. $\mathrm{O}$ fator tempo - não valores a priori, absolutos, universais - promove os valores não conflitantes. Por isso, a base do modelo adotado por Luhmann, com inspiração em Parsons, é temporal e não de caráter hierárquico ${ }^{8}$.

Mas se o hierárquico em Luhmann está próximo à ideia de estratificação social, não se exclui a hipótese de o poder - inegavelmente presente na sociedade - ser resultado da temporalidade. E enquanto não houver uma proposta de poder aceita, o conflito persiste entre os sistemas. No Direito do Trabalho, essa realidade é plenamente observável, em face da presença do pluralismo jurídico. Ademais, por conta do pluralismo, os conflitos não são travados exclusivamente entre sistemas, mas também no interior deles mesmos.

${ }^{7}$ LUHMANN, Niklas. op. cit., p. 143.

${ }^{8}$ Id. Ibid., p. 320. 
François Rigaux chega a admitir que

Mesmo quando a concorrência entre elas é menos sanguinária, as ordens jurídicas disputam o poder de uma maneira anárquica que é a negação do que se quis apresentar como ideia de direito. De resto, o conflito a que se assiste hoje não tem como única causa a coexistência de ordens jurídicas que se deixam facilmente circunscrever e identificar. Nenhuma delas, mesmo isolada, está imune a conflitos internos. ${ }^{9}$

As dificuldades assomam quando o conflito versa sobre o significado de uma palavra ou termo incorporado normativamente. Daí a importância de avançar no campo epistemológico e a justificativa de se recorrer ao pensamento sistêmico, sob uma perspectiva discursiva.

Faz-se mister, portanto, apreciar o fenômeno jurídico-hermenêutico, a partir de um embasamento epistemológico, dado que a perquirição acerca da dignidade do trabalhador implica necessariamente a avaliação de bens jurídicos indisponíveis e fundamentais para a própria concepção do Direito: a vida e a saúde do ser humano.

Discutir uma base de referência sobre a dignidade humana nas relações de trabalho torna-se uma espécie de "arma" contra o chamado dumping social. A partir do desenvolvimento desse tema, extrair-se-ão substratos teóricos, com vistas a investigar o que impede a plena efetividade da dignidade humana e como conceber uma atmosfera de debate em prol do respeito e garantia da dignidade do trabalhador, elementos esses estruturantes na construção de um sistema juslaboral.

Para tanto, torna-se imperioso fomentar a discussão em torno dos fundamentos, procedimentos e referenciais que permitam a efetividade da dignidade do trabalhador, não obstante os variados interesses presentes em uma sociedade complexa e plural.

Enfim, a tese proposta almeja promover uma modesta contribuição no amplo campo de estudo da Teoria Geral de Direito do Trabalho, ao reafirmar a imprescindibilidade da abordagem sobre o alcance e o sentido da dignidade do trabalhador, em face das estruturas e das bases referenciais que permeiam as relações de trabalho subordinado. Reproduz-se aqui a declaração de Paulo de Barros Carvalho:

Estou convicto de que o hábito de certas reflexões filosóficas e o apelo frequente às categorias de Teoria Geral do Direito, longe de dificultar o acesso ao objeto da investigação, aparecem como condições mesmas do

${ }^{9}$ RIGAUX, François. A lei dos juízes. Trad. Edmir Missio. São Paulo: Martins Fontes, 2003. p. 22. 
aprofundamento cognoscitivo. E aproveito o ensejo para lembrar a lição de Pontes de Miranda, segundo a qual não há diferença entre a teoria e a prática, mas aquilo que existe é o conhecimento do objeto: ou se conhece o objeto ou não se conhece o objeto. ${ }^{10}$

As afirmações do referido autor reforçam a escolha do tema ora proposto.

A tese proposta pretende contribuir para o desenvolvimento da análise epistemológica do Direito do Trabalho. Ao contemplar o pensamento sistêmico, cogita-se em oferecer um substrato teórico para o enfrentamento de questões hermenêuticas atinentes à dignidade do trabalhador.

Diante de uma sociedade capitalista, marcada pelo pluralismo, e da necessidade de efetivar a dignidade do trabalhador, torna-se imprescindível estudar o Direito do Trabalho por um viés mais amplo que o sugerido pela dogmática formal. Os conflitos tornam-se mais complexos, exigindo uma análise abrangente, a qual, embora não ofereça soluções prontas, busca fortalecer os alicerces dos fundamentos de proteção à vida e à saúde do trabalhador.

Os desafios são muitos e, por essa razão, o estudo baseia-se no pensamento sistêmico/complexo. A concepção da dignidade do trabalhador ultrapassa os limites do sistema jurídico e, a partir do pensamento sistêmico/complexo, contempla-se a dinâmica das conexões intersubjetivas e com o ambiente. Para isso, a utilização de conceitos de teorias sistêmicas justifica-se; "irritação", "complexidade", "acoplamento estrutural" são conceitos que permitem reconhecer a realidade na condição de observador.

Em uma sociedade complexa, é indispensável um alicerce mínimo de elementos abstratos para identificar a estrutura jurídica do trabalho, a fim de que não sofra ameaças perenes ou resulte comprometida a sua organização. A complexidade presente nas relações de trabalho subordinado reflete-se em incongruências do discurso de proteção à dignidade do trabalhador quando submetido à dinâmica dos subsistemas social e econômico. No caso do Direito do Trabalho brasileiro, a autorização legal para expor o trabalhador a agentes químicos e biológicos (com prejuízo flagrante à sua saúde) justifica-se pela necessidade inconteste da realização de determinada atividade econômica. Mas diante de um ordenamento jurídico interno que prevê constitucionalmente uma ordem econômica

\footnotetext{
${ }^{10}$ CARVAlho, Paulo de Barros. Direito tributário: fundamentos jurídicos de incidência. 2. ed. São Paulo: Saraiva, 1999.. p. 5-6.
} 
fundada na valorização do trabalho humano (artigo 170, caput, da Constituição Federal), como argumentar a regra geral de incidência do adicional de insalubridade sobre o salário mínimo? Como destacou François Rigaux, já citado, não se está imune nem menos dos conflitos internos. ${ }^{11}$

Reforça-se que o foco está no pensamento sistêmico e não se pretende aqui adotar essa ou aquela teoria. Esse posicionamento está amparado exatamente na complexidade, uma das características constitutivas do pensamento e de teorias sistêmicas.

A complexidade e a fugacidade do tempo desafiam o cientista a reformular incontinentemente os seus modelos. Aliás, é exatamente essa fluidez temporal que permitiria discutir a visão luhmanniana de que os valores não-conflitantes se consolidam temporalmente. Como dimensionar o tempo hodiernamente, na sociedade do real time? Há tempo para refletir sobre a opção de rejeitar ou aceitar uma proposta? É computado esse tempo na lógica das operações pós ou hipermodernas, como alguns preferem se referir à época atual?

Tenciona-se, a partir do enfoque sistêmico, traçar contornos do comportamento do sistema de auto-referência do Direito do Trabalho e as funções que desempenha na disciplina das relações de trabalho subordinado. Não se atreve aqui a expor uma ampla e percuciente abordagem interdisciplinar. Objetiva-se contribuir para o desenvolvimento da Teoria Geral do Direito do Trabalho, a partir do esforço por debater elementos teóricos, filosóficos e jurídicos que possam conduzir à afirmação da dignidade humana do trabalhador.

\section{Delimitação do tema}

A questão principal é avaliar a busca do consenso sobre a dignidade humana nas relações de trabalho, a partir de um contexto de conflitos.

Para desenvolver a questão principal, faz-se necessário desmembrá-la em questões secundárias, que serão tratadas nos limites apresentados para o tema, ao longo de quatro capítulos.

\footnotetext{
${ }^{11}$ Ver citação 8.
} 
Ao considerar a vastidão do estudo dos direitos fundamentais do trabalhador, a complexidade psicológica, sócio-política e econômica das estruturas sociais em torno da relação de trabalho subordinado e a vasta amplitude das teorias epistemológicas, é imprescindível que as limitações ao tema estejam bem definidas.

O desenvolvimento das questões propostas pressupõe a noção de complexidade. Por complexidade, entende-se a ampla diferenciação presente na sociedade segmentada em sistemas parciais. Reconhecer a complexidade exige uma reformulação na forma de apreender os fenômenos, ou seja, uma mudança de pensamento. Por isso, no primeiro capítulo, ocupa-se da transição de modelos: do mito para razão; da certeza para a incerteza; do simples para o complexo. Inicialmente, destaca-se a importância dos mitos, os quais visam reproduzir o universo indecifrável da criação do homem e os fenômenos da natureza. A crença nos mitos cede espaço para a crença na razão, à medida que o ser humano se percebe capaz de descobrir as "leis" que governam a natureza. Uma vez que a observação percuciente leva ao conhecimento do objeto, o homem reconhece-se apto a dominar a natureza e a colocá-la à sua disposição. A ciência alicerça-se na crença na razão humana e a tecnologia é desenvolvida como fonte de bem-estar e progresso para a humanidade. Contudo, a interferência do homem sobre a natureza baseou-se na fragmentação do mundo cognoscível, a fim de propiciar melhor domínio sobre cada objeto de estudo. A simplificação decantada pela ciência fracionou o próprio homem, quando esse também foi contemplado como objeto a ser investigado cientificamente. Um exemplo elucidativo desse problema é a introdução do modelo fordista de produção e os efeitos psíquico-biológicos provocados pela extração da denominada mais valia relativa. A questão cinge-se à introdução da forma de pensamento complexo/sistêmico para analisar o Direito do Trabalho, dada a complexidade das estruturas e das funções envolvidas nesse ramo jurídico.

É inevitável apontar que, ao focar a esfera juslaboral, se busque a redução da complexidade que é o objeto central da questão. Mas é exatamente essa a razão pela qual se justifica a preferência pela abordagem do pensamento sistêmico/complexo e não propriamente de teorias sistêmicas. A interdisciplinaridade, que se encontra atrelada ao pensamento sistêmico/complexo, constitui o desafio de ampliar o olhar de observador e interagir como sujeito em meio à multiplicidade de interesses e valores na sociedade.

Ao estudar o pensamento sistêmico não se pretende discorrer amplamente sobre as teorias sistêmicas. O objetivo é constatar a necessidade de se ampliar o modo de pensar 
além dos pressupostos técnico-científicos da modernidade, reconhecida a dificuldade de superação desse paradigma.

Ao apontar as ideias centrais do pensamento sistêmico, visa-se extrair conceitos e fundamentos que estejam mais próximos da ideia de complexidade e instabilidade da sociedade e reforçar uma abordagem epistemológica do Direito do Trabalho. Por conseguinte, esse tema secundário busca abordar a limitação da chamada filosofia da consciência e considerar propostas para estudo e compreensão do Direito, precisamente do Direito do Trabalho.

No segundo capítulo, analisam-se as estruturas e a organização de dois vértices fundamentais nas relações de trabalho subordinado: empregador e empregado. A preocupação aqui está centrada na identificação do referencial adotado por cada um, como estão estruturados e como vislumbram as relações que estabelecem entre si. Essa questão é de relevada importância para indagar se há possibilidade da construção de consenso em torno do sentido da dignidade humana. A dignidade humana depende da existência do ser humano, o qual necessita, minimamente, de determinadas condições biológicas para ter vida e manter-se vivo. A questão debatida nesse capítulo envolve dois eixos: o econômico e o sócio-jurídico. A Economia preocupa-se com a utilização dos bens escassos, de sorte que essa característica acaba por determinar o valor desses bens. Nesse contexto, se o trabalho não for escasso, perde valor como bem disponível com ampla oferta. Por outro lado, a vida e a saúde são bens escassos para o ser humano individualmente considerado e, portanto, assumem valor inestimável. O trabalho não está dissociado do ser humano, mas é fruto da ação do homem vivo e, quanto mais saudável, capaz de produzir bens e serviços.

Explica-se assim a indisponibilidade conferida pelo ordenamento jurídico à saúde e à vida. Afinal, se a sociedade capitalista se alicerçou e se alicerça no trabalho, a manutenção da vida e da saúde humanas são indispensáveis para a própria conservação do sistema. Contudo, a indagação contemplada sob um ponto de vista sistêmico/complexo abrange as referências de que se valem os sistemas sociais para garantir sua organização interna e não apenas o sentido externamente fixado por um sistema mais abrangente, como o jurídico. A proposta desse estudo é, dessa forma, questionar a existência de uma gradação hierárquica dos elementos presentes nos sistemas, desenvolvida a partir da noção de valor que cada um deles atribui a partir do seu referencial. A organização estaria atrelada aos parâmetros valorativos adotados pelo sistema. 
O problema assume contornos mais acentuados quando os sistemas, ao se comunicarem em determinado ambiente, não conseguem estabelecer uma relação de sentido. Isso está bem demarcado nas relações de trabalho, que constitui o mote desta pesquisa. Observa-se que, do ponto de vista social, as relações de trabalho desencadearam conflitos pela busca da equidade. Sob a óptica econômica, a construção de sentido apóia-se na utilidade do bem (utilitarismo). E aqui remete-se à questão desenvolvida no início: ambos os critérios são fruto da razão humana e visam à compreensão e à orientação da ação humana. Há algum mais "verdadeiro" que o outro? Nota-se que admitir a preponderância de um sobre o outro resulta no estabelecimento de uma relação de subordinação que romperia com a integridade interior do sistema "não verdadeiro". Em outros termos, como interagir Direito e Economia - duas construções racionais, com pressupostos de partida díspares - , de sorte que a confluência não promova a sobreposição de um ao outro? Cabe, ademais, questionar se, no âmbito das relações de trabalho subordinado, a ideia de consciência individual estaria restrita à figura do empregador, dado que as conquistas dos trabalhadores são atribuídas à consciência da coletividade. Como o sistema econômico (empregador) interage com o psicológico (consciência do trabalhador)?

A proposta restringe-se a observar o contexto sócio-econômico em que incide, imerge e interage o sistema jurídico trabalhista, qual seja: a ética do capital e sua linguagem; a afirmação do trabalhador como ser humano no ambiente de trabalho; a construção da "mente coletiva", as entidades sindicais, o seu papel e o problema da representatividade. Após a análise da estrutura e organização desses subsistemas, volta-se o estudo à dimensão dos impactos desses subsistemas no sistema jurídico e vice-versa, focalizando a atividade fiscalizatória empreendida pela Administração Pública Direta, seus meios de coerção no exercício do poder de polícia, em direta relação com as estruturas e a organização dos subsistemas econômico, psicológico e social.

A importância do pensamento sistêmico/complexo é fundamental para analisar a sociedade plural e pautada por interesses conflitantes. Na seara da complexidade, há margem para o incerto, que não significa o arbitrário. Por incerteza entende-se a ausência de um saber único, mas admite-se o contingente. Há um contexto a ser traçado, elementos a serem identificados, padrões de organização para compreender, enfim, estruturas que não são rígidas, e sim dinâmicas, abertas às pressões externas e capazes de se adaptar sem que suas bases sejam rompidas. O Direito do Trabalho representa um exemplo de adaptação do sistema jurídico, moldado sob o paradigma cartesiano (crença na razão), ao assimilar a 
instabilidade gerada em um cenário de falta de cooperação. Enfim, questiona-se como o abalo na crença na razão humana interfere nas estruturas de poder das relações de trabalho subordinado.

Uma vez que o Direito na modernidade partiu da premissa do homem racional (liberdade de consciência) e estruturou-se com adaptação dos pressupostos econômicoliberais, na medida em que a realidade econômica gerou instabilidade no sistema social, o Direito assume sua função de interferir em comportamentos, por meio de mecanismos "interventivos de cooperação", ou seja, criou um paradoxo. Repropõe-se a ideia de liberdade, a partir do sentido da igualdade representado na figura do hipossuficiente. $\mathrm{O}$ sentido de hipossuficiência, no sistema jurídico, remete ao conflito de poder irresistível, incompatível com a noção de democracia. E para a convivência de sistemas capazes de se auto-organizar, é imprescindível que haja democracia. O sentido de democracia implica o de conflito, mas ambos - democracia e conflito - se manifestam em um ambiente em que não há subjugação e opressão, ou seja, negação da diferença.

O terceiro capítulo aborda a dinâmica e os conflitos dos subsistemas a partir do Direito, especificamente pela atuação da função fiscalizatória do fiel cumprimento das normas de proteção ao trabalho pelo Estado. A base central da questão proposta está na imprescindibilidade do direito como estrutura que generaliza de forma congruente as expectativas comportamentais por meio de normas; sem esse balizamento, os homens, como afirma Niklas Luhmann, não podem se orientar entre si, nem podem esperar (ou prever) comportamentos ${ }^{12}$. Por ser um sistema mais abrangente dentro da sociedade, a estrutura jurídica congrega elementos que alicerçam o meio social e as questões que persistem são: há

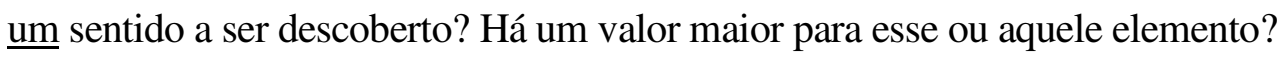

Por isso, indaga-se no último capítulo se é possível se conduzir a um consenso sobre a dignidade humana, em que predomine a efetividade dos direitos fundamentais, ou se o predomínio do dissenso seria inevitável, quiçá até mesmo essencial, em face de uma sociedade pluralista, pela qual perpassam várias formas de poder amparadas por bases referenciais distintas e incomunicáveis. Discutir-se-á a possibilidade de encontrar a verdade e estabelecer conceitos absolutos capazes de orientar o agir humano. Em tempos de crítica à ordem jurídica trabalhista e à indeterminação de conceitos jurídicos como

\footnotetext{
${ }^{12}$ LUHMANN, Niklas. Sociologia do direito I. Trad. Gustavo Bayer. Rio de Janeiro: Edições Tempo Brasileiro, 1983. p. 170.
} 
“dignidade”, indaga-se se a proteção à saúde e à vida do empregado depende de elementos mensuráveis ou empiricamente verificáveis ou o sentido da saúde é um construído com base em dados contingenciais. Essa questão reflete diretamente no âmbito dos acidentes e das doenças de trabalho. A caracterização desses eventos - doença e acidente de trabalho depende do denominado nexo causal entre a atividade laboral e o infortúnio. A construção dos institutos baseou-se em postulados empíricos, isto é, a exposição do trabalhador a agentes físicos, químicos e biológicos. Porém, a relação de causa e efeito objetivamente identificável mostra-se insuficiente para determinar danos provocados pela organização do trabalho tecnologicamente estruturada. Quando a lógica é de reparação metricamente calculada, corre-se o risco de desprezar a importância do sentido humano atribuído ao trabalho. As relações de trabalho subordinado envolvem muito mais do que o meio ambiente física, biológica e quimicamente considerado, mas compreendem as interações entre os indivíduos e suas expectativas no ambiente social.

A exposição sobre "a busca de um consenso da dignidade humana" não se encaminha para a investigação de uma eventual "concepção generalizadora" acerca da dignidade humana, tampouco tenciona exaurir as várias possibilidades de debate sobre a questão. Reduz-se a promover uma investigação sobre o processo de interpretação da dignidade do trabalhador e a sua efetividade e a destacar as bases de referência a serem contempladas, com vistas à manutenção dos alicerces do sistema juslaboral.

A noção de dignidade reforça o dilema que persiste na indeterminação do texto constitucional e na importância dessa indeterminação em face da impermanência e da complexidade pós(ou hiper)-modernas. Enfim, questiona-se: há uma certeza absoluta a ser alcançada ou, a partir da incerteza, constrói-se contingencialmente a realidade?

Em linhas gerais, eis as principais questões e suas delimitações: qual a base referencial extraída do ordenamento jurídico para apreciação da dignidade humana; epistemologicamente, como o Direito do Trabalho pode ser apreciado a partir do pensamento sistêmico; como se apresentam empregados, empregadores e Estado em sua função fiscalizatória, no contexto das relações de trabalho subordinado; diante da organização e estrutura dos subsistemas presentes nas relações de trabalho subordinado, há um sentido a ser atribuído à dignidade do trabalhador, a fim de evitar distorções e rupturas sistêmicas, no momento do cotejo da norma jurídica com as demais variáveis presentes em uma sociedade pluralista. Destaca-se, todavia, que não há a pretensão de esgotar as 
infinitas discussões e variáveis que envolvem o tema e as questões que dele se depreendem.

Enfim, o tema da tese proposta encaminha-se por um raciocínio linear: reconhecer a complexidade do mundo do trabalho para situar a dignidade humana como elemento estruturante do sistema juslaboral.

\section{Metodologia e técnicas de pesquisa}

Foi realizada uma pesquisa de caráter documental (análise de casos judiciais e de dados estatísticos disponibilizados por entidades governamentais e não governamentais) e bibliográfico. Esse critério foi utilizado considerando a necessidade de fomentar o debate sobre o sentido da dignidade, dada a complexidade presente no interior das relações de trabalho subordinado.

Para tanto, valeu-se do método dialético, o qual, a partir da crítica da realidade existente e da evidência de contradições, visa discutir soluções para os problemas e à transformação do quadro estudado.

O método comparativo permitiu identificar as peculiaridades dos subsistemas presentes nas relações de trabalho subordinado, atendendo à finalidade da pesquisa de tentar explicar os fatores e as características que parametrizam tais subsistemas. Ao mesmo tempo, buscou-se explorar novos elementos para a compreensão da dinâmica de poder presente na estrutura das relações de trabalho subordinado - a exemplo do impacto das novas formas de organização de trabalho -, a fim de conferir maior proximidade com o tema e fomentar hipóteses para aprimoramento de conceitos.

Quanto às técnicas de pesquisa, foram utilizadas a consulta de fontes primárias (pesquisa documental: tratados internacionais, legislações nacionais, sentenças judiciais, dados estatísticos etc.) e a consulta de fontes secundárias (pesquisa bibliográfica). A pesquisa assume natureza qualitativa, na medida em que objetiva questionar as premissas que se encontram por trás da concepção de dignidade, conforme os referenciais dos empregados e dos empregadores, além de pontuar o papel da Auditoria-Fiscal do Trabalho, como representante do Estado e dedicada à defesa do sistema normativo de proteção ao trabalho. A partir desse questionamento, almeja-se estimular a discussão sobre novas teorias e conceitos relativos às relações de trabalho subordinado. 


\section{CAPÍTULO I. O MUNDO DO TRABALHO E O SISTEMA JUSLABORAL: A COMPLEXIDADE REAL E A BUSCA DO MODELO IDEAL}

\section{O pensamento científico: da crença no mito à crença na razão}

Em "A Grande Transformação - as origens da nossa época”, Karl Polanyi inicia o primeiro capítulo com a seguinte premissa: "A civilização do século XIX ruiu". ${ }^{13}$ Dessa assertiva pungente extrai-se, conforme o autor desenvolverá ao longo de sua obra, o questionamento sobre a sustentação dos alicerces e das soluções que formataram uma nova concepção de sociedade: as premissas da modernidade. Para os fins deste estudo, torna-se imperioso reformular a premissa de Polanyi: o paradigma sócio-econômico e político do século XIX não apenas ruiu, mas especialmente exibiu suas contradições.

Por paradigma adota-se o conceito formulado por Thomas S. Kuhn: "Considero 'paradigmas' as realizações científicas universalmente reconhecidas que, durante algum tempo, fornecem problemas e soluções modelares para uma comunidade de praticantes de uma ciência". ${ }^{14}$

O modelo de sociedade do século XIX, a que se refere Karl Polanyi, é resultado de uma trajetória histórica iniciada no século XVI. E. K. Hunt destaca que, após 1500, as mudanças econômicas e sociais começaram a ocorrer com frequência, cada uma reforçando a anterior, e todas conduzindo ao capitalismo. ${ }^{15} \mathrm{E}$ as descobertas científicas contribuíram para a afirmação das premissas do desenvolvimento capitalista, ao inaugurar

\footnotetext{
${ }^{13}$ POLANYI, Karl. A grande transformação: as origens da nossa época. Trad. Fanny Wrobel. 2. ed. Rio de Janeiro: Elsevier, 2000. p. 17.

${ }^{14}$ KUHN, Thomas S. A estrutura das revoluções científicas. Trad. José Ricardo Brandão Azevedo e Ma. José Cyhlar Monteiro. São Paulo: Perspectiva, 2007. p. 13. A ciência, do ponto de vista histórico, é um fenômeno da sociedade e Thomas Kuhn, ao introduzir a noção de matriz disciplinar ou paradigma, aceita que "a pesquisa científica é influenciada pelo ponto de partida, suas 'lentes', seus preconceitos, seus projetos subjacentes etc. Aqui, a sociologia - ou história da ciência - começa a considerar como os elementos sociais podem estruturar o conhecimento científico". (FOUREZ, Gérard. A construção das ciências: introdução à filosofia e à ética das ciências. Trad. Luiz Paulo Rouanet. São Paulo: Ed. UNESP, 1995. p. 170-171).

${ }^{15}$ HUNT, E. K. História do pensamento econômico: uma perspectiva crítica. Trad. Beatriz Vianna Boeira e Nelson Boeira. 2. ed. Rio de Janeiro: Elsevier, 2005. p. 14.
} 
a crença na razão humana como fonte de resolução de questões, a partir dos métodos científicos de análise do mundo fático.

Com o advento do progresso tecno-científico, o grande desafio foi promover a ruptura com os valores éticos da antiguidade, ou seja, superar esse paradigma anterior. Como escreve Thomas Kuhn, a mola propulsora das mudanças nas ciências é um sentimento "de que o paradigma existente deixou de funcionar adequadamente na exploração de um aspecto da natureza, cuja exploração fora anteriormente dirigida pelo paradigma". E continua o autor: "Tanto no desenvolvimento político como no científico, o sentimento de funcionamento defeituoso, que pode levar à crise, é um pré-requisito para a revolução". 16

Contudo, a estrutura edificada pelo paradigma anterior não é substituída inexorável e definitivamente. Ao contrário, estimula e fundamenta em si a mudança a ser perpetrada. Explica-se: a antiguidade baseou-se na crença no mito; a modernidade inspirou-se na crença na razão. Ou seja, a inspiração metafísica não foi suplantada pelo advento das técnicas científicas que tentaram desmerecê-la, mas permitiu a mudança do foco: do transcendental para o material.

Um grande problema resultante dessa transformação repousa no questionamento das bases axiológicas que formatam os alicerces do modelo paradigmático adotado. A redução da razão ao tecnicismo e ao cientificismo levou, como aponta Giovanni Reale, à communis opinio “de que só é 'verdadeiro' aquilo que pode ser demonstrado com base em cálculos matemáticos e comprovado segundo os cânones 'da experiência', ou seja, os das ciências experimentais." 17

A concepção do homem e da sua posição no mundo conformou-se à visão científico-tecnológica de organização. E, como será analisado, a tecnologia interferiu diretamente nas relações de trabalho, em formas de organização tayloristas, fordistas e toyotistas.

Mas antes de percorrer pelas consequências advindas do paradigma técnicocientífico, é fundamental discorrer acerca das bases sobre as quais se operaram as

\footnotetext{
${ }^{16}$ KUHN, Thomas. op. cit., p. 126.

${ }^{17}$ REALE, Giovanni. O saber dos antigos: terapia para os tempos atuais. 2. ed. Trad. Silvana Corbucci Leite. São Paulo: Ed. Loyola, 2002. p. 35. Também observa Maria José Esteves de Vasconcellos, "o conhecimento científico se edifica em torno da matemática. (...) Costuma-se dizer que o nosso paradigma de ciência é o paradigma newtoniano do mundo como máquina" (VASCONCELLOS, Maria José Esteves de. Pensamento sistêmico: o novo paradigma da ciência. 7. ed. Campinas: Papirus, 2002. p. 62).
} 
mudanças de concepção de homem no mundo e, especialmente, dos seus valores. E aqui desponta o foco da transformação: a Física.

\subsection{A presença do mito: da hybris à physis}

Como esclarece Fritjof Capra, o termo Física deriva da palavra grega physis, cujo significado original é "a tentativa de ver a natureza essencial de todas as coisas" ${ }^{18}$. Como as coisas no mundo não são permanentes, inalteráveis, o conceito de physis para os antigos gregos caracterizava-se pela ideia de dinamicidade profunda e genética ${ }^{19}$ : "Etimologicamente, physis é um abstrato formado pelo sufixo sis e pela raiz verbal phy; na voz ativa: phúein, na voz média: phúesthai. (...) Na voz ativa significa produzir (como o bosque na primavera produz folhas), e na voz média significa crescer". ${ }^{20}$

A physis, ademais, compreendia não somente o universo material, visível e palpável, mas o psíquico, o anímico ou o espiritual. E, por isso, “esta importante dimensão da physis pode ser melhor compreendida a partir de sua gênese mitológica". ${ }^{21}$

Etimologicamente, mythos significa palavra, enredo, fala e, ao possuir relação com o conceito de expressão, traduz, em última instância, a "percepção que o humano tem das coisas, ou seja, a imposição de estruturas dramáticas ao fluxo e ao caos da natureza". ${ }^{22}$ [grifo nosso] É por meio do mito que se "cria uma ponte entre o desconhecido e o conhecedor e ajuda o ser humano a colocar-se em alguma espécie de relação de significado com o mistério". 23

Na mitologia grega, a imagem do divino aproxima-se à do mortal, física e psicologicamente. ${ }^{24}$ Os deuses não correspondem a entidades sobrenaturais, uma vez que

\footnotetext{
${ }^{18}$ CAPRA, Fritjof. O Tao da Física: um paralelo entre a física moderna e o misticismo oriental. Trad. José Fernandes Dias. 21. ed. São Paulo: Cultrix, 2002. p. 23.

${ }^{19}$ BORNHEIM, Gerd A. (Org.). Os filósofos pré-socráticos. 12. ed. São Paulo: Cultrix, 2003. p. 12.

${ }^{20}$ Id. Ibid., p. 11.

${ }^{21}$ Id. Ibid., p. 12.

${ }^{22}$ HOLLIS, James. Rastreando os deuses: o lugar do mito na vida moderna. Trad. Maria Silvia Mourão Netto. São Paulo: Paulus, 1997. p. 10-11.

${ }^{23}$ Id. Ibid., p. 11.

24، Os gregos deram aos deuses a forma humana, e Fídias explicou o motivo de tal procedimento, dizendo: 'Se damos aos deuses a forma humana é por desconhecermos forma mais perfeita"'. (MÉNARD, René. Mitologia greco-romana. Trad. Aldo Della Nina. São Paulo: Opus, 1991. v. 1, p. 5).
} 
eles integram a própria natureza. ${ }^{25}$ Têm paixões, buscam vingança, têm interesses e, portanto, atribuem valor às coisas, assim como os homens. No entanto, os deuses mitológicos são evidentemente superiores aos mortais. E essa premissa deve orientar a conduta dos mortais, sob pena de sua degeneração.

Como os deuses simbolizam as forças cósmicas ${ }^{26}$, interferir ou se imaginar capaz de afrontá-los significa romper com o ciclo de ordem e caos que mantém a possibilidade de existência. Aliás, o mito de Hefestos mostra que mesmo os deuses devem se curvar ao ciclo da natureza.

Deus do fogo, Hefestos (ou Vulcano) nasceu da união entre Zeus e Hera, a qual, inconformada com a imperfeição do filho - feio e coxo -, atirou-o do Olimpo. Após um dia em queda, caiu na ilha de Lemnos, onde um anão lhe ensinou a arte de trabalhar o ferro , o bronze e os metais preciosos. Hefestos é o divino trabalhador e, segundo a mitologia, modelou a primeira mulher: Pandora. Como aponta Felipe Pena, Hefestos é um deus ambíguo: em contato permanente com a beleza - casado com a deusa Afrodite e capaz de criar belíssimas obras -, "sua própria aparência é horripilante" e "ele não consegue usar a habilidade para mudar a si mesmo, ou seja, apesar de dominar a tecnologia, a natureza ainda continuará impondo-lhe limites". ${ }^{27}$

Nota-se que os mitos vão além da narrativa da "origem do Mundo, dos animais, das plantas e do homem", mas relatam "todos os acontecimentos primordiais em consequência dos quais o homem se converteu no que é hoje - um ser mortal, sexuado, organizado em sociedade, obrigado a trabalhar para viver, e trabalhando de acordo com determinadas regras". ${ }^{28}$ [grifo nosso]

\footnotetext{
${ }^{25}$ BORNHEIM, Gerd A. (Org.). op. cit., p. 12.

${ }^{26}$ “Tudo quanto nos apresenta a natureza exterior era, aos olhos dos antigos, a forma visível de personalidades divinas. A terra, o céu, o sol, os astros, as montanhas, os vulcões, os tremores de terra, os rios, os regatos, as árvores, eram personagens divinas, cuja história os poetas narravam, e cuja imagem fixavam os escultores. Mas a alegoria não era absolutamente uma forma particular à arte, pois fazia também parte da linguagem usual. Algumas expressões mitológicas passaram para a nossa moderna linguagem. Por exemplo, dizemos: o sol deita-se; e, no entanto, sabemos que não se despe e não se estende no leito; trata-se apenas de uma forma alegórica admitida pelo hábito”. (MÉNARD, René. op. cit., p. 1-2).

${ }^{27}$ PENA, Felipe. A perna coxa da tecnologia: fantasias totalitárias dos náufragos da polissemia na cibercultura. Revista Contracampo, Rio de Janeiro, v. 9, n. 0, p. 143, 2005. Disponivel em: $<$ http://www.revistas.univerciencia.org/index.php/contracampo/article/view/26/25>. Acesso em: 17 jan. 2010.

${ }^{28}$ ELIADE, Mircea. Mito e realidade. Trad. Póla Civelli. São Paulo: Perspectiva, 2007. p. 16. (Col. Debates, n. 52).
} 
Os deuses mitológicos não se arvoram na condição de seres perfeitos, ao contrário, expressam sentimentos humanos. No caso específico de Hefestos, desprovido de beleza e força físicas, a sua importância reside na utilidade de seus trabalhos para os demais deuses. Segundo narra René Ménard, como vingança pela rejeição dos pais, Hefestos criou uma cadeira e, quem nela se sentasse, somente conseguiria levantar após permissão dele, Hefestos. Sua própria mãe, Hera, foi a vítima da armadilha e, após violento ataque de Ares, Hefestos liberou sua mãe, não sem ressentimento e decidido a não retornar ao Olimpo. Afligidos com a hipótese de se privarem da magnífica habilidade de Hefestos, Dioniso consegue reconciliar o deus ferreiro com os outros imortais. ${ }^{29}$ Extrai-se que Hefestos é admitido no Olimpo porque os deuses apreciam a sua arte (utilidade, técnica). Contudo, ao conferir a importância à utilidade - à técnica - , descuida-se da essência do deus do fogo, a qual, como pondera Felipe Pena, é a representação mitológica da tecnologia: ambígua e limitada. ${ }^{30}$ Assim como o deus mitológico, a tecnologia está fadada a se submeter aos limites impostos pelo ciclo da natureza. E essa afirmação contraria todo o cenário dos tempos atuais, em que duas máximas imperam: "tudo é possível” e "nada é certo".

Uma das questões exploradas pela mitologia greco-clássica é a necessidade de o homem conhecer os limites de suas ações, para não ser impulsionado pela força arrebatadora da hybris.

Lídia Reis de Almeida Prado esclarece que hybris, para os gregos, significava "tudo o que ultrapassa a medida (démesure), excesso, descomedimento, sendo considerado por Hesíodo a maior inimiga da Justiça (Diké)." ${ }^{31}$ Enfim, hybris é "o não reconhecer o que é humano e o que é divino",32, ou seja, é ultrapassar as fronteiras do que é humano.

A hybris afasta a noção de limite ao ameaçar até mesmo a própria existência biológica. Dilacerado pela arrogância, o homem esquece-se da sua condição humana e pode avançar no cometimento de ações que culminam na destruição de si mesmo. Saber dominar a hybris é um dos maiores desafios da humanidade e a História comprova essa assertiva.

\footnotetext{
${ }^{29}$ MÉNARD, René. op. cit., v. 2, p. 140-141.

${ }^{30}$ PENA, Felipe. op. cit., p. 144.

${ }^{31}$ PRADO, Lídia Reis de Almeida. O juiz e a emoção: aspectos da lógica formal. 4. ed. Campinas: Millennium, 2008. p. 207.

${ }^{32}$ HOLLIS, James. op. cit., p. 45.
} 
Como a hybris é uma força, a sua manifestação encontra-se atrelada ao exercício do poder. Quem detém o poder, está mais próximo da hybris. E essa afirmação contribui para o entendimento do fim do regime absolutista e da constituição do Estado de Direito. Vale recordar a célebre frase de Maria Antonieta, em meio à miséria e ao clamor do povo francês que reclamava por pão: "Não têm pão? Comam brioches!".

Observa-se que a noção de hybris traz em seu bojo o conteúdo ético, porque as ações realizadas sob seu domínio passam por um crivo de valores. Seriam esses valores determinados, realmente, pela ética ou derivariam dos parâmetros traçados nas relações de poder na sociedade? Cabe, então, a dúvida suscitada por Ernst Tugendhat:

É o ético, ou então, ao contrário, as relações de poder, que são determinantes na vida social? E essas não determinam, por sua vez, as representações éticas de um tempo? E se isto é assim, ao se pretender lidar diretamente com a ética e não a partir de uma perspectiva crítica da ideologia, não representaria isto um retorno a uma ingenuidade hoje insustentável? ${ }^{33}$

O próprio autor reduz suas indagações a uma questão fundamental: "se existe compreensibilidade de normas morais que seja independente de tradições religiosas". ${ }^{34}$ Ou seja, existe uma moral moderna ou, quiçá, várias morais modernas. Ao propor essa reflexão, Ernst Tugendhat lembra que a coexistência de várias morais contradiria a pretensão de validade universal atribuída às normas morais e, a partir de uma análise da obra de Nietzsche, o autor conclui que: depois que a fundamentação religiosa foi rejeitada, a moral acabou. ${ }^{35}$

O abandono da mitologia inicia uma etapa da humanidade em busca de respostas a partir das suas experiências:

Há quem argumente que o espírito modernista começa com algumas ideias gregas clássicas, como a tentativa dos pré-socráticos de encontrar uma metafísica não-teológica, com a articulação do método científico por Bacon, com a cisão mente-corpo difundida por Descartes no século XVII, ou o reconhecimento explicitado por Kant de categorias a priori do pensamento como a natureza constitutiva da Natureza, no final do século XVIII. ${ }^{36}$

\footnotetext{
${ }^{33}$ TUGENDHAT, Ernst. Lições sobre ética. Trad. Robson Ramos dos Reis. 5. ed. Petrópolis: Vozes, 2003. p. 11.

${ }^{34}$ Id. Ibid., p. 13.

${ }^{35}$ Id. Ibid., p. 14.

${ }^{36}$ HOLLIS, James. op. cit., p. 45.
} 
São os pré-socráticos que rompem com a tradição mitológica e atribuem à physis o sentido mais próximo da ideia de investigação, de busca de fundamento para a compreensão da vida. A physis seria o imaterial que comanda e dá unidade ao todo.

\subsection{Sofistas: o princípio da impermanência e da incerteza}

O nascedouro da filosofia dá-se no século $\mathrm{V}$ a. C., na Ásia e na Grécia, “substituindo-se, pela primeira vez na História, o saber mitológico da tradição pelo saber lógico da razão. O indivíduo ousa exercer a sua faculdade de crítica racional da realidade". 37

Ao propor a superação do mito e a introdução da physis, os pré-socráticos buscavam "aquilo que por si brota, se abre, emerge, o desabrochar que surge de si próprio e se manifesta neste desdobramento, pondo-se no manifesto" ${ }^{38}$ : "Vale dizer que na base do conceito de physis não está a nossa experiência da natureza, pois a physis possibilita ao homem uma experiência totalmente outra que não a que nós temos frente à natureza”. ${ }^{39}$

Nota-se que a physis abarca tanto o mundo material quanto o psíquico. Portanto, distingue-se da noção de física hodiernamente adotada, a qual está associada à natureza material. Passa-se, então, a traçar um breve perfil do pensamento de quatro filósofos présocráticos: Tales de Mileto, Heráclito de Éfeso, Parmênides e Demócrito de Abdera.

Tales de Mileto foi considerado por Aristóteles como o fundador da filosofia. Destacam-se duas ideias centrais em seu pensamento: a) a afirmação de que a terra repousa sobre a água, razão pela qual seria o princípio de todas as coisas; b) e a célebre frase a ele atribuída: "todas as coisas estão cheias de deuses".

A água, para Tales de Mileto, é a arké, isto é, o princípio de tudo aquilo que vem a $\operatorname{ser}^{40}$. Para se manter vivo, o ser nutre-se daquilo que o originou; se o que morre seca, a água é essencial para o ser e, portanto, é o princípio. Dessa conclusão, é possível extrair

\footnotetext{
${ }^{37}$ COMPARATO, Fábio Konder. Ética: direito, moral e religião no mundo moderno. São Paulo: Companhia das Letras, 2006. p. 38.

${ }^{38}$ BORNHEIM, Gerd A. (Org.). op. cit., p. 12.

${ }^{39}$ Id. Ibid., p. 14.

${ }^{40}$ Id. Ibid., p. 12.
} 
que a existência do ser depende da sua relação harmônica com a sua essência. E a isso soma-se a máxima creditada a Tales: "todas as coisas estão cheias de deuses".

Em uma abordagem literal e descontextualizada da época em que foi anunciada, a frase traduziria um caráter religioso, contrastante com a proposta de promover o conhecimento do mundo sob a inspiração humana e não divina. Contudo, ainda que seja impossível situar-se precisamente no contexto pré-socrático, não é desarrazoado admitir que a inspiração humana nesse período do pensamento grego não descartava o anímico. Destarte, os "deuses" encerram "as misteriosas forças vivas", de sorte que "a distinção entre a natureza animada e inanimada não tem fundamento algum" ${ }^{41}$. Enfim, o material e o psíquico participam na compreensão do universo.

O princípio da impermanência está classicamente retratado nos fragmentos de Heráclito de Éfeso, sendo um dos mais conhecidos o de número 91: "91. Não se pode entrar duas vezes no mesmo rio. Dispersa-se e reúne-se; avança e se retira." ${ }^{, 2}$

Muito mais que afirmar a instabilidade das coisas, Heráclito situa o homem como parte do Cosmo. Ele estabelece o caráter relacional entre o homem e o universo, o que significa que um não pode ser compreendido sem o outro. Defende a ideia de que a luta dos contrários gera a harmonia, ou seja, o bom não existe sem o mau, o quente sem o frio, o divino sem o profano, o material sem o imaterial. Diante dessa dialética, a experiência sensorial não é suficiente para perscrutar a unidade presente no movimento dos contrários; o conhecimento vem da razão humana: "4. Se a felicidade consistisse nos prazeres do corpo, deveríamos proclamar felizes os bois, quando encontram ervilhas para comer". ${ }^{43}$ A sabedoria consiste em conhecer o pensamento universal, pois Heráclito acreditava em uma lei universal que governa tudo por si mesmo: "44. Só uma coisa é sábia: conhecer o pensamento que governa tudo através de tudo". ${ }^{4}$

A ideia do universal - algo inspirado pelo Logos, Espírito, Pensamento ou Inteligência - torna-se fundamental na construção do sentido do humano. Independentemente das circunstâncias e do contexto, surge com os pré-socráticos a inquietação de descobrir qual seria o pensamento que traduz fenômenos atemporais e o complexo universo humano. Fábio Konder Comparato lembra que as tragédias gregas já

\footnotetext{
${ }^{41}$ BORNHEIM, Gerd A. (Org.). op. cit., p. 13.

${ }^{42}$ HERÁCLITO DE ÉFESO. Fragmentos. In: BORNHEIM, Gerd A. (org). op. cit., p. 41.

${ }^{43}$ Id. Ibid., p. 38.

${ }^{44}$ Id., loc. cit.
} 
representavam, em sua essência, "uma contínua investigação, à luz dos sentimentos universais que a mitologia tão bem ilustra - o orgulho, o ciúme, a vingança, o amor, o ódio - da inestimável complexidade da alma humana", de maneira que "a interpretação dos mitos transmuda-se, gradativamente, de meditação religiosa em discussão racional". ${ }^{\circ}$

Na esteira da valorização do pensamento, Parmênides (aproximadamente de 530 a.C. a 460 a. C.) não faz distinção entre o ser e o ser pensado. Para ele, somente pode ser pensado ou realmente nomeado aquilo que é; somente pode ser o que pode ser pensado ${ }^{46}$. Parmênides propugna a ideia de que o ser é uno, universal, imutável e não gerado. Para esse filósofo, as experiências sensoriais não constituem fonte de conhecimento, porque a realidade sensível é ilusória. Ao analisar o sistema de Parmênides, José Leite Lopes conclui que há um ponto fraco em seus postulados: a rejeição do mundo, da variedade das coisas, uma vez que ele só contempla a ideia do ser único e imutável ${ }^{47}$.

Demócrito de Abdera, diversamente de Heráclito, "explica o universo, os fenômenos e as próprias atividades espirituais pela combinação dos átomos". ${ }^{48}$ Demócrito, portanto, anuncia a vertente materialista como base do conhecimento. O materialismo de Demócrito não se traduz no conhecimento pela experiência sensorial. Mas depreende-se dos fragmentos de Demócrito a advertência de que a certeza é inalcançável; o que se logra atingir é a demonstração da realidade, porém não ela mesma:

9. Em verdade, nada aprendemos que seja infalível, mas somente o que nos vem através da disposição momentânea do nosso corpo e dos (átomos) que nos atingem ou se lhe opõem.

10. Não aprendemos o que, na realidade, cada coisa é ou não é; demonstramos isto diversas vezes. ${ }^{49}$

Desses fragmentos exsurge a indissociabilidade do homem com o objeto de conhecimento; há uma interação entre sujeito-objeto já antecipada nos escritos de Demócrito. Ademais, persiste em Demócrito a esfera do incompreensível, inatingível, pois nada que é humanamente aprendido é infalível. Dessa forma, o conhecimento não é um

\footnotetext{
${ }^{45}$ COMPARATO, Fábio Konder. op. cit., p. 89.

${ }^{46}$ LOPES, José Leite. A imagem física do mundo: de Parmênides a Einstein. Revista de Estudos Avançados. São Paulo, v. 5, n. 12. maio/ago.1991. Disponível em: <http://www.scielo.br/scielo.php?pid=S010340141991000200007\&script=sci_arttext>. Acesso em: 20 ago. 2010.

${ }^{47}$ Id. Ibid.

${ }^{48}$ NOGARE, Pedro Dalle. Humanismos e anti-humanismos: introdução à antropologia filosófica. 10. ed. Petrópolis: Vozes, 1985. p. 28.

${ }^{49}$ DEMÓCRITO DE ABDERA. Fragmentos. In: BORNHEIM, Gerd A. (Org.). op. cit., p. 107.
} 
resultado inquestionável; ele é renovado de acordo com a percepção e com a relação estabelecida com o outro (objeto).

A possibilidade de se atingir a certeza, o objetivo, o estável também foi questionada pelos sofistas. Os sofistas ficaram conhecidos como professores errantes, hábeis na arte da argumentação, mas não escaparam das duras críticas de Platão, entre outras pela prática de cobrar pelos ensinamentos ministrados. Eram criticados também pelo "abuso da dialética com a qual tentavam mostrar que das mesmas premissas se podem deduzir conclusões opostas" ${ }^{50}$, o que resultava em relativismo do conhecimento.

Essa ideia de incerteza, vislumbrada em Demócrito, faz-se mais presente nos sofistas, como produto da importância conferida ao humano. Para Pedro Dalle Nogare, "o grande mérito deles é de ter chamado com insistência a atenção dos sábios para os problemas humanos". ${ }^{51}$ Basta apontar a decantada citação de Protágoras, considerado o sofista mais célebre: "O homem é a medida de todas as coisas, das que são enquanto são e das que não são enquanto não são".

Em princípio, ressalta-se o foco lançado sobre o homem, de maneira que os sofistas se afastaram da especulação acerca da natureza ou do princípio/realidade suprema ${ }^{52}$. Isso se explica pela certeza de que não alcançaria a verdade absoluta. Entre o prevalecimento das leis (phýsis) e o prevalecimento da arbitrariedade das leis (nómos), Eduardo Bittar explica que os sofistas optaram, em geral, pela segunda hipótese, uma vez que "diziam ser o homem o princípio e a causa de si mesmo, e não a natureza"53.

A proposição de Protágoras instiga a reflexão acerca do valor das coisas. $\mathrm{Na}$ ausência de um ideal de absoluto e objetivo, isto é, a partir do relativismo que caracteriza os sofistas, caberiam duas interpretações para a frase: a) dada a relatividade das coisas, cada homem individualmente considerado confere às coisas a medida (valor), conforme seu entendimento; b) o homem é o padrão de referência (metron) para estabelecer o valor das coisas, uma vez que as coisas estão subordinadas ao homem e não o contrário.

A primeira interpretação leva ao individualismo extremo, ao estabelecer que as preferências e as escolhas são fruto do entendimento particular. Por outro lado, a segunda

\footnotetext{
${ }^{50}$ NOGARE, Pedro Dalle. op. cit., p. 30.

${ }^{51}$ Id., loc. cit.

${ }^{52}$ LUCE, J.V. Curso de filosofia grega: do séc. VI a.C. ao séc. III d.C. Trad. Mário da Gama Kury. Rio de Janeiro: Jorge Zahar, 1994. p. 84.

${ }^{53}$ BITTAR, Eduardo; ALMEIDA, Guilherme Assis de. Curso de filosofia do direito. 4. ed. São Paulo: Ed. Atlas, 2005. p. 61.
} 
traça parâmetros que permitem delinear o caráter humanista atribuído aos sofistas: o valor do que "é" e do que "não é" deriva da posição do homem em face das coisas; é o metron entre o homem e as coisas.

Protágoras também distingue educação técnica da educação humanista e "observa que se a capacidade técnica do homem distancia imensamente o homem dos animais e lhe proporciona meios de defesa, dos quais os animais são equiparados pela natureza, ela não basta para a convivência humana". 54

Mantidas as devidas cautelas e ressalvas quanto ao contexto histórico, depreendemse dos ensinamentos dos sofistas elementos inspiradores para os direitos humanos da modernidade. Mas tal fato não deixa de ser curioso quando se observa que a palavra "sofista" assumiu um significado pejorativo, atribuído àquele (a) que de premissas verdadeiras chega a conclusões falsas.

Se os sofistas devotam seu pensamento ao humano, Sócrates e Platão completam o mergulho no universo do homem.

\subsection{O pensamento platônico e o reconhecimento de um mundo ideal}

Conforme visto, a filosofia ocupava-se com o mundo material (physis), enquanto à mitologia cabia perscrutar o mundo alheio à matéria perecível e marcada pelo ritmo da incerteza. O imutável consistia no elemento de formação do universo mitológico. Em um contexto de questionamento sobre a origem das coisas materiais, não haveria, então, mais espaço para o mito. No entanto, o mito não desaparece do universo do homem.

A fronteira entre mitologia e filosofia nunca foi absoluta. Ao tratar de questões cujo entendimento era de difícil alcance, Platão valeu-se do método de explicação mitológica, ou seja, utilizou-se de alegorias e simbolismos. Exemplo clássico é o mito da caverna, narrado em $A$ República. ${ }^{55}$ Aliás, a crítica socrática, conforme ressalta Fábio Konder Comparato, "não se dirigia diretamente à religião, e sim aos relatos mitológicos". 56 O foco do questionamento era direcionado ao fato de os mitos submeterem todo e qualquer ato à

\footnotetext{
${ }^{54}$ NOGARE, Pedro Dalle. op. cit., p. 32.

${ }^{55}$ COMPARATO, Fábio Konder. op. cit., p. 87.

${ }^{56}$ Id. Ibid., p. 89.
} 
vontade dos deuses, a ponto de a felicidade humana constituir um capricho dos deuses. ${ }^{57}$ Não era incompatível a ideia de permanência e de imutabilidade com a investigação sobre a natureza dos seres; pelo contrário, essa ideia é reforçada pelo pensamento platônico. Em Platão, fortalece-se a realidade imutável, conhecido por "Mundo das Ideias".

A partir dessa ruptura entre seres materiais e ideias imutáveis, a própria concepção de homem passa a ser redimensionada. O destino e a felicidade humanas não repousariam mais nas mãos de deuses situados em um mundo acima do plano material. Maria Chiara Pievatolo relata que já ao final do século $\mathrm{V}$ os gregos começaram a falar de sua psyché como se possuísse identidade ou personalidade autônoma, e não fosse apenas fragmento de um fluir cósmico-vital. A psyché, segundo a referida autora, é para os gregos o espírito que pensa e é capaz de decisões morais e de, por meio da ciência, ampliar seu conhecimento. $\mathrm{O}$ sujeito conhecedor é um eu autônomo. ${ }^{58}$ Nesse cenário, não há mais espaço para a mimesis, ou seja, para imitação ou mesmo identificação com os relatos das tradicionais temáticas mitológicas. A falta de espaço para mimesis embasou a crítica formulada por Sócrates, contrária à tradição dos mitos.

Para sustentar a crítica de Sócrates, o homem deixa de se identificar com a tradição e se converte em um objeto também passível de estudo. O homem cria-se e transforma-se (poeisis) e, nessa busca, empreende seus esforços para encontrar a Verdade, que não é ensinada, mas aprendida e apreendida pela experiência pessoal de cada um. Ou seja, há modelos imutáveis das virtudes e dos valores, no entanto eles não são reproduzidos no mundo material; concentram-se no Mundo das Ideias.

O mito da caverna é o recurso utilizado por Platão para esclarecer como a Verdade se oculta e o modo de vislumbrá-la. E o mito é o meio mais adequado para explicitar esse pensamento, porque o Mundo a que se refere Platão não pertence a esfera material; encontra-se no âmbito do imaginário, isto é, no universo que só pode ser alcançado pelo mito. Porém, o relato mitológico de Platão não se confunde com os dilemas e intrigas de deuses olímpicos. No mito da caverna, há a descoberta e transformação da capacidade de ver e conhecer do homem, a partir do reconhecimento do mundo ideal. O encontro do mundo humano com o mundo das ideias, frisa-se, é uma experiência pessoal e um reconhecimento. Para Sócrates, o aprendizado nada mais seria que uma reminiscência ou

\footnotetext{
${ }^{57}$ COMPARATO, Fábio Konder. op. cit., p. 89.

${ }^{58}$ PIETAVOLO, Maria Chiara. I padroni del discorso: Platone e la liberta della conoscenza. Pisa: Ed. Plus, 2003. p. 84.
} 
anamnesis, ou seja, um chamado à mente de coisas que já eram conhecidas. ${ }^{59}$ A parte que resgata esse conhecimento é a psyché, qual seja, a parte imaterial que constitui o ser humano. A afirmação da natureza da psyché (imaterial e imortal) conduz a uma abordagem do ser humano que ultrapassa a matéria, o objetivo e o metódico.

Maria Chiara Pietavolo cita que o marxista Ernst Bloch se contrapôs a anamnesis, considerando-a como qualquer coisa que, em razão da sua atemporalidade, não poderia evoluir e constitui, portanto, um factum, algo reificado e mercantilizado. Todavia, contrária a esse entendimento, a autora destaca que a noção de anamnesis não permite sustentar que uma ideia possa ser objeto de propriedade, "porque a pesquisa e o aprendizado podem ter lugar somente como pressuposto de um continuum de conhecimento contextual comum e interconexo (...) ${ }^{60}$. A virtude não pode ser aprendida, porque não pode ser ensinada.

Quando se busca enquadrar o homem no processo de conhecimento, o confronto entre o pensamento platônico com a sofística, de acordo com Maria Chiara Pietavolo, resulta em dois modelos de conhecimento contrapostos e concorrentes:

Se entendemos o conhecimento, em relação a quem conhece, como qualquer coisa de exterior, patrimonial, mecanicamente transferível, objeto de compra-e-venda, os motivos da validade cognitiva se mesclam aos interesses comerciais e competitivos; a comunicação resulta monológica e limitada à atuação de tais interesses (...). Se entendemos o conhecimento como qualquer coisa de interior em relação a quem conhece - qualquer coisa que modifica a vida - teremos ao contrário um conhecimento pessoal (...) as coisas nesses termos não são possuídas como as páginas de um receituário, mas são nossas enquanto buscamos discutir sua posição nas relações com todos e com tudo. ${ }^{61}$

Da mesma maneira, em Platão, a felicidade não comporta um modelo único; a polis grega, como espaço público de reunião dos cidadãos gregos, não se ocupa com um projeto de "bem-estar do indivíduo". Ao contrário, Platão admite uma pluralidade de paradigmas possíveis, pois há diversas felicidades, moduladas pelos diversos interesses identificáveis na sociedade ${ }^{62}$. Sendo assim, um agricultor constrói sua hierarquia de valores, da mesma forma que o comerciante também estabelece a sua escala de preferências. Porém, esses valores não seriam apriorísticos, pois originar-se-iam da discussão da posição de cada qual na interação com os demais semelhantes e com o todo social.

\footnotetext{
${ }^{59}$ PIETAVOLO, Maria Chiara. op. cit., p. 102.

${ }^{60}$ Id. Ibid., p. 103.

${ }^{61}$ Id. Ibid., p. 99-100.

${ }^{62}$ Id. Ibid., p. 184.
} 
Mas no que consiste o homem? Qual é a sua natureza? Ernst Cassirer explica que, ao ultrapassar o limite do físico, do material, os diálogos socráticos de Platão apontam para a natureza das qualidades e virtudes humanas individuais, entretanto sem apresentar uma definição do homem ${ }^{63}$. A justificativa socrática para essa omissão é decifrada por Cassirer: o homem não pode ser descrito como os objetos materiais, as coisas físicas; "o homem só pode ser descrito e definido nos termos de sua consciência" ${ }^{64}$. Por isso, Sócrates, na interpretação de Cassirer, conclama ao conhecimento dialético, ou seja, a superação do monólogo intelectual das descobertas individuais de "coisas prontas", para o diálogo entre sujeitos em cooperação na busca da verdade, não concebida com um objeto empírico, mas como um ato social. Diante disso, Cassirer formula com base no pensamento socráticodialógico o que seria o homem: "é a criatura que, em todos os momentos de sua existência, deve examinar e escrutinar as condições de sua existência”. E o valor da vida humana consiste nesse incessante escrutínio ${ }^{65}$. Tudo o que é exterior ao homem não afeta sua essência $^{66}$.

Mas a questão da sistematização e da especialização do conhecimento científico é compreendida a partir do pensamento aristotélico. Com Aristóteles, a razão humana assume o papel de organizar o método de conhecimento. Pablo González Casanova destaca que "a primeira grande divisão do trabalho intelectual na cultura do Ocidente apareceu quando Aristóteles escreveu sua obra monumental conhecida como o Organon “ 67 .

Todo esse arcabouço filosófico inspira os renascentistas e, a partir do século XVI, consolida-se o paradigma de conhecimento da modernidade. A esse respeito, escreve Fritjof Capra que:

A visão do mundo e o sistema de valores que estão na base da nossa cultura, e que têm de ser cuidadosamente reexaminados, foram formulados em suas linhas essenciais nos séculos XVI e XVII. Entre 1500 e 1700 houve uma mudança drástica na maneira como as pessoas descreviam o mundo e em todo o seu modo de pensar. ${ }^{68}$

\footnotetext{
${ }^{63}$ CASSIRER, Ernst. Ensaio sobre o homem: introdução a uma filosofia da cultura humana. Trad. Rosa Bueno. São Paulo: Martins Fontes, 2001. p. 15.

${ }^{64}$ Id. Ibid., p. 16.

${ }^{65}$ Id. Ibid., p. 16-17.

${ }^{66}$ Id. Ibid., p. 18.

${ }^{67}$ GONZÁLEZ CASANOVA, Pablo. As novas ciências e as humanidades: da academia à política. Trad. Mouzar Benedito. São Paulo: Ed. Boitempo, 2006. p. 14.

${ }^{68}$ CAPRA, Fritjof. O ponto de mutação: a ciência, a sociedade e a cultura emergente, cit., p. 49.
} 
A transformação repercute no papel do conhecimento na sociedade moderna: deixa de ser um otium (ciência pura) para converter-se num negócio, como pontua Hilton Japiassu $^{69}$. E ainda segundo o autor

a burguesia nascente, ao apropriar-se da racionalidade científica, não reivindica o direito, por natureza, ao governo da sociedade. Simplesmente torna e assume o controle de sua vida social graças ao poder que lhe confere o conhecimento científico fundado num sistema de racionalidade permitindo-lhe, mediante a utilização das máquinas e das técnicas, o domínio das coisas. $\mathrm{E}$ ao apoderar-se da racionalidade técnica e científica, a burguesia a torna cúmplice do poder $^{70}$. [grifo nosso]

A racionalidade científica, portanto, contribui e aprimora os contornos da estrutura de poder na sociedade. Por racionalidade entende-se o uso da razão como instrumento de controle e organização da ação humana. Em especial, no que tange as relações de trabalho subordinado, será o conhecimento científico o elemento fundamental para o desenvolvimento da administração científica taylorista. E a introdução de técnicas de exploração de mão-de-obra com base nos recursos tecnológicos foi justificada pela ideia de maximizar a extração da força laborativa, a partir de uma organização do trabalho eficiente.

As questões atinentes aos impactos da cultura de organização de trabalho sobre o trabalhador serão oportunamente analisadas, mas não é demais antecipar aqui que, não obstante a existência de novas formas de organização - ditas participativas, ou seja, com colaboração ativa do trabalhador nos mecanismos decisórios -, é certo que as contínuas mudanças técno-científicas imprimem sobre o indivíduo trabalhador um extenuamento não apenas físico, mas também psicológico. Porém, o que cabe discutir a partir de agora é como a razão se institui como uma verdade absoluta e, portanto, tenha até mesmo sido cultuada como crença.

\footnotetext{
${ }^{69}$ JAPIASSU, Hilton. Como nasce a ciência moderna - e as razões da filosofia. Rio de Janeiro: Imago, 2007. p. 273.

${ }^{70}$ Id. Ibid., p. 274.
} 


\section{4. $O$ culto à razão humana}

Como aponta Oswaldo Giacóia Júnior, em seu breve e percuciente estudo sobre Nietszche, o homem libertado das cadeias da ignorância e da superstição, e a consagração da razão como a única crença admissível culminaram na confiança das possibilidades vislumbradas pela utilização industrial da ciência e da técnica: "Afinal, somos devotos do deus 'Logos', confiantes em sua onipotência", ${ }^{71}$.

A onipotência da racionalidade é consagrada na obra de René Descartes (15961650). A razão aparece em Descartes como patrimônio da humanidade e para utilizá-la é necessário um método. O método é o caminho que a razão deve seguir e ele deve ser o mais certo, reto e curto; para atender esses requisitos, o método cartesiano baseia-se na mathesis universalis, ou seja, na matemática ${ }^{72}$. Entretanto, Descartes não afirmou que seu método fosse o melhor, mas incitava as pessoas a adotarem o método que conduzisse a razão de cada um da melhor maneira ${ }^{73}$.

O culto da razão tem sua origem desde 1790, na França, e notabilizou-se como um culto cívico difundido em grandes festas. Como proposta de descristianização, o culto da razão passaria a ser reconhecida como a "religião" substituta da República Francesa pósrevolução. Voltaire (1694-1778) dizia que a religião natural são os princípios morais comuns a todo gênero humano ${ }^{74}$.

A partir do culto da razão, praticado desordenadamente pelos revolucionários franceses, em 1793, Robespierre estabeleceu o chamado Culto do Ser Supremo e várias igrejas foram convertidas em templos para veneração da Razão, que passa a assumir os contornos de única "Deusa" a ser reconhecida de forma universal na modernidade.

Ao mesmo tempo, aceita-se o relativismo no que tange as inclinações religiosas e, confirmando a separação total entre a Igreja Católica e o Estado, admite-se juridicamente a prática de outras religiões, como as protestantes e a judaica. Essa separação entre religião e

${ }^{71}$ GIOCÓIA JÚNIOR, Oswaldo. Nietzsche. São Paulo: Publifolha, 2000. p. 16.

${ }^{72}$ SILVA, Leandro Santos da; OLIVEIRA, Manoel Messias de. Os sentidos em Descartes: fonte de erro ou de conhecimento. Revista da Católica, Uberlândia, v. 1, n. 1, 2009. Disponível em: $<$ www.catolicaonline.com.br/revistadacatolica $>$.

${ }^{73}$ DESCARTES, René. Discurso do método. Trad. Enrico Corvisieri. In: DESCARTES, René. Descartes: vida e obra. Consultoria de José Américo Motta Pessanha. São Paulo: Nova Cultural, 1999. p. 61. (Col. Os pensadores).

${ }^{74}$ AULARD, François-Alphonse. Le culte de la raison et le culte de l'être suprême: (1793-1794): essai historique. Paris: Fèlix Alcan Éditeur, 1892. p. 7. 
o poder estatal estabelece, por sua vez, o distanciamento do enfoque filosófico e religioso da temática centrada no interior do ser humano - entendida aqui como consciência moral , das questões atinentes à vida em sociedade, ou seja, às relações entre os indivíduos. Todos, na condição de indivíduos, são considerados como seres racionais, iguais e plenamente livres para determinar o curso das suas ações e, perante o Estado, responsabilizar-se pelos resultados delas.

François-Alphonse Aulard (1849-1928) registrou em sua obra "Le culte de la raison et le culte de l'être supreme" a importância das ideias revolucionárias em torno do paradoxo de se instituir um "culto laico". O paradoxo confirma-se na proposta aos Jacobinos feita por Delacroix, em 03 de junho de 1792, de destruir o culto católico e de substituir as imagens dos santos pelas de Rousseau e de Benjamin Franklin. Essa moção foi declarada inconstitucional e recusada, dado que a Assembléia Constituinte Francesa entendeu somente reduzir a religião à sua essência primeira e nacionalizá-la. ${ }^{75}$

A tentativa de organização de uma Igreja Nacional havia sido concebida pelos revolucionários na Constituição de 1791, a partir da retirada do monopólio da Igreja Católica e a sua submissão ao Estado monárquico constitucional. Nas disposições das garantias fundamentais da Constituição de 1791, expressamente estabelece-se que "a lei não reconhece nem os votos religiosos, nem qualquer outro compromisso que seja contrário aos direitos naturais ou à Constituição" ${ }^{76}$

A Constituição de 1793, a primeira da República Francesa, retoma a forma da Declaração dos Direitos do Homem e do Cidadão de 1789 para dispor sobre os direitos naturais inerentes ao homem. ${ }^{77}$ A Constituição de 1795 mantém a estrutura inicial da Declaração de 1789 e acrescenta outros capítulos e títulos. O artigo 352 dessa Constituição traz texto próximo ao previsto nas disposições da Constituição de 1791, acima

\footnotetext{
${ }^{75}$ AULARD, François-Alphonse. op. cit., p. 18.

${ }^{76}$ FRANCE. Conseil Constitutionnel. Constitution de 1791. Disponível em: <http://www.conseilconstitutionnel.fr/conseil-constitutionnel/francais/la-constitution/les-constitutions-de-la-france/constitutionde-1791.5082.html>. Acesso em: 20 jul. 2010.

${ }^{77}$ Id. Conseil Constitutionnel. Constitution du 24 juin 1793. <http://www.conseil-constitutionnel.fr/conseilconstitutionnel/francais/la-constitution/les-constitutions-de-la-france/constitution-du-24-juin1793.5084.html>. Acesso em: 20 jul. 2010.
} 
reproduzido, porém se limita a não reconhecer os compromissos religiosos contrários aos direitos naturais, não se referindo à hipótese de contrariedade à Constituição. ${ }^{78}$

Uma vez que seu conteúdo foi absorvido pelas Constituições escritas, a Declaração dos Direitos do Homem e do Cidadão é relegada a segundo plano do ponto de vista normativo. Os direitos ali expressos derivavam da inspiração jusnatural e o Code Civil suplanta o idealismo do período revolucionário. O Code de 1804 não admite o direito natural como fonte do direito positivo. Estabelece-se assim uma ordem jurídica racional e "liquidava-se finalmente a ilusão de uma nova sociedade de cidadãos honestos, em que as normas do direito seriam substituídas por prescrições morais que determinassem uma conduta cívica, e os tribunais e julgamentos, por reconciliações amistosas" 79 . A razão deixa de ser o atributo humano que conduz à natureza das coisas, para assumir o papel de instrumento organizador e delimitador das ações humanas. O homem é racional, não porque naturalmente se dirige ao bem, mas é racional na medida em que pode prescrever as condutas aceitáveis e garantir a segurança nas relações interpessoais. Inicia-se um processo de separação entre "intenção" e o "direito", que implicou e implica até hodiernamente uma resistência para tornar eficazes os atualmente reconhecidos direitos fundamentais.

Por "direitos fundamentais" entendem-se os direitos humanos que alcançaram o status constitucional. Paulo Bonavides, citando Carl Schmitt, esclarece que são direitos fundamentais "todos os direitos ou garantias nomeados e especificados no instrumento constitucional" e que "receberam da Constituição um grau mais elevado de garantia ou de segurança; ou são imutáveis (unabänderliche) ou pelo menos de mudança dificultada (erschwert), a saber, direitos unicamente alteráveis mediante lei de emenda à Constituição" ${ }^{\prime 80}$. A distinção, então, que se estabelece entre direitos humanos e direitos fundamentais está no fato de os direitos fundamentais serem direitos humanos positivados no âmbito do ordenamento interno, enquanto os direitos humanos se encontram no plano das declarações e convenções internacionais ${ }^{81}$.

\footnotetext{
${ }^{78}$ FRANCE. Conseil Constitutionnel. Constitution $d u \quad 5$ Fructidor An III. Disponível em: $<$ http://www.conseil-constitutionnel.fr/conseil-constitutionnel/francais/la-constitution/les-constitutions-dela-france/constitution-du-5-fructidor-an-iii.5086.html>. Acesso em: 22 jul. 2010.

${ }^{79}$ CAENEGEM, R. C. van. Uma introdução histórica ao direito privado. Trad. Carlos Eduardo Lima Machado. São Paulo: Martins Fontes, 2000. p. 12.

${ }^{80}$ BONAVIDES, Paulo. Curso de direito constitucional. 13. ed. São Paulo: Malheiros Ed., 2003. p. 561.

${ }^{81}$ PEREZ LUÑO, Antonio Enrique. Derechos humanos, estado de derecho y constitución. 2. ed. Madrid: Tecnos, 1986. p. 30-31.
} 
As declarações de direitos humanos trazem em seu bojo a ideia de propostas, projetos, ou melhor, inspiração para o legislador, sem propriamente vinculá-lo aos seus termos. Mesmo quando inseridos nas Constituições e passam a ser direitos fundamentais a serem garantidos pela sociedade, persiste a dificuldade em torná-los plenamente eficazes. Mas de onde surgiria a resistência em aceitar a plena exigibilidade dos direitos fundamentais, uma vez que eles estariam consagrados na própria constituição? A análise da construção da ideia de prevalência da razão insinua a resposta: os direitos fundamentais têm como característica marcante a presença de conceitos jurídicos que não podem ser plenamente modelados, ou seja, fogem à métrica científica decantada nos séculos XVIII e XIX. Instaura-se um desafio da sociedade atual.

Como característica do pensamento nietszchiano, Giocóia Júnior ressalta a "espécie de sensor que registra e antecipa questões e desafios de nosso século". Nietzsche, alerta sobre as consequências que a fé na razão poderia resultar, passou a dedicar sua vida à compreensão: a) da inconsistência dos valores absolutos e tradicionais em face do progresso de conhecimento; b) da mistificação do homem moderno; c) da tarefa corajosa de pensar novos valores quando os valores venerados pelos homens modernos (falsos ídolos) forem destruídos. ${ }^{82}$

A razão é o signo da modernidade. A crença na razão é resultado dos impactos que as conquistas técnico-científicas imprimiram no mundo ocidental, que impulsionaram o homem a inquestionáveis progressos materiais.

Ocorre que a evolução material da humanidade veio acompanhada da hybris, que passa também a fazer parte da constituição do homem moderno. O maior desafio a enfrentar, então, seria admitir e compreender os limites da "deusa razão", quando os efeitos da lassidão dos contornos da concepção do homem moderno começassem a eclodir.

É interessante notar que Blaise Pascal (1623-1662) afirmou no fragmento de n. 182, de seus Pensamentos: "Nada existe tão conforme à razão quanto desmentir a razão" 83 . Se a razão pode ser desmentida, no pensamento de Pascal perde sentido a máxima "conhece-te a ti mesmo", pois, como salienta Blaise Pascal, entendida a máxima no sentido socrático ela

\footnotetext{
${ }^{82}$ GIOCÓIA JÚNIOR, Oswaldo. op. cit., p. 16-17.

${ }^{83}$ PASCAL, Blaise. Pensamentos. Trad. Mário Laranjeira. São Paulo: Martins Fontes, 2001. p. 73.
} 
não é só ineficaz, "mas também enganadora e equivocada", pois a verdade ultrapassa os limites da não-onipotente razão humana ${ }^{84}$.

Ainda que a razão humana não seja onipotente - e isso se torna aparente na medida em que se presenciam catástrofes ambientais, muitas delas promovidas exclusivamente pela ação humana -, não se nega o valor inestimável a ela atribuído. Não se discute que a capacidade de raciocinar inerente à espécie humana é um atributo de poder a distingui-lo dos demais animais. É o ser humano capaz de canalizar sua força para atingir os mais variados fins, que não somente os de sobrevivência e procriação. Porém, ao decretar a “destruição do mito”, a razão (logos) exsurge como mito inconsciente.

Assim, o culto à razão não constitui somente figura de estilo utilizada para descrever uma sobrevalorização do potencial mental do homem. Em termos filosóficos, cabe refletir sobre as ponderações de Michael Loughlin:

Ao invés de criar códigos de moral que simplificam a vida em sociedade, eles [os filósofos] deveriam mostrar aos indivíduos em conflito quais habilidades eles têm, a fim de dar significado a um mundo complexo e brutal. Nós não precisamos de grupo de princípios para doutores, enfermeiras ou administradores: nós precisamos de pessoas reflexivas, capazes de analisar os problemas, cientes das suas limitações, e capazes de distinguir o que faz sentido do que não faz sentido. ${ }^{85}$ [grifo nosso]

Extrai-se da citação acima a necessidade premente de ultrapassar os limites da avaliação objetiva e métrica, diante de uma realidade plural e complexa. Portanto, seria cabível admitir a perscrutação de novos mecanismos de análise dos problemas e busca de soluções. Isso significa que a razão não é descartada, porque é a partir dela que se torna cognoscível o universo circundante e todas suas facetas. Mas é necessário reconhecer as limitações de um discurso racionalizante dissociado das reais relações sociais existentes.

O discurso, segundo Michel Foucault, não é simplesmente aquilo que traduz as lutas e os sistemas de dominação, mas aquilo por que e por meio do que se luta, aquele poder de que quer se apropriar ${ }^{86}$. É na prática (agir) que o discurso é vislumbrado. Em Foucault, enunciados, instituições, textos, falar e ver são práticas sociais intrinsicamente atreladas às relações de poder. Por isso, o discurso não é mera referência a "objetos" ou

\footnotetext{
${ }^{84}$ CASSIRER, Ernst. op. cit., p. 26.

${ }^{85}$ LOUGHLIN, Michael. Ethics, management and mythology: rational decision making for health service professionals. Abingdon: Radcliffe Medical Press, 2002. p. 186.

${ }^{86}$ FOUCAULT, Michel. El orden del discurso. Trad. Alberto González Troyano. Buenos Aires: Tusquets Editores, 1992. p. 12.
} 
mera utilização de letras, palavras e frases; ele é descrito e compreendido por si mesmo, pois as regras de formação dos conceitos compõem uma regularidade intrínseca ao próprio discurso, ou seja, as regras "estão no próprio discurso e se impõem a todos aqueles que falam ou tentam falar dentro de um determinado campo discursivo" ${ }^{87}$. Assim, a formação dos conceitos obedece a regras que "não residem na mentalidade nem na consciência dos indivíduos".

A concepção de discurso de Foucault enfatiza a necessidade de superação de um modelo rígido, objetivo e imutável de compreensão da realidade. Se o discurso se revela por si mesmo, a partir da prática das relações de poder e saber, os enunciados e os conceitos são elementos dinâmicos e não dados apriorísticos.

As limitações do discurso racionalizante decorrem, então, da tentativa de formatar um cenário conforme parâmetros pré-estabelecidos e impostos em caráter abstrato e universal. Uma coisa é racionalizar e tornar possível a compreensão de um fenômeno, outra é impor modelos e valores, em razão do exercício do poder de forma explícita ou simbólica. O ordenamento jurídico do Estado Social Democrático de Direito rechaça o exercício do poder pela força física (vis), assegurando o monopólio da força ao aparato estatal, no âmbito estrito do previsto em lei. Assoma a questão quanto ao emprego do poder simbólico. Pierre Bourdieu definiu o poder simbólico como "poder invisível, o qual só pode ser exercido com a cumplicidade daqueles que não sabem que lhe são sujeitos ou mesmo que o exercem" 88 .

O positivismo e a codificação do Direito são exemplos da prática de fixar parâmetros estanques e definidos para a verificação da realidade social, com afastamento das discussões sobre o alcance e os limites dos princípios derivados de uma ordem jurídica natural, inerente ao ser humano. Assim, ao direito natural se sucede um paradigma de

\footnotetext{
${ }^{87}$ FISCHER, Rosa Maria Bueno. Foucault e a análise do discurso em educação. Cadernos de pesquisa, São Paulo, v. 114, p. 200, nov. 2001. Disponível em: <www.scielo.br/pdf/cp/n114/a09n114.pdf>. Acesso em: 15 set. 2010.

${ }^{88}$ BOURDIEU, Pierre. O poder simbólico. Trad. Fernando Tomaz. 11. ed. Rio de Janeiro: Bertrand Brant, 2007. p. 7-8. "O poder simbólico, poder subordinado, é uma forma transformada, quer dizer, irreconhecível, transfigurada e legitimada, das outras formas de poder; só se pode passar para além da alternativa dos modelos energéticos que descrevem as relações sociais como relações de força e dos modelos cibernéticos que fazem delas relações de comunicação, na condição de descreverem as leis de transformação que regem a transmutação das diferentes espécies de capital em capital simbólico e, em especial, o trabalho de dissimulação e de transfiguração (numa palavra, de eufemização) que garante uma verdadeira transubstanciação das relações de força fazendo ignorar-reconhecer a violência que elas encerram objectivamente e transformando-as assim em poder simbólico, capaz de produzir efeitos reais sem dispêndio aparente de energia". (Id. Ibid., p. 14-15).
} 
construção de Direito baseada nos ditames técnico-científicos da era moderna: racional e objetiva.

\section{A racionalidade científica e sua influência no Direito}

A noção de Direito está intrinsecamente relacionada à ideia do agir humano. Dessa premissa inicial, decorre uma indagação: “o agir humano estaria condicionado ou é determinado por fatores alheios à vontade do homem?" Com base no item anterior e no enunciado proposto, o questionamento sobre a existência de uma escolha pelo agir ou não agir lança os olhos sobre os limites da liberdade humana.

\subsection{A disciplina do agir humano para os antigos}

Tércio Sampaio Ferraz Júnior, em suas reflexões sobre a concepção da liberdade, aponta que, na Antiguidade Clássica, “a liberdade não é um poder de escolha, mas uma necessidade interna de querer o próprio ser como sua mais alta possibilidade, donde querer algo impossível é ser não-livre: não se pode querer o que não se pode". ${ }^{89}$

Se os gregos antigos afirmavam a existência de direitos de caráter universal, essa universalidade ainda é definida pelo aspecto religioso e transcendental, de sorte que não havia espaço para questionar a vontade de agir do homem. Segundo John Gillisen, "o direito das cidades gregas não parece ter sido formulado nem sob a forma de textos legislativos, nem sob a de comentários de juristas; o direito derivaria mais duma noção mais ou menos vaga de justiça que estaria difusa na consciência colectiva" ${ }^{90}$.

Destaca Tércio Sampaio Ferraz Júnior que, na epopeia homérica, o ser humano respondia às suas inclinações naturais, insubmisso a quaisquer forças externas, como representação da luta do homem contra seu destino. Mas prossegue o referido autor, a "expressão de um ideal - o herói homérico -, permanece, porém, nos limites de um

\footnotetext{
${ }^{89}$ FERRAZ JÚNIOR, Tércio Sampaio. Estudos de filosofia do direito: reflexões sobre o poder, a liberdade, a justiça e o direito. São Paulo: Atlas, 2002. p. 80.

${ }^{90}$ GILLISEN, John. Introdução histórica ao direito. Trad. A. Hespanha e L. M. Macaísta Malheiros. 3. ed. Lisboa: Fundação Calouste Gulbekian, 2001. p. 75.
} 
conceito facticamente negativo (não ser coagido), não chegando a conhecer uma determinação ética". ${ }^{91}$ Destarte, o agir humano não está submetido a uma escala de valores estabelecida pelo homem, porque a hierarquia dos bens, como escolha, é resultado da própria natureza (necessidade) e da razão, aqui entendida como tendência natural para a realização do que é possível. ${ }^{92} \mathrm{E}$, em um contexto aristotélico, o sentido da liberdade repousa na tendência humana a perseguir o bem. Como consequência disso, não há de se questionar a voluntariedade ou não dos atos humanos, porque, tendentes à realização das virtudes, não há responsabilidade pelos resultados produzidos pelo agir humano, dada a indeterminação do alcance dos meios empregados para atingir os fins pretendidos. ${ }^{93}$ Se os resultados forem danosos, não é o homem responsável, pois a ele não se imputa a escolha daqueles resultados. A tendência humana é a busca do Bem, mas ninguém estaria livre da influência do acaso, que poderia, então, se manifestar na escolha equivocada dos meios para praticar a virtude ${ }^{94}$. Reforça-se a ideia do transcendente a determinar os contornos da ação humana. Porém, adverte Tércio Sampaio Ferraz Júnior que "na Antiguidade clássica, uma elaboração filosófica da liberdade como núcleo metafísico de uma concepção antropomórfica não chega a realizar-se". ${ }^{95}$

Não é demais mencionar que, no direito romano, as leis por muito tempo constituíram assunto sagrado e não se acreditava que a unanimidade de sufrágios fosse suficiente para promulgar uma lei, pois não viam nela obra humana ${ }^{96}$. Por conta dessa característica, o direito era civil, ou seja, peculiar a cada cidade, de sorte que "as leis só tinham valor e ação entre os membros de uma mesma cidade" ${ }^{97}$. A conclusão a ser extraída desse fato é a de que, em princípio, os romanos não conheciam um direito com natureza imutável e universal. Ademais, esse Direito, restrito a um grupo determinado e sagrado, não era conhecido por todos, tinha um caráter misterioso; tampouco trazia em si a

\footnotetext{
${ }^{91}$ FERRAZ JÚNIOR, Tércio Sampaio. op. cit., p. 78.

${ }^{92}$ Id. Ibid., p. 81.

${ }^{93}$ Id. Ibid., p. 82.

${ }^{94}$ Vale lembrar o estoicismo (300 a.C. a 200 a. C.), que sustenta a importância de não ceder aos impulsos passionais nem se curvar à força das emoções; para os estóicos, o homem deve viver de acordo com a razão, superando os instintos. Somente assim ele conseguirá atingir a virtude, ou seja, os estóicos destacaram o estudo da ética como campo de conhecimento. A classificação das virtudes, segundo a filosofia estóica, está baseada nos ensinamentos de Platão, e seriam quatro as virtudes: sabedoria, coragem, justiça e temperança.

${ }^{95}$ FERRAZ JÚNIOR, Tércio Sampaio. op. cit., p. 83.

${ }^{96}$ COULANGES, Foustel de. A cidade antiga: estudos sobre o culto, o direito, as instituições da Grécia e de Roma. Trad. José Camargo Leite e Eduardo Fonseca. São Paulo: Hemus, 1975. p. 152.

${ }^{97}$ Id. Ibid., p. 154.
} 
preocupação com a justiça de seus comandos. Enfim, o direito nascera da ideia de religião e não da noção de justiça ${ }^{98}$.

Após as revoluções da plebe e a Lei das Doze Tábuas, o direito romano deixa de ser algo misterioso, restrito a um grupo privilegiado, tornando-se conhecido por todos, e a lei passa ser fruto da vontade da maioria ${ }^{99}$. A partir da Lei das Doze Tábuas, o pretor traça um "direito absolutamente novo, não inspirado pela religião e aproximando-se cada dia mais do direito natural" 100 .

Na obra De Republica, do orador Cícero (106-43 a.C), encontra-se uma das mais emblemáticas definições de direito natural:

O verdadeiro direito é a razão de acordo com a Natureza; é de aplicação universal, imodificável e permanente; ele conduz ao dever pelos seus comandos e afasta da má conduta pelas suas proibições. E ele submete os homens bons a seus comandos e proibições, embora não tenha qualquer efeito sobre os maus. É um pecado tentar alterar esse direito, nem é permissível tentar repelir qualquer parte dele e é impossível aboli-lo inteiramente. Nós não podemos ser liberados das suas obrigações pela ação do Senado ou do Povo e nós não precisamos procurar um expositor ou um intérprete do direito. E não haverá diferentes leis em Roma e em Atenas, ou diferentes leis agora ou no futuro, mas um eterno e imutável direito será válido para todas as nações e em todos os tempos e haverá um mestre e um legislador, que é Deus, sobre todos nós, porque ele é o autor desse direito, seu promulgador e seu executor. ${ }^{101}$

Pelos romanos, foi adotada, então, a "noção grega de leis não escritas, com a expressão ius gentium, isto é, o direito comum a todos os povos" ${ }^{102}$. A partir da concessão da cidadania a todos os habitantes livres do império romano, consagrada em 212 d.C., com a Constituição de Caracala, diminuiu a importância da distinção entre jus gentium e jus

${ }^{98}$ COULANGES, Foustel de. op. cit., p. 154.

${ }^{99}$ Id. Ibid., p. 246-247. É importante destacar que as revoluções das classes desprestigiadas da sociedade romana representam uma mudança no perfil das instituições, o que não ocorre imediatamente. Foustel de Coulanges lembra: "Na verdade, esta evolução no direito não pode operar-se de um só golpe, de uma só vez. Se algumas vezes é possível ao homem modificar bruscamente as suas instituições políticas, não pode, contudo, alterar as leis e o direito privado senão muito devagar e gradativamente. Prova-se esta assertiva tanto com a história do direito romano, como a do direito ateniense". (Id. Ibid., p. 247).

${ }^{100}$ Id. Ibid., p. 248-249.

${ }^{101}$ MARCUS TULLIUS CICERO. De Republica, III, xxii, 33. In: D’ENTRÈVES, Alexander Passerin. Natural law: an introduction to legal philosophy. New Jersey: Transaction Publishers, 2004. p. 25.

${ }^{102}$ COMPARATO, Fábio Konder. A afirmação histórica dos direitos humanos. 2. ed. São Paulo: Saraiva, 2001. p. 14. Nas institutas de Gaio, cerca de 160 d. C., distingue-se o que é direito civil e natural: "Acerca do direito civil e natural. 1.1. (...) chama-se direito civil (direito dos cidadãos), como direito próprio da cidade; no entanto, aquele que é instituído entre todos os homens pela razão natural, esse é observado em geral entre todos os povos e chama-se direito das gentes, como direito de todas as nações. E assim o povo romano usa um direito que em parte lhe é próprio e em parte comum a todos os homens". (GILLISEN, John. op. cit., p. 95-96). 
civile. No século 3 a.C., a legislação imperial ganhou importância no sistema legal romano. No Corpus Iuris Civilis ${ }^{103}$, o "ius naturale" é reconhecido, mas não consta que seja superior ao direito positivo. No Digesto, encontra-se também a distinção entre direito natural e direito positivo: o direito natural é imutável, universal e estabelece o que é bom (critério moral), enquanto o direito positivo é particular e fixa o que é útil (critério econômico ou utilitário) ${ }^{104}$.

O cristianismo encontrou ressonância nos fundamentos do estoicismo e conservou o respeito ao Estado, por ser este reflexo da autoridade divina. Mas o homem já não depende do Estado para tudo ${ }^{105}$. Em Mateus, capítulo 22, versículo 21, Jesus adverte: "Daí, pois, a César o que é de César, e a Deus o que é Deus" ${ }^{106}$, estabelecendo claramente a distinção entre Estado e autoridade divina. É a referência bíblica ao que se convencionou chamar direito de resistência.

Com a doutrina cristã, despertam-se os ideais de igualdade e fraternidade universais. A ideia de que os indivíduos podem ser reduzidos a um conceito ou categoria geral é recente na História ${ }^{107}$. Não há expressão mais clara de igualdade e fraternidade que a declaração de que todos são filhos de um mesmo Pai, acrescida do considerado maior mandamento - amar o próximo -, encontrada nos ensinamentos cristãos.

\subsection{O direito natural}

Durante o século XVI, o direito natural foi praticamente definido pelos teólogos cristãos. A escolástica determinou qual a concepção de direito a ser adotada e dominou as escolas cristãs medievais e universidades europeias da metade do século XI até

\footnotetext{
${ }^{103 ، " C h a m a-s e, ~ p o i s, ~ C o r p u s ~ J u r i s ~ C i v i l i s ~ o ~ c o n j u n t o ~ d o ~ d i r e i t o ~ r o m a n o ~(o p o s t o ~ a o ~ C o r p u s ~ J u r i s ~ C a n o n i c i), ~}$ compilado no século VI da era cristã por ordem do imperador JUSTINIANO e, logo a seguir, pôsto em vigor em toda parte do império sob seu domínio". (CRETELLA JÚNIOR, José. Curso de direito romano. Rio de Janeiro: Forense, 1968. p. 49).

${ }^{104}$ BOBBIO, Norberto. O positivismo jurídico: lições de filosofia do direito. Trad. Márcio Pugliesi, Edson Bini e Carlos E. Rodrigues. São Paulo: Ícone, 1995. p. 30.

${ }^{105}$ José Soder reproduz a exegese de H. Schlier sobre a concepção cristã de Estado, cujas características seriam: "1. O Estado não significa instância última, da qual vive e depende o homem, pois não é e não possui a verdade. - 2. O Estado é uma ordem estabelecida por DEUS. Como tal possui poder incondicional sôbre o indivíduo, podendo exigir dêste obediência e respeito. - 3. Caso o Estado não reconheça esta sua finalidade, requerendo transformar-se em instituição de salvação dos homens, então se torna anticristão. Mas continua, mesmo assim, com o poder, dispondo sôbre a vida dos homens, embora injustamente." (SODER, José. Direitos do homem. São Paulo: Companhia Editora Nacional, 1960. p. 29).

${ }^{106}$ BÍBLIA (N.T.). Evangelho de São Mateus. Trad. Pe. Matos Soares. 11. ed. São Paulo: Edições Paulinas, 1982. p. 1207.

${ }^{107}$ COMPARATO, Fábio Konder. A afirmação histórica dos direitos humanos, cit., p. 11.
} 
aproximadamente metade do século XV. A proposta foi conjugar os conhecimentos gregos e a sabedoria cristã. A preocupação dos escolásticos não era descobrir novos fatos, mas entrelaçar o que já havia sido produzido pelos gregos (em termos de conhecimento) e a filosofia cristã, ou seja, estabelecer harmonia entre a razão e a revelação divina. Para os escolásticos, tal tarefa seria possível porque todo conhecimento e a verdade adviriam da mesma fonte, Deus. A contradição aparente identificável entre razão e a fé deriva do uso incorreto da razão na interpretação da verdade divina.

Depois do século XIII, o pensamento escolástico distanciou-se da filosofia, embora essa última tenha sido classificada como "serva" da teologia, na medida em que a teologia utilizava o termo "filosofia" para designar o estudo e a interpretação da verdade divina. Aristóteles foi considerado a maior autoridade em filosofia pelos escolásticos. Chamavamno simplesmente de "o filósofo". Sua irrestrita aceitação dos conhecimentos aristotélicos foi uma das principais razões responsáveis pela rejeição e desprezo dos cientistas a partir da Renascença.

Entre os escolásticos, destacam-se Santo Tomás de Aquino e Francisco Suaréz. Santo Tomás de Aquino (1225- 1274 d.C.), em sua Suma Teológica (1265-73), enuncia a lei da criação universal. A lei eterna confere a cada ser a inclinação para determinadas ações e objetivos que são apropriados a cada qual. As criaturas racionais, por sua vez, ao dirigirem suas próprias ações e guiá-las para alcançar seus propósitos e também de terceiros, carregam dentro de si a razão divina, ou seja, participam da criação. A esse atributo dos seres racionais dá-se o nome de direito natural. O direito natural corresponde às inclinações básicas da natureza humana, permitindo ao homem distinguir o bom do mau conforme a razão.

A Renascença pôs em xeque toda essa construção doutrinária de direito natural da Escolástica. A universalidade do direito natural apregoada pela escolástica enfrenta uma crise diante do relativismo das questões atinentes à ética e à moral. O direito natural dos escolásticos confere ao homem a capacidade de distinguir o que é bom do que é mau, o que é justo do que é injusto, o que conduz do que não conduz ao bem comum. Mas existe uma medida para estabelecer universalmente os valores inalienáveis, abrangidos pelo direito natural? Atribui-se a Aristóteles a origem do relativismo, que serviu de referência no campo das ciências morais. Para o autor de Ética a Nicômaco, não é possível atingir a 
mesma certeza que se alcança com as ciências matemáticas, quando o estudioso se propõe a conhecer conceitos éticos como justiça ou injustiça ${ }^{108}$.

Por conta do resgate do pensamento aristotélico, ao longo de séculos, o jurista foi educado através do ensinamento da tópica, isto é, "dos lugares de onde se podem extrair argumentos pró ou contra uma opinião, através da dialética ou arte de querelar e da retórica ou arte de convencer $" 109$.

Na Idade Moderna, encontrar o direito natural traduziu-se na busca do que há de mais autenticamente humano, no seu estado de pureza ${ }^{110}$. Hugo Grócio é considerado o fundador da moderna teoria de direito natural. Ele define direito natural como um corpo de normas que podem ser descobertas pelo uso da razão, mas independem da existência de Deus ou da obediência dos homens aos preceitos divinos. Dessa forma, Grócio rompe com a escolástica e define o caminho a ser traçado pelas teorias racionalistas desenvolvidas a partir dos séculos XVII e XVIII.

Como consequência desta evolução, Norberto Bobbio destaca que, não obstante o fato de a ideia de direito natural remontar à época clássica e subsistido na Idade Média, somente se pode falar em doutrina ou escola do direito natural durante a Idade Moderna, ou seja, no período compreendido entre os séculos XVII e XVIII ${ }^{111}$, intervalo esse que coincide com o surgimento dos Estados modernos até a Revolução Francesa. É nesse período que ocorre a secularização do direito natural escolástico, o novo direito natural

\footnotetext{
${ }^{108}$ Aristóteles enuncia, em Ética a Nicômaco, que todas as nossas ações se dirigem a um fim determinado. Este fim deve ser o "sumo bem" e a proposta de sua obra é determinar o que vem a ser este bem. Este também é o objeto da ciência política e, para Aristóteles, a investigação das ações belas e justas comporta variadas e flutuantes opiniões, "a ponto de não poder considerá-las como existindo apenas por convenção, e não por natureza". Prossegue o filósofo grego, afirmando que "igualmente em relação aos bens, existe uma flutuação semelhante, em razão de poderem ser, para muitas pessoas, até prejudiciais: por exemplo, houve quem perecesse por causa de sua riqueza, e outros por sua coragem" (ARISTÓTELES. Ética a Nicômaco. Trad. Pietro Nassetti. São Paulo: Martin Claret, 2002. p. 17-18). Daí resulta o relativismo que servirá de base para os renascentistas se oporem aos escolásticos. Entretanto, vale destacar que Aristóteles, ao longo de sua obra, reconhece a existência de uma justiça denominada por ele de "natural". Haveria, pois, duas partes componentes da justiça política: a natural e a legal: "A parte natural é aquela que tem a mesma força em todos os lugares e não existe por pensarem os homens deste ou daquele modo. A legal é o que de início pode ser determinado indiferentemente, mas deixa de sê-lo depois que foi estabelecido (por exemplo, que o resgate de um prisioneiro seja de uma mina, ou que deve ser sacrificado um bode e não duas ovelhas), e também todas as leis promulgadas para casos particulares (como a que mandava oferecer sacrifícios em honra de Brásidas), e as prescrições dos decretos". (Id. Ibid., p. 117) Esse entendimento não implica que a "justiça política natural" seja imutável; admite-se que seja universal, mas o "justo por natureza", para Aristóteles, é mutável.

${ }^{109}$ BOBBIO, Norberto; BOVERO, Michelangelo. Sociedade e Estado na filosofia política moderna. Trad. Carlos Nelson Coutinho. 3. ed. São Paulo: Brasiliense, 1991. p. 20-21.

${ }^{110}$ RECASENS SICHES, Luis. Vida humana, sociedade y derecho: fundamentácion de la filosofía del derecho. 2. ed. México: Fondo de Cultura Económica, 1945. p. 416.

${ }^{111}$ BOBBIO, Norberto; BOVERO, Michelangelo. op. cit., p. 13.
} 
aporta no mundo fenomênico dos homens, onde reina o relativismo ${ }^{112}$ e a nova ciência da moral nasce com o propósito de aplicar ao estudo da moral as técnicas da razão.

Uma das grandes questões suscitadas pelos iluministas era a seguinte: os direitos naturais são anteriores ao Estado ou decorrem da existência deste? Desenvolvem-se, nesse momento, as teorias do contrato social, fundamentais para a compreensão da posição dos direitos humanos na atualidade.

\subsection{O contratualismo social: a criação da ordem sócio-política e jurídica pela razão humana}

O contratualismo torna-se uma doutrina a partir do século XVI. Thomas Hobbes (1588-1679) defendeu o entendimento de que o homem somente se agrupa por interesse; o homem não é um ser político por natureza. Jean-Jacques Chevallier, em sua interpretação da obra "O Leviatã", escreve que, para Hobbes, "o homem só busca companheiros por interesse, por necessidade; a sociedade política é o fruto artificial de um pacto voluntário, de um cálculo interesseiro" ${ }^{113}$. Thomas Hobbes é um teórico do poder absoluto e critica qualquer forma de limitação ao poder estatal. Por força deste entendimento, Hobbes já foi considerado, por alguns autores, como o precursor do positivismo jurídico ${ }^{114}$.

Hobbes distingue entre direito natural e leis naturais. O direito natural é a liberdade de cada um para usar o seu poder, enquanto as leis da natureza são preceitos racionais que asseguram ao homem sua própria conservação e defesa. Tornar exigíveis estes preceitos é o grande desafio, que somente pode ser superado a partir da existência de um poder irresistível que obrigue o homem a obedecê-los, uma criatura superior: o Estado. Pela via deste contrato ("transferência mútua de direitos"), os homens transferem a um terceiro ente - o Estado - o direito natural (a liberdade) que possui no estado da natureza. É o Estado que controlará os impulsos humanos e garantirá a proteção dos seus membros. Em oposição ao estado da natureza, caracterizado pela guerra de todos contra todos, o Estado visa à instauração e manutenção da paz social. A promulgação de leis é decorrência da atribuição

\footnotetext{
${ }^{112}$ VASCONCELOS, Arnaldo. Direito, humanismo e democracia. São Paulo: Malheiros, 1998. p. 31.

${ }^{113}$ CHEVALLIER, Jean-Jacques. As grandes obras políticas de Maquiavel a nossos dias. Trad. Lydia Christina. 3. ed. Rio de Janeiro: Agir, 1986. p. 70.

${ }^{114}$ Cf. BOBBIO, Norberto. O positivismo jurídico: lições de filosofia do direito, cit., p. 34.
} 
do poder ao Estado: “Onde não há poder comum não há lei. Onde não há lei não há injustiça". 115

Ao considerar a celebração de um contrato pelos homens, Hobbes parte do pressuposto da igualdade de todos os contratantes: "Observa-se que a natureza fez os homens tão iguais, no que se refere às faculdades do corpo e do espírito que, embora por vezes se encontre um homem visivelmente mais forte de corpo, ou de espírito mais vivo do que outro, quando se considera tudo isso em conjunto, a diferença entre um e outro não é suficientemente considerável para que qualquer um possa com razão nela reclamar qualquer benefício a que outro não possa também aspirar, tal como ele"116. Hobbes, portanto, sustenta a igualdade entre os homens com fundamento nos aspectos naturais do homem individualmente observado, sem cotejar os fatores sócio-econômicos da vida em comunidade. Para o filósofo inglês, a natureza humana, de um ponto de vista psicobiológico, assegura certo grau de igualdade e desconsidera o fato de que as relações sociais promovem distinções entre os homens.

A transferência do direito natural a um ente superior faz-se com que se garanta uma situação melhor, pois "o objetivo de todos os atos voluntários dos homens é algum bem para si mesmos" ${ }^{117}$. Para Hobbes, é a própria razão que incita a adoção de normas de paz, a partir das quais os homens conseguem firmar o acordo. São essas normas as leis naturais. As leis naturais, todavia, têm sua origem no foro íntimo e podem ser facilmente violadas. A conclusão a que se chega é a de que as leis naturais não são normas jurídicas, porque não são elaboradas por um poder constituído para tanto, estabelecido no contrato social ${ }^{118}$, tampouco são dotadas da coercitividade que garante o respeito aos preceitos e a consequente segurança das relações sociais.

Segundo aponta Norberto Bobbio, "com base nesta concepção Hobbes nega a legitimidade da common law, isto é, de um direito preexistente ao Estado e independente deste (seria quase uma espécie de direito natural) (...) para Hobbes o direito é expressão de quem tem o poder e por isto ele nega o valor à common law"119.

\footnotetext{
${ }^{115}$ HOBBES, Thomas. Leviatã, ou matéria, forma e poder de um Estado eclesiástico e civil. Trad. Alex Marins. São Paulo: Martin Claret, 2002. p. 99.

${ }^{116}$ Id. Ibid., p. 96.

${ }^{117}$ Id. Ibid., p. 103.

118"Nenhuma lei pode ser feita antes de se determinar qual pessoa irá fazê-la". (Id. Ibid., p. 99).

${ }^{119}$ BOBBIO, Norberto. O positivismo jurídico: lições de filosofia do direito, cit., p. 35-36.
} 
Quanto à justiça das leis, para Hobbes, nenhuma lei pode ser injusta e somente é lei aquela emanada do Poder, ou seja, do Estado. Mais uma vez, evidencia-se a clara expressão do positivismo jurídico, em que o formalismo e o caráter imperativo são os elementos identificadores da norma jurídica. Enfim, direito natural, como reflexos da Razão Universal não são, para Hobbes, Direito.

Thomas Hobbes justifica um Estado Absolutista, detentor de um poder ilimitado de fazer e desfazer as leis. Quais leis? "Boas" leis, que seriam aquelas "necessárias" ao bem do povo e que garantam a segurança. Na medida em que o soberano não atender a esse compromisso, os súditos encontram-se desobrigados com o Estado, retomando o direito natural absoluto e a possibilidade de firmar outro pacto.

Outro grande contratualista é John Locke (1632-1704). Fritjof Capra destaca a influência de Newton e Descartes na obra de Locke, o qual desenvolveu uma concepção atomística da sociedade. ${ }^{120}$ Locke opõe-se ao governo absolutista. As bases da teoria de Locke são as mesmas de Hobbes: o estado de natureza e o contrato social, mas sua proposta é anti-absolutista. Segundo Locke, o estado de natureza não consistiu em uma guerra de todos contra todos, como vislumbrava Hobbes, mas é um estado de total liberdade e igualdade. A exemplo dos pressupostos de estabilidade dos fenômenos físicos, conforme as leis da natureza, os fenômenos sociais também são regidos por leis da natureza, semelhantes às que governam o universo físico:

Tal como os átomos de um gás estabelecem um estado de equilíbrio, também os indivíduos humanos se estabilizariam numa sociedade num 'estado de natureza'. Assim, a função do governo não seria impor suas leis às pessoas, mas, antes, descobrir e fazer valer as leis naturais que existiam antes de qualquer governo. Segundo Locke, essas leis naturais incluíam a liberdade e a igualdade entre todos os indivíduos, assim como o direito à propriedade, que representava os frutos do trabalho de cada um. ${ }^{121}$

A opção pelo estado de sociedade repousa no interesse do homem em aprimorar sua condição, pois: "no estado natural, cada um é juiz em causa própria; cada um, igual ao outro, é de certo modo rei; pode achar-se tentado a observar com pouca exatidão a equidade". ${ }^{122}$ Falta, nesse estado de natureza, "um poder coativo, capaz de assegurar a

\footnotetext{
${ }^{120}$ CAPRA, Fritjof. $O$ ponto de mutação: a ciência, a sociedade e a cultura emergente, cit., p. 64 .

${ }^{121}$ Id., loc. cit.

${ }^{122}$ CHEV ALLIER, Jean-Jacques. op. cit., p. 107.
} 
execução dos juízos proferidos". ${ }^{123}$ O Estado, portanto, constituído a partir do consentimento de seus membros, é formado para suprir a falta desse poder de coação. Esse poder, ao contrário de "O Leviatã", não é ilimitado, e encontra diante de si os direitos naturais dos homens, que subsistem e impõem limites ao poder do Estado ${ }^{124}$.

Em Locke, a opção por um estado de sociedade é para "conservar melhor as suas pessoas, liberdade e propriedade" ${ }^{125}$, ou seja, a finalidade do pacto social é defender primordialmente a vida, a liberdade e a propriedade. O direito, para Locke, é condição para a liberdade: "onde não há lei não há liberdade"126. A maior lei é a da razão e o homem é suficientemente racional para definir as demais leis.

Se a confiança do povo nos poderes estatais para a realização do bem público não for correspondida, têm os indivíduos, formadores que são da sociedade, direito de empregar a sua força contra o Estado. Foi o argumento por meio do qual Locke conseguiu aliviar a consciência dos ingleses, após a expulsão de Tiago II $^{127}$.

A doutrina de Locke pauta-se na premissa de que a natureza dotou os seres humanos de certos direitos inalienáveis, que não poderiam ser violados por nenhum governo. Esse pensamento foi incorporado na Declaração de Independência Norteamericana. Locke confere à teoria política contornos do liberalismo, que será o paradigma do período histórico.

Para Locke, não existe uma ética única, uma verdade absoluta sobre o que é certo ou errado, justo ou injusto; só há de se buscar o bem-estar comum e esse é o objetivo do Estado. Cabe a cada um definir seus padrões de consciência.

Para completar o estudo da teoria contratualista, menciona-se a obra clássica " $\mathrm{O}$ Contrato Social”, de Jean-Jacques Rousseau (1712-1778). A exemplo de Thomas Hobbes e John Locke, Rousseau fundamenta sua teoria sobre as bases do estado de natureza e do contrato social. Porém, o pensamento de Rousseau apresenta diferenças em face da teoria dos outros dois contratualistas. Para Rousseau, não é a razão, mas o sentimento que norteia

\footnotetext{
${ }^{123}$ CHEV ALLIER, Jean-Jacques. op. cit., p. 107-108.

${ }^{124}$ Id. Ibid., p. 112.

${ }^{125}$ Id., loc. cit.

${ }^{126}$ LOCKE, John. Dois tratados sobre o governo. Livro II. In: MORRIS, Clarence (Org). Os grandes filósofos do direito. Trad. Reinaldo Guarany. São Paulo: Ed. Martins Fontes, 2002. p. 141.

${ }^{127}$ CHEV ALLIER, Jean-Jacques. op. cit., p. 114.
} 
o conhecimento e, contrário ao ceticismo hobbesiano, acredita na bondade natural do homem e opõe-se ao absolutismo ${ }^{128}$.

Uma das inovações que o pensamento de Rousseau trouxe foi a constatação de que a liberdade não é somente um fato a ser observado empiricamente, mas um imperativo, uma norma que traduz a essência do homem, um direito da humanidade.

Rousseau reforça a ideia do pacto social, sob o argumento de que, no estado da natureza, os homens podem chegar a uma situação em que a sua conservação fica comprometida. Então, resta aos homens unir suas forças, "impelindo-as para um só móvel, levando-as a operar em concerto". ${ }^{129}$ Substitui-se a liberdade natural, irrestrita, pela liberdade convencional, socializada.

Segundo o pensamento de Rousseau, a partir do pacto social surge o governo civil, o corpo político, e as leis dão "movimento e vontade" à união dos homens. A discussão passa a ser: o que são as leis? Em Rousseau, a lei decorre da vontade geral, cujo objeto é ela própria. O interesse particular não está dentro ou fora do todo, pois "quando todo o povo estatui algo para todo o povo, só considera a si mesmo e, caso se estabeleça então uma relação, será entre todo o objeto sob um certo ponto de vista e todo o objeto sob um outro ponto de vista, sem nenhuma divisão do todo". ${ }^{130}$ A lei é abstrata e geral, e constitui condição para a associação civil. Não se pergunta se a lei é justa ou injusta, boa ou má, porque "a vontade geral é sempre certa" ${ }^{131}$. Cabe ao legislador, como representante da vontade geral, estabelecer as melhores regras para a sociedade política.

Thomas Hobbes serve de referência para a fixação das bases do positivismo jurídico, afastando a ética das questões político-jurídicas. Locke propõe as linhas diretoras do liberalismo, ao afirmar a razão humana individual como condutora do bem comum. Rousseau pauta-se na democracia, traduzida no ideal da vontade geral.

\footnotetext{
${ }^{128}$ Em oposição ao absolutismo, Rousseau sustenta que a segurança da tranquilidade civil não é suficiente para diante de guerras travadas pelo déspota em razão de "sua insaciável avidez". (ROUSSEAU, Jean-Jacques. O contrato social. Trad. São Paulo: Nova Cultural, 1999. v. 1, p. 61. (Col. Os pensadores).

${ }^{129}$ Id. Ibid., p. 69.

${ }^{130}$ Id. Ibid., p. 106.

${ }^{131}$ Id. Ibid., p. 109.
} 


\subsection{A construção do paradigma da modernidade}

Os contratualistas inauguram um período em que se valoriza a vontade humana como capaz de produzir as normas que definirão o modo de vida, e acabam por estabelecer paradigmas que ainda subsistem na atualidade e constituem base para a compreensão de Estado e da ordem jurídica.

O surgimento do contratualismo coincide com o momento em que o desenvolvimento do comércio tornou inviável a manutenção dos costumes e tradições feudais. Mas, muito além disso, a própria ampliação das relações comerciais é fruto das revoluções científicas, que comprovaram o poder da razão humana sobre a natureza. $\mathrm{O}$ Estado Moderno também se apresenta como resultado de uma criação da razão humana. $\mathrm{O}$ Estado da era Moderna é, pois, um ente abstrato. ${ }^{132}$

Na obra de Thomas Hobbes, cria-se a figura do Leviatã. Tércio Sampaio Ferraz Júnior explica que Hobbes descreve o Leviatã como um homem artificial, "que faz todas as leis, mas não se submete a nenhuma delas". Esse é o modelo de relação entre príncipe e principado e o Estado passa a ser responsável pela segurança, pela sobrevivência. ${ }^{133}$ Observa-se que a ideia de "homem artificial" evidencia a tecnologia pressuposta na construção do Estado hobbesiano. A partir de Foucault, Tércio Sampaio Ferraz Júnior destaca que, dentro dessa concepção de Estado, “a arte de governar está menos ligada a uma sabedoria prática, isto é, ao conhecimento da equidade, do bom julgamento, da justiça, e muito mais a um cálculo. [...] Essa transformação de visão jurídica para uma visão econômica do poder é ressaltada por Foucault" ${ }^{134}$.

Com relação à liberdade, Hobbes, como visto, concebia o Estado como construção da razão humana, isto é, como manifestação livre dos indivíduos em se submeter a um poder soberano. Mas a constituição do Estado, em nome da segurança de todos, implica a abdicação da liberdade de não ser impedido de agir (liberdade de não impedimento). Essa lógica reproduz uma das teses do paradigma da modernidade: o indivíduo racional e autointeressado visa à promoção de condições de cooperação e de garantia da vida. Daqui se extrai:

\footnotetext{
${ }^{132}$ FERRAZ JÚNIOR, Tércio Sampaio. Direito constitucional: liberdade de fumar, privacidade, Estado, direitos humanos e outros temas. Barueri/SP: Manole, 2007. p. 420.

${ }^{133}$ Id. Ibid., p. 421-422.

${ }^{134}$ Id. Ibid., p. 422-423.
} 
a)a valorização do indivíduo;

b)ser dotado de razão;

c)auto-interessado.

E, com base em um universo de indivíduos com as características acima, a criação do Estado é resultado de um mecanismo racional - o contrato moderno -, cujo objeto transacionado são direitos naturais:

A solução hobbesiana, por esta razão, implica em um tradeoff entre direito à vida e direito à liberdade natural. Os indivíduos, ao instituírem o Estado Civil por meio do contrato social, devem abrir mão de sua liberdade natural em favor de garantias efetivas ao seu direito à vida. ${ }^{135}$

Para poder abdicar de um bem (ainda que seja a liberdade de não ser impedido de realizar algo), é imperioso que seja pressuposta uma liberdade anterior: a liberdade natural. Aliás, é exatamente o perigo do exercício ilimitado da liberdade, no estado de natureza, que não oferece segurança aos indivíduos racionais. Se todos são auto-interessados e visam à maximização do seu bem-estar, o resultado é uma sociedade de risco permanente ao bem indispensável ao ser humano: a vida.

Thomas Hobbes, adverte Norberto Bobbio, "não defende a tese da renúncia total", mas o homem "renuncia a tudo o que torna indesejável o estado de natureza; mais precisamente, renuncia à igualdade de fato que torna precária a existência até mesmo dos mais fortes". ${ }^{136}$ Como a razão humana age de maneira auto-interessada, "a finalidade em função do qual o homem considera útil renunciar a todos esses bens é a salvaguardada do bem mais precioso, a vida" ${ }^{137}$. Dessa forma, o Estado vem a reconhecer direitos aos cidadãos, dentro dos limites calculados e necessários à manutenção da ordem e segurança.

Sobre o contratualismo em Locke, Tércio Sampaio Ferraz Júnior aponta que "o contrato social garante a liberdade para a sociedade natural", descrita "num sentido muito próximo de uma sociedade burguesa já desenvolvida". ${ }^{138}$

\footnotetext{
${ }^{135}$ CHIAPPIN, J. R. N.; LEISTER, C. O programa de pesquisa sobre a política e o direito como ciência e o problema das condições de emergência e estabilidade da cooperação entre indivíduos interagentes: a construção do Estado de Direito e a heurística do contratualismo. Parte II. 2007. No prelo. p. 8.

${ }^{136}$ BOBBIO, Norberto; BOVERO, Michelangelo. op. cit., p. 72.

${ }^{137}$ Id., loc. cit.

${ }^{138}$ FERRAZ JÚNIOR, Tércio Sampaio. Estudos de filosofia do direito: reflexões sobre o poder, a liberdade, a justiça e o direito, cit., p. 98-99.
} 
John Locke insere dois elementos fundamentais no aprimoramento do paradigma da modernidade, pois

\begin{abstract}
adota uma combinação e uma reinterpretação dos componentes do método contratualista para resolver o mesmo problema da cooperação restrito por sua axiologia, que agora contempla não apenas o direito à vida, mas, também o direito à liberdade e o direito à propriedade privada. Essa relação entre Locke e Hobbes no modo como abordam o problema dos direitos mostra um claro progresso relativamente à solução do problema hobbesiano no sentido de tornar o problema mais complexo, uma vez que requer a preservação de outros direitos que não apenas o direito à vida. ${ }^{139}$ [grifo nosso]
\end{abstract}

Formata-se, assim, a configuração do homem moderno, a partir dos elementos constitutivos abaixo:

a) da valorização do indivíduo;

b) da racionalidade (apologia à razão);

c) da motivação pelo auto-interesse;

d) da liberdade;

e) da propriedade.

Esse substrato teórico confere os contornos da estrutura jurídica da Modernidade e, já no século XIX, a própria existência de um direito natural é alvo de crítica. A configuração de um direito natural foi considerada improvável. A ética do utilitarismo, já encontrada em Beccaria (1738-1794), fundamentada na máxima "a maior felicidade para o maior número de pessoas", e a ética do positivismo jurídico alcançam seu apogeu. Um dos maiores representantes do utilitarismo é Jeremy Bentham (1748-1832). Bentham opõe-se ao sistema da common law, sob a alegação de que a produção judiciária do direito se traduz em incerteza para o cidadão. Influenciado pelo domínio da razão humana sobre a natureza e as relações humanas, Jeremy Bentham defende a possibilidade de se estabelecer uma ética objetiva, não com base na natureza do homem, mas com fundamento na utilidade a que o homem visa quando elabora as normas. O utilitarismo, portanto, defende a criação de um código fundado na razão humana, para alcançar o maior proveito de suas regras. A codificação das normas é então concebida como mecanismo de promoção de segurança e certeza jurídicas.

\footnotetext{
${ }^{139}$ CHIAPPIN, J. R. N.; LEISTER, C. op. cit., p. 8.
} 


\subsection{O positivismo jurídico e o processo de codificação como expressão da racionalidade científica no Direito}

A proposta de um direito racional - sistematizado, formalizado, monopolizado e burocratizado pelo Estado - afirma a possibilidade de normatizar todo comportamento humano, ou seja, assevera que todo o comportamento humano pode ser antecipável por meio de normas ${ }^{140}$.

A ideia de codificação encontra-se ligada ao Direito Romano. A primeira codificação foi o Codex Theodosianus, publicado por Teodósio II, em 438 d. C.. Em 533 d.C., Justiniano I indicou uma comissão de dez juristas para compilar as fontes antigas do direito romano. Foram publicados por Justiniano os seguintes livros: as Institutiones (533), o Digesto (Digesta ou Pandecta) (533), o Codex Constitutionum (528-29; revisado em 534), e as Novellae (534-65), conhecidos como Corpus Juris Civilis. A codificação atendeu a uma das funções do Direito romano: "eficiência das normas, notadamente no que diz respeito à integração dos povos por conta da expansão territorial do império romano" $^{141}$.

A concepção, porém, de que o Direito está encerrado em um código é uma experiência jurídica dos últimos dois séculos e típica da Europa continental $^{142}$. A sistematização das normas corresponde à valorização da racionalidade, discurso extraído do pensamento iluminista. O código deveria, como expressão da ética objetiva, ser completo e abranger todas as situações a que ele se destina regular. Destarte, costumes, usos, leis estrangeiras ou o direito natural não poderiam servir como fonte do direito, na medida em que somente o que estivesse no corpo do código constituiria lei ${ }^{143}$.

Essas construções doutrinárias paulatinamente esvaziam a influência do direito natural na concepção de Direito e inauguram o positivismo jurídico. Segundo Bobbio, o

\footnotetext{
${ }^{140}$ MÜLLER, Friederich. O novo paradigma do direito: introdução à teoria e metódica estruturantes. 2 . ed. São Paulo: Ed. Revista dos Tribunais, 2009. p. 123.

${ }^{141}$ SZTAJN, Rachel. Law and economics. In: ZYLBERSZTAJN, Decio; SZTAJN, Rachel. (Orgs.) Direito \& economia: análise econômica do direito e das organizações. Rio de Janeiro: Elsevier, 2005. p. 78.

${ }^{142}$ BOBBIO, Norberto. O positivismo jurídico: lições de filosofia do direito, cit., p. 63.

${ }^{143}$ Jeremy Bentham, contudo, entende que a atividade judiciária deve aplicar as regras preexistentes tendo em vista os interesses em conflito, ao contrário de uma visão estritamente positivista da atividade judiciária, segundo a qual o juiz deve aplicar a lei, sem contemplar dados (como os interesses das partes) que extrapolem a mera subsunção da norma ao caso concreto (BOBBIO, Norberto. O positivismo jurídico: lições de filosofia do direito, cit., p. 98).
} 
positivismo jurídico "é uma concepção do direito que nasce quando 'direito positivo' e 'direito natural' não mais são considerados como direito em sentido próprio". O resultado desta evolução histórica é a insustentabilidade da coexistência de direito natural e direito positivo, pois passa a se admitir como único direito o positivo. Não seriam mais duas espécies de um mesmo direito, mas se distingue claramente o que é direito positivo do que é direito natural, sendo que esse último não compõe o ordenamento jurídico. Prossegue o referido autor: "Por obra do positivismo jurídico ocorre a redução de todo o direito a direito positivo, e o direito natural é excluído da categoria do direito: o direito positivo é direito, o direito natural não é direito" ${ }^{144}$.

A principal diferença entre direito natural e direito positivo não estaria, porém, nas fontes, mas no modo pelo qual um ou outro é conhecido. Em ambos, a razão humana é pressuposta, contudo, se o direito natural é conhecido pela razão - pois dela deriva a natureza das coisas, aprioristicamente (concepção racionalista da ética) -, se conhece o direito positivo a partir da declaração de vontade do legislador. Ou seja, no direito positivo, a razão é instrumento para o processo de conhecimento do direito, enquanto no direito natural a razão determina o direito. Como consequência disso, o direito natural demonstra o que existe a priori e a razão identifica os comportamentos como bons ou ruins por si mesmos, com base no conhecimento apriorístico. Por outro lado, no direito positivo, não há bom ou ruim em si mesmo, mas os comportamentos assumem certa qualificação após serem disciplinados pelo direito positivo: é justo o que é ordenado e é injusto o que é $\operatorname{vetado}^{145}$.

Como pontos fundamentais da doutrina positivista, Norberto Bobbio aponta: a) modo de abordar o direito: direito como um fato e não como um valor; b) definição do direito: o direito é definido em função do elemento coação; c) fontes do direito: a legislação é a fonte preeminente do direito; d) a norma é um comando, um imperativo; e) o ordenamento jurídico é completo e coerente; f) para interpretar, o jurista faz prevalecer o elemento declarativo sobre o produtivo ou criativo do direito, o que conduz à ideia mecanicista no ato de interpretar a norma ${ }^{146}$; g) a existência de uma suposta ideologia

\footnotetext{
${ }^{144}$ BOBBIO, Norberto. O positivismo jurídico: lições de filosofia do direito, cit., p. 26.

${ }^{145}$ Id. Ibid., p. 22-23.

${ }^{146}$ Id. Ibid., p. 131-133.
} 
positivista que consiste no "dever absoluto ou incondicional de obedecer à lei enquanto tal"147.

Quanto ao último ponto fundamental, um dos mais notáveis esforços de sistematização de regras jurídicas de toda a história foi o esforço de Napoleão em dar à França um conjunto de códigos ${ }^{148}$. A partir da positivação na forma de códigos, estudamse as normas elaboradas pelo legislador: "não se ensina mais direito civil, há sim um curso de Código de Napoleão"

A conclusão a que se chega é que

O jusnaturalismo correspondia, sobretudo no fim do século XVIII, à teoria de que necessitava a burguesia ascendente para criticar a feudalidade e transformar a sociedade que se opunha ainda à sua dominação. O positivismo será, a partir da codificação napoleônica (de que é uma manifestação e não uma causa), a teorida de que tem necessidade uma burguesia que se tornou dominante no sistema sociopolítico $^{150}$.

O positivismo jurídico, portanto, exclui do Direito a abordagem sobre juízos de valor; o estudo do Direito, como ciência, atém-se às prescrições (normas). Tudo, então, pode ser controlado e explicado pela razão. Definitivamente o mundo deixou de ser algo misterioso.

Mas como se manifesta a liberdade do ser humano, como representação de anseios da consciência, desejos ou necessidades? Se as condutas humanas são prescritas e expectáveis conforme uma ordem racionalmente definida (positivada), como se processam as ações humanas, como resultado do exercício da liberdade, especificamente nas relações de trabalho subordinado?

\footnotetext{
${ }^{147}$ BOBBIO, Norberto. O positivismo jurídico: lições de filosofia do direito, cit., p. 225.

${ }^{148}$ GILLISEN, John. op. cit., p. 448.

${ }^{149}$ MIAILLE, Michel. Introdução crítica ao direito. Trad. Ana Prata. 3. ed. Lisboa: Editorial Estampa, 2005. p. 44.

${ }^{150}$ Id., loc. cit.
} 


\section{A complexidade das relações de trabalho subordinado e os direitos humanos sociais}

Sob o ideário iluminista e liberal, defendeu-se a igualdade formal, como lei a ser observada por todos. Semelhante discurso representou um certo avanço ${ }^{151}$ do ponto de vista político, porém, na esfera econômica, as relações de produção industrial acentuaram a alienação e reificação do trabalho humano, fenômeno esse iniciado na transição da produção artesanal para o modelo manufatureiro. Nesse contexto econômico, a base jurídica adotada de natureza civilista não "domesticou” o poder hegemônico do capital.

\subsection{A presença do poder das relações de trabalho subordinado}

A legitimidade da disciplina da relação de trabalho subordinado fundamentou-se na noção liberdade, a qual perpassou as engrenagens da construção sócio-política desenhada no modelo contratualista: "a liberdade e sua garantia passam a depender intrinsecamente daquilo que se constrói: a vontade geral". ${ }^{152}$ A liberdade manifesta-se na produção sistematizada de normas, derivadas de um poder constituído, consensualmente (vontade), pelos indivíduos. Sendo assim, a liberdade acaba por ser limitada pelo fruto do seu exercício, ainda que presumido: o direito positivo, expressão da "razão técnica" e, como tal, pressupõe-se neutro e desprovido de conotação valorativa.

No âmbito das relações jurídicas, explica Custódio da Piedade Ubaldino Miranda que:

O direito estatal, nesta nova concepção, deveria limitar-se a servir a vontade individual, complementando-a ou suprindo-a, com o fundamento na vontade presumida: 'voluntas facit legem'. Estes princípios ficariam inicialmente consagrados nos textos constitucionais, concernentes aos contratos e à propriedade e, em seguida, passariam para os Códigos, do mesmo passo que seriam aproveitados pelo pandectismo para as suas grandiosas construções científicas. ${ }^{153}$

\footnotetext{
${ }^{151}$ Reforça-se que os primados de igualdade e de liberdade representaram certo avanço, na medida em que não conferiu direitos a grupos restritos, ou seja, o ideal liberal-burguês não contemplou o universalismo de sujeitos dos direitos civis e políticos propalados à época.

${ }^{152}$ FERRAZ JÚNIOR, Tércio Sampaio. Estudos de filosofia do direito: reflexões sobre o poder, a liberdade, a justiça e o direito, cit., p. 99-100.

${ }^{153}$ MIRANDA, Custódio da Piedade Ubaldino. Teoria geral do negócio jurídico. São Paulo: Atlas, 1991. p. 39.
} 
A nova noção de liberdade configura o contrato moderno, o qual se converte em $\underline{\text { instrumento de promoção de relações civis e comerciais, regulado por leis gerais, abstratas }}$ e impessoais. Constata-se que toda essa construção está impregnada pelos postulados resultantes dos avanços científicos da modernidade: "o homem, livre no sentido positivo de autonomia, engaja-se na medida dos seus interesses e nessa medida responde pelo seu engajamento". 154

O contrato é instrumento para realização de interesses individuais e o indivíduo, sujeito de direitos, no absoluto uso da razão, avalia os ganhos e os custos de suas ações. E o Direito garante a estabilidade social, a partir da segurança das instituiçõos que possibilitam o pleno exercício de direitos humanos (liberdade como não impedimento).

Nesse primeiro momento da construção do Direito Moderno, a autonomia individual realiza-se na declaração (dado objetivo), em detrimento da intenção. A concepção de autonomia, por conseguinte, parte de uma abstração. Pressupõe-se que todos são capazes de dirigir sua vontade para a realização de objetivos auto-interessados, como seres racionais e detentores de todas as informações necessárias para auto-regular seus próprios interesses.

Por isso, no contexto do paradigma proposto pela Modernidade, surge a questão de como articular a necessidade de evitar distúrbios graves na estrutura da identidade pessoal de agentes sociais subjetivamente livres com a necessidade de constituir e estabilizar as expectativas desses agentes livres, mediante a constitucionalização de sistemas normativos objetivos. Com isso, a liberdade torna-se um problema e a consciência livre, algo que deve ser, ao mesmo tempo, garantido individualmente e delimitado socialmente. ${ }^{155}$

Prova disso foi a regulação da relação de trabalho subordinado - inicialmente, com natureza jurídica de contrato nos moldes civilistas -, a qual visou assegurar o domínio da classe burguesa/industrial sobre a classe trabalhadora, desconsiderando a sujeição de um (trabalhador) a outro (empregador).

Parte-se do pressuposto de que o sistema jurídico reproduz os legítimos interesses em nível de sociedade como um todo. Sendo assim, o Direito também acomoda o substrato

\footnotetext{
${ }^{154}$ FERRAZ JÚNIOR, Tércio Sampaio. Estudos de filosofia do direito: reflexões sobre o poder, a liberdade, a justiça e o direito, cit., p. 104.

${ }^{155}$ Id. Ibid., p. 98.
} 
econômico em sua base de referência, porém com esse não se confunde. Mas à medida que o sistema jurídico deixa de processar as mensagens de acordo com seus critérios, e a partir de referenciais ditados pelo sistema econômico, opera-se um processo de desestruturação dos elementos (conceitos, institutos, princípios) que compõem o sistema.

Autoridade, por exemplo, justifica a obediência a ordens emanadas por quem detém o poder. No nascedouro do modo capitalista de produção, a autoridade fez-se presente como mecanismo de exercício do poder, impingindo deveres ao trabalhador, sem qualquer referência à legitimidade ou meio de persuasão e diálogo igualitário. Isso decorreu da igualdade formal, a qual se baseava no homem como ser abstrato, descontextualizado do plano real. Os fatos comprovaram e comprovam a desigualdade material entre os homens. Prova disso foi o desconforto provocado pela obediência à força que resultou (e resulta) em insatisfação manifesta. É possível concluir que a base de referência econômica careceu de legitimação fora do seu sistema.

Max Weber, em sua análise sobre o poder, questiona as justificações internas que levam à dominação de uns sobre os outros. Weber identifica, pois, três fundamentos de legitimidade: a tradicional (patriarcal patrimonial), a carismática e a legal (racional burocrática). Segue a classificação weberiana:

Inicialmente, a autoridade do 'passado eterno', ou seja, dos costumes santificados pela validez imemorial e pelo hábito, enraizado nos homens, de respeitá-los. Assim se apresenta o 'poder tradicional', que o patriarca ou o senhor de terras exercia antigamente. Em segundo lugar, existe a autoridade que se baseia em dons pessoais e extraordinários de um indivíduo (carisma) - devoção e confiança estritamente pessoais depositadas em alguém que se diferencia por qualidades prodigiosas, por heroísmo ou por outras qualidades exemplares que dele fazem chefe. (...) Em suma, existe a autoridade que se impõe pela 'legalidade', pela crença na validez de um estatuto legal e de uma 'competência positiva, estruturada em regras racionalmente estabelecidas ou, em outras palavras, a autoridade fincada na obediência, que reconhece obrigações concernentes ao estatuto estabelecido. Assim é o poder, tal qual o exerce o 'servidor do Estado' atualmente e como o exercem todos os detentores do poder que dele se aproximam sob esse aspecto. ${ }^{156}$

No ordenamento jurídico brasileiro, a subordinação ao poder do empregador, decorrente do contrato de trabalho, é essencialmente jurídica. Mas as relações econômicas

\footnotetext{
${ }^{156}$ WEBER, Max. Ciência e política: duas vocações. Trad. Jean Melville. São Paulo: Martin Claret, 2002. p. 61.
} 
sustentaram-se, de forma subjacente, sob o poder patrimonial com contornos de paternalismo.

Richard Sennett esclarece que o patrimonialismo depende da existência de status, bens imóveis ou dotes, ou seja, algo estável para herdar ${ }^{157}$. A sociedade feudal e o absolutismo sustentavam essa estrutura patrimonial. Conforme Sennett explica, Locke acreditava que, uma vez superado o patrimonialismo, "a liberdade dos adultos fora da família aumentaria", mas "ele e outros idealistas liberais não previram que o que era passível de ser materialmente destruído podia ser reconstruído na imaginação: em metáforas ligando o pai ao patrão, o pai e o líder" ${ }^{158}$.

Assim, a partir do modelo de Estado de Direito, o poder, traduzido pelo ideal burguês, manifestar-se-ia apenas formalmente por meio da dominação burocrática. Mas o paternalismo também fez-se presente como forma de dominação, a partir da associação do empregador à figura de pai: "uma legitimação do poder fora da família, através do apelo aos papéis exercidos dentro dela" ${ }^{159}$.

O empregador apresentava-se como protetor do universo em que o trabalho era executado, mas não assegurava a "seus filhos" (empregados) um lugar estável no mundo $^{160}$. Esperava-se com isso a lealdade de um filho (empregado) em relação ao pai (empregador) e, consequentemente, a coesão comunitária que traria altos índices de produtividade ${ }^{161}$. Tratou-se, portanto, de um discurso extremamente valioso para consolidar o poder do empregador frente ao empregado, com base em um referencial de relação já consolidado e plenamente legitimado.

As estruturas e as funções econômicas impuseram (e impõem) sua base de referência e, muitas vezes, reproduziram (e reproduzem) um quadro de violência. A História é prodigiosa em demonstrar tal realidade fática. A título de ilustração e em razão do tema desenvolvido, cabe apontar o cenário de opressão a que foram submetidos os trabalhadores nos primórdios da Revolução Industrial do século XVIII. Amauri Mascaro Nascimento ilustra o quadro de indignidade das condições de trabalho subordinado, no fim do século XVIII:

\footnotetext{
${ }^{157}$ SENNETT, Richard. Autoridade. Trad. Vera Ribeiro. Rio de Janeiro: Record, 2001. p. 77.

${ }^{158}$ Id. Ibid., p. 82.

${ }^{159}$ Id., loc. cit.

${ }^{160}$ Id. Ibid., p. 78.

${ }^{161}$ Id. Ibid., p. 88.
} 
O industrial de algodão Samuel Oldknow contratou, em 1796, com uma paróquia a aquisição de um lote de 70 menores, mesmo contra a vontade dos pais. Yarranton tinha, a seu serviço, 200 meninas que fiavam em absoluto silêncio e eram açoitadas se trabalhavam mal ou demasiado lentamente. Daniel Defoe pregava que não havia nenhum ser humano de mais de quatro anos que não podia ganhar a vida trabalhando. Se os menores não cumpriam as suas obrigações na fábrica, os vigilantes aplicavam-lhes brutalidades, o que não era geral, mas, de certo modo, tinha alguma aprovação dos costumes contemporâneos. Em certa fábrica, a cisterna de água pluvial era fechada à chave. ${ }^{162}$

Maria Celeste C. Leite dos Santos, em seu estudo sobre o poder jurídico e a violência simbólica, expõe a dificuldade de se exercer o poder sob coação. Para a autora, “o ato de coação é o limite do poder, é o momento em que o poder desaparece”. Em uma análise sistêmica, a autora conclui que, ao aproximar-se da coação, o poder exclui a opção de escolha pelo outro. Afinal, explica Maria Celeste C. Leite dos Santos, co-agir é agir pelo outro, agir no lugar do outro, de sorte que: "O coagido age aparentemente apenas, quando é na realidade um instrumento do coator". 163

Quando a coação não pôde sustentar a ordem capitalista, passou-se ao exercício da violência simbólica. Como alerta Maria Celeste C. Leite dos Santos: "ter poder na relação de comunicação não significa subjugar o outro, mas significa neutralizar o outro, o destinatário". Conforme escreve a autora, o destinatário continua tendo várias possibilidades de ação, mas estas possibilidades são neutralizadas de tal maneira que apareça uma só, embora as demais não desapareçam ${ }^{164}$.

A noção de liberdade foi construída sob o referencial da violência simbólica: como se é obrigado a trabalhar por força das necessidades, é por conta dessa fragilidade que o homem se submete a uma nova forma de servidão que foi decorada com o nome de "liberdade", já que é diferente do quadro histórico anterior ${ }^{165}$. Essa é uma descrição diante

\footnotetext{
${ }^{162}$ NASCIMENTO, Amauri Mascaro. Curso de direito do trabalho. 14. ed. São Paulo: Saraiva, 1997. p. 11.

${ }^{163}$ SANTOS, Maria Celeste C. Leite. Poder jurídico e violência simbólica: problemas do poder, na obra póstuma de Hans Kelsen “Allgemeine Theorie Der Normen”. São Paulo: Cultural Paulista, 1985. p. 152-153. ${ }^{164}$ Id. Ibid., p. 153.

${ }^{165}$ AUGER, Jean-Baptiste Amand. Les lois de la nature e les lois sociales. Lyon: P.M. Perrelon, 1883. p. X. Stephen Holmes e Cass R. Sunstein destacam que os filósofos costumam diferenciar liberdade e o valor da liberdade: "Liberdade tem pouco valor se aqueles que realmente a tem carecem de recursos para tornar efetivos seus direitos. Liberdade para contratar um advogado significa pouco se todos os advogados cobrarem honorários, se o Estado não ajudar e se você não tem dinheiro. O direito à propriedade privada, uma importante parte da liberdade, significa pouco se você não tem recursos para proteger o que tem e a polícia é indisponível". (HOLMES, Stephen; SUNSTEIN, Cass R. The cost of rights: why liberty depends on taxes. New York: Norton \& Co., 1999. p. 20).
} 
dos acontecimentos que se sucederam ao triunfo e consolidação do capitalismo como modo de produção $^{166}$.

Se parece certo que os fortes podem elaborar leis para tentar legitimar seus atos ${ }^{167}$, também não é desarrazoado afirmar que as ideias reputadas falaciosas, formatadas para atender interesses parciais e que por vezes imprimem formas de violência, acabam por alimentar a cobrança pelos propósitos declarados, mas não atingidos, que pretendem justificar a existência de tais leis. A noção de direitos humanos passou por um questionamento social: como assegurar a liberdade sem direito a voto? Como assegurar a igualdade sem direito à vida? Ou seja, como tornar eficazes os direitos humanos, a ponto de garantir a todos a sua condição de seres humanos preservada por esses direitos?

As normas trabalhistas que passam a ser paulatinamente reconhecidas no âmbito dos ordenamentos jurídicos internos, com destaque para o fenômeno conhecido por “Constitucionalismo Social”, são mecanismos de contenção dos abusos praticados pelos empregadores, sob os auspícios de uma "pseudoliberdade" legalmente reconhecida. Portanto, o reconhecimento dos direitos de natureza trabalhista como direitos fundamentais exprimem a sua imprescindibilidade para a garantia da dignidade humana.

Mas como apreender o sentido da dignidade humana? Aliás, como esse sentido pode ser construído ou ser concebido? Conforme aponta Cristiano Carvalho, "toda interpretação dos direitos individuais se modifica, a depender das lentes com que é

\footnotetext{
${ }^{166}$ Interessante notar que não apenas o capitalismo foi prodigioso na concepção da violência simbólica, mas, de maneira mais objetiva e explícita, a violência do modo de produção stakhanovista nos países sob o regime socialista também submeteu o trabalhador à nova "servidão", por meio da propaganda política. Como explica Jorge Ferreira, para cumprir o plano qüinqüenal imposto pelo governo soviético, era exigida dos trabalhadores alta produção em exíguo espaço de tempo. A fim de legitimar essa política, o goveno se valeu de um novo método de trabalho, que ficou conhecido como stakhanovismo. Alexey Stakhanov era um trabalhador de minas, que ganhou fama por ter, em 31 de agosto de 1935, extraído 102 toneladas de carvão em 5 horas e 45 minutos. O feito de Stakhanov passou a ser o modelo a ser seguido pelos demais trabalhadores da União das Repúblicas Socialistas Soviéticas. Conforme descreve Jorge Ferreira, sob o método stakhanovista, "mobilizando os trabalhadores e utilizando o recurso da 'emulação socialista', o partido lançava desafios de produtividade, tensionando-os e extenuando-os até o limite". (FERREIRA, Jorge. URSS: mito, utopia e história. Revista Tempo, Rio de Janeiro, v. 3, n. 5, p. 80, 1998).

${ }^{167}$ AUGER, Jean-Baptiste Amand. op. cit., p. XI. A apropriação da mão-de-obra pelo empregador induz, no ideário capitalista, à afirmação da propriedade do próprio corpo do trabalhador, manifestada nessa hipótese na disposição das capacidades físico-biológicas do ser humano ao interesse da atividade econômica. Nesse contexto, Karl Marx apresenta um exemplo de como as estruturas jurídicas colaboraram para legitimar a exploração e o domínio sobre o trabalho humano: "O primeiro caso passa-se em Sheffield, em fins de 1866. Um operário havia-se empregado por dois anos numa usina metalúrgica. Por causa de uns desentendimentos com o patrão, deixou a fábrica dizendo que de modo algum voltaria para esse fabricante. Acusado de ruptura de contrato, foi condenado a dois meses de prisão." (MARX, Karl. Da manufatura à fábrica automática. In: GORZ, André. Crítica da divisão do trabalho. Trad. Estela dos Santos Abreu. São Paulo: Martins Fontes, 2001. p. 33).
} 
realizada". Exemplo trazido pelo referido autor é o da interpretação da igualdade. Sob o referencial do Estado de Direito liberal, a igualdade dá-se perante a lei, que vale para todos, respeitando-se os limites da desigualdade. Por outro lado, sob a perspectiva do Estado Social Democrático, a igualdade é material, ou seja, promove-se a igualdade quando há possibilidade de acesso às mesmas condições socioeconômicas predeterminadas $^{168}$.

Se parece improvável definir os contornos precisos de uma noção de dignidade, é fundamental admitir a importância e as limitações dos recuros técnico-científicos disponíveis (paradigma da racionalidade científica), pois diante da multiplicidade de padrões de referência, a dignidade é ela mesma representação da complexidade das relações jurídico-sociais, dentre elas, as de trabalho. À medida que a dignidade humana é fundamento para a afirmação dos direitos humanos - os quais reconhecidos constitucionalmente passam exatamente à condição de direitos fundamentais - , à racionalidade econômica e metricamente calculável surgem elementos não passíveis de adequação irrestrita à óptica técnicocientífica. Os direitos humanos são resultado da inquestionável constatação da presença de pluralidade de interesses, do conflito, da instabilidade das relações. Por isso, a afirmação jurídica de conceitos mais maleáveis abre espaço para o campo da discussão sobre o sentido e o limite desses conceitos.

Assim, a teoria dos direitos humanos é reflexo do reconhecimento da complexidade social, que extrapola a visão de mundo mecanicista e, portanto, não-linear. Essa nova visão da realidade, conforme explica Fritjof Capra, "baseia-se na consciência do estado de interrelação e interdependência essencial de todos os fenômenos - físicos, biológicos, psicológicos, sociais e culturais" ${ }^{\prime 169}$. Refere-se, portanto, a uma nova concepção de mundo, em termos de atividade científica.

O impacto da complexidade no universo sistêmico jurídico é a questão que se propõe a discorrer no item a seguir.

\footnotetext{
${ }^{168}$ CARVALHO, Cristiano. Teoria do sistema jurídico: direito, economia, tributação. São Paulo: Quartier Latin, 2005. p. 238.

${ }^{169}$ CAPRA, Fritjof. O ponto de mutação: a ciência, a sociedade e a cultura emergente, cit., p. 259.
} 


\subsection{O reconhecimento jurídico da complexidade: a consagração dos direitos humanos}

Após descrever os problemas originados pelo modelo de certeza, com pressupostos como homem abstrato e eficiência absoluta da razão humana, destaca-se que não é possível manter parâmetros estritamente matemáticos para definir as relações humanas. MarieLouise Von Franz afirma que "esse método leva ao conhecimento científico, mas não a uma compreensão do ser humano real. Disso resulta um quadro racional cada vez mais irreal, no qual a pessoa figura apenas como uma espécie de fenômeno marginal". ${ }^{170}$

Como foi visto, a dinâmica da sociedade, em razão da sua própria complexidade, originalmente era traduzida por mitos. A complexidade é reduzida, por meio do fracionamento do objeto a ser estudado.

Reduzir a complexidade é desvincular a infinidade de conflitos interligados a um determinado contexto a ser observado. O exemplo que se explora nesse estudo são as relações de trabalho subordinado, nas quais uma questão aparentemente técnica - redução de riscos de acidentes de trabalho - extrapola os contornos da discussão de caráter objetivo, para adentrar no cerne da compreensão de como as partes envolvidas assimilam o conceito jurídico de dignidade. A noção de dignidade, conforme se propõe nesse estudo, perpassa o olhar das partes envolvidas na relação de trabalho subordinado.

As normas positivadas devem prescrever comandos objetivos e precisos para regular as condutas. Porém as características imprimidas a essas normas são pouco adequadas na seara dos direitos humanos. Os direitos humanos, conforme já foi mencionado, pressupõem um referencial de complexidade. O positivismo, conforme escreve Marcus Orione Gonçalves Correia, "é extremamente insuficiente para a leitura dos direitos humanos"171. A teoria moderna do homem promoveu a perda do centro intelectual, a partir do fracionamento e simplificação dos saberes, distanciando-se da investigação das necessidades e reações típicas da natureza humana:

Teólogos, cientistas, políticos, sociólogos, biólogos, psicólogos, etnólogos e economistas, cada um abordou o problema [unidade da natureza humana] a partir do seu

\footnotetext{
${ }^{170}$ FRANZ, Marie-Louise von. C. G. Jung: seu mito em nossa época. São Paulo: Cultrix, 1997. p. 206.

${ }^{171}$ CORREIA, Marcus Orione Gonçalves. Por uma metodologia dos direitos humanos: uma análise na perspectiva dos direitos sociais. Revista do Departamento de Direito Trabalho e Seguridade Social da Faculdade de Direito da Universidade de São Paulo, São Paulo, v. 2. n. 4, p. 123, jul./dez. 2007.
} 
próprio ponto de vista. (...) Que esse antagonismo de ideias não é meramente um grave problema teórico e sim uma ameaça iminente a toda extensão de nossa vida ética e cultural não admite qualquer dúvida. (...) A menos que consigamos achar um fio de Ariadne que nos conduza para fora deste labirinto, não teremos qualquer compreensão real do caráter geral da cultura humana; continuaremos perdidos em uma massa de dados desconexos e desintegrados que parecem carecer de toda unidade conceitual. ${ }^{172}$ [grifo nosso]

Nessa esteira, prossegue Marcus Orione Gonçalves Correia para enfatizar que o estudo dos direitos humanos não prescinde de um olhar para o intercâmbio entre as diversas ciências do conhecimento humano. Aliás, segundo o mencionado autor, "não há compreensão possível dos direitos humanos sem compreensão, só para citar alguns exemplos, de conceitos antropológicos, sociológicos, filosóficos. A causa além da causalidade meramente normativa" ${ }^{173}$.

Por que não somar aos sociólogos, etnólogos, economistas etc. os cientistas jurídicos? Admitir a possibilidade de intercâmbio entre as disciplinas e a efetivação de contribuições entre elas é aceitar a interdisciplinaridade ${ }^{174}$ :

O diálogo interdisciplinar é a articulação de disciplinas, de culturas, de conhecimentos e de seres humanos. Mais que a articulação de capítulos de livros ou de livros inteiros, é a articulação de textos e contextos sociais e culturais, e de autores-leitores para a construção de mediações entre realidades e utopias ${ }^{175}$.

A interdisciplinaridade e o reconhecimento da complexidade permitem avaliar como a dinâmica de poder se processa no conjunto das relações sociais como um todo. Quando o exercício do poder se dá pelo uso da força, uma verificação objetiva permite extrair as características desse poder. Mas o poder, a partir da evolução das estratégias técnico-científicas de dominação, manifesta-se pela imposição de modelos e conceitos, ou seja, por sua força discursiva. Logo, o exercício da força não é explícito, mas é mascarado no discurso refletido na estrutura, no processo e nas funções do sistema, que tornam abstratas realidades complexas. Exemplo disso são a inevitabilidade dos contratos precários e o discurso da empregabilidade, decorrências do fenômeno da flexibilização: "Hoje em dia presume-se, por exemplo, que as pessoas são responsáveis pela criação do

\footnotetext{
${ }^{172}$ CASSIRER, Ernest. op. cit., p. 41-42.

${ }^{173}$ CORREIA, Marcus Orione Gonçalves. op. cit., p. 123.

${ }^{174}$ VASCONCELLOS, Maria José Esteves. op. cit., p. 114.

${ }^{175}$ GONZÁLEZ CASANOVA, Pablo. op. cit., p. 59-60.
} 
próprio significado de suas vidas. Qualquer que se esquive a essa terrível liberdade será julgado dependente e psicologicamente imaturo". ${ }^{176}$

Impõe-se, assim, uma padronização de comportamentos, à qual nem sempre o indivíduo consegue se adaptar. Aliás, não se questiona se os indivíduos dispõem de elementos internos capazes de operar a adaptação, sem comprometimento da sua natureza humana. Isso conduz, mais uma vez, à abstração do ser humano e a influência do método científico fáustico $^{177}$.

Observa-se, enfim, que a abstração da figura humana representa a "crise do sujeito", como já enunciava Max Weber, em "A ética protestante e o espírito do capitalismo", de 1905. Ao converter a razão em instrumento para disciplinar e organizar a ação humana (racionalização), o cogito ergo sum (indivíduo compacto e homogêneo) cartesiano é suplantado pela racionalidade, essa como parte da estrutura constitutiva dos laços sociais. A relação não se dá mais entre indivíduo-sociedade, mas entre racionalidade e forma de ação ${ }^{178}$.

O que Weber postula como a razão da modernidade é a racionalidade econômica do capitalismo: maximização do autointeresse com redução ou eliminação dos riscos indesejáveis. A maximização do autointeresse na sociedade capitalista pauta-se na utilização de técnicas e instrumentos que permitam o maior benefício com menor custo. Em termos de aproveitamento do recurso "trabalho humano", a divisão técnica, com fragmentação das tarefas no processo produtivo, representou uma otimização da organização do trabalho. Esse mecanismo é fruto da burocratização das relações de trabalho, a partir do que o enfoque se concentra no cumprimento objetivo das tarefas, de acordo com a administração e gerência técnicas das atividades produtivas. Com isso,

\footnotetext{
${ }^{176}$ HOLLIS, James. op. cit., p. 77.

177 “O peculiar ambiente que constitui o cenário do último ato do Fausto - o imenso canteiro de obras, ampliando-se em todas as direções, em constante mudança e forçando os próprios figurantes a mudar também - tornou-se o cenário da história mundial em nosso tempo. Fausto, o Fomentador, ainda apenas um marginal no mundo de Goethe, sentir-se-ia completamente em casa no nosso mundo. Goethe apresenta um modelo de ação social em torno do qual gravitam sociedades avançadas e atrasadas, ideologias capitalistas e socialistas. Mas Goethe insiste em que se trata de uma terrível e trágica convergência, selada com o sangue das vítimas, articulada com seus ossos, que têm a mesma cor e a mesma forma em qualquer parte. $\mathrm{O}$ processo de desenvolvimento que os espíritos criativos do século XIX conceberam como uma grande aventura humana tornou-se, em nossa era, uma necessidade de vida ou morte para todas as nações e todos os sistemas sociais do mundo. Em consequência disso, autoridades fomentadoras, em toda parte, acumularam em suas próprias mãos poderes imensos, fora do controle e muito frequentemente letais". (BERMAN, Marshall. Tudo o que é sólido se desmancha no ar. Trad. Carlos Felipe Moisés e Ana Maria L. Ioriatti. São Paulo: Companhia das Letras, 2007. p. 94-95).

${ }^{178}$ MARRAMAO, Giacomo. Poder e secularização: as categorias do tempo. Trad. Guilherme Alberto Gomes de Andrade. São Paulo: Ed. UNESP, 1995. p. 186.
} 
promove-se a desumanização (ou "reificação") do trabalho. A burocratização acaba por “despersonalizar" as relações.

Ao imprimir o racionalismo como paradigma e a presença do indíviduo livre e maximizador de seus interesses, estabelecem-se objetivos fragmentados e parciais, inspirados no modelo de divisão de tarefas, porém com impacto na vida social. Por exemplo, impõe-se a busca por uma atividade "gratificante", sem saber ao certo qual seria o critério para definir a atividade como tal. Como acentua Adolf Guggenbuhl-Craig, "a questão de um sentido mais abrangente é ignorada" e prossegue o autor relatando alguns dos objetivos perseguidos: "ganhar dinheiro, cumprir com os deveres familiares, conquistar certo status social, ajustar-se ao sistema, exercer com sucesso uma profissão, cuidar da saúde etc." ${ }^{179}$ [grifo nosso]

Essa racionalização, na concepção weberiana, não expropria violentamente, selvagemente o produto do trabalho social, mas estabelece condições para que uma ética seja incorporada na sociedade. Weber propôs dessa maneira a superação da causalidade única na análise dos processos sociais ${ }^{180}$ e encontrou na religiosidade o espírito do capitalismo moderno. Em Weber, o capitalismo moderno, ao se valer da racionalidade no tratamento dos fatores de produção, distinguiu-se do capitalismo tradicional, focado na especulação e no oportunismo. ${ }^{181}$ A evolução do capitalismo passou do ascetismo para a atual corrida desenfreada em busca de bens materiais. O resultado foi a vitória do capitalismo, sustentado por uma base mecânica, que dispensa o abrigo do espírito religioso. ${ }^{182}$ Embora o capitalismo na atualidade prescinda de um referencial voltado para elevados valores culturais (a exemplo do ascetismo religioso), o espírito do capitalismo continua comandando um processo de crescente racionalização do trabalho "que determinam formas cada vez mais racionais de conduta, tanto no trabalho quanto na vida social como um todo, ainda que recobertas por práticas diferentes daquelas indicadas por Weber no início do século XX". ${ }^{183}$

\footnotetext{
${ }^{179}$ GUGGENBÜHL-CRAIG, Adolf. $O$ abuso do poder na psicoterapia e na medicina, serviço social, sacerdócio e magistério. Trad. Roberto Gambini. São Paulo: Paulus, 2004. p. 127.

${ }^{180}$ VILELA, Sérgio Luiz de Oliveira. Racionalização e globalização: uma leitura a partir de Max Weber. Raízes: revista de ciências sociais e econômicas, Campina Grande, ano 18, v. 19, p. 47, 1999. Disponível em: <www.ufcg.edu.br/ raizes/artigos/Artigo_43.pdf>. Acesso em: 01 ago. 2010.

${ }^{181}$ Id. Ibid., p. 38.

${ }^{182}$ Id. Ibid., p. 44.

${ }^{183}$ Id. Ibid., p. 46.
} 
A peculiaridade da realidade contemporânea é a dissociação da ideia de que a dominação é exclusivamente exercida pelo poder estatal. A dominação é exercida de maneira simbólica e é possível determinar um centro de poder de onde se origina.

O discurso da automação traduz uma forma de dominação. Com a aquisição de bens tecnológicos pelos empresários, os trabalhadores atualmente encontram na automação um fator de perda de postos de trabalho e de consequente desemprego. Clama-se pela qualificação dos trabalhadores, como alternativa para reinserção no mercado de trabalho. Mas teriam os trabalhadores acesso e capacidade para acompanhar a velocidade dos avanços tecnológicos que estão em curso e que podem exterminar sua possibilidade de conseguir um novo emprego? Onde estariam a autonomia e a independência do ser vivo? Por essa razão, o papel do sistema dos direitos fundamentais é indispensável para conferir legitimidade ao exercício dos poderes na dinâmica das relações de trabalho subordinado.

Observa-se a postura do legislador constituinte que, ao reconhecer a realidade díspare do empregado e do empregador, enunciou como direito fundamental, no artigo $7^{\circ}$, inciso XXVII, da Constituição da República Federativa do Brasil, a proteção do trabalhador em face da automação, na forma da lei. Entretanto, essa lei, mesmo após mais de vinte anos da promulgação da Constituição, ainda não foi elaborada.

Daí questiona-se a capacidade do Estado para garantir o exercício e a proteção de direitos assegurados pela sua própria Constituição, diante do universalismo dos direitos e dos escassos recursos. Tais questões geram instabilidade no quadro social, porque as ações realizadas na esfera individual produzem consequências dentro de um contexto de coletividade e de risco.

Em uma sociedade marcada pela complexidade, o Direito, portanto, enfrenta grandes desafios decorrentes do modelo em que se inspirou: o individualismo, a noção de propriedade e o contrato como resultado do exercício de uma razão plena, manifestada por meio da autonomia da vontade.

Com a valorização dos direitos humanos - dentre eles os direitos juslaborais que visam à dignidade nas relações de trabalho - , inicia-se a construção de um projeto contra a degeneração da existência humana promovida não apenas pelo exercício do poder pelo Estado, mas também em face do poder exercido pelos próprios entes que compõem a sociedade. 
A passagem do individual para o coletivo fomenta a discussão das proposições do paradigma da modernidade. A abordagem do valor do coletivo é o convite para contemplar o "viver em livre comunicação um com o outro", como formula Tércio Sampaio Ferraz Júnior, a fim de permitir ao ser humano se reconhecer como um agente/paciente, numa rede de conexões. ${ }^{184}$

\subsection{O conflito de racionalidades e a coerência valorativa do sistema constitucional}

Gérard Fourez defende que "a ciência é um saber ligado a grupos sociais determinados". De acordo com essa perspectiva e segundo o autor, a ciência moderna está atrelada à representação do mundo própria da burguesia, cujos traços marcantes seriam: a) um distanciamento da realidade social como se dela não fizesse parte (a burguesia "se sente exterior ao mundo"); b) objetivo de exploração e de dominação do meio ambiente (social, natural) por meio de técnicas científicas de previsão e cálculo ${ }^{185}$.

O exemplo que Fourez enfoca é o da medicina científica. O interesse da medicina científica, de acordo com o estudo realizado pelo autor, está entre a extração do mal e a cura do doente. Dessa forma, a medicina científica - determinada pela prática médica inicialmente dirigiu-se a pacientes capazes de se cuidar e de pagar pelos medicamentos. As prioridades, portanto, escolhidas não se dirigem ao ser humano, mas à doença: "prioridade da cura sobre a higiene; prioridade do corpo sobre a psicologia; prioridade das especializações sobre a medicina geral; prioridade da cura sobre o bem viver e assim por diante" ${ }^{" 186}$. E as indagações que Fourez deixa remetem à ideia de eficácia dos direitos fundamentais: "O que pode fazer um especialista em operações cardíacas quando a maioria da população sofre de paralisias intestinais? Para que serve um diagnóstico bem preciso se ele só pode ser aplicado a uma minoria?"187.

O problema estrutural da medicina científica poderia ser contornado se, ao invés da cura, fosse priorizada a prevenção e atribuído importância à educação e aos valores da vida. Precisamente como destaca Fourez, um enfoque sobre os valores da vida afastaria a

\footnotetext{
${ }^{184}$ FERRAZ JÚNIOR, Tércio Sampaio. Estudos de filosofia do direito: reflexões sobre o poder, a liberdade, a justiça e o direito, cit., p. 137.

${ }^{185}$ FOUREZ, Gérard. op. cit., p. 163 e 190.

${ }^{186}$ Id. Ibid., p. 114.

${ }^{187}$ Id. Ibid., p. 116.
} 
ideia do indivíduo "abstrato", "separado da realidade afetiva e social em que vive, mas sobre uma pessoa integrada à sua vizinhança, ao seu meio de trabalho, à sua região e ao universo" ${ }^{188}$. O que Gérard Fourez propõe, ao estudar a filosofia da ciência, é a valorização do ser humano. Assim, como pondera Pablo González Casanova, não se trata de ignorar o legado da pesquisa filosófica e científica anterior, mas, a partir desse arcabouço, propor uma ação científica e humanística ${ }^{189}$.

O desafio de propor o diálogo entre os clássicos e os contemporâneos envolve o confronto de racionalidades, ou seja, não há um modelo único para compreender e regular a realidade. Celso Fernandes Campilongo destaca que a "complicada convivência" entre o Estado de Direito (formal e legalista) com o Estado de Bem-Estar Social (material e teleológico) demanda o recurso a "novas categorias cognitivas da parte do intérprete". O autor cita, como exemplos, a inclusão do debate sobre a função social da propriedade, os novos tipos de contratos, a responsabilidade civil visa com o instrumento de redistribuição de recursos no âmbito do direito civil. Esses exemplos demonstram a tentativa de reconstruir instrumentos jurídicos a partir de conceitos "tomados de empréstimo da Economia, da Sociologia e de outros ramos do conhecimento",190

O Direito do Trabalho é fruto do Estado Social Democrático de Direito. Esse modelo de Estado, segundo Celso Fernandes Campilongo, "atua com base numa dupla racionalidade: uma presidida pelo princípio da legalidade; outra, orientada pelo critério da eficiência", de maneira que "grande parte da incoerência normativa decorre da estratégia adotada para o equilíbrio dessas racionalidades"191.

Brunela Vieira De Vicenzi afirma que a crescente complexidade das racionalidades sociais é responsável pela colisão das pretensões individuais diferentes, além de expressar as contradições sociais muito profundas em setores da sociedade mundial que colidem entre si ${ }^{192}$. Formula-se, assim, o problema: até que ponto os conceitos (re)construídos com base em critérios econômicos, sociais, políticos etc. são assimilados pelo sistema jurídico por adaptação ou promovem a ruptura da estrutura sistêmica do Direito. A atenção aqui

\footnotetext{
${ }^{188}$ FOUREZ, Gérard. op. cit., p. 116-117.

${ }^{189}$ GONZÁLEZ CASANOVA, Pablo. op. cit., p. 59.

${ }^{190}$ CAMPILONGO, Celso Fernandes. Os desafios do Judiciário: um enquadramento teórico. In: FARIA, José Eduardo (Org.). Direitos humanos, direitos sociais e justiça. São Paulo: Malheiros Ed., 2005. p. 46.

${ }^{191}$ Id. Ibid., p. 43.

${ }^{192}$ DE VINCENZO, Brunela Vieira de. Guinada semântica: indivíduo, pessoa, individualismo, individualização e sujeito de direitos fundamentais. In: NALINI, José Renato; NALINI, Angélica Carlini (Orgs.). Direitos humanos e formação jurídica. Rio de Janeiro: Forense, 2010. p. 101.
} 
centra-se no sistema juslaboral: em face das transformações do mundo do trabalho - com destaque para as mudanças conjunturais econômicas -, como se mantêm os valores inerentes à proteção da saúde e segurança do trabalhador? Ou melhor, como "combinar os tradicionais critérios técnico-formais com outros de caráter axiológico"? ${ }^{193}$ Se a sociedade complexa não admite um modelo único, há convivência de múltiplos paradigmas ou a noção de paradigma mesmo resta comprometida?

Apresentar uma resposta para as indagações acima não é objetivo deste trabalho, e sim suscitá-las, pois o Direito do Trabalho nasce no cenário de reconhecimento dos direitos fundamentais, o que significa que o paradigma que o inspirou se pauta mais no substrato axiológico do que no legalista. Basta mencionar que um dos princípios basilares do Direito do Trabalho é o princípio da norma mais favorável. Dada a complexidade da realidade em que o Direito está imerso, a manutenção do sistema depende principalmente da sua coerência valorativa (princípios, valores).

A formulação de uma Teoria Geral de Direitos Fundamentais pressupõe uma epistemologia da complexidade, presente no pensamento sistêmico. Quando se admite uma norma mais favorável que outra ou mesmo ponderam-se interesses, aceita-se o paradigma de complexidade,

em cuja epistemologia sobreleva a figura do observador (o juiz, no caso do Direito). Esse paradigma permite o 'retorno do terceiro excluído' ao contrapor a lógica formal a lógica jurídica da argumentação racional, usando em favor dos valores do sistema a força criativa inerente aos 'paradoxos', entre estes a existência de princípios constitucionais conflitantes. ${ }^{194}$

Em um universo de complexidade, a sociedade existe como resultado da redução da própria complexidade. Sem sociedade, surge a denominada situação de dupla contingência, ou seja, ausência de previsibilidade:

Contingente é aquilo que não é nem necessário nem impossível, apenas possível: espera do 'inesperado' até que surja um princípio de ordem, não há nenhuma regra de previsibilidade de comportamento pessoal, nada é previsível, tudo é possível. Não há expectativas, não há comunicação: há

\footnotetext{
${ }^{193}$ FARIA, José Eduardo. As transformações do Judiciário em face de suas responsabilidades sociais. In:__ (Org.). Direitos humanos, direitos sociais e justiça. São Paulo: Malheiros Ed., 2005. p. 63.

${ }^{194} \mathrm{DANTAS}$, David Diniz. Interpretação constitucional no pós-positivismo: teoria e casos práticos. São Paulo: WCV Ed., 2004. p.122.
} 
desordem não rompida, unmarked space ou espaço sem limites definidos ou sinalizações. ${ }^{195}$

Esse cenário aproxima-se à representação do estado de natureza hobbesiano, em que o homem seria o lobo do homem. A dupla contingência cede espaço à transformação da possibilidade genérica em possibilidade concreta, isso significa que, no momento em que um indivíduo realiza uma escolha, cabe ao outro indivíduo aceitá-la ou recusá-la. Surge daí a comunicação. Constitui-se, assim, uma sociedade não de indivíduos ou consciências individuais, mas de comunicação. A sociedade é um sistema social fechado, que estabelece seus próprios limites e constitui seus próprios elementos, a partir da comunicação. ${ }^{196}$

O excesso de comunicação e de comportamentos pode travar um sistema, o que torna inevitável uma maior redução das complexidades por meio dos subsistemas. Os subsistemas sociais constituem-se fundamentalmente em razão da sua função, a qual determina uma área da complexidade social. É o caso do Direito:

só é Direito aquilo que se encontra nos limites semânticos configurados pelo próprio sistema jurídico. A complexidade é reduzida, já que um enorme campo de possibilidades (complexidade) fica à margem do Direito (moral, ciência, relações íntimas, etc.). Mas ao mesmo tempo um número ainda maior de possibilidades pode ser submetido ao exame de sua juridicidade: atualização sem fim de possibilidades. ${ }^{197}$ [grifo nosso]

Assim, o ordenamento jurídico não é rígido e inflexível. A importância dos valores e princípios - especialmente os presentes na Constituição - repousa exatamente na flexibilidade necessária que conferem ao sistema, sem que esse sofra ruptura.

O sistema constitucional sobrevive da coerência valorativa, que permite qualificar o sistema como teleológico. A coerência valorativa

do pensamento teleológico não está em criar uma apriorística e autoritária ordem hierárquica de princípios e valores, mas na postura do juiz que ao concretizar um princípio deve 'pensar todas as consequências até o fim', o que implicará, muitas vezes, ponderação com outros princípios e valores do sistema. Assim, o sistema teleológico garante a 'coerência formal' ou a 'coerência valorativa' no plano pragmático. Será exatamente esse princípio de 'coerência valorativa pragmática' que

\footnotetext{
${ }^{195}$ DANTAS, David Diniz. op. cit., p. 137.

${ }^{196}$ Id. Ibid., p. 139.

${ }^{197}$ Id. Ibid., p. 140.
} 
fornecerá o critério objetivo capaz de dotar de racionalidade a prática das decisões dos casos difíceis. ${ }^{198}$

Nessa linha de raciocínio, vale mencionar a teoria da autopoiese. A autopoiese surge como resultado de uma pesquisa de Biologia, realizada por Humberto Maturana e de Francisco Varela, sobre como definir um sistema vivo. Os biólogos chilenos concluíram que a autonomia e a constância de uma certa organização das relações entre os elementos constitutivos do sistema definem a vida de cada sistema vivo individual.

Niklas Luhmann transpôs esse modelo biológico para as ciências sociais e três ideias merecem destaque, analisadas por David Diniz Dantas;

Primeiro: que o elemento base da sistematicidade dos subsistemas é a comunicação. Em relação ao Direito, esse elemento é o 'ato jurídico'.

Segundo: sistema com 'comunicação única' não possui sentido, não é sistema, pois não reduz complexidade. Todas as operações são autoreproduções. A unidade se define nesse fechamento autopoiético, não na estrutura ou no método. (...)

A terceira observação é que o Direito - à semelhança dos demais subsistemas sociais - se pressupõe e se reproduz a si mesmo: tanto sua unidade como sua organização, seus elementos constitutivos e suas fronteiras resultam, por redução de complexidade, de performances do próprio sistema. Não procedem nem da natureza, nem do ambiente. Conseqüentemente, todo Direito (legislativo, jurisprudencial ou contratual) é sempre Direito positivo. ${ }^{199}$

Surge assim a indagação, formulada por Daniel David Dantas: "Como o sistema auto-referencial trata a questão da justiça?”

E o autor responde, com base na teoria de Luhmann;

a noção de 'justiça' significa que, apesar da infinidade e diversidade de decisões e procedimentos, além das 'irritações' provocadas pelo meio social, o sistema consegue atingir um nível de 'coerência pragmática' que lhe possibilita continuar a existir. Um dos grandes desafios nas sociedades atuais é não sacrificar a coerência em virtude do aumento crescente de complexidade. ${ }^{200}$

\footnotetext{
${ }^{198}$ DANTAS, David Diniz. op. cit., p. 171.

${ }^{199}$ Id. Ibid., p. 143.

${ }^{200}$ Id. Ibid., p. 156.
} 
No caso do Direito do Trabalho, essa questão assume relevada importância, quando se percebe que as "irritações" provocadas pelo meio social podem comprometer a coerência valorativa do sistema. Mas ao garantir a valorização do trabalho humano e a existência digna (artigo 170, caput, da Constituição Federal da República Federativa do Brasil), a Constituição firma sua base de referência no campo das relações de trabalho subordinado. Interessante notar que o artigo 170 inaugura o Capítulo I do Título VII da Constituição Brasileira: "Dos Princípios Gerais da Atividade Econômica". O legislador converte para o interior do sistema jurídico elementos econômicos e "na ótica sistêmica de Luhmann quando esses elementos (da moral, política, religião, etc.) são os atos usados pelo Judiciário para justificar decisões, como por um 'toque de Midas' são convertidos em elementos do sistema jurídico". ${ }^{201}$

Sob a perspectiva luhmanniana, dessa maneira o Direito assegura sua função sobre os comportamentos que envolvem relações econômicas. E qual é a função do Direito? Para Luhmann, "a função do direito reside em sua eficiência seletiva, na seleção de expectativas comportamentais que possam ser generalizadas em todas as três dimensões [temporal, social e prática]"202

Em uma sociedade complexa, com vários sistemas e subsistemas, o Direito exerceria a função de reduzir complexidade na esfera de comportamentos. Sem adentrar nas implicações dessa assertiva na teoria luhmanniana, cabe destacar que o Direito garantiria uma generalização de expectativas comportamentais, que tornaria a viável a sociedade e vice-versa. ${ }^{203}$ Reduzir a complexidade e tornar o inesperado em expectável traduz a "segurança jurídica" possível em uma sociedade pautada por vários interesses e conflitos.

Como aponta Cristiano Carvalho, critica-se comumente a teoria luhmanniana em razão de terem como elementos comunicações e não indivíduos. Contudo, Carvalho explica que tal argumento não se sustenta, na medida em que esses críticos não vislumbram um sistema social em que inexistam indivíduos, "semelhante a um conceito de ‘família' que não considera os membros familiares”. A sofisticação da teoria de Luhmann está nessa premissa: "não há grupo social sem linguagem, sem comunicação". ${ }^{204}$

\footnotetext{
${ }^{201}$ DANTAS, David Diniz. op. cit., p. 156.

${ }^{202}$ LUHMANN, Niklas. Sociologia do direito I, cit., p. 116.

${ }^{203}$ Id. Sociologia do Direito II. Trad. Gustavo Bayer. Rio de Janeiro: Tempo Brasileiro, 1983. p. 59.

${ }^{204}$ CARVALHO, Cristiano. op. cit., p. 139.
} 
No mundo do trabalho, os diversos comportamentos dos indivíduos atrelam-se às interpretações atribuídas ao termo "trabalho". Essas variantes interpretativas correspondem à pluralidade de dimensões da vida humana (psicológica, biológica, social, política, econômica etc.) e evidenciam, não somente a complexidade semântica do termo "trabalho", mas a complexidade do universo humano. A escolha por qualquer dos vieses possíveis pertence, enfim, ao observador que analisa ${ }^{205}$.

Contudo, a proposta de enunciar as expectativas comportamentais pela via normativa não traduz plenamente a função do Direito em uma sociedade plural. A ideia de generalização não corresponde à pluralidade de discursos que caracteriza a sociedade pós(hiper)-moderna ${ }^{206}$. Inicialmente, a formalização do Direito não o protege da infiltração de racionalidades extralegais ${ }^{207}$. A formalização (por exemplo, pela codificação, pela generalização normativa) não mantém o Direito imune contra a colisão das diferentes racionalidades. Por essa razão, se não é possível garantir a integridade do sistema jurídico pela formalização e pela positividade, o risco é tentar promover a unidade do Direito por meios extralegais. A análise econômica do Direito corresponde a essa tentativa de minimizar as tendências autodestrutivas da sociedade, dando preferência ao discurso econômico. ${ }^{208}$ Contudo, a análise econômica também clama por ocupar o status de racionalidade universal e culmina na generalização, nem sempre atendendo aos propósitos e princípios fundamentais para a manutenção da sociedade. Ou seja, as sociedades modernas estão fragmentadas em práticas discursivas refratárias e inacessíveis umas às outras $^{209}$.

Diante disso, Gunther Teubner sugere uma abordagem weberiana para lidar com a pluralidade de discursos: transferir o enfoque do indivíduo para o discurso legal ${ }^{210}$. Teubner apresenta sua resposta para o que denomina o novo Direito dos conflitos. Para ele, a questão é a nova situação a que o Direito está exposto: não se trata mais de resolver

\footnotetext{
${ }^{205}$ BENDASSOLLI, Pedro Fernando. O ethos do trabalho: sobre a insegurança ontológica na experiência atual com o trabalho. 2006. Tese (Doutorado em Psicologia Social) - Instituto de Psicologia, Universidade de São Paulo, São Paulo, 2006. p. 13.

${ }^{206}$ Sobre a noção de sociedade pós-moderna e hipermoderna, ver entendimento de Gilles Lipovetsky, descrito no item 2.1.1. do Capítulo II deste trabalho.

${ }^{207}$ TEUBNER, Gunther; FEBBRAJO, Alberto. Autonomy and regulation in the autopoietic perspective: an introduction. In:________ State, law and economy as autopoietic systems: regulation and autonomy in a new perspective. Milano: Giuffrè, 1992. p. 156.

${ }^{208}$ Id. Ibid., p. 157.

${ }^{209}$ Id. Ibid., p. 7.

${ }^{210}$ TEUBNER, Gunther. Altera pars auditur: law in collision of discourses. In: RAWLINGS, Richard. Law, society and economy - Centenary Essays for the London School of Economics and Political Science, 18951995. Oxford: Oxford University Press, 1997. p. 157.
} 
conflitos internos ao próprio sistema jurídico, mas ter de decidir entre racionalidades conflitantes derivadas de diferentes discursos ${ }^{211}$.

O Direito deixa, assim, de se ocupar dos velhos conflitos interpessoais em que a clássica função era garantir o mútuo reconhecimento da autonomia, coibir o inadimplemento e compensar os danos mutuamente causados ${ }^{212}$.

O novo Direito dos conflitos seria um Direito de conflitos de discurso e só pode ser entendido como uma "cadeia de decisões definitivas" no sentido de Max Weber, no qual “o argumento legal 'passa por' diferentes racionalidades particulares que estão institucionalizadas no Direito, e chega até decisões nessas bases, sem resolver o conflito permanente"213. Teubner ressalta que, se essa óptica não satisfaz o desejo romântico de conciliar as diferenças na sociedade, ao menos contempla a pluralidade e pode conduzir a resultados mais adequados e aceitáveis ${ }^{214}$.

Dessa forma, ao invés de tentar encontrar uma teoria que declare o fundamento mais importante para o Direito com base em racionalidades particulares, há de se desenvolver uma teoria de colisões discursivas que calibre o direito precisamente para o enfrentamento com a pluralidade de racionalidades sociais ${ }^{215}$. Então, "a função do Direito seria analisar o infinito jogo de referências praticadas no cenário de pluralidade de pontos de observação e converter a tradução dessas referências em uma forma 'constitucional",216.

Não se podem olvidar as críticas à abordagem sistêmica, mas o que se propõe não é a adoção desta ou daquela teoria e sim o pensamento sistêmico, cujas premissas complexidade, instabilidade e subjetividade - se delineiam nas teorias sistêmicas. $\mathrm{O}$ essencial, para fins desse estudo, é reconhecer, com base no pensamento sistêmico, que os processos de controle existentes nas relações de trabalho subordinado decorrem de uma hierarquia estabelecida por diferentes níveis de organização, interligados por uma lógica discursiva (comunicação).

No cerne das relações de trabalho subordinado, o processo de tradução das referências econômicas, políticas e sociais em formato "constitucional" das relações de

\footnotetext{
${ }^{211}$ TEUBNER, Gunther. Altera pars auditur: law in collision of discourses, cit., p. 159.

${ }^{212}$ Id. Ibid., p. 161.

${ }^{213}$ Id. Ibid., p. 159.

${ }^{214}$ Id. Ibid., p. 160

${ }^{215} \mathrm{Id}$, loc. cit.

${ }^{216}$ Id. Ibid., p. 161.
} 
trabalho subordinado demanda, no momento da aplicação dos direitos fundamentais ${ }^{217}$, a observância do denominado princípio da norma mais favorável. Mas a ele soma-se a observação dos interesses e dos discursos, com vistas a chegar à decisão que melhor garanta a efetividade dos direitos fundamentais.

Contemplar os interesses envolvidos e a dinâmica dos discursos em conflito é aplicar a norma que não seja mais favorável a esse ou aquele indivíduo, mas a norma favorável à realização das funções do sistema de proteção dos direitos fundamentais. Gunther Teubner lembra que as normas são reconstituídas, no que tange o seu sentido, economicamente, politicamente e pedagogicamente, em uma segunda leitura realizada pelos respectivos discursos. Por essa razão, o referido autor entende que uma observação legal deve restringir as infinitas consequências, que tenham um impacto negativo sobre o ambiente discursivo do Direito. ${ }^{218}$

O princípio da norma favorável passa, então, a ser traduzido no formato constitucional como princípio da norma que promova a dignidade do trabalhador. A questão que se põe é: dada a indeterminabilidade de conceitos derivados dos direitos fundamentais - a exemplo da "dignidade humana" -, como conceber o Direito como uma “"ordem' fechada, invariável e coerente de regras de conduta e organização" ${ }^{219}$ ?

Por essa razão que, para propor essa discussão, entende-se ser imprescindível tentar identificar a racionalidade presente nas ações dos principais sujeitos da relação de trabalho subordinado: empregado e empregador. Enfim, se o trabalho é ação humana, há de se investigar os discursos que o permeiam. Com base nisso, é possível propor uma discussão acerca de como o sistema juslaboral brasileiro estabelece os mecanismos de contenção dos danos e violações a direitos decorrentes do exercício do poder e busca a afirmação da dignidade nas relações de trabalho subordinado.

\footnotetext{
${ }^{217}$ Terminologicamente, por direitos fundamentais entendem-se os direitos humanos consagrados pela Constituição de um Estado.

${ }^{218}$ TEUBNER, Gunther. Altera pars auditur: law in collision of discourses, cit., p. 170.

${ }^{219}$ CAMPILONGO, Celso Fernandes. op. cit., p. 44.
} 


\title{
CAPÍTULO II. EMPREGADOR E EMPREGADO: A SOCIEDADE COMPLEXA E OS VALORES CONFLITANTES
}

\author{
1. Empregador
}

\subsection{Capitalismo clássico: a crença na natureza do homo oeconomicus}

A sociedade capitalista ancorou-se em seus alicerces teóricos e realizou seus propósitos práticos. Um dos primados da economia liberal capitalista trata-se do princípio da utilidade. Influenciados pela evolução do método empírico, decantado pelos cientistas no século XVIII, os pensadores liberais, dentre eles, David Hume, Jeremy Bentham e Adam Smith, sustentavam que as relações econômicas, a exemplo de uma grande organização natural $^{220}$, seriam regidas por leis ou normas elementares da natureza física.

E qual seria a regra fundamental que direciona as ações humanas? Na óptica liberal capitalista, "os princípios da natureza humana sobre os quais deveria fundar-se toda a reflexão ética são, primeiramente, as paixões e os sentimentos, e apenas secundariamente a razão".221

Dessa forma, defende-se a menor intervenção possível de qualquer organização artificialmente concebida, como a do Estado. De qualquer forma, os teóricos liberais não afastam a importância do Estado, mas lhe conferem a função de garantir a segurança das relações.

O bem-estar público ou a felicidade ${ }^{222}$ são alcançados por meio da livre ação dos indivíduos na busca do interesse pessoal, ou seja, na realização "das paixões e dos

\footnotetext{
${ }^{220}$ Fábio Konder Comparato apresenta noções sobre a obra de Bernard Mandeville, o qual equiparou a sociedade ao organismo humano. V. COMPARATO, Fábio Konder. Ética: direito, moral e religião no mundo moderno, cit., p. 274-277.

${ }^{221}$ Id. Ibid., p. 278.

222،Por utilidade compreende-se a propriedade em qualquer objeto, a qual tende à produção de benefícios, vantagens, prazer, bens e felicidade (tudo isso geralmente são a mesma coisa) ou (o que também vem a ser a mesma coisa) prevenir o acontecimento de dano, dor, mal ou infelicidade à parte cujo interesse é considerado; se essa parte for a comunidade em geral, então trata-se da felicidade da comunidade; se for de um indivíduo particular, então é a felicidade desse indivíduo”. (MILL, John Stuart; BENTHAM, Jeremy. Utilitarism and other essays. London: Penguin Books, 2004. p. 66).
} 
sentimentos”. E a conclusão disso é que o interesse motiva o agir humano; melhor dizendo, as ações são instrumentos para a realização de um interesse e, por isso, tornam-se úteis.

Ações governamentais, como a legislativa, são convenientes, quando entendidas como úteis ao interesse geral ou da comunidade. Jeremy Bentham, então, indaga: qual seria o interesse da comunidade? Sua resposta é objetiva: a soma dos interesses dos vários membros que a compõem e, por essa razão, é infrutífero falar do interesse da comunidade sem compreender qual é o interesse do indivíduo ${ }^{223}$. Para os utilitaristas, o interesse naturalmente aspirado seria a realização da felicidade.

No primeiro parágrafo de "Teoria dos Sentimentos Morais", Adam Smith sustenta sua confiança na natureza humana, como suficiente o bastante para orientar as ações, sem a necessidade de comandos externos: "Por mais egoísta que se suponha o homem, evidentemente há alguns princípios em sua natureza que o fazem interessar-se pela sorte de outros, e considerar a felicidade deles necessária para si mesmo, embora nada extraia disso senão o prazer de assistir a ela",224. O bem comum estaria assegurado pela ação do indivíduo quando este age para seu próprio bem. A felicidade proposta pelos utilitaristas está marcada pelo egoísmo. A conquista do bem individual representaria, como condição necessária, a obtenção do bem comum. Essa seria a natureza das ações humanas.

Justifica-se a inicial ausência de normas disciplinadoras das relações econômicas, a fim de restaurar ou proteger contra desvios ou excessos de poder político. Retoma-se a lição de Max Weber, já enunciada, para quem o formalismo do Estado moderno suporta o capitalismo e suas premissas.

No que tange o modelo de trabalho no sistema capitalista, Max Weber esclarece o contraste entre as necessidades do homem e a lógica do capital, ao explicar que o aumento no valor da tarefa não induz ao aumento de produção; ao contrário, o homem trabalhará o suficiente para ganhar o que lhe é necessário para viver. Ou seja, se o valor do acre ceifado aumentar, o trabalhador não ceifará a mesma quantidade de acres, mas apenas a suficiente para garantir a remuneração com que está habituado a viver. Com esse raciocínio, Weber pretende explicar o que seria o tradicionalismo, obstáculo a ser vencido pela nova ordem econômica. Para Weber, por força da tradição,

\footnotetext{
${ }^{223}$ MILL, John Stuart; BENTHAM, Jeremy. op. cit., p. 66.

${ }^{224}$ SMITH, Adam. Teoria dos sentimentos morais. Trad. Lya Luft. São Paulo: Martins Fontes, 2002. p. 5.
} 
o homem não deseja 'naturalmente' ganhar mais e mais dinheiro, mas viver simplesmente como foi acostumado a viver e ganhar o necessário para isso. Onde quer que o capitalismo moderno tenha começado sua ação de aumentar a produtividade do trabalho humano aumentando sua intensidade, tem encontrado a teimosíssima resistência desse traço orientador do trabalho pré-capitalista. E ainda hoje a encontra, por mais atrasadas que sejam as forças de trabalho (do ponto de vista capitalista) com que tenha que lidar ${ }^{225}$.

Há de se estabelecer, assim, um novo modelo de homem e a crença na inclinação natural do indivíduo racional para a maximização do seu bem-estar com o menor dispêndio de energia possível. Surge o homo oeconomicus. Ele é descrito como o modelo geral de indivíduo, que serve de base para a economia e também para análises em outras ciências, e cujo comportamento se traduz na ação humana como escolha racional entre alternativas possíveis ${ }^{226}$. Esse discurso consegue se impor ao cenário de poder tradicional presente nas relações sociais pré-capitalistas.

Dado esse modelo de indivíduo, o sistema jurídico deve organizar um quadro de liberdade e igualdade para que os indivíduos possam agir de maneira natural. Decorre disso a imprescindibilidade de garantir direitos individuais para a persecução dos interesses almejados, restringindo, por conseguinte, eventuais ameaças à integridade do sistema capitalista.

O trunfo da ética do capitalismo repousa, portanto, na proposta de universalização da racionalidade. O trabalho, nesse contexto, "deve ser executado como se fosse um fim absoluto em si mesmo, como uma vocação"227. E como tal atitude "não é produto da natureza [...] só pode ser produzida por um longo e árduo processo educativo"228.

No texto de Weber, "trabalho como vocação" reproduz algo que não está na natureza humana, que rompe com o tradicionalismo. Trata-se de uma vocação, não de ordem essencialmente religiosa, mas devotada a fazer dinheiro. A racionalidade, na obra de Weber, invoca fatores religiosos como propulsores da sistemática capitalista. $\mathrm{O}$ valor do trabalho é determinado pelo modo econômico de produção. Estruturar, pois, o modelo

\footnotetext{
${ }^{225}$ WEBER, Max. A ética protestante e o espírito do capitalismo. Trad. Pietro Nassetti. São Paulo: Martin Claret, 2007. p. 55-56.

${ }^{226}$ KIRCHGÄSSNER, Gebhard. Homo oeconomicus: the economic model of behaviour and its applications in economics and other social sciences. New York: Springer, 2008. p. 11.

${ }^{227}$ WEBER, Max. A ética protestante e o espírito do capitalismo, cit., p. 57.

${ }^{228}$ Id., loc. cit.
} 
torna-se uma exigência para a definição dos seus componentes e da sua função dentro do sistema, isto é, é imprescindível estabelecer o modelo organização.

As estruturas do sistema capitalista adequaram-se a um modelo de organização que pôde lhe conferir segurança e reduziu a ameaça de ruptura do status quo por meio da manifestação de alguma forma de exercício de poder na sociedade, contrário aos seus interesses. Surge, nesse contexto, o modelo de Estado moderno ou Estado de Direito. Max Weber acentua:

\begin{abstract}
o Estado moderno é um agrupamento de dominação que apresenta caráter institucional e que procurou - com êxito - monopolizar, nos limites de um território, a violência física legitimada como instrumento de domínio e que, tendo esse objetivo, reunião nas mãos dos dirigentes os meios materiais de gestão. ${ }^{229}$
\end{abstract}

A burocracia e o arcabouço normativo que decorrem da estrutura estatal sustentam a ordem capitalista. E Weber assinala a importância incontestável das estruturas racionais das leis e da administração, pois o capitalismo moderno exige muito mais que meios técnicos de produção, "mas também um sistema legal calculável e de uma administração baseada em termos de regras formais" 230 .

$\mathrm{O}$ modo de produção capitalista encontrou terreno fértil para prosperar. $\mathrm{O}$ monopólio da força concentrado nas mãos do Estado garantiria os direitos individuais, a partir da sua descrição abstrata e genérica em um ordenamento jurídico.

O capitalismo adota a concepção secularizada do trabalho, ou seja, como "instrumento para atingir objetivos de valor econômico" e, para isso, "deve se adaptar as exigências do contexto" ${ }^{, 231}$. O trabalho subordinado ganha, então, os seus primeiros contornos. Desponta em um ambiente marcado pelo interesse individual, em prol de uma determinada utilidade geral traduzida na felicidade individual e comum a todos, e dentro de uma organização formalmente concebida e regulada por normas gerais e abstratas, entre as quais normas de proteção à propriedade individual. $\mathrm{O}$ trabalho, nesse cenário, tem como característica ser subordinado, porque naturalmente a sociedade, marcada pela defesa da propriedade, assim se organiza.

\footnotetext{
${ }^{229}$ WEBER, Max. A ética protestante e o espírito do capitalismo, cit., p. 66.

${ }^{230}$ Id. Ibid., p. 31.

${ }^{231}$ LANER, Aline dos Santos. Psicologia e trabalho: da apropriação do tempo à busca da felicidade. Ijuí: Ed. Unijuí, 2005. p. 78.
} 
Adam Smith afirma que:

Onde quer que haja uma grande propriedade, há uma grande desigualdade. Para cada homem rico, deve existir quinhentos pobres, e a opulência de uns pouco supõe a indigência de muitos. (...) A aquisição de propriedades extensas e valiosas, portanto, necessariamente demanda o estabelecimento do governo civil. (...) O governo civil supõe uma certa subordinação. $^{232}$

Ou seja, o poder político organizado na figura do Estado acaba por sustentar a subordinação entre os indivíduos ou, precisamente, a desigualdade. Conforme Angelo Salento, para os juristas do século XIX,

a gênese do Direito do Trabalho repousa na busca de legitimação para a relação de poder entre empregador e trabalhador subordinado em um ordenamento fundado sobre a subjetividade das pessoas formalmente livres e iguais e sobre a negação dos vínculos de 'status', no qual o único 'medium' da relação social era o ato de vontade ${ }^{233}$.

Preleciona Fábio Konder Comparato: “Tudo se reduz, portanto, à propriedade de bens. Até mesmo a autoridade política foi instituída não para garantir a segurança em todos os setores, como pretendeu Hobbes, mas unicamente para assegurar o livre gozo da propriedade". 234

\subsection{O trabalho como valor na sociedade capitalista: o valor de mercado}

O ser humano depende de condições físicas e biológico-ambientais para sua sobrevivência. Contudo, o que se revela de extrema importância no contexto capitalista é o fato de que, como Max Weber apontou, o homem "é dominado pela geração de dinheiro, pela aquisição como propósito final da vida". A consequência dessa premissa, acrescenta Max Weber, "a aquisição econômica não mais está subordinada ao homem como um meio para a satisfação de suas necessidades materiais". 235

\footnotetext{
${ }^{232} \mathrm{SMITH}$, Adam. An inquiry into the nature and causes of the wealth of nations. Chicago: Enciclopedia Britannica, 1952. p. 309.

${ }^{233}$ SALENTO, Angelo. Postfordismo e ideologie giuridiche. Milano: Franco Angeli, 2003. p. 140.

${ }^{234}$ COMPARATO, Fábio Konder. Ética: direito, moral e religião no mundo moderno, cit., p. 285.

${ }^{235}$ WEBER, Max. A ética protestante e o espírito do capitalismo, cit., p. 51.
} 
O capitalismo sistematizou-se com base em suas regras, impôs e impõe seu referencial ético, não somente no campo econômico. Constata-se que a acumulação, como mote propalado pelo capitalismo, integra a vida social, psicológica e familiar, dentre outras searas. No âmbito do trabalho humano, a regra da acumulação impulsiona o homem à produção de bens, que não necessariamente se destinam à sua sobrevivência. Ao contrário, o capitalismo não se ocupa com a satisfação de necessidades inerentemente humanas, mas à adequação da lógica do sistema econômico.

O trabalho subordinado, executado por quem não tem propriedade, não recebe proteção, mas é livremente transacionado. Ademais, no alvorecer do capitalismo industrial, é identificado pelo sistema capitalista e pelo ordenamento jurídico, como fator de produção, isto é, como um instrumento para produzir bens, a exemplo das máquinas manufatureiras. O trabalho humano é valorado economicamente como os demais objetos organizados na dinâmica da produção.

Do ponto de vista das relações humanas, o contato entre o proprietário de bens e o detentor da força de trabalho é, inerentemente, sob a lógica do capital, uma relação entre indivíduos desiguais. Assim, justifica-se, inicialmente, a ideia de controle, que direciona as relações de trabalho ou, até mesmo extensivamente, as relações capitalistas como um todo. Destarte, exercer controle sobre o trabalho é possibilitar a imposição de limites e direcionar o espaço de liberdade do ser humano qualificado como trabalhador, no meio ambiente do trabalho.

E assim, sob a ficção de que o trabalho está dissociado do homem - pois a força de trabalho consistiria na propriedade do trabalhador, como um bem -, o capital justificou o exercício do seu poder, amparado por uma estrutura burocrática institucionalizada.

Assemelha-se à postura do Estado frente aos indivíduos a relação entre empregador e trabalhador: ambos, Estado e empregador, monopolizam o exercício da força, cada um em sua esfera de controle. Michel Foucault destaca como, nas fábricas, o homem forma uma simbiose com a máquina que opera, de sorte que é disposto no espaço tal como um objeto:

Nas fábricas que aparecem no fim do século XVIII, o princípio do quadriculamento individualizante se complica. Importa distribuir os indivíduos num espaço onde se possa isolá-los e localizá-los; mas também articular essa distribuição sobre um aparelho de produção que 
tem suas exigências próprias. É preciso ligar a distribuição dos corpos, a arrumação espacial do aparelho de produção e as diversas formas de atividade na distribuição dos "postos". 236

Ao descrever uma manufatura na comuna francesa de Jouy, Foucault ressalta, uma vez mais, a redução do homem a seu corpo singularmente considerado; com a divisão do processo de produção, divide-se também o homem, por meio do que Foucault denomina “decomposição individualizante da força de trabalho". ${ }^{237}$

Essa é uma das facetas do processo de alienação. Karl Marx logrou desenvolver a sua teoria da alienação, identificando a base que sustenta a estrutura capitalista: a valorização do “individual”. Em princípio, sustentar o discurso da liberdade e igualdade individuais, em um cenário de opressão política, soa como revolucionário. E, indubitavelmente, a Revolução Francesa impôs seu discurso contra os abusos de um sistema político já desprovido de legitimidade. O problema reaparece quando se busca legitimar novas formas de opressão a partir do mesmo discurso revolucionário "libertador". No caso, em nome da igualdade e da liberdade de um indivíduo abstrato, impôs-se todo um arcabouço referencial que alimenta as relações na sociedade, incluindo as relações de produção. Em sua análise sobre a teoria da alienação em Marx, István Mészáros constata que, para o sistema capitalista, a essência humana confunde-se com a individualidade. A consequência dessa premissa é que a mera individualidade apenas reclama por meios de subsistência e prescinde de formas de auto-realização humanas, ou seja, sociais. Com isso, justifica-se a atividade produtiva em seu modelo de isolamento, conforme descrito acima por Foucault. $^{238}$

É dessa forma que a estrutura do sistema econômico compreende o trabalho:

O desenvolvimento da maquinaria e a divisão do trabalho levam o trabalho dos proletários a perder todo o caráter independente e com isso qualquer atrativo para o operário. Esse se torna um simples acessório da máquina, do qual só se requer a operação mais simples, mais monótona, mais fácil de aprender. Em decorrência, as despesas causadas pelo operário reduzem-se quase exclusivamente aos meios de subsistência de que necessita para sua manutenção e para a reprodução de sua espécie (Race). Mas o preço de uma mercadoria e, portanto, o do trabalho, é igual

\footnotetext{
${ }^{236}$ FOUCAULT, Michel. Vigiar e punir: história da violência nas prisões. Trad. Raquel Ramalhete. 22 . ed. Petrópolis: Vozes, 2000. p. 124.

${ }^{237}$ Id. Ibid., p. 125.

${ }^{238}$ MÉSZÁROS, István. A teoria da alienação em Marx. Trad. Isa Tavares. São Paulo: Boitempo, 2006. p. 80 .
} 
ao seu custo de produção. Logo, à medida que aumenta o tédio (die Widerwärtigkeit) do trabalho, diminui o salário. Mais ainda: à medida que crescem a maquinaria e a divisão do trabalho, cresce também a massa de trabalho, seja através do aumento das horas de trabalho, seja através do aumento do trabalho exigido num certo tempo, seja através da aceleração da velocidade das máquinas etc. ${ }^{239}$

É certo que as formas de produção sofreram substanciais mudanças, ainda em meados do século XX, com a introdução de novas formas de gerenciamento, a exemplo do toyotismo. ${ }^{240}$ Mas Mészáros enfatiza o caráter mais abrangente da influência que a estrutura capitalista imprime na sociedade: "O capitalismo não se caracteriza simplesmente pela alienação e reificação, mas também pela maximização da tendência à alienação, a tal ponto que é a existência mesma da humanidade que está agora em jogo”. ${ }^{241}$

Os efeitos da alienação persistem na sociedade, mesmo que assumam nova roupagem. Não é demais apresentar uma citação de Zygmunt Bauman, que reproduz um quadro de reificação no contexto atual:

Condições econômicas e sociais precárias treinam homens e mulheres (ou os fazem aprender pelo caminho mais difícil) a perceber o mundo como um contêiner cheio de objetos descartáveis, objetos para uma só utilização; o mundo inteiro - inclusive outros seres humanos. (...) Num mundo em que o futuro é, na melhor das hipóteses, sombrio e nebuloso, porém mais provavelmente cheio de riscos e perigos, colocar-se objetivos distantes, abandonar o interesse privado para aumentar o poder do grupo e sacrificar o presente em nome de uma felicidade futura não parecem uma proposição atraente, ou mesmo razoável. ${ }^{242}$

Desse cenário traçado por Bauman extraem-se, uma vez mais, as bases do sistema capitalista: o homem como objeto e a preferência pelo individualismo. Porém, o indivíduo age premido pela influência da dominação da ordem racionalmente organizada (ou, na teoria weberiana, da estrutura da organização burocrática, como o aparato administrativo

\footnotetext{
${ }^{239}$ ENGELS, Friedrich; MARX, Karl. Manifesto do Partido Comunista. Petrópolis: Vozes, 1988. p. 72-73.

${ }^{240} \mathrm{O}$ toyotismo "utiliza-se de novas técnicas de gestão da força de trabalho, do trabalho em equipe, das 'células de produção', dos 'times de trabalho', dos grupos 'semi-autônomos', além de requerer, ao menos no plano discursivo, o 'envolvimento participativo' dos trabalhadores, em verdade uma participação manipuladora e que preserva, na essência, as condições do trabalho alienado e estranhado. O 'trabalho polivalente', 'multifuncional', 'qualificado', combinado com uma estrutura mais horizontalizada e integrada entre diversas empresas, inclusive nas empresas terceirizadas, tem como finalidade a redução do tempo de trabalho." (ANTUNES, Ricardo. Os sentidos do trabalho: ensaio sobre a afirmação e a negação do trabalho. 6. ed. São Paulo: Boitempo Editorial, 2002. p. 52.)

${ }^{241}$ MÉSZÁROS, István. op. cit., p. 228.

${ }^{242}$ BAUMAN, Zygmunt. Modernidade líquida. Trad. Plínio Dentzien. Rio de Janeiro: Jorge Zahar, 2001. p. 186-187.
} 
estatal, o capitalismo, a ciência ), o que refuta o próprio pressuposto para a existência do indivíduo: liberdade com autoconsciência. A insistência na noção de indivíduo em uma sociedade marcada por discursos de dominação trata-se de um paradoxo imposto pela modernidade.

Ainda cabe pontuar outro aspecto: a opção por objetivos imediatos. Pensar soluções rápidas e imediatas está na estrutura operacional do capitalismo e essa postura pode conduzir a escolhas que se contrapõem a uma teoria jurídica de proteção ao ser humano. A adequação da lógica econômica ao ordenamento jurídico resulta na não efetividade de valores essenciais à existência humana, como a saúde. Exemplo disso é a opção do legislador pelo adicional de insalubridade. Diante da inevitabilidade de expor o ser humano a determinadas condições que comprometem sua saúde, optou-se pelo ressarcimento pecuniário. Ou seja, utilizou-se a lógica do capital e "mercantilizou-se" o comprometimento à saúde.

Em momento oportuno, desenvolver-se-á um exemplo de como a exploração do trabalhador e o comprometimento de sua integridade passaram a ser aceitos, aparentemente sem qualquer contestação, a partir da monetarização do risco à saúde; trata-se do adicional de insalubridade. $\mathrm{O}$ adicional de insalubridade traduz a utilização do referencial do detentor do poder (capitalista), reduzindo a possibilidade de ação do outro (trabalhador).

\subsubsection{O direito à redução de riscos no meio ambiente do trabalho no ordenamento jurídico brasileiro: o alcance da dignidade do trabalhador}

O sistema jurídico brasileiro estrutura-se sobre a natural indissolubilidade do trabalho e o homem, de sorte que disciplinar a relação de emprego é regular a atuação do capital não somente sobre a atividade laboral, mas sobre o próprio homem.

A Constituição Federal de 1988 (CF/88), em seu artigo $7^{\circ}$, inciso XXII, prevê como direito fundamental a "redução dos riscos inerentes ao trabalho, por meio de normas de saúde, higiene e segurança”. Interessante notar que, embora repercuta diretamente nos contratos de trabalho subordinado e, portanto, de natureza individual, o conteúdo da norma constitucional foca o aspecto coletivo: o meio ambiente do trabalho. A redução de riscos inerentes à determinada atividade laboral abrange não somente um determinado indivíduo, mas todos aqueles que dispuseram, dispõem e venham a dispor de sua força de trabalho 
naquele espaço físico da empresa. Ou seja, os sujeitos de direito são determináveis, mas não necessariamente determinados, o que caracteriza os chamados direitos fundamentais da terceira geração ou dimensão.

Nesse contexto, há um aspecto objetivo que orienta o legislador: a exposição de um ser humano a um ambiente de trabalho que apresenta riscos de ordem física, química e/ou biológica à sua vida ou saúde. Diante disso, a análise do legislador para definir riscos e suas consequências parte de dados técnico-científicos (identificação das propriedades e quantidade de agentes físicos, químicos e/ou biológicos danosos à saúde).

No exercício da competência atribuída pelo artigo 22, inciso I, da Constituição Federal de 1988, a União legisla privativamente sobre o direito do trabalho. Recepcionado pela ordem constitucional, o artigo 155 da CLT (Consolidação das Leis do Trabalho) incumbe ao órgão de âmbito nacional competente em matéria de segurança e medicina do trabalho, qual seja o Ministério do Trabalho e Emprego (MTE), estabelecer normas de aplicação sobre essa matéria. Coube à Portaria n. 3214/1978 regulamentar, pois, a norma infraconstitucional, por meio da aprovação das denominadas Normas Regulamentadoras (NRs). Atualmente encontram-se vigentes 33 (trinta e três) NRs.

A aparente inflação de NRs, somadas às normas da Consolidação das Leis do Trabalho (CLT) (artigos 154 a 351) traduzem a complexidade e pluralidade de situações adversas a que podem estar sujeitos os trabalhadores no ambiente de trabalho. Com vistas a adequar o ambiente do trabalho antes mesmo de expor o ser humano a riscos de morte ou comprometimento da saúde, o artigo 160 da CLT prevê a chamada inspeção prévia, que consiste na aprovação das respectivas instalações pela autoridade ministerial regional competente responsável pela segurança e medicina do trabalho. Observa-se que o legislador, no $\S 2^{\circ}$ do mesmo artigo, faculta às empresas submeter o projeto de construção e das respectivas instalações ao órgão regional do Ministério do Trabalho e Emprego. O propósito do legislador, nesse caso, é evitar que, após a edificação e instalação da empresa, se constatem irregularidades decorrentes da execução de um projeto em desacordo com as NRs, que possam vir a inviabilizar por completo a realização das atividades econômicas no estabelecimento, por conta dos riscos à vida ou à saúde do trabalhador.

O artigo 157 da CLT relaciona, em linhas gerais, os deveres das empresas: 
Art. 157 - Cabe às empresas:

I - cumprir e fazer cumprir as normas de segurança e medicina do trabalho;

II - instruir os empregados, através de ordens de serviço, quanto às precauções a tomar no sentido de evitar acidentes do trabalho ou doenças ocupacionais;

III - adotar as medidas que lhes sejam determinadas pelo órgão regional competente;

IV - facilitar o exercício da fiscalização pela autoridade competente. ${ }^{243}$

Com o fito de garantir a eficácia das normas, o artigo 156 confere competência às Superintendências e Gerências Regionais do Trabalho e Emprego (GRTEs) para: a) promover a fiscalização do cumprimento das normas de segurança e medicina do trabalho; b) adotar as medidas que se tornem exigíveis, determinando reparos e/ou obras necessárias, em qualquer local de trabalho; c) impor as penalidades cabíveis por descumprimento das normas.

Organizar, manter e executar a inspeção do trabalho é competência da União, conforme previsto constitucionalmente no artigo 21, inciso XXIV. O exercício da inspeção ou fiscalização do trabalho constitui uma das manifestações do Poder de Polícia Administrativa, o qual, dentre outras características, visa à prevenção de danos à coletividade por desrespeito a normas destinadas à proteção do bem-estar geral. Voltado à prevenção, o Poder de Polícia Administrativa, em princípio, busca o ajustamento de condutas às normas jurídicas e, para tanto, dispõe de instrumentos coercitivos no caso de recalcitrância do administrado. Em regra, as penalidades, a exemplo das referidas no artigo 156 da CLT, constituem medidas coercitivas indiretas, ou seja, o Estado, no exercício do Poder de Polícia Administrativa, não cerceia o exercício do direito do administrado, mas impõe uma sanção indireta (por exemplo, multa), a fim de desestimular a conduta contrária à legislação ${ }^{244}$. De maneira diferente, o Poder de Polícia Judiciária destina-se à repressão, com cerceamento de direitos dos administrados; como exemplo, a decretação de prisão temporária (restrição total do direito à liberdade), prevista na Lei n. 7960/1989. E admitese a repressão com fundamento nos postulados de constituição da sociedade civil: a

\footnotetext{
${ }^{243}$ CONSOLIDAÇÃO das Leis do Trabalho, Código de Processo Civil, Legislação Trabalhista e Processual Trabalhista, Legislação Previdenciária, Constituição Federal. Obra coletiva de autoria da Revista dos Tribunais. 10. ed. rev. ampl. e atual. São Paulo: Ed. Revista dos Tribunais, 2009. p. 246.

${ }^{244} \mathrm{O}$ exercício e os impactos do poder de polícia administrativa pela Fiscalização Federal do Trabalho são subtemas a serem desenvolvidos no Capítulo III.
} 
garantia da segurança, do respeito à vida e à propriedade. Afinal, o exercício da liberdade de maneira ilimitada, portanto sem restrições, põe em risco a liberdade em si mesma (liberdade como propriedade).

Por essa razão, embora a regra geral seja a aplicação de medidas coercitivas indiretas, quando um laudo técnico de serviço competente demonstrar que há grave e iminente risco para o trabalhador, o legislador autoriza à fiscalização do trabalho, no exercício do Poder de Polícia Administrativa, impor medidas coercitivas diretas: o embargo de obra e a interdição de estabelecimento, setor de serviço, máquinas ou equipamentos (artigo 161 da CLT). Nos termos do artigo 161, $\S 6^{\circ}$, da CLT, "durante a paralisação dos serviços, em decorrência da interdição ou embargo, os empregados receberão os salários como se estivessem em efetivo serviço". Um exemplo pode ser extraído da NR-15, que trata das atividades e operações insalubres. O Anexo 13 da referida Norma Regulamentadora proíbe a exposição ou contato do trabalhador, por qualquer via, a processos e a substâncias cancerígenas discriminadas: 4-amino difenil (p-xenilamina); Produção de Benzidina; Beta-naftilamina; e 4-nitrodifenil. A autoridade ministerial competente determina, nessas hipóteses, que "sempre que os processos ou operações não forem hermetizados, será considerada como situação de risco grave e iminente para o trabalhador", o que enseja a interdição do estabelecimento, isto é, o cerceamento do direito à exploração da atividade econômica e da propriedade. Reforça-se que as hipóteses de intervenção estatal repressiva são justificadas pelo bem jurídico em risco grave e iminente: a vida ou a saúde do trabalhador.

Assim, o ordenamento jurídico reconhece a existência de determinadas atividades cujas condições ou métodos expõem o trabalhador a agentes nocivos à saúde, acima dos limites de tolerância fixados em razão da natureza e da intensidade do agente e do tempo de exposição aos seus efeitos. Trata-se das atividades insalubres. Como foi visto acima, há atividades insalubres em que não se admite a exposição do trabalhador em nenhuma circunstância ao contato com o agente nocivo (exemplo das substâncias cancerígenas). Entretanto, existem outras atividades em que se admite a exposição do trabalhador a agentes nocivos, dentro dos limites de tolerância previstos nas normas técnicas (NRs). São atividades que, em regra, não geram grave e iminente risco à vida ou à saúde do ser humano. De acordo com o item 15.1.5 da já mencionada NR-15, o "limite de tolerância" é a concentração ou intensidade máxima ou mínima, relacionada com o tempo de exposição ao agente, que não causará dano à saúde do trabalhador, durante a sua vida laboral. A 
adequação aos limites de tolerância é possível por meio de medidas de proteção ao ambiente do trabalho (por exemplo, redução de ruídos de máquinas ou equipamentos com a vedação dos mesmos em compartimentos anti-ruídos, quando possível) e/ou com a utilização de equipamentos de proteção individual ao trabalhador (EPI), por exemplo, como protetores auriculares.

A exposição a condições de trabalho insalubres assegura ao trabalhador a percepção do adicional de insalubridade, cujo percentual, incidente sobre o salário mínimo da região, será calculado de acordo com o grau de risco: $40 \%$ para grau máximo; 20\% para grau médio; $10 \%$ para grau mínimo. ${ }^{245}$ Exemplo do Anexo 13 da NR-15: processo de produção de trióxido de arsênico constitui atividade insalubre de grau máximo, enquanto processo de fabricação de tafetá sire é considerada atividade insalubre de grau mínimo.

Porém, se, por meio de uso efetivo dos equipamentos de proteção individual, aprovados pelo órgão competente do Poder Executivo, houver eliminação da insalubridade, a Súmula 80 do Tribunal Superior do Trabalho (TST) pacificou entendimento no sentido de excluir do trabalhador o direito à percepção do respectivo adicional. A exclusão do adicional ou a reclassificação do grau de risco de insalubridade depende, pois, da adoção de medidas que conduzam à eliminação ou à diminuição da nocividade, de sorte que o mesmo TST, na Súmula 289, não afasta a obrigatoriedade do pagamento do adicional pelo simples fornecimento do aparelho de proteção ao empregado; há de se garantir o efetivo uso do equipamento de proteção individual ou coletivo.

Em face disso, qual é o papel do empregador? O empregador deverá fiscalizar o efetivo uso do equipamento pelo empregado. Entretanto, uma vez recebido o equipamento de proteção, o legislador atribui também ao empregado a obrigação de colaborar com a empresa no cumprimento das normas de segurança e medicina do trabalho, conforme previsto no artigo 158 da CLT, in verbis:

Art. 158 - Cabe aos empregados:

I - observar as normas de segurança e medicina do trabalho, inclusive as instruções de que trata o item II do artigo anterior;

II - colaborar com a empresa na aplicação dos dispositivos deste Capítulo.

\footnotetext{
${ }^{245} \mathrm{~A}$ discussão sobre as repercussões jurídicas das normas infraconstitucionais sobre adicional de insalubridade e a Súmula Vinculante n. 4 do STF serão abordadas no item destinado à análise econômica. O objetivo nesse momento é descrever o conteúdo da legislação sobre a matéria.
} 
Parágrafo único - Constitui ato faltoso do empregado a recusa injustificada:

a) à observância das instruções expedidas pelo empregador na forma do item II do artigo anterior;

b) ao uso dos equipamentos de proteção individual fornecidos pela empresa. ${ }^{246}$

Extrai-se do dispositivo legal acima que o descumprimento injustificado das normas de segurança e medicina pelo trabalhador configura ato faltoso, que autoriza o empregador a rescindir o contrato de trabalho por justa causa, em consonância com os termos do artigo 482, alínea $h$, da CLT (ato de indisciplina).

A Consolidação das Leis do Trabalho, em seu artigo 193, dispõe sobre outro adicional devido em razão da exposição do trabalhador a atividades ou operações perigosas:

Art. 193 - São consideradas atividades ou operações perigosas, na forma da regulamentação aprovada pelo Ministério do Trabalho, aquelas que, por sua natureza ou métodos de trabalho, impliquem o contato permanente com inflamáveis ou explosivos em condições de risco acentuado.

$\S 1^{\circ}$ - O trabalho em condições de periculosidade assegura ao empregado um adicional de $30 \%$ (trinta por cento) sobre o salário sem os acréscimos resultantes de gratificações, prêmios ou participações nos lucros da empresa.

$\S 2^{\circ}$ - O empregado poderá optar pelo adicional de insalubridade que porventura lhe seja devido. ${ }^{247}$

O artigo 194 prevê a supressão do pagamento do adicional de insalubridade ou de periculosidade, em caso de eliminação de risco:

Art. 194 - O direito do empregado ao adicional de insalubridade ou de periculosidade cessará com a eliminação do risco à sua saúde ou integridade física, nos termos desta Seção e das normas expedidas pelo Ministério do Trabalho. ${ }^{248}$

Na hipótese de o descumprimento das disposições de proteção à segurança e medicina do trabalho culminar em acidente de trabalho, comprovado o dolo ou a culpa, o

\footnotetext{
${ }^{246}$ CONSOLIDAÇÃO das Leis do Trabalho, Código de Processo Civil, Legislação Trabalhista e Processual Trabalhista, Legislação Previdenciária, Constituição Federal, cit., p. 246.

${ }^{247}$ Id. Ibid., p. 252.

${ }^{248}$ Id., loc. cit.
} 
empregador estará obrigado a pagar indenização (artigo $7^{\circ}$, inciso XXVIII, da Constituição Federal). Sendo assim, a regra geral é a responsabilização subjetiva do empregador.

Não obstante a proteção legal, em publicação de 2004, o Ministério do Trabalho e Emprego traçou o perfil de morte e adoecimento relacionado ao trabalho, destacando esquematicamente o perfil de morbimortalidade dos trabalhadores no Brasil pela coexistência dos seguintes fatores ${ }^{249}$ :
a) agravos que têm relação com condições de trabalho específicas, como os acidentes de trabalho típicos e as "doenças profissionais";
b) doenças que têm sua frequência, surgimento ou gravidade modificados pelo trabalho, denominadas "doenças relacionados ao trabalho" e;
c) doenças comuns ao conjunto da população, que não guardam relação de causa com o trabalho, mas condicionam a saúde dos trabalhadores.

Na mesma análise, o MTE constatou a existência de "escassez e inconsistência das informações sobre a real situação de saúde dos trabalhadores", que "dificultam a definição de prioridades para as políticas públicas, o planejamento e implementação das ações de saúde do trabalhador, além de privar a sociedade de instrumentos importantes para a melhoria das condições de vida e trabalho". Tomando por base apenas as informações disponíveis, ou seja, apenas as referentes aos trabalhadores segurados pelo Instituto Nacional de Seguridade Social (INSS), no período de 1999 a 2003, foram registrados 1.875.190 (um milhão, oitocentos e setenta e cinco mil e cento e noventa) acidentes de trabalho, sendo 15.293 (quinze mil, duzentos e noventa e três) com óbito e 72.020 (setenta e dois mil e vinte) trabalhadores com incapacidade permanente. De acordo com esses dados, o Ministério da Previdência Social apurou que o coeficiente médio de mortalidade do período considerado foi de 14,84 (quatorze vírgula oitenta e quatro) por 100.000 (cem mil) trabalhadores, o que, em comparação com outros países (Finlândia, com coeficiente de 2,1, no ano de 2001; França de 4,4, em 2000; Canadá de 7,2, ano-base 2002; e Espanha de 8,3, em 2003), implica que o risco de morrer por acidente de trabalho no Brasil é cerca de duas a cinco vezes maior. O mais alarmante, contudo, é que, segundo estimativa da

\footnotetext{
${ }^{249}$ BRASIL. MINISTÉRIO DO TRABALHO E EMPREGO. Política Nacional de Segurança e Saúde do Trabalhador: Proposta para Consulta Pública - versão pronta após sugestões - 29.12.2004. Brasília, 2004. p. 6. Disponível: em: <http://www.mte.gov.br/seg_sau/proposta_consultapublica.pdf>. Acesso em: 20 dez. 2008.
} 
Organização Mundial de Saúde, na América Latina, apenas $1 \%$ a $4 \%$ das doenças do trabalho são notificadas. ${ }^{250}$

Cabe, então, questionar por que as leis de proteção à saúde e segurança do trabalho $^{251}$ não estimulam condutas que revertam tais índices desastrosos.

\subsubsection{O referencial do sistema econômico e as medidas para redução de risco no ambiente de trabalho}

Algumas premissas são necessárias para compreender a dinâmica das relações de trabalho, especificamente quanto à prevenção de acidentes, a partir da racionalidade econômica. Para iniciar uma análise sob a perspectiva econômica, faz-se mister enunciar o modelo de racionalidade dos agentes nessa relação entre trabalho subordinado e a responsabilidade pela proteção à vida e à saúde do trabalhador. A partir da abordagem de Sidney A. Shapiro, a teoria econômica prevê a seguinte conduta dos agentes racionais:

a) os trabalhadores demandarão remuneração adicional, ou um "prêmio adicional", para compensá-los dos riscos à saúde e à segurança a que são expostos no ambiente de trabalho;

b) os empregadores adotarão medidas de redução de riscos até o ponto de ser menos custoso pagar aos trabalhadores o adicional sobre a remuneração do que investir na implementação de prevenção contra riscos à saúde e à segurança do trabalhador. ${ }^{252}$

Uma vez pressuposto o comportamento dos agentes econômicos, é importante definir quais regras geram as consequências aspiradas pela coletividade, ou seja, dados os

\footnotetext{
${ }^{250}$ BRASIL. MINISTÉRIO DO TRABALHO E EMPREGO. Política Nacional de Segurança e Saúde do Trabalhador: Proposta para Consulta Pública - versão pronta após sugestões - 29.12.2004, cit., p. 6-7.

251،A segurança no trabalho é definida como um conjunto de medidas diversificadas, destacando-se as de engenharia, adequadas à prevenção de acidentes de trabalho e utilizadas para reconhecimento e controle de riscos associados ao local de trabalho e ao processo produtivo (materiais, equipamentos e procedimentos corretos). A prevenção é o conjunto de todas as ações que visam evitar os erros ou a ocorrência de defeitos, englobando a própria organização do trabalho e as relações sociais na empresa, portanto a verdadeira prevenção é aquela integrada no trabalho implicando em três ações fundamentais: planejamento prévio das operações, elaboração procedimentos corretos e programa de formação profissional." (MELO, Maria Bernardete Fernandes Vieira de. Influência da cultura organizacional no sistema de gestão da segurança e saúde no trabalho em empresas construtoras. 2001. Tese (Doutorado em Engenharia de Produção) Universidade Federal de Santa Catarina, Florianópolis, 2001. p. 34-35).

${ }^{252}$ SHAPIRO, Sidney A. Occupational safety and health regulation. Encyclopedia of Law and Economics, p. 596. Disponível em: <http://encyclo.findlaw.com/5540book.pdf>. Acesso em: 10 dez. 2008.
} 
indivíduos com as características acima quais regras incentivariam a produção de resultados próximos ao padrão desejado pela sociedade. Aqui se inicia o processo de intersecção entre Direito e Economia, "não apenas para teorizar e analisar o impacto do direito sobre a economia, mas também para avaliar a própria qualidade dos instrumentos legais, de acordo com métricas econômicas definidas". ${ }^{253}$

Armando Castelar Pinheiro e Jairo Saddi destacam quais seriam as premissas fundamentais para a análise econômica do direito:

a) O ser humano sempre procura aquilo que considera ser o melhor para si, preferindo mais a menos satisfação. Formalmente, diz-se que os agentes econômicos agem de maneira racional, procurando maximizar sua utilidade.

b)No processo de maximização da sua utilidade, as pessoas reagem aos incentivos que recebem do ambiente em que vivem e trabalham, incluindo o sistema de preços.

c) As regras legais moldam os incentivos a que as pessoas estão submetidas e, portanto, influem nas suas decisões de troca, produção, consumo, investimento etc. ${ }^{254}$

A previsão de direitos sociais aos trabalhadores implica a questão da interferência do poder estatal sobre a autonomia dos particulares. Há críticas a essa intervenção. As décadas de 80 e 90 do século XX marcaram a retomada do discurso pela não-intervenção estatal na esfera econômica. Marcelo Batuíra da C. Losso Pedroso, em sua tese de doutoramento, defende a liberdade contratual e, por isso, uma revisão das funções do Direito do Trabalho. Sustenta que o intervencionismo estatal compromete o livre mercado, cerceando a liberdade individual para definir regras contratuais. ${ }^{255}$

Porém, nos modelos contratualistas já expostos no item 2 do Capítulo I, a intervenção é pressuposto do próprio modelo de Estado e contrato, construído sob um sistema capitalista. Aliás, o mercado não existe sem o Estado e a segurança das relações sócio-econômicas, indispensáveis para o desenvolvimento dos mecanismos do capital, não é possível sem as restrições jurídicas. A autonomia privada (como expressão da liberdade), assim como outros princípios caros ao sistema jurídico, não é absoluta, pois há de conciliá-

\footnotetext{
${ }^{253}$ PINHEIRO, Armando Castelar; SADDI, Jairo. Direito, economia e mercados. Rio de Janeiro: Elsevier, 2005. p. 83.

${ }^{254}$ Id. Ibid., p. 89.

${ }^{255}$ PEDROSO, Marcelo Batuíra da C. Losso. Liberdade e irrenunciabilidade no direito do trabalho: do estudo dos princípios à "Economic Analysis of Law" aplicados aos Direito do Trabalho. Porto Alegre: Sérgio Antonio Fabris Editor, 2005.
} 
la com outros princípios e valores do Estado Democrático de Direito, como autonomia pública, igualdade, solidariedade e, sobretudo, como foi apontado, a vida e a segurança das relações. ${ }^{256}$ Daniel Sarmento destaca que, em uma democracia, "estas intervenções estatais

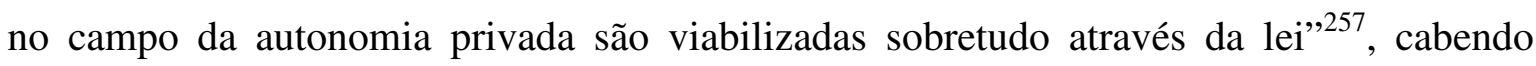
acrescentar que a lei, no Direito Moderno, é resultado de uma construção da razão humana.

Diante dessas premissas, propõe-se, pois, um problema, integrando as premissas jurídicas e econômicas: "como tornar eficazes as medidas de promoção de valores humanitários, em especial as normas de proteção de segurança do trabalhador contra o risco de acidentes", o que equivale a dizer "como incentivar eficientemente a conduta dos agentes com vistas a gerar comportamentos adequados ao padrão devido, o qual é definido pela sociedade". A questão é estimular condutas a partir da comprovação de que o comportamento contrário a regras gera consequências menos maximizadoras dos interesses dos agentes. Enfim, o que se busca são transações que maximizem a "riqueza" de uma sociedade, ou seja, conjunto dos bens e serviços tangíveis e intangíveis ${ }^{258}$, dentre eles a vida e a saúde do trabalhador.

Nesses termos, Richard A. Posner lembra que pode parecer artificial falar sobre acidente como transação, mas ele examina a transação potencial que consiste em comprar a medida de segurança que teria evitado o acidente:

Tendo em vista que uma vítima potencial não pagaria \$3 para evitar um custo esperado de acidente de $\$ 1$, seu preço ofertado será inferior ao preço solicitado do causador potencial do dano, e a transação não será maximizadora de riqueza. Porém, se esses números forem invertidos - se um custo esperado de acidente de $\$ 3$ pudesse ser evitado a um custo de $\$ 1$-, a transação seria maximizadora de riqueza. ${ }^{259}$

O exemplo proposto por Richard A. Posner pode suscitar uma indagação: se o objetivo é propor transações que maximizem "riqueza", admite-se expor em risco à vida de um ser humano se tal comportamento for menos oneroso? É aqui que se torna imprescindível esclarecer qual o padrão devido de comportamento escolhido pela sociedade, que se define, racionalmente, no processo de elaboração da Constituição do Estado. Nesses termos, a Constituição, como expressão da vontade geral, informa quais os

\footnotetext{
${ }^{256}$ SARMENTO, Daniel. Direitos fundamentais e relações privadas. Rio de Janeiro: Lumen Juris, 2004. p. 189.

${ }^{257}$ Id. Ibid., p. 190.

${ }^{258}$ POSNER, Richard A. Problemas de filosofia do direito. São Paulo: Martins Fontes, 2007. p. 477.

${ }^{259}$ Id. Ibid., p. 480.
} 
parâmetros sobre os quais serão disciplinadas as condutas para a maximização das utilidades preferidas por determinada sociedade.

Quando o ordenamento jurídico proíbe determinadas condutas, limitando a autonomia privada na contratação de trabalho subordinado - por exemplo, ao proibir o contato do trabalhador com substâncias cancerígenas, mesmo que este concorde em troca de uma vultosa compensação financeira mensal -, o propósito é manter a estabilidade social, se a sociedade escolheu que ela depende da garantia da saúde e da vida do ser humano. Há de se avaliar as consequências: imagina-se uma empresa com um quadro de 200 (duzentos) trabalhadores expostos a ruídos acima dos limites de tolerância, configurando a hipótese de grave e iminente risco, conforme a norma regulamentadora. Dada a falta de recursos para tornar altamente eficiente o mecanismo de fiscalização de trabalho, o empregador avalia que o risco de ser autuado e ter seu estabelecimento interditado é baixo e prefere manter os trabalhadores nas condições contrárias às normas de proteção. Após essa avaliação de risco, o empregador constata que os trabalhadores, contudo, estão insatisfeitos com as condições de trabalho porque obtiveram a informação sobre os riscos à sua saúde, destacadamente a possibilidade de perda de audição. O empregador, então, propõe aos trabalhadores o pagamento de um adicional de 50\% (cinquenta por cento) do salário em troca da não aquisição de equipamentos de proteção individual e/ou coletivos, cujo custo ao empregador seria maior. Diante da proposta, os trabalhadores firmam acordo com o empregador. Um acordo dessa natureza não é admissível no ordenamento jurídico brasileiro. O legislador obriga o empregador a adotar as medidas de eliminação ou neutralização dos riscos à saúde e segurança do trabalhador, sob pena de sanção administrativa e de configuração de culpa ou dolo (falta do devido cuidado). E a razão da proibição de se conferir efeitos jurídicos repousa na natureza dos bens: "saúde" e "vida" não são transacionáveis, porque sua garantia é indispensável para a estabilidade e cooperação entre os indivíduos. O aviltamento desses valores tende a produzir instabilidade e insegurança sociais.

Dessa maneira, a vedação à transação de determinados bens jurídicos não constitui uma negação do direito à liberdade (como propriedade), mas é justificada pelo objetivo a ser alcançado pelo Direito. Como destaca Robert Cooter e Thomas Ullen,

um sistema legal tenta minimizar os desajustes e as falhas de cooperação, os quais são onerosos para a sociedade. A importância da minimização de perdas por desajustes foi especialmente analisado pelo filósofo inglês do século XVII, Thomas Hobbes. Hobbes considerou que as pessoas 
raramente seriam suficientemente racionais para concordar com a divisão do excedente cooperativo, mesmo quando não houvesse rígidos impedimentos para negociar. A natural cupidez dos indivíduos os conduziria a conflitos a não ser que um terceiro, uma parte mais forte os obrigasse a entrar em acordo. ${ }^{260}$

Prossegue o autor para concluir que essas considerações sugerem o seguinte princípio de direito de propriedade (e, por conseguinte, do exercício da liberdade), o qual Robert Cooter denominou de teorema normativo de Hobbes: "Estruture o Direito de forma a minimizar o dano causado pelas falhas provocadas nos acordos entre particulares". 261

No caso do referencial do empregador, o sistema econômico define os contornos do conceito de trabalho. E a conclusão é a de que nem sempre a redução dos custos e a busca do máximo bem-estar individual culminam em bons resultados para a coletividade como um todo.

\section{Empregado}

\subsection{Empregado como "indivíduo flexível”}

O trabalho subordinado é concebido no contexto do capitalismo clássico, desenvolvido com o modo de produção industrial, a partir do século XVIII. É nesse contexto que se destaca o indivíduo como entidade fundamental, caracterizado pela racionalidade, auto-interesse e maximização de seus interesses ${ }^{262}$, conferindo a ele, portanto, a total capacidade para a realização de seus objetivos. Há, pois, um momento de transição em que o "homem” é reconhecido como "indivíduo".

\footnotetext{
${ }^{260}$ COOTER, Robert; ULLEN, Thomas. Law and economics. $3^{\text {rd }}$. ed. Massachusetts: Addison Wesley Longman, 2000. p. 94.

${ }^{261}$ Id., loc. cit.

${ }^{262}$ Ao tratar do paradigma da modernidade, Chiappin e Leister destacam: "A tese ontológica fundamental afirma ter existência real apenas o indivíduo. Essa tese tem como versão mais moderna o individualismo ontológico e metodológico. [...] A ligação entre a ação coletiva e a ação individual é estabelecida pela vertente reducionista, uma vez que o programa tem como tese central a tese ontológica do indivíduo como racional e auto-interessado, que, portanto, exige a redução da ação coletiva à ação individual.” (CHIAPPIN, J. R. N.; LEISTER, C. op. cit., p. 5-6).
} 
Sob a óptica econômica, a sociedade é constituída por indivíduos racionais, livres e maximizadores do seu bem-estar. O modelo do homo oeconomicus permite estudar e aproveitar o ser humano com base em um enfoque objetivo. O homem, visto dessa forma, é compreendido a partir do referencial físico - corpo -, como ser biológico e não mais a partir de reflexões filosóficas ${ }^{263}$.

É possível depreender da perspectiva do trabalho sob a óptica do empregador que a concepção de indivíduo aflora intimamente relacionada à noção de trabalho subordinado.

Conclui-se que o Iluminismo valorizou a razão para conceber o homem livre, igual e solidário, e conferiu os fundamentos do sistema econômico em desenvolvimento: o capitalismo. Na medida em que o sistema capitalista se expandia e se afirmava como sistema econômico e produtivo, salienta Pedro Bendassolli que ele contribuiu para o nascimento do indivíduo ${ }^{264}$. A divisão do trabalho e a organização técnico-científica da produção transformam o "homem" em "indivíduo", qualificando-o como peça de uma grande engrenagem. Assim, o trabalhador é individualizado pela função e importância na cadeia produtiva. Também é a posição do trabalhador e sua participação na produção de bens que permitem identificar a qual classe ele pertence na sociedade. A noção de classe substitui, do ponto de vista de organização social, a de status. Não há mais rigidez da sociedade feudal, mas há uma classificação social agora derivada do papel exercido pelo homem no sistema capitalista.

Esse atrelamento entre individualidade-trabalho subordinado ressalta a proeminência do viés econômico para a construção da análise sobre o valor do ser humano objetivamente considerado. Com o desenvolvimento das ciências humanas, nasce uma visão psicológica do homem, nos finais do século XIX e, em princípios do século $\mathrm{XX}^{265}$. A partir da análise psicológica, extrai-se a centralidade do trabalho no processo de construção psicológica da identidade, "quer dizer, do sentido que um indivíduo dá de si mesmo"266.

Nesse quadro, a preocupação com a temática trabalhista, portanto, aflora como necessidade natural para a manutenção do próprio sistema capitalista. Inicialmente, fica mais evidente o porquê não houve debate sobre as necessidades humanas no seio das

\footnotetext{
${ }^{263}$ FISCHER, Gustave-Nicolas. Os conceitos fundamentais da psicologia social. Lisboa: Instituto Piaget, 2002. p. 17.

${ }^{264}$ BENDASSOLLI, Pedro Fernando. op. cit., p. 20.

${ }^{265}$ FISCHER, Gustave-Nicolas. Os conceitos fundamentais da psicologia social, cit., p. 17.

${ }^{266}$ BENDASSOLLI, Pedro Fernando. op. cit., p. 16.
} 
atividades produtivas, porque o homem deixa de sê-lo ao concluir o contrato de trabalho, ocasião em que exerceu a sua liberdade, em condições de igualdade. Ao assumir, por força do contrato, a condição de indivíduo na organização produtiva, o trabalhador deveria empreender seus esforços para a maximização dos interesses econômicos, os quais, conforme celebrado contratualmente, resultaria na ampliação do capital (interesse do empregador) e na garantia de pagamento da contraprestação e do próprio trabalho (interesse do trabalhador).

À medida que as relações de trabalho subordinado se desenvolvem e se observam os efeitos da primazia do viés econômico, o Direito assume o papel de institucionalizar os valores e princípios constitucionais no contexto das relações sociais. O Direito não pode se ocupar com a reconstituição da unidade social perdida, identificando valores, princípios e normas como válidos para o sistema jurídico, mas deve minimizar as violações, rupturas e danos provocados na colisão entre discursos. A função do sistema jurídico é evitar que, na colisão entre discursos de racionalidades diferentes, se estabeleça na sociedade uma relação de dominação, incompatível com a segurança do sistema social, econômico e político. Exemplo da desestruturação do sistema social, imposta pela dinâmica da dominação, os movimentos sociais desencadeados coletivamente pelos trabalhadores inconformados com a depauperização da condição humana, nos séculos XIX e XX, traduziram-se em irritações profundas, hábeis a ensejar a ruptura do próprio sistema capitalista, proposta pelo movimento marxista.

Por isso, quando o indivíduo - como ente racional e maximizador de interesses - é substituído pelo trabalhador hipossuficiente e em situação flagrantemente desigual em face do empregador, o que o Direito faz é reconhecer a relação de dominação fruto de um aumento da complexidade social. Não há espaço para o "homem" dos Iluministas, nem para o "indivíduo" dos capitalistas. Surge o ser-que-trabalha, como racionalidade intrínseca ao sistema capitalista e que, por essa razão, carece de proteção.

O Direito do Trabalho parte do princípio de que o trabalhador dispõe de menos poder de contratar que as demais pessoas civis que não se enquadram na classe trabalhadora. Reforça-se que o trabalhador é uma pessoa com poder de negociar limitado, cujo limite é fixado para proteger a sua própria existência. Logo, o trabalhador não é livre para expor a sua vida a risco, em nome de um contrato de trabalho subordinado. Ou seja, ele não pode, motivado pela disposição de sua força de trabalho para a realização de determinada atividade econômica, entrar em contato físico com produtos cancerígenos. 
Carece de proteção, portanto, não somente pela constatada hipossuficiência, mas pelo sentido que o trabalho tem na construção da identidade e pelos riscos que comporta à saúde e à vida.

A questão é que o Direito, moldado sob o paradigma da certeza jurídica, institui a proteção ao trabalhador de acordo com os limites da racionalidade prevalecente, ou seja, atende à aferição material dos possíveis danos. O inevitável recurso à ideia de medidas e cálculo é adotada na formulação de prescrições de condutas laborais. Para isso, valeu-se do recurso mais adequado para justificar a proteção do Estado a determinados indivíduos: uma racionalidade baseada no cálculo de risco.

Cabia a difícil tarefa de identificar quais riscos o trabalho, da forma como era realizado, produzia à vida e à saúde. Disso resulta, ao longo de estudos sobre a segurança e a saúde do trabalhador, a definição e a relação dos agentes químicos, biológicos e físicos.

Além do corpo físico, o trabalho mantém-se como referência central na construção da individualidade, ou seja, no sentido que o indivíduo dá a si mesmo. Essa conclusão implica a discussão dos danos e riscos que o trabalho mal organizado e gerenciado pode gerar ao indíviduo-trabalhador. E aqui, mais do que uma análise de riscos físicos, químicos e biológicos produzidos pelo meio ambiente do trabalho, questionam-se os riscos desencadeados na dinâmica das relações humanas decorrentes do contrato de trabalho subordinado. A importância desse viés para o Direito reside no momento da seleção dos comportamentos esperados nas relações de trabalho subordinado, em que cabe indagar o que se pretende a partir da prescrição de condutas. Resta, pois, perquirir qual seria a função do Direito do Trabalho e, assim, compreender como o sistema juslaboral mantém sua integridade diante da complexidade semântica inerente à ideia de trabalho e a sua relação na construção do indivíduo.

\subsubsection{O indivíduo flexível}

O individualismo constitui elemento fundamental do paradigma da denominada modernidade. O desequilíbrio de forças na sociedade, decorrente da exploração de mão-deobra regida pelos contratos clássicos de Direito Civil, explicita-se nos modelos sociais desencadeados e propulsionados pela consciência de classe dos trabalhadores. A partir disso, as relações de trabalho subordinado assumem novo contorno: de contrato civil 
(locação de mão-de-obra, prestação de serviços ou mesmo compra e venda) passa a ser um contrato com características peculiares, de onde se extrai a noção de emprego: trabalho realizado sob ordens de outrem, pessoa física ou jurídica, mediante remuneração e disciplinado pelas normas de proteção, saúde e medicina emanadas pelo Estado.

Sem adentrar nos avanços e nos impactos dos movimentos coletivos dos trabalhadores, na forma de ação sindical, a disciplina normativa estatal configurou-se com base na ideia de indivíduo. A fim de manter o equilíbrio das relações sociais, a noção de igualdade entre os indivíduos foi substituída pela de hipossuficiência de um dos indivíduos da relação. O paradigma caracterizado pelo individualismo permaneceu como uma constante nas relações de trabalho e na formatação da dimensão normativa do trabalho.

A chamada "pós-modernidade" tentou reconciliar princípios como o de democracia e direitos humanos. Entretanto, como sustenta Gilles Lipovestky, "a pós-modernidade não terá sido mais que um estágio de transição, um momento de curta duração", e esse momento "já não é mais o nosso". ${ }^{267}$ Para o referido autor, vivencia-se a hipermodernidade, em que, "longe de decretar-se o óbito da modernidade, assiste-se a seu arremate (...) na exploração da razão instrumental até a 'morte' desta, numa individualização galopante". ${ }^{268}$ A hipermodernidade alicerça-se no trinômio mercado eficiência técnica - indivíduo. ${ }^{269} \mathrm{O}$ mercado de trabalho, para se adaptar aos postulados do paradigma, é desregulamentado, os empregos são precarizados e a "esfera profissional está na origem de uma maré crescente de sentimentos de insegurança, de desorientação, de dúvidas sobre si". ${ }^{270}$ A sobrevalorização da subjetividade promove o que Gilles Lipovestky denomina "indivíduo desarticulado", o qual "vive como um caso pessoal o que é uma realidade econômica e social". ${ }^{271} \mathrm{O}$ trabalhador, preocupado com sua adaptação às novas demandas, distancia-se dos demais indivíduos que partilham da mesma experiência. Para Joan Scott, as identidades de grupo são um fato da existência social e as possibilidades de identidades individuais repousam sobre elas, tanto em sentido positivo (pertencente a um grupo, o indivíduo participa da luta contra a discriminação do grupo e em favor de garantia

\footnotetext{
${ }^{267}$ LIPOVETSKY, Gilles. Os tempos hipermodernos. Trad. Mário Vilela. São Paulo: Ed. Barcarolla, 2004. p. 58.

${ }^{268}$ Id. Ibid., p. 53.

${ }^{269}$ Id. Ibid., p. 54.

${ }^{270}$ Id. A felicidade paradoxal: ensaio sobre a sociedade de hiperconsumo. Trad. Maria Lucia Machado. São Paulo: Companhia das Letras, 2007. p. 168.

${ }^{271}$ Id. Ibid., p. 169.
} 
de direitos), quanto negativo (nos processos de diferenciação social, o indíviduo é objeto de discriminação). ${ }^{272}$

A perda dos papéis, do resultado do trabalho, das funções a serem desempenhadas, enfim, o questionamento (ou mesmo impossibilidade de questionar e total indefinição) do valor do trabalho demonstra a fragmentação do homem-trabalhador. O resultado dessas mudanças é a falta de identidade e, consequentemente, da capacidade de agir, interagir, participar ativamente com o meio ambiente e com o outro. Perde-se, assim, o referencial para um discurso que reproduza os referenciais, os valores e os interesses dos trabalhadores, identificados como grupo social.

O trabalhador é submetido a uma contradição patente: exige-se dele a utilização de suas habilidades de acordo com as demandas do meio ambiente. Entretanto, o meio ambiente é variável e ao indivíduo é atribuída a responsabilidade pela definição de estratégias para a solução de eventuais problemas que a priori fazem parte da (des)organização do trabalho. Nesse universo, a subordinação, elemento fundamental do conceito de emprego, aparece camuflada nas relações de trabalho regidas pelo ordenamento jurídico estatal, pois o indivíduo-trabalhador passa a "participar" na criação de estratégias para organizar a dinâmica do trabalho. Dentro dessa óptica, é possível compreender a lógica de instituições bancárias que redimensionam seu quadro de empregados e erigem grande parcela deles na categoria de gerentes. Suscita-se a seguinte questão: o que e/ou quem esses "gerentes" gerenciam? A resposta que se apresenta é: o próprio trabalho realizado, como capacidade de se adaptar a uma organização de trabalho mutável e imprevisível, em que se gerenciam os problemas apresentados e a responsabilidade de dar as soluções.

Não cabe aqui discutir as implicações legais de práticas organizacionais como a supracitada, mas, em termos de uma dimensão normativo-sociológica, percebe-se uma transformação extremamente relevante e complexa: dos "homens-bois", de quem se exigiam "corpos dóceis"273, passa-se a "homens flexíveis", dotados de "mentes dóceis". São os "homens-flexíveis" indivíduos entregues apenas a si mesmos" ${ }^{274}$, cujas "mentes dóceis" os tornam capazes de se adaptar às situações imprevisíveis. A tese ontológica

\footnotetext{
${ }^{272}$ SCOTT, Joan. O enigma da igualdade. Revista de Estudos Feministas, Florianópolis, v. 13, n. 1, p. 18 e 29 , jan./abr. 2005.

${ }^{273}$ V. FOUCAULT, Michel. Vigiar e punir: história da violência nas prisões, cit., p 119.

${ }^{274}$ LIPOVETSKY, Gilles. A felicidade paradoxal: ensaio sobre a sociedade de hiperconsumo, cit., p. 169.
} 
sustenta-se e reforça-se na hipermodernidade: o indivíduo é racional (racionalidade precisa, objetiva, geométrica) e maximizador de resultados. E a subordinação persiste, exibida sob uma nova roupagem: não é mais imprescindível "dar ordens", mas deixar patente e permanentemente suspensa, como a espada de Dâmocles, a exigência de o indivíduo-trabalhador ser capaz de se adaptar às condições instáveis de trabalho.

Nesse cenário, formação profissional e qualificação, por exemplo, traduzem um modelo normativo estável, incompatível com a velocidade imprimida pela sociedade da informação. Sem referencial, o trabalhador arca com o ônus da modernidade (trabalho subordinado) com as agravantes da instabilidade e insegurança características da hipermodernidade $^{275}$. E resta a dúvida: como estar preparado para uma realidade cujos contornos não estão dimensionados?

\subsubsection{Organização do trabalho versus "desorganização" do indivíduo trabalhador}

No final do século XVIII e no século XIX, uma das principais preocupações na elaboração do discurso capitalista industrial era desatrelar o seu modelo de exploração de mão-de-obra dos modelos anteriores: escravidão e servidão. A noção de liberdade e igualdade sustentou o modo como o trabalho passou a ser organizado. Ainda que tenha sido reconhecida a desigualdade material entre as partes na relação de emprego, a subordinação do trabalhador frente ao empregador é entendida como elemento do contrato livremente celebrado, ou seja, a subordinação é jurídica.

O trunfo do exercício de poder na relação de trabalho subordinado reside na aparente ausência de coação. Exemplo disso é o taylorismo. Inspirado pelo positivismo científico, o engenheiro Frederick Winslow Taylor inaugurou a chamada "gerência científica". O objetivo era extrair o máximo da força de trabalho, mas com técnicas

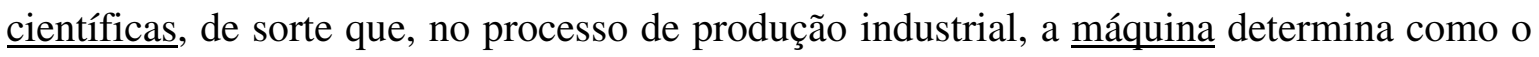
trabalho deverá ser realizado. A subordinação não se manifesta na coação explícita, mas implicitamente, por meio da exigência da realização do trabalho nos moldes como foi

\footnotetext{
${ }^{275 ، O}$ hiperindividualismo coincide não apenas com a internalização do modelo do homo oeconomicus que persegue a maximização de seus ganhos na maioria das esferas da vida (escola, sexualidade, procriação, religião, política, sindicalismo), mas também com a desestruturação de antigas formas de regulação social dos comportamentos, junto a uma maré montante de patologias, distúrbios e excessos comportamentais". (LIPOVETSKY, Gilles. Os tempos hipermodernos, cit., p. 56).
} 
“contratado", em síntese: na execução de atividades definidas, em um espaço físicotemporal determinado. O atendimento às cláusulas de trabalho "livremente pactuadas" é meticulosamente fiscalizado e a organização do trabalho é dirigida pelo empregador ou por alguém por esse designado. O homem-trabalhador assume a condição de mero "operário", terminologia que está indissociavelmente ligada à noção de máquina (objeto). O "trabalho humano que opera" é mais um fator no processo de produção.

Se as forças humanas são consideradas mercadorias (trabalho como fator de produção), elas são valorizadas não pela sua natureza (humana), mas pela sua capacidade de serem comercializadas (objeto de consumo). A liberdade do trabalhador reduz-se à possibilidade de se comercializar, conforme as circunstâncias e regras pré-estabelecidas. Como "objeto", o princípio racional da não-contradição impede que se considere o trabalhador como sujeito. E se não é sujeito, não lhe é possível atribuir responsabilidade para determinar suas ações. O trabalhador, visto sob essa óptica, passa por uma situação que lembra a do cidadão romano submetido a capitis diminutio: perdendo seu status libertatis, era reduzido a condição de res. Como res, o homem não se identifica consigo mesmo porque não tem poder para contribuir na transformação e/ou na formatação do campo social e, consequentemente, não se identifica com sua condição humana.

A partir do momento em que o indivíduo tem dificuldade de identificar-se consigo mesmo, ele perde a capacidade de ver o outro como ser humano. A capitis diminutio não está explícita, tal como se fazia presente no Direito Romano; permanece no inconsciente da sociedade. E a violência simbólica neutraliza o indivíduo, sem precisar de instrumentos explícitos de coação.

Com o advento de novas formas de organização de trabalho, passou-se a alegar que o trabalhador sem iniciativa - o subordinado - foi substituído pela mão-de-obra multiqualificada e capaz de tomar decisões. É modelo inaugurado pelo toyotismo, que parte de um projeto de "gestão participativa", trazendo o trabalhador para o campo das decisões empresariais. Essa possibilidade de participação do trabalhador na tomada de decisões aparentemente romperia com a subordinação, elemento pressuposto no paradigma da organização de trabalho capitalista industrial. Mitigada a ideia de subordinação, tornarse-ia desnecessário, pois, um aparato de proteção a um empregado não mais hipossuficiente e submetido a ordens. Justificar-se-ia, assim, a flexibilização das normas 
$\operatorname{trabalhistas}^{276}$. Mas as "novas gerências" não significam maior autonomia ao trabalhador; ao contrário, revisitam as condições de trabalho alienado, para atender às novas necessidades da sociedade capitalista. ${ }^{277}$ Ao trabalhador é atribuída a responsabilidade para ser polivalente e adaptável, capaz de executar atividades variadas, em um contexto espaçotemporal instável ou indefinido. Isso significa que as condições em que o trabalho é executado são imprevisíveis. Ao contrário do que se poderia afirmar, o trabalhador não participa ativa e deliberadamente do processo de decisão; não age, mas reage às pressões do ambiente. Ser "responsável" não é ser sujeito participante da construção da realidade, porém ser suficientemente flexível para lidar com o imprevisível.

O que obscurece a percepção da nova roupagem da subordinação nas relações de emprego é a despersonalização do poder. Esse não precisa ser confundido com o "de um ditador e de uma burocracia política a ele aliada, mas [refere-se] ao poder anônimo do mercado, do sucesso, da opinião pública, do 'senso comum' - ou melhor, da insensatez comum - e da máquina de quem passamos a ser servos" ${ }^{278}$. A esse respeito, Marcelo Afonso Ribeiro destaca a pressão a que está submetido o trabalhador, agravada pela ausência da presença física do opressor, e a confusão provocada pelos "discursos ideológicos geradores de consenso que transformaram em verdades a necessidade inevitável da reestruturação produtiva, da flexibilização, da globalização, da excelência do trabalho, do desemprego e da flexi-segurança". ${ }^{279}$

Circunstâncias da realidade sócio-econômica - muitas vezes retratadas nos chamados "momentos de crise" - subordinam o trabalhador à adoção de uma lógica de mercado. Na condição de "vendedor do seu produto", o trabalhador assume ainda a responsabilidade de se manter comercializável, ou melhor, de ser dotado de empregabilidade ${ }^{280}$. E esse discurso de poder é aceito acriticamente, na medida em que: a)

\footnotetext{
${ }^{276}$ O tema "flexibilização" será abordado no item 2.5. do Capítulo III deste estudo.

277، "Utiliza-se de novas técnicas de gestão da força de trabalho, do trabalho em equipe, das "células de produção', dos 'times de trabalho', dos grupos 'semi-autônomos', além de requerer, ao menos no plano discursivo, o 'envolvimento participativo' dos trabalhadores, em verdade uma participação manipuladora e que preserva, na essência, as condições do trabalho alienado e estranhado. $O$ 'trabalho polivalente', 'multifuncional', 'qualificado', combinado com uma estrutura mais horizontalizada e integrada entre diversas empresas, inclusive nas empresas terceirizadas, tem como finalidade a redução do tempo de trabalho." (ANTUNES, Ricardo. op. cit., p. 52).

${ }^{278}$ FROMM, Erich. Análise do homem. Trad. Octavio Alves Velho. 13. ed. Rio de Janeiro: Ed. Guanabara, 1986. p. 209.

${ }^{279}$ RIBEIRO, Marcelo Afonso. Psicologia e gestão de pessoas: reflexões críticas e temas afins (ética, competência e carreira). São Paulo: Vetor, 2009. p. 58.

280“Utilizada fundamentalmente como uma "buzzword" quer no plano da definição de políticas públicas orientadas pelo primado da individualização quer no plano dos discursos gestionários adeptos da
} 
transfere a culpa pelo fracasso à incapacidade de adaptação ao modelo (molde/uniforme) imposto; b) a subjetividade é valorizada sob a forma de uma sociedade competitiva; e c) o maior risco é imposição de um paradigma pautado na ausência de alteridade.

A flexibilização das instituições reforça o ideal de indivíduo abstrato e racional, pois quanto menos rígidas as instituições, menor a amplitude de práticas intersubjetivamente compartilhadas. E aqui destaca-se o ponto nevrálgico a ser ressaltado: historicamente, a valorização do individualismo no mundo do trabalho não contribuiu para a emergência de estabilidade e segurança sociais.

Ao contrário, qualquer modelo que se proponha a trazer soluções para os problemas oriundos do mundo do trabalho deverá partir de um enfoque de interação dinâmica entre os sujeitos do contrato de trabalho subordinado. Se os contornos de um novo paradigma ${ }^{281}$ ainda não estão claros e definidos, não é desarrazoado afirmar que o paradigma existente, centrado no individualismo, gerou "o sentimento de funcionamento defeituoso"282 . E é esse sentimento que autoriza a proposição de nova(s) hipótese(s).

Se o objetivo do homem for tornar-se um indivíduo conhecedor de suas potencialidades, valorizar o ser humano é a meta a ser perseguida pela sociedade. Para tanto, indispensável se torna a proteção dispensada ao trabalhador a fim de garantir o respeito à integridade biopsicológica do ser humano na esfera das relações de emprego. E disso resulta a importância e a principal função do Direito do Trabalho, como expressão dos direitos fundamentais sociais: evocar e contribuir para o processo de integração do homem à sua essência.

desregulamentação dos mercados, em particular do mercado de trabalho, o termo empregabilidade tem vindo a ser aceito acriticamente para legitimar uma visão do mundo ideologicamente centrada nas concepções neo-liberais". [grifo nosso] (ALMEIDA, António José. Empregabilidade, contextos de trabalho e funcionamento do mercado de trabalho em Portugal. Sísifo: revista de Ciências da Educação, Lisboa, n. 2, p. 52, jan./abr.2007. Disponível em: <http://sisifo.fpce.ul.pt>. Acesso em: 12. out. 2007).

${ }^{281}$ Por paradigma adota-se o conceito formulado por Thomas S. Kuhn, o qual já foi apresentado no item 1.1 do Capítulo I: “Considero 'paradigmas' as realizações científicas universalmente reconhecidas que, durante algum tempo, fornecem problemas e soluções modelares para uma comunidade de praticantes de uma ciência”. (KUHN, Thomas S. op. cit., p. 13).

${ }^{282}$ KUHN, Thomas S. op. cit., p. 126. 


\subsection{Do homem abstrato para o homem concreto}

O pensamento moderno liberal não enfrentou os obstáculos do exercício do poder presente nas relações privadas. ${ }^{283}$ Se a propriedade é função da liberdade, decorre que a variável de propriedade determina a quantidade de liberdade. É inevitável concluir que, não existindo naturalmente a equitativa distribuição da propriedade, a liberdade dos modernos constrói-se sobre a desigualdade entre os indivíduos. E ainda Norberto Bobbio conclui que, "não importa que o Estado seja liberal se a sociedade, não obstante, é despótica. Não importa se o indivíduo seja livre politicamente, se não é livre socialmente. Muito acima da não liberdade como submissão ao poder do príncipe, há a não liberdade como submissão ao aparato produtivo". ${ }^{284}$

\subsubsection{A liberdade como "propriedade"}

Se a liberdade compõe o "patrimônio" do indivíduo, a autonomia da vontade (como uma forma de expressão da liberdade) é função da propriedade. Se uma das partes detiver menos propriedade em face do outro, a declaração (como manifestação da vontade) de uma das partes contratantes pode não ser maximizadora do interesse desta e resultar em uma transação altamente desproporcional em termos de custo e utilidade, refutando a premissa de que o indivíduo é auto-interessado e maximizador de seu interesse. As relações de trabalho subordinado constituíram campo fértil para expor essas contradições. Basta imaginar um trabalhador que, motivado pela necessidade de alimentação, "declara a sua vontade" em se submeter a uma jornada de 18 (dezoito) horas, com comprometimento indiscutível à sua saúde.

O paradigma da modernidade centra-se no indivíduo livre, racional e autointeressado. E o indivíduo racional e auto-interessado, capaz de tomar as decisões que maximizam o bem-estar, não considera as externalidades no momento da tomada de

\footnotetext{
${ }^{283}$ A liberdade de não impedimento é resultado da antítese clássica do pensamento liberal: o Estado Absoluto e o Estado de Direito. Para os liberais, escreve Norberto Bobbio, "o problema da liberdade se resolve, sobretudo, na formação de um novo tipo de Estado, que é o Estado garantista e representativo". (BOBBIO, Norberto. Eguaglianza e libertà. Torino: Giulio Einaudi Editore, 1995. p. 85).

${ }^{284}$ BOBBIO, Norberto. Eguaglianza e libertà, cit., p. 86.
} 
decisão, ou seja, não releva as preferências e as influências do ambiente. Esse quadro ainda serve como paradigma.

A liberdade de agir, como a de trabalhar, foi afirmada incontestavelmente e, da mesma forma, a liberdade de ser proprietário. Contudo, no mundo sensível, liberdade de trabalhar e possuir, como condutas livres, afigurava-se como ilusão. É a não-liberdade nascendo da liberdade ${ }^{285}$. É o que a sociedade de massas traduz hodiernamente, elevando à última potência o paradigma liberal moderno. O contrato de trabalho do "operário" do século XVIII da Inglaterra e a estandardização dos contratos da sociedade de massas trazem em seu bojo uma similitude: a minimização ou a própria exclusão da autonomia da vontade do trabalhador.

O Estado Democrático de Direito visou dar novos contornos à noção de liberdade: a de agir politicamente. Como consequência inevitável, o ordenamento jurídico assimilou os reflexos do poder democrático: o "indivíduo" cede espaço ao "coletivo"; os "direitos subjetivos" passam a conviver com "direitos de todos os homens".

$\mathrm{Na}$ esfera do Direito do Trabalho, o reconhecimento da presença de um desnivelamento entre as partes, que impede a assunção dos moldes de contratação clássicos, levou à inserção do elemento subordinação como caracterizador do contrato de trabalho. Diante da subordinação, admitiu-se a proteção do trabalhador e a previsão de direitos irrenunciáveis. Entretanto, isso não afasta da subordinação o conteúdo de sujeição do trabalhador. Afirma-se na doutrina juslaboralista que a subordinação deve ser entendida, em sua natureza, como jurídica, decorrente de um contrato de trabalho. Ainda que a subordinação (ou melhor, a sujeição) econômica não seja totalmente repudiada, prevêem-se limitações ao exercício da autonomia da vontade para justificar a garantia de direitos sociais no âmbito das relações de trabalho. Como destaca Paulo Eduardo Vieira de Oliveira, o contrato de trabalho não se resume ao pagamento de salário, ao contrário, extrapola a seara patrimonial, dado que uma das principais finalidades das normas laborais é assegurar o direito à dignidade das partes envolvidas na relação de emprego: empregado e empregador. ${ }^{286}$ Portanto, conclui o autor que "a identificação da necessidade de proteção jurídica da dignidade do empregado aparece em múltiplas restrições ao exercício da

\footnotetext{
${ }^{285}$ FERRAZ JÚNIOR, Tércio Sampaio. Estudos de filosofia do direito: reflexões sobre o poder, a liberdade, a justiça e o direito, cit., p. 107.

${ }^{286}$ OLIVEIRA, Paulo Eduardo Vieira de. O dano pessoal no direito do trabalho. São Paulo: LTr, 2002. p. 87.
} 
autonomia contratual pelo empregador, incidindo e integrando o conteúdo do contrato de trabalho". 287

A ampliação dessa estrutura do sistema jurídico depende da evolução da sua organização. A realidade, porém, aponta para um Estado Social Democrático de Direito que apresenta limitações derivadas do paradigma de que é tributário. A sustentação da óptica individualista expõe as fragilidades do sistema jurídico, que muitas vezes encontra sérias dificuldades para fornecer respostas satisfatórias. Por exemplo: se da liberdade individual para trabalhar decorreu o direito humano ao trabalho, então esse direito poderia ser exigido individualmente, gerando obrigatoriamente uma sociedade de pleno emprego? Uma possível consideração, com base no exposto no item anterior, é que são os poderes contemplados nas relações de trabalho subordinado que determinam os contornos e os limites de ação das partes envolvidas.

Com menos liberdade em face do outro, a declaração de uma das partes contratantes pode resultar em uma transação altamente desproporcional em termos de custo e utilidade, refutando a premissa de que o indivíduo é auto-interessado e maximizador de seu interesse. As relações de trabalho subordinado constituíram campo fértil para expor as contradições do paradigma da modernidade. Até que ponto há egoísmo (vício privado, virtude pública) do trabalhador que, no exercício da sua liberdade de trabalhar, concorda, com base em uma declaração amparada juridicamente (da mesma forma que o é a liberdade de trabalhar), em executar atividades em um ambiente indiscutivelmente prejudicial à sua saúde? ? $^{288}$

Michel Foucault debruça-se sobre a transformação da noção de corpo humano em objeto, passível de ser apropriado e de suportar coerções. Assim descreve o autor sobre o processo de submissão dos denominados "corpos dóceis":

O corpo humano entra numa maquinaria de poder que o esquadrinha, o desarticula e o recompõe. Uma 'anatomia política', que é também igualmente uma 'mecânica do poder', está nascendo; ela define como se pode ter domínio sobre o corpo dos outros, não simplesmente para que façam o que se quer, mas para que operem como se quer, com as técnicas, segundo a rapidez e a eficácia que se determina. A disciplina fabrica

\footnotetext{
${ }^{287}$ OLIVEIRA, Paulo Eduardo Vieira de. op. cit., p. 87.

288،Em suma, uma vez a emancipação humana na esfera da criação intelectual [avanço tecnológico] e da produção de riqueza [proteção à propriedade] parecia que as ameaças à liberdade poderia originar-se apenas do único monopólio de cuja sociedade não conseguira ainda reduzir, que era o monopólio da força. Ao contrário, o problema da liberdade se põe hoje a um nível mais profundo, que é o nível dos poderes da sociedade civil". (BOBBIO, Norberto. Eguaglianza e liberta, cit., p. 86).
} 
assim corpos submissos e exercitados, corpos 'dóceis'. A disciplina aumenta as forças do corpo (em termos econômicos de utilidade) e diminui essas mesmas forças (em termos políticos de obediência). Em uma palavra: ela dissocia o poder do corpo (...). ${ }^{289}$

O corpo humano é mais uma máquina em ação no processo produtivo. O homem é fragmentado, dissecado e disposto como objeto a cumprir uma função ${ }^{290}$.

O apropriar-se do corpo do indivíduo é retirar deste a oportunidade de se conduzir livremente, no sentido literal. É condenar o outro à condição de instrumento da vontade muitas vezes incompreensível - pelo exercício do poder.

Da mesma forma que se reduz o corpo às engrenagens da maquinaria, os hodiernamente denominados contratos de adesão, que existem na esfera trabalhista no século XIX, expõe a prevalência da racionalidade econômica que caracteriza as relações e ações do homem moderno: como admitir a intenção do trabalhador em dispor sua força de trabalho em condições precárias? Há maximização do auto-interesse quando se expõe a saúde e a própria vida à extinção? Mas o trabalhador aceita (declara "sua vontade") cláusulas pré-definidas, premido pela necessidade de sobreviver e inserir-se na sociedade. O indivíduo, envolvido pela dinâmica das relações sociais, desconhece o sentido das atividades que realiza, pois não se identifica com elas, incluindo aqui o trabalho como realização humana.

Norberto Bobbio aponta o problema da liberdade na sociedade industrialmente avançada: o problema da liberdade nasce mais como uma questão interna do sistema político, mas do sistema social em sua complexidade. O homem, prossegue Bobbio, é privado na sociedade tecnocrática da sua liberdade humana no "sentido mais amplo da palavra, a liberdade de desenvolver todos os recursos da própria natureza".

\footnotetext{
${ }^{289}$ FOUCAULT, Michel. Vigiar e punir: história da violência nas prisões, cit., p. 119.

${ }^{290}$ Considerado como mero elemento do processo de produção, o resultado é a identificação e projeção da noção de máquina no corpo humano. Jeremy Rifkin lembra que os "trabalhadores ficaram tão emaranhados nos ritmos da maquinaria mecânica, que frequentemente descreviam sua própria fadiga em termos de máquina - queixando-se de estarem 'desgastados' ou passando por um 'esgotamento'. Agora, um número crescente de trabalhadores está tornando-se tão integrado aos ritmos da nova cultura do computador, que quando sentem-se estressados, sentem 'sobrecarga' e quando sentem-se incapazes de enfrentar a situação, 'se apagam' e 'dão uma parada', eufemismos que refletem a proximidade com que os trabalhadores se identificam com o ritmo imposto pela tecnologia do computador". (RIFKIN, Jeremy. O fim dos empregos: o declínio inevitável dos níveis de empregos e a redução da força global de trabalho. Trad. Ruth Gabriela Bahr. São Paulo: Makron Books, 1995. p. 206).
} 
No campo das relações econômicas, sem compreender o caminho que trilha, o homem, envolvido pela dinâmica social, desconhece o sentido das atividades que realiza, pois não se identifica com elas. É o que a sociedade de massas traduz contemporaneamente, elevando à última potência o paradigma liberal moderno. O contrato de trabalho do operário do século XVIII da Inglaterra, o Holocausto e a estandardização dos contratos da sociedade de massas trazem em seu bojo uma similitude: a fragmentação do homem, a minimização ou a própria exclusão da autonomia ou da noção de liberdade.

\subsubsection{O processo de significação do trabalho na sociedade complexa: o exemplo da noção de carreira}

Na sociedade capitalista industrial e pós-industrial, o trabalho não se reduz a ser um instrumento de mediação. Mais que a "atividade correspondente ao artificialismo da existência humana" ${ }^{291}$, o trabalho subordinado surge no contexto relacional, ou seja, implica a ação, a qual está atrelada à "condição humana da pluralidade" 292: "A pluralidade é a condição da ação humana pelo fato de sermos todos os mesmos, isto é, humanos, sem que ninguém seja exatamente igual a qualquer pessoa que tenha existido, exista ou venha a existir". 293

O trabalho, portanto, passa por um processo de significação para cada indivíduo, com base nas condições criadas pelo homem e dadas para o homem. Isto significa que os homens criam condições de existência e por elas são condicionados ${ }^{294}$. Com a valorização do objeto em relação ao sujeito, o capitalismo impinge uma visão determinista nas relações humanas: todos os homens são racionais, maximizadores de bem-estar e auto-interessados. O problema reside no olhar sobre o mundo real, o qual não comporta o "homem-abstrato"; embora unidos pela natureza humana, cada indivíduo cria suas condições - estruturantes para as dimensões objetivo-subjetivas da vida - e está condicionado por elas.

Para exemplificar os relevantes efeitos dessas considerações, passa-se a analisar brevemente a noção de carreira. Ligada intrinsecamente ao trabalho, a carreira aproxima-se

\footnotetext{
${ }^{291}$ ARENDT, Hannah. A condição humana. Trad. Roberto Raposo. 10. ed. Rio de Janeiro: Forense Universitária, 2001.p. 15.

${ }^{292}$ Id. Ibid., p. 17.

${ }^{293}$ Id. Ibid., p. 16.

${ }^{294}$ Id. Ibid., p. 17.
} 
mais do universo do indivíduo. De ajustamento a desenvolvimento vocacionais, a carreira, contudo, passa pelas condicionantes objetivas determinadas pelos modelos capitalistas de organização de trabalho. Daí ser possível afirmar que, embora a carreira seja individual, quem planeja e define os contornos é o contexto organizacional.

Dada a miríade de teorias acerca do tema "carreira", não caberia nesse ensaio tentar discorrer exaustivamente sobre as transformações pelas quais a noção de carreira passou. Recorrer-se-á à denominada carreira proteana, que busca situar a transformação vivenciada no presente e delinear uma eventual futura concepção sobre carreira. Cabe apenas pontuar que a dificuldade de conceber a carreira na atualidade está na mudança dos seus contornos: se no passado eram rígidos e a carreira se materializava como um produto ou resultado final a ser alcançado, atualmente a carreira apresenta-se como um processo individualizado.

Justifica-se o modelo pautado no individualismo como um mecanismo epistemológico que, ao reduzir a complexidade, permite uma maior compreensão do objeto sob análise. Mas cresce em importância um problema irrefutável: na medida em que, como escreve Hannah Arendt, a condição humana pressupõe a pluralidade, conseguirão a estrutura e a organização do mercado de trabalho realmente absorver uma noção de carreira individualizada? Se não é possível deslindar essa questão, é possível antever que o enfoque no estudo do trabalho humano - aqui limitado à apreensão da noção de carreira não pode se reduzir à esfera individual.

Restringir a carreira ao universo do indivíduo é desconsiderar a ação humana como instância vital. A relação entre os indivíduos, os vínculos estabelecidos entre eles, as dimensões político-familiares, enfim a condição humana é inafastável da análise do trabalho e, por conseguinte, da carreira. Por exemplo, a concepção de carreira, como processo, é construída a partir de relações entre o indivíduo, os demais e as condições da existência humana, condições essas a que se refere Hannah Arendt ${ }^{295}$.

O processo de humanização do trabalho, porém, não pode refletir um mecanismo sofisticado de exploração da mão-de-obra. Os discursos das formas de gestão participativas evocam elementos que fizeram parte da luta dos trabalhadores, como "autonomia", "participação", "trabalho em equipe". O emprego desses termos no discurso dos trabalhadores visava ao reconhecimento do homem-trabalhador, visto não somente como

${ }^{295}$ ARENDT, Hannah. op. cit., p. 17. 
mais um fator de produção. Contudo, o que ocorreu, conforme observa a psicóloga Márcia Hespanhol Bernardo, em treze anos de trabalho no Centro de Referência em Saúde do Trabalhador, foi a apropriação e adaptação dos mesmos termos pelo discurso empresarial, resultando em flexibilidade no sentido das palavras de acordo com os interesses da empresa $^{296}$.

O distanciamento das práticas organizacionais de uma "concepção e prática do trabalho enquanto estrutura relacional e definidora do ser humano" gera "uma certa ambiguidade nas interpretações sobre a humanização do trabalho" ${ }^{, 297}$. Esse quadro não se apresenta claramente no quotidiano das relações de trabalho subordinado - cuja dominação é mascarada pelos discursos de gestão empresarial -, mas se mostra e se evidencia nos efeitos que provoca.

A compreensão desse contexto, portanto, tem de perpassar pelo não-metrificável e não-objetivado, e envolve imagens, símbolos e mitos que traduzem o interior do homem. A partir do mito, o homem pode compreender melhor os medos e as questões essenciais da humanidade, inclusive o universo do trabalho: "Modernamente, os mitos são considerados como expressão de modalidades de vida, modelos que possibilitam ao homem inserir-se na realidade, sendo protótipos de todas as atividades humanas dotadas de significação" 298.

A partir dessas considerações e com base na noção de carreira proteana, dois mitos auxiliam na configuração da carreira e, portanto, na concepção do significado do trabalho. A partir dessa perspectiva, a questão resulta assim apresentada: como se processa a transição da figura do trabalhador-Sísifo para o trabalhador-Proteus?

\footnotetext{
${ }^{296}$ MORAES, Aline. Trabalhadores vivenciam novo contexto de trabalho com maior exploração. Agência USP de Notícias, 01 fev. 2007. Disponível em: <http://www.usp.br/agen/repgs/2007/pags/010.htm>. Acesso em: 03 ago. 2010. Pode ser citado como exemplo da flexibilidade de sentido o emprego do termo "trabalho em equipe" pelo discurso empresarial: "Trabalho em equipe representa, na verdade, um agrupamento de trabalhadores para a realização de determinada tarefa. O real significado do termo conflita com o contexto de competição e individualização do trabalho que, por sua vez, entra em choque com a ideia de 'família empresa', que o discurso empresarial procura enfatizar. Segundo a psicóloga, existe até uma linguagem própria, que sustenta esse discurso ao criar uma "nova" atmosfera de trabalho. No lugar de funcionário, utiliza-se 'colaborador'; ao invés de chefe, fala-se em 'líder'; não existe objetivo, e sim "missão'." A conclusão a que chega a psicóloga Márcia Hespanhol Bernardo é de "'os temas introduzidos no discurso empresarial nada têm a ver com humanização, e sim com a exploração máxima da força de trabalho'(...) 'O discurso de mudança serve para manter tudo como está'." (MORAES, Aline. op. cit.)

${ }^{297}$ LANER, Aline dos Santos. op. cit., p. 80.

${ }^{298}$ PRADO, Lídia Reis de Almeida. O juiz e a emoção: aspectos da lógica da decisão judicial. 2. ed. Campinas: Millenium Ed., 2003. p. 128. Ainda: "O mito não é exatamente uma crença e menos ainda um ato de fé; é a experiência cotidiana, o imaginário vivido, o modo de relação dos homens consigos mesmo, com o mundo e com o outro". (SANTOS, Maria Celeste C. Leite. op. cit., p. 116).
} 


\subsubsection{De Sísifo a Proteus: as metáforas da pós/hipermodernidade}

Albert Camus compara a situação retratada no mito de Sísifo com a do operário que trabalha todos os dias de sua vida, executando as mesmas tarefas. ${ }^{299}$ Sísifo traduz a realidade do trabalhador concebido pelo capitalismo moderno. E o mito assume maior relevância em uma sociedade do trabalho em constante transformação.

Sísifo, rei de Corinto, é condenado pelos deuses a rolar manualmente uma rocha até o cume de uma montanha, a qual, pouco antes de alcançar o ápice e movida por uma força irresistível, retornaria ao pé da montanha. O eterno retorno da pedra, laboriosamente elevada ao cume da montanha, corresponde ao cotidiano do trabalho metódico, técnico e diligente exigido pela sociedade capitalista. Sísifo traduz a realidade do trabalhador concebido pelo capitalismo moderno. Ele reconhecia sua condição de eterno trabalhador, mas sua relação estava definida: a tarefa foi prescrita por uma autoridade conhecida (“deuses" como patrões determinados); a exploração psicobiológica foi limitada com a prescrição da tarefa (Sísifo sabia qual a quantidade de esforço e dedicação que lhe seriam cobrados); e a relação era estável (estabilidade). Não se discute que esse modelo acarretou rigidez. A partir desse modelo, a carreira se traduz como ajustamento do indivíduo à função a ser desempenhada, de sorte que se estabelece um vínculo estável, permanente entre o indivíduo e o trabalho.

Sísifo cedeu espaço à figura de Proteus. Em sua condição de imortal, Proteus tinha por característica conhecer o passado, presente e o futuro, mas não lhe agradava contar o que descobria. Aqueles que desejam consultá-lo tinham de surpreendê-lo e amarrá-lo durante a sesta. Entretanto, mesmo aprisionado, ele detinha a capacidade de assumir várias formas ${ }^{300}$. Proteus, portanto, era auto-suficiente. Ao contrário de Sísifo, Proteus é um deus. Dotado de infinita criatividade, a tarefa de transmudar-se não é definida, pois depende das circunstâncias. Sendo assim, a utilização de seus recursos pode ser explorada de forma ilimitada. Sem condições estáveis, pois a qualquer momento pode ser alvo de ataque, Proteus vale-se da sua polivalência. Comparar a carreira ao mito de Proteus é retornar à visão do homem-abstrato, do indivíduo racional, auto-interessado e maximizador de seus interesses.

\footnotetext{
${ }^{299}$ CAMUS, Albert. O mito de Sísifo. 4. ed. Rio de Janeiro: Record, 2007. p. 139.

${ }^{300}$ PROTEUS. Encyclopædia Britannica. 2009. Encyclopadia Britannica Online. Disponível em: <http://www.britannica.com/EBchecked/topic/480043/Proteus>. Acesso em: 31 maio 2009.
} 
Concepções como a da carreira proteana são consequência da menor importância dada ao trabalho como um objeto a ser apropriado pelo empregador. Se não interessa a propriedade do trabalho, o trabalhador pode ser "dono de si mesmo". Assume a condição de "deus" e, portanto, com poder para definir seu "destino". O que se observa de mais intrigante é sempre a tentativa de privilegiar a "individualidade" e não a noção de coletividade, quando se debruça sobre os problemas do trabalho. O trabalhador é pensado individualmente. Mas o que se percebe é que qualquer modelo que se proponha a trazer soluções para os problemas oriundos do mundo do trabalho deverá partir de um enfoque coletivo. As relações de trabalho e seus conceitos - como a carreira - são uma construção social e - frise-se - com implicações para além do mundo do trabalho. Enfim, a condição humana imprescinde da noção de ação. E o agir - a exemplo da atribuição de sentido às coisas - depende da interação com o outro. Nesse contexto de alteridade, é possível configurar o trabalho com sentido humano legítimo. 


\section{CAPÍTULO III. CONSIDERAÇÕES SOBRE UMA DAS FORMAS DE ATUAÇÃO ESTATAL: A CONVIVÊNCIA ENTRE OS "INTERESSES PRIVADOS" E O SISTEMA FEDERAL DE FISCALIZAÇÃO DO TRABALHO}

\section{O papel da fiscalização do trabalho no Brasil}

As relações de trabalho subordinado, como foi analisado até o presente momento, são pautadas por um cenário complexo e marcado por conflito de interesses. A própria concepção de trabalho assume seus contornos de acordo com a perspectiva adotada pelo sujeito: como exploração de um fator de produção ou instrumento de garantia de sobrevivência. A presença do Estado como mecanismo de promoção da segurança e paz sociais faz-se necessária no âmbito das relações de trabalho subordinado, na forma da legislação trabalhista e de instrumentos de verificação do cumprimento das normas pelos particulares. Nessa seara, desponta o papel da fiscalização do trabalho.

\subsection{Da dominação física à organização do trabalho}

A concepção de trabalho corresponde às referências do sujeito-observador que participa da construção de sentido. Os impactos provocados por uma ou outra perspectiva são determinados pelo exercício do poder dos atores sociais no curso das relações de trabalho subordinado. O que se verificou no início da industrialização, no século XVIII, na Inglaterra, foi o sobrepujamento da vontade dos detentores dos meios de produção em face daqueles que somente detinham o trabalho como instrumento para produzir bens. Para alicerçar a hegemonia dos proprietários dos bens de produção, adotou-se uma forma de representação do indivíduo em sociedade, "caracterizada por uma liberdade sem limites, por sua vontade de possuir o mundo". ${ }^{301}$ Nesse contexto, "a lógica econômica é aceita sem

\footnotetext{
${ }^{301}$ GOSDAL, Thereza Christina. Dignidade do trabalhador: um conceito construído sob o paradigma do trabalho decente e da honra. 2006. Tese (Doutorado em Direito) - Universidade Federal do Paraná, Curitiba, 2006. p. 10.
} 
reservas, assim como os primados da produção e do crescimento". ${ }^{302}$ A lógica econômica, por sua vez, impõe seus parâmetros e, a partir dela, a produção e a técnica passam a ocupar o centro de interesses da sociedade. Na organização do sistema capitalista, o indivíduo e a sua existência são instrumentalizados.

Se a produção e o crescimento são os objetivos a serem perseguidos pela ordem econômica, há de se perquirir o fundamento que sustenta essa preferência em detrimento de outros objetivos. Constata-se que a estratégia depende de um princípio jurídico, o qual passa a ser a liberdade individual. A partir da ideia de liberdade individual, rejeita-se a interferência do Estado na esfera alheia e, acima de tudo, afasta-se "qualquer demanda de prestação que não seja economicamente mensurável". ${ }^{303}$

Porém, à relevância dos objetivos econômicos soma-se a importância que a forma de organização das forças produtivas e as relações de produção assumem como base cultural da humanidade, "interferindo na construção de identidades dos indivíduos e das classes sociais, a nível simbólico, cultural, econômico e estrutural". ${ }^{304}$ Por essa razão, a degeneração das condições de trabalho e, consequentemente, da vida do trabalhador foi objeto no decorrrer da História de preocupação, uma vez que a inviabilidade de condições de existência minimamente dignas do trabalhador corromperiam a concepção mesma de ser humano.

Mesmo no século XVII, Jean-Baptiste Colbert, ministro do Estado e da economia do rei Luís XIV, estava convencido de que, para favorecer o progresso da indústria e da exportação, era necessário afastar a fraude, a negligência ou a ignorância, por meio de regras precisas e severas, estabelecendo, sobretudo para as tecelagens, a uniformidade de produtos. ${ }^{305}$ Colbert percebeu que para assegurar a execução das regras era necessário instituir o que denominou "commis genéraux des manufactures", correspondentes aos “inspetores de trabalho”, encarregados de fazer aplicar as leis do Estado. ${ }^{306}$

A relação entre trabalho e promoção de condições de vida dignas, por si só, apresenta-se como um dado construído historicamente. No Brasil, por exemplo, pensar em condições dignas de trabalho dependeu de um fato histórico determinante para a própria

\footnotetext{
${ }^{302}$ GOSDAL, Thereza Christina. op. cit., p. 11.

${ }^{303}$ Id. Ibid., p. 12.

${ }^{304}$ Id., loc. cit.

${ }^{305}$ BRIZON, Pierre. Histoire du travail et des travailleurs. 4.ed. Bruxelles: Édition de L'Églantine, 1926. p. 162.

${ }^{306}$ Id. Ibid., p. 177.
} 
reestruturação e possibilidade de ampliação do campo econômico nacional: a abolição da escravatura. Conforme já foi apontado, a prevalência dos interesses econômicos baseou-se em um primado: a liberdade individual. No contexto da escravidão, faltavam, então, dois pressupostos: a noção de indivíduo e de liberdade. Porém, aqui os traços da questão da formação da classe trabalhadora brasileira podem ser lançados. A abolição da escravidão não significou exatamente a mudança do paradigma de exploração do trabalho humano, e sim representa alteração da propriedade da mão-de-obra, que passa a ser juridicamente do trabalhador. Celso Furtado destaca que a importância da escravidão se prestava mais como base de um sistema regional de poder do que como forma de organização da produção. $\mathrm{O}$ resultado da abolição, ainda segundo o autor, é a ausência de profundas modificações de "real significação na forma de organização da produção e mesmo na distribuição de renda". ${ }^{307}$ Gilson Schwartz aponta que mesmo o movimento de urbanização "desde cedo criou outras formas de populismo e os coronéis da política de currais eleitorais apenas foram "modernizados"”. 308 A construção da liberdade não se opera nesse cenário e se consubstancia mais em discurso formal amparado nas experiências estrangeiras.

Isso tem relevância quanto à disciplina jurídica do trabalho, tendentes à manutenção do sistema do econômico, não necessariamente pela forma de produção, mas pelo exercício do poder. Nessa esteira, no entendimento de Gilson Schwartz, mesmo a civilização urbana brasileira não representou um "big bang", mas a expansão do universo do "bang bang", em que "a manipulação fascista das massas convive com a criminalização das favelas e a "ratanização da cidadania"," 309

A temática do poder motiva o modelo normativo de proteção ao trabalhador. Cabe, então, discutir a transformação promovida quando o poder personificado do empregador nos moldes de uma sociedade arcaico-patriarcal, como o era a agrária e a recémindustrializada - dá espaço ao poder "anônimo" exercido pela forma de produção. A metamorfose da representação do poder é decorrência do fato de que o poder não é atributo de uma classe de indivíduos. Já afirmava Foucault que o poder mais se exerce do que se possui; não é privilégio de uma "classe dominante", mas “o efeito conjunto de suas

\footnotetext{
${ }^{307}$ FURTADO, Celso. Formação econômica do Brasil. 27. ed. São Paulo: Companhia Ed. Nacional; Publifolha, 2000. p. 145. (Col. Grandes Nomes do Pensamento Brasileiro).

${ }^{308}$ SCHWARTZ, Gilson. Guia de Leitura. Celso Furtado, urgente e fora de moda. In: FURTADO, Celso. op. cit., p. 268.

${ }^{309}$ Id. Ibid., p. 269-270.
} 
posições estratégicas", como manobras, disposições, táticas, técnicas e funcionamentos ${ }^{310}$. A forma de organizar o trabalho pode constituir uma técnica de dominação.

Leonardo Mello e Silva destaca, então, que a reestruturação produtiva em curso ativa formas privatizantes de representação do mundo do trabalho e inviabiliza sistemas de bem-estar, fato esse que impinge um sistema de regulação das relações de trabalho e de proteção com contornos mercantis. Para o referido autor, o resultado disso é a contraposição entre um registro público (o Estado, por exemplo, via atuação do Ministério do Trabalho) e um registro privado em que estão situados os empregados e o empregador $^{311}$.

O paradigma mecanicista, técnico-científico e cartesiano desencadeia dilemas enfrentados no ambiente de trabalho decorre, pois, ao separar o sujeito do objeto, fragmenta os laços sociais e impõe ao indivíduo "a competitividade e o espírito individualista como sendo a única lógica possível para o mundo do trabalho, instaurando uma injustiça social, justificada pelo ideal liberal da meritocracia e eclipsada pela culpabilização individual" ${ }^{\text {312 }}$. Exemplo disso é, conforme foi visto, o discurso da empregabilidade.

Nas relações de trabalho, as estruturas de poder têm sofrido alterações resultantes das mudanças implementadas continuamente na organização do trabalho. A despersonalização do empregador - que se observa no mundo do trabalho atualmente - é um fenômeno imperativo das relações de trabalho, pois determina a perda de referencial do trabalhador sobre os traços do empregador. Transfigura-se, assim, o próprio conflito natural existente nas relações de trabalho: não existiria mais o "patrão", mas uma "força irresistível e de forma indefinida". Vislumbra-se o apogeu da sofisticação do funcionamento dos mecanismos de burocratização do poder, consubstanciada na organização técnica do trabalho como instrumento de dominação.

\footnotetext{
${ }^{310}$ FOUCAULT, Michel. Vigiar e punir: história da violência nas prisões, cit., p. 26.

${ }^{311}$ SILVA, Leonardo Mello e. Trabalho e reestruturação produtiva: o desmanche da classe. In: OLIVEIRA, Francisco de; RIZEK, Cilebe Saliba (Orgs.). A era da indeterminação. São Paulo: Boitempo, 2007. p. 9-10.

${ }^{312}$ RIBEIRO, Marcelo Afonso. op. cit., p. 81.
} 


\subsection{Por uma organização digna do trabalho}

Onde havia exercício claro da autoridade - com identidade da fonte de dominação e coação -, hoje há supressão da liberdade pela violência simbólica, difícil ou impossível de ser mensurada. O individualismo esfacela a consciência do trabalhador acerca do seu papel social e os mecanismos/instrumentos tradicionais (exemplo da greve) não chegam a produzir os mesmos resultados em face dessa forma de poder. Com o individualismo, rompe-se com a solidariedade característica da noção de classe trabalhadora; do trabalhador, submetido à organização taylorista-fordista, não era exigida individualidade (avaliação por competências) ${ }^{313}$. Leonardo Mello e Silva pondera que não se trata de “deplorar o velho mundo", mas "atentar para a nova recombinação do social entre o eu e o nós que provavelmente se assentará" e, especialmente, "para o novo componente de poder e de assujeitamento" presente nas atuais formas de organização do trabalho ${ }^{314}$.

Atualmente a preocupação não é identificar no quadro social quem detém o poder, mas o que impede o exercício da liberdade. Lograr êxito nessa tarefa depende de uma mudança de enfoque: do modelo de redução da complexidade para a compreensão da dinâmica da complexidade.

Dada a natureza contratual da relação de trabalho subordinado, reconhecer essa realidade é um importante passo para investigar o impacto do papel do empregador na organização do trabalho e determinar juridicamente quais os mecanismos/instrumentos hábeis para corrigir eventuais desajustes ou desequilíbrios que comprometam a promoção dos princípios constitucionais de proteção ao trabalho.

A Consolidação das Leis do Trabalho em seu artigo $2^{\circ}$, caput, conceitua empregador como sendo a empresa. Mas o conceito formal da lei não impulsiona a mudança estrutural das relações de poder, embora os políticos e os demagogos, já alertava Sérgio Buarque de Hollanda, "acreditam sinceramente que da sabedoria e sobretudo da coerência das leis depende diretamente a perfeição dos povos e dos governos". ${ }^{315}$ Nada mais adaptado à ideia de "absolutismo da razão"316 e com a "ideia de bondade natural do

\footnotetext{
${ }^{313}$ SILVA, Leonardo Mello e. op. cit., p. 97.

${ }^{314}$ Id., loc. cit.

${ }^{315}$ HOLLANDA, Sérgio Buarque de. Raízes do Brasil. 2. ed. São Paulo: Companhia das Letras, 2007. p. 179.

${ }^{316}$ Id. Ibid., p. 178.
} 
homem"317 que caracterizam o liberalismo econômico. Falta a essa teoria a emotividade que dinamiza as relações; ao contrário, o liberalismo econômico, de acordo com Sérgio Buarque de Hollanda, é uma teoria essencialmente neutra e, por isso, é facilmente enquadrada em fórmulas ${ }^{318}$. E, por conta disso, enfrenta-se um dos maiores desafios: garantir a integridade do sistema juslaboral, identificando sua essência organizacional e a natureza dos seus elementos. Do contrário, corre-se o risco de ruptura do sistema laboral. As influências externas ao sistema de normas trabalhistas põem em xeque a própria eficiência a que visa a Economia.

Como destaca Gilson Schwartz ao analisar a obra de Furtado:

A sua lição maior está num alerta: os mecanismos que parecem puramente econômicos, num país ou em escala global, são na realidade instrumentos de força de uma classe social. ${ }^{319}$

Como uma construção promovida ao largo da História, a valorização do trabalho foi difundida mais como uma estratégia para legitimar o sistema capitalista, a fim de justificar pelo trabalho a apropriação privada e a acumulação. ${ }^{320}$

Quando se inicia o processo de reconhecimento de direitos humanos, o enfoque concentra-se, precipuamente, na liberdade e na igualdade dos indivíduos, presumidamente racionais e capazes de garantir a plena satisfação dos seus interesses. Fábio Konder Comparato lembra que o movimento pela Independência - que resultou na Constituição dos Estados Unidos da América do Norte - e a Revolução Francesa de 1789 se ocuparam com motivos diferentes. Enquanto não se pode falar propriamente de uma "Revolução Americana", o termo "revolução" é apropriado ao movimento desencadeado na França de 1789, na medida em que, a partir desse evento histórico, a palavra assumiu o conteúdo semântico de "renovação completa das estruturas sociopolíticas, a instauração ex novo não apenas de um governo ou de um regime político, mas de toda uma sociedade, no conjunto de relações de poder que compõem a sua estrutura" ${ }^{, 321}$. Por outro lado, a denominada "revolução americana", segundo expõe Comparato, visou à restauração "das antigas e

\footnotetext{
${ }^{317}$ HOLLANDA, Sérgio Buarque de. op. cit., p. 185.

${ }^{318}$ Id., loc. cit.

${ }^{319}$ SCHWARTZ, Gilson. op. cit., p. 269.

${ }^{320}$ GOSDAL, Thereza Christina. op. cit., p. 55.

${ }^{321}$ COMPARATO, Fábio Konder. A afirmação histórica dos direitos humanos, cit., p. 123.
} 
costumeiras prerrogativas dos súditos norte-americanos da coroa britânica"322. Não obstante as diferenças, ambas as Revoluções visaram à consolidação do liberalismo econômico.

Após esses enunciados, conclui-se que o trabalho, no contexto do sistema capitalista liberal, se converteu em mercadoria, com valor próprio, destacado da natureza humana que, necessariamente e intrinsicamente, o contém. Thereza Christina Gosdal observa que "a evolução legal acompanhou e instrumentalizou uma mudança da compreensão do que seja trabalho e do que seja dignidade", de forma que a dignidade passou a compreender condições mínimas de existência, importando no acesso a bens e serviços e a possibilidade de ser proprietário de pelo menos sua força trabalho. ${ }^{323}$ Mas a liberdade, em termos de cidadania ativa ${ }^{324}$, não se efetiva na prática pós-abolição ou com a proclamação da República no Brasil. Mantém-se a concepção privatística de propriedade na construção da concepção de trabalho.

Da mesma forma que a noção de trabalho sofre um processo de acomodação ao sistema de produção capitalista, os direitos humanos também não são um a priori, e sim o resultado de uma evolução histórica, em que se travaram confrontos derivados da disparidade entre os padrões de referência de empregados e empregadores, conforme foi analisado no capítulo antecedente.

Com vistas a estimular condutas, a ampliação do conteúdo dos direitos humanos, portanto, é resultado de um processo de adaptação de influências externas ao sistema jurídico, como resultado de estímulos produzidos no seio da sociedade, que, mesmo focado no ponto de vista estritamente econômico: a) atenda aos desejos e preferências, por meio da alocação eficiente de recursos; b) estabeleça condições de emergência de cooperação entre os atores sociais, com o objetivo de promover a equidade ${ }^{325}$.

\footnotetext{
${ }^{322}$ COMPARATO, Fábio Konder. A afirmação histórica dos direitos humanos, cit., p. 123.

${ }^{323}$ GOSDAL, Thereza Christina. op. cit., p. 56.

${ }^{324}$ Maria Victoria de Mesquita Benevides explica que por "cidadania ativa" entende-se "a participação popular como possibilidade de criação, transformação e controle sobre o poder, ou os poderes". (BENEVIDES, Maria Victoria de Mesquita. A cidadania ativa: referendo, plebiscito e iniciativa popular. 3. ed. São Paulo: Ática, 2002. p. 20). Essa participação, segundo a autora, não se esgota na escolha para cargos executivos e legislativos, mas também inclui a participação em atividades administrativas, como a participação de trabalhadores na gestão das empresas. (Id. Ibid., p. 18).

${ }^{325}$ Anotações das aulas do Prof. J.R.N.Chiappin, intitulada Direito e economia, na disciplina de pósgraduação, oferecida no segundo semestre de 2008 e ministrada na Faculdade de Economia da Universidade de São Paulo.
} 
Ocorre que nem sempre é possível essa adaptação ao sistema e corrompem-se os próprios objetivos econômicos. Exemplo disso foi a aprovação da Lei de Peel, em 1802, na Inglaterra. Trata-se da primeira lei de proteção ao trabalho, destinada aos menores pobres e órfãos que trabalhavam nas tecelagens como aprendizes. A iniciativa para a elaboração da lei de Peel teve inspiração na morte de vários aprendizes submetidos a condições péssimas de trabalho nas tecelagens. Ou seja, não se constatava eficiência no modo de produção (perda da mão-de-obra), tampouco se estabeleciam condições de cooperação entre os atores sociais. Porém, essa primeira tentativa de intervenção nas relações de trabalho não foi exitosa, o que se justifica, por exemplo, pelo fato de a inspeção do cumprimento da lei ser facultativa. ${ }^{326}$ Em 1833, ainda na Inglaterra, é aprovada a Lei de Althorp, considerada o "marco inicial da Inspeção do Trabalho, compreendida como órgão do Estado instituído para regular as relações do trabalho", sendo que o impacto positivo da lei culminou, em 1844, na seperação das funções administrativas (atribuídas aos inspetores) das judiciais (destinadas aos juízes). ${ }^{327}$

\subsection{A importância da fiscalização do trabalho}

De acordo com o que já foi apresentado, ao modelo de indivíduo racional agrega-se o de Estado, como parte da solução do problema fundamental da alocação eficiente e equitativa dos bens escassos na sociedade. Entre esses bens, a partir do trabalho assalariado, está a força de trabalho, como propriedade do indivíduo sem meios de produção, mas paulatinamente se reconhecem a saúde e a vida do ser humano que dispõe do seu trabalho a outrem. E o Estado, a exemplo do que ocorreu na inexitosa Lei de Peel, assume sua condição de mecanismo institucional, situado ao lado das estruturas do mercado, no sistema econômico, porém atuando concomitantemente como parte fundamental da organização do sistema político na sociedade civil e, nesse âmbito, impõe restrições, amparado por um sistema jurídico. Por isso, em um modelo de Estado que visa à garantia da vida, com proteção da liberdade e propriedade, o sistema jurídico tem a função

\footnotetext{
${ }^{326}$ BIGNAMI, Renato. A inspeção do trabalho no Brasil: procedimentos especiais para a ação fiscal. São Paulo: LTr, 2007. p. 25.

${ }^{327}$ Id., loc. cit.
} 
de conferir mecanismos, instrumentos, consubstanciados nas normas jurídicas, cujo papel, portanto, é incentivar condutas ou alterar comportamentos. ${ }^{328}$

Nelson Mannrich aponta que a intervenção estatal ganha maior espaço a partir do último quarto do século XIX. Segundo Mannrich, a Alemanha, em 1882, a Espanha, em 1883, os Estados Unidos, em 1883, o Reino Unido, em 1884, a França, em 1891 e a Bélgica, em 1894 contam departamentos ou repartições que se tornariam posteriormente em ministérios do trabalho. ${ }^{329}$ Se os países industrializados já dispunham de um sistema de fiscalização de cumprimento da legislação do trabalho, tais sistemas não mantinham entre si um padrão de atuação. ${ }^{330}$

A partir de iniciativas dessa natureza, o intervencionismo estatal amplia seu campo de atuação e assume importante papel na fiscalização do cumprimento das normas de proteção ao trabalho, as quais começam a ser inseridas nos ordenamentos jurídicos. $\mathrm{O}$ fenômeno conhecido como Constitucionalismo Social inaugura um movimento de gradativo reconhecimento de direitos dos trabalhadores como direitos fundamentais. Ícones desse fenômeno jurídico são as Constituições do México de 1917 e a de Weimar de 1919, as quais alçaram os direitos sociais dos trabalhadores ao status constitucional ${ }^{331}$.

É importante frisar que as relações de trabalho subordinado ocorrem em um ambiente moldado pela influência do padrão de referência de uma das partes da relação: o empregador. Logo, as relações de trabalho subordinado desenvolvem-se no contexto da ideia de propriedade, mas não são configuradas com base na "propriedade" da força de trabalho do empregado, e sim na propriedade do empregador. E, em face disso, acentua-se a complexidade da análise dessas relações pela presença de múltiplos direitos fundamentais em questão, a exemplo da convivência do direito de propriedade com o direito à saúde e à vida digna. Poderia o empregador sob os auspícios do seu direito de propriedade submeter o trabalhador a risco de dano à saúde, ao adquirir uma máquina cujos perigos de mutilação não foram avaliados? Ou o Estado poderia, então, se valer do

\footnotetext{
${ }^{328}$ Cf. anotações das aulas do Prof. J. R. N. Chiappin Direito e economia, cit.

${ }^{329}$ ORGANIZAÇÃO INTERNACIONAL DO TRABALHO. Inspeção do trabalho: manual de educação do trabalhador. Trad. Edilson Alkmin Cunha. São Paulo: LTr, 1994. p. 16.

${ }^{330}$ Id. Ibid., p. 17.

${ }^{331}$ Também merece destaque a Declaração e a Constituição soviética de 1918. A exemplo das Constituições do México e de Weimar, limitou o exercício do direito à propriedade privada, conferindo ao Estado o direito-dever de "garantizar la función social de la propiedad y a tal fin se le conferirán los instrumentos de poder necesarios". (FREIXES SANJUÁN, Teresa. Los derechos sociales de los trabajadores en la Constitución. Madrid: Centro de Publicaciones del Ministerio de Trabajo y Seguridad Social, 1986. p. 41).
} 
monopólio do exercício da força para impor ao empregador regras para coibir práticas danosas ao trabalhador?

A conclusão é a de que não basta o reconhecimento da necessidade de proteção ao trabalhador sem cotejar as várias nuances que a relação de trabalho subordinado congrega, precisamente no local de trabalho. O ambiente de trabalho traduz uma dinâmica de poder e, na medida em que o Estado intervém, a estrutura da relação de trabalho subordinado sofre os impactos da imprescindibilidade de adequação aos propósitos perseguidos pela sociedade civil e contemplados na ordem constitucional.

Para atingir esse propósito, a atuação estatal na forma de fiscalização do trabalho, no Brasil, constitui indispensável instrumento de prevenção e contenção de irregularidades no âmbito da relação de trabalho subordinado.

Vale ponderar que a Organização Internacional de Trabalho (OIT) adota a denominação "inspeção" ao invés de "fiscalização". Inspeção vem de inspectionem, que significa olhar dentro, examinar. ${ }^{332}$ Por essa razão, "inspecionar" atrela-se à ideia de aproximação do objeto analisado. Renato Bignami enfatiza a importância da visita ao local de trabalho, "onde o inspetor pode, por meio dos seus sentidos, verificar se a norma está sendo cumprida" [grifo nosso].$^{333} \mathrm{O}$ inspetor, portanto, é observador, mas se torna parte sujeito - ativa na relação de trabalho subordinado, pois participa do processo de compreensão da realidade do trabalho a partir do seu referencial.

No Brasil, a denominação "inspetor do trabalho" foi alterada para "fiscal do trabalho" por força da Lei n. 6.986, de 13 de abril de 1982. Renato Bignami aponta duas razões para a mudança. A primeira seria a conotação extremamente policial da denominação inspetor em plena ditadura militar. $\mathrm{O}$ outro motivo seria a intenção do governo em atribuir ao agente público da Inspeção do Trabalho função de natureza arrecadadora, razão pela qual "fiscal" seria o termo apropriado. ${ }^{334}$

\footnotetext{
${ }^{332}$ BUENO, Francisco da Silveira. Grande dicionário etimológico-prosódico da língua portuguesa. São Paulo: Saraiva, 1968. v. 4, p. 1946.

${ }^{333}$ BIGNAMI, Renato. op. cit., p. 34.

${ }^{334}$ Id. Ibid., p. 35. Etimologicamente, a palavra "fisco está intimamente ligada à ideia de um conjunto de órgãos responsáveis pela arrecadação ou a fiscalização de tributos”. (Id., loc. cit.).
} 


\subsection{Convenção n. 81 da Organização Internacional do Trabalho}

A inspeção dos locais de trabalho é prioridade da OIT desde a sua fundação em 1919, com o Tratado de Versalhes. No mesmo ano de sua fundação, em sua primeira Conferência Internacional de Trabalho, foi adotada a Recomendação n. 5, que versa precisamente sobre inspeção do trabalho. O foco estava centrado nos serviços de saúde do trabalhador e a preocupação da OIT era incentivar os Estados-membros a instituírem não apenas um eficiente sistema de inspeção de fábricas, mas, além disso, um sistema de serviço público especialmente encarregado de salvaguardar a saúde dos trabalhadores e que mantivesse contato com a OIT. ${ }^{335}$ Em 29 de outubro de 1923 , em sessão da $5^{\text {a }}$ Conferência Internacional de Trabalho, foi aprovada a Recomendação n. 20, sobre os princípios gerais da organização dos sistemas de inspeção para assegurar o cumprimento das normas de proteção aos trabalhadores. Em suas considerações, a Recomendação pontua a importância indubitável do sistema de inspeção como um dos meios mais efetivos para garantir a observância das convenções da OIT e outros compromissos derivados da legislação de proteção ao trabalho. ${ }^{336}$ Essa Recomendação, em seu item 13, já alerta para a complexidade dos processos de produção industrial, o que implica a necessidade de um quadro de inspetores do trabalho com alto nível de treinamento técnico, com bom grau de educação e, capazes de conquistar a confiança de todas as partes envolvidas na relação de trabalho subordinado. No item 14, a OIT expõe sua preocupação em manter a integridade do sistema de inspeção do trabalho contra as influências externas, recomendando que o quadro de inspetores deve permanecer imune às mudanças de governo, que seja vedada a inspeção em estabelecimentos de interesse do inspetor e que sejam garantidos status e um nível de remuneração que proporcione liberdade frente a quaisquer influências externas contrárias aos objetivos da inspeção do trabalho. ${ }^{337}$

A partir desses marcos, a relevância do tema mantém-se uma constante, particularmente com a adoção da Convenção n. 81 da OIT sobre Inspeção do Trabalho na Indústria e no Comércio e a Convenção n. 129 sobre Inspeção do Trabalho na Agricultura.

\footnotetext{
${ }^{335}$ ORGANIZAÇÃO INTERNACIONAL DO TRABALHO. Resolução n. 5. Disponível em: $<$ http://www.ilo.org/ilolex/english/recdisp1.htm>. Acesso em: 05 ago. 2010.

${ }^{336}$ Id. Resolução n. 20, de 29 de outubro de 1923. Disponível em: <http://www.ilo.org/ilolex/cgilex/convde.pl?R020>. Acesso em: 05 ago. 2010.

${ }^{337}$ Id. Ibid.
} 
A Convenção n. 81 da OIT inclui-se entre o rol das mais ratificadas pelos Estadosmembros. Até julho de 2010, 141 (cento e quarenta e um) Estados-membros haviam ratificado a convenção. ${ }^{338}$ Adotadas pelo Brasil, o Congresso Nacional Brasileiro, por meio do Decreto Legislativo n. 24 de 29 de maio de 1956, aprovou as Convenções do Trabalho de números $11,12,14,19,26,29,81,88,89,95,96,99,100$ e 101, concluídas em sessões da Conferência Geral da Organização Internacional do Trabalho realizadas no período de 1946 a $1952 .{ }^{339}$ A promulgação ocorreu com o Decreto n. 41.721, de 25 de junho de 1957, publicado em 28 de junho de 1957. Em 15 de março de 1965, expediu-se o Decreto n. 55.841, em que foi aprovado o Regulamento de Inspeção do Trabalho.

É certo que as normas elaboradas pela OIT são marcadas pelo caráter avançado, de maneira que não se coadunam com as propostas e os interesses defendidos por regimes de cunho autoritário. Não foi diferente no caso brasileiro e, em 5 de abril de 1971, o governo brasileiro denunciou a Convenção n. 81, argumentando a inviabilidade de compor um quadro de inspetores do trabalho com estabilidade de emprego e independência frente a qualquer mudança de governo ou influência externa indevida, e de reembolsar as despesas eventualmente efetuadas pelos inspetores do trabalho no exercício da função. A denúncia tornou-se pública com o Decreto n. 68.796, de 23 de junho de 1971, cujo teor limitava a vigência da Convenção n. 81 da OIT até 05 de abril de 1972. ${ }^{340}$ Renato Bignami narra que, durante o período de denúncia da convenção, as funções executadas pelos inspetores de trabalho foram desvirtuadas, citando relatos de "inspetores que teriam sido utilizados pelo aparelho de informação do regime de exceção para colher informações sobre trabalhadores e sindicalistas, sempre em nome da doutrina da segurança nacional". ${ }^{341}$ Já no contexto do processo de redemocratização brasileira, o Decreto n. 95.461, de 11 de dezembro de 1987, revigorou em sua plenitude o Decreto $\mathrm{n}^{\circ} 41.721$, de 25 de junho de 1957, o qual promulgou a Convenção n. 81 da OIT.

Assim como o Brasil inseriu a Convenção n. 81 em seu ordenamento jurídico, quase todos os países no mundo têm alguma forma de inspeção do trabalho que abrange a maioria ou todos os setores que mantêm trabalho subordinado. A Convenção n. 81

\footnotetext{
${ }^{338}$ ILOLEX. Database of International Labour Standards. Disponível em: <http://www.ilo.org/ilolex/english/newratframeE.htm>. Acesso em: 05 ago. 2010.

${ }^{339}$ BRASIL. Decreto Legislativo n. 24, de 29 de maio de 1956. Disponível em: <http://www6.senado.gov.br/legislacao/ListaPublicacoes.action?id=110983>. Acesso em: 05 ago. 2010.

${ }^{340}$ MANNRICH, Nelson. Inspeção do trabalho. São Paulo: LTr, 1991. p. 43.

${ }^{341}$ BIGNAMI, Renato. op. cit., p. 34.
} 
sobrevive ao teste do tempo, "mas com os desafios de um veloz e mutável mundo do trabalho e os inspetores, mais que nunca, precisam de um substrato operacional e político atualizado, a fim de manter efetivo o sistema de inspeção, além de serem bem treinados para o que é uma função com grau de exigência cada vez maior, todavia importante". ${ }^{342}$

Destaca-se do conteúdo da Convenção n. 81 "a obrigação de manter o Sistema de Inspeção do Trabalho, constituído por servidores públicos, em número suficiente, com garantia de emprego e independentes, recrutados por suas qualificações e adequadamente treinados, para inspecionar a indústria e o comércio, com as funções principais de: a) garantir o cumprimento dos dispositivos legais referentes às condições de trabalho e proteção dos trabalhadores; b) fornecer informação técnica e orientar empregadores e trabalhadores; c) dar conhecimento à autoridade competente das deficiências e abusos não cobertos pela legislação". ${ }^{343}$

Para realizar suas atribuições, a Inspeção do Trabalho, nos termos da Convenção n. 81 da OIT, deve contar com a colaboração de especialistas e técnicos em saúde e segurança do trabalhador, para tornar possível a investigação dos processos materiais e métodos de trabalho e seus efeitos sobre a vida e saúde dos trabalhadores. ${ }^{344}$

Ainda não ratificada pelo Brasil, outra Convenção com conteúdo direcionado à inspeção do trabalho é a de n. 129, que trata da inspeção do trabalho na agricultura e faz parte do rol de convenções prioritárias.

\subsection{Breves considerações sobre a fiscalização do trabalho no Brasil}

Nelson Mannrich relata que "acredita-se que a primeira referência legal à Inspeção do Trabalho no Brasil tenha sido feita pelo Decreto n. 1.313, de 17.01.1891", sendo que tal diploma legal jamais foi aplicado. ${ }^{345}$ Porém, vale comentar que o referido decreto instituía, em seu artigo $1^{\circ}$, a fiscalização permanente de todos os estabelecimentos fabris em que trabalhassem menores. De acordo com esse mesmo dispositivo, a execução dessa função

\footnotetext{
${ }^{342}$ ALBRACHT, G. et al. Integrated labour inspection: training system (ILITS). Geneva: International Labour Office, 2006. p. 6.

${ }^{343}$ BRASIL. MINISTÉRIO DO TRABALHO E EMPREGO. Convenção da OIT. Brasília: MTE-SIT, 2002. p. 57-58.

${ }^{344}$ Id., loc. cit.

${ }^{345}$ MANNRICH, Nelson. op. cit., p. 41.
} 
ficaria a cargo de um inspetor geral, subordinado ao Ministro do Interior. No artigo $2^{\circ}$, do mencionado decreto, estabelecia-se a idade mínima para o trabalho em atividades fabris:

Art. $2^{\circ}$ Não serão admittidas ao trabalho effectivo nas fabricas crianças de um e outro sexo menores de 12 annos, salvo, a titulo de aprendizado, nas fabricas de tecidos as que se acharem comprehendidas entre aquella idade e a de oito annos completos. ${ }^{346}$

Porém, a vigência do Decreto n. 1.313, de 17.01.1891 restou limitada à Capital Federal, pois somente com a emenda constitucional de 1926 foi atribuído ao Congresso Nacional, em caráter privativo, legislar sobre trabalho, nos termos do artigo $34 .^{347}$

Com a ascensão de Getúlio Vargas ao poder, é criado o Ministério do Trabalho, Indústria e Comércio, pelo Decreto n. 19.433, de 26 de novembro de 1930. Em 04 de fevereiro de 1931, veio o Decreto n. 19.667 que organiza a estrutura do então denominado Ministério do Trabalho, Indústria e Comércio.

Com o Decreto n. 21.690, de 01 de agosto de 1932, foram criadas as Inspetorias Regionais nos Estados da Federação, mas, somente em 06 de maio de 1940, por meio do Decreto-Lei n. 2.168, essas foram transformadas em Delegacias Regionais do Trabalho e criou-se, por conseguinte, a função de Delegado Regional do Ministério do Trabalho, Indústria e Comércio.

A política de Getúlio Vargas deu sequência à adoção de medidas de proteção ao trabalho, corolária da sua vertente corporativista. Em 01 de maio de 1943, Getúlio Vargas expede o Decreto-Lei $n^{\circ}$ 5.452, dando origem à Consolidação das Leis do Trabalho - CLT. No texto normativo consolidado, a disciplina da Inspeção do Trabalho é tratada no Título VII - "Processo de Multas Administrativas". Faltava a regulamentação da carreira de inspetor do trabalho, que ocorreu com a edição da Lei n ${ }^{\circ}$ 6.479, de 09.04.44.

Mas o fator decisivo para a Inspeção do Trabalho no Brasil foi especialmente a ratificação da Convenção n. 81 da OIT, conforme se discutiu acima. ${ }^{348}$ Somente mais

\footnotetext{
${ }^{346}$ BRASIL. Decreto n. 1.313, de 17 de janeiro de 1891. Disponível em: <http://www6.senado.gov.br/legislacao/ListaPublicacoes.action?id=64469>. Acesso em: 06 ago. 2010.

${ }^{347}$ Id. Constituição da República dos Estados Unidos do Brasil, de 24 de fevereiro de 1891 com emendas de 1926. Disponível em: $<$ http://www.senado.gov.br/legislacao/BasesHist/asp/detalheDocumento.asp? codBase=2\&codDocumento= $873 \& s g B a s e=$ CONS\&q=CONSTITUIÇÃO+DA+REPÚBLICA+DOS+ESTADOS+UNIDOS+DO+BRASI L>. Acesso em: 06 ago. 2010.

${ }^{348}$ MANNRICH, Nelson. op. cit., p. 42.
} 
tarde, como consequência da ratificação da Convenção n. 81 da OIT, foi expedido o Decreto n. 55.841, de 15 de março de 1965, que dispôs sobre o que se passou a denominar “Regulamento de Inspeção do Trabalho" (RIT).

A Constituição da República de 1988 atribuiu à União, no artigo 21, inciso XXIV, de forma inédita na história constitucional, a competência para organizar, manter e executar a inspeção do trabalho. A Lei n. 8.028, de 12 de abril de 1990, em seu artigo 19, inciso VII, alínea "a", insere na competência do então denominado Ministério do Trabalho e da Previdência Social a fiscalização do trabalho.

Em 2002, o Decreto n. 4.552, de 27 de dezembro, aprova o novo Regulamento de Inspeção do Trabalho (RIT), revogando o Decreto n. 55.851/65. O Regulamento de Inspeção do Trabalho (Decreto n. 4.552/2002) prevê as prerrogativas, as atribuições e os deveres dos Auditores-fiscais do Trabalho, no exercício de suas funções. Combinado com os dispositivos da CLT, constitui a disciplina da conduta a ser observada pelos Auditoresfiscais do Trabalho (AFTs). No artigo 18, do referido decreto, encontram-se as atribuições conferidas aos AFTs, dentre elas, verificar o cumprimento das disposições legais e regulamentares, inclusive as relacionadas à segurança e saúde no trabalho, no âmbito das relações de trabalho e emprego, e ministrar orientações e dar informações e conselhos técnicos aos trabalhadores e pessoas sujeitas à inspeção do trabalho, atendidos os critérios administrativos de oportunidade e conveniência. O artigo 628, caput, da CLT dispõe que "a toda verificação em que o Auditor-Fiscal do Trabalho concluir pela existência de violação de preceito legal deve corrresponder, sob pensa de responsabilidade administrativa, a lavratura de auto de infração". Dessa forma, o Auditor-Fiscal do Trabalho conta com a possibilidade de exercício de medidas coercitivas autoexecutáveis para estimular o cumprimento da norma trabalhista. Isso significa que o Estado, ao elevar os valores sociais do trabalho à condição de fundamento da ordem constitucional (art. $1^{\circ}, \mathrm{IV}$, da Constituição Federal de 1988), destaca o monopólio da força - imposição de sanção como recurso para o atingimento do fim almejado pelo Estado democrático, qual seja, a observância das diretrizes normativas de proteção ao trabalho. 


\subsection{O fundamento da fiscalização do trabalho no Brasil: a ordem pública}

Ao realizar a fiscalização do cumprimento das normas de proteção ao trabalho, o Estado propõe-se, pois, conferir às relações de trabalho subordinado o status de questão de ordem pública, legitimando assim a imposição de restrições aos indivíduos coletivamente organizados em sociedade. O significado de ordem pública, conforme explica Giuseppe Vergottini $^{349}$, pode assumir duas vertentes. A primeira, derivada do direito público, defende uma concepção objetiva e material, em que:

A Ordem pública é concebida ao mesmo tempo como uma circunstância de fato como um fim do ordenamento político e estatal e nesse sentido o encontramos na legislação administrativa, policial e penal como sinônimo de convivência ordenada, segura, pacífica e equilibrada, isto é, normal e conveniente aos princípios gerais de ordem desejados pelas opções de base que disciplinam a dinâmica de um ordenamento. ${ }^{350}$

Por essa razão, a regulamentação da ordem pública envolve medidas de tutela preventiva, contextual e sucessiva ou repressiva, e se traduz em um "sistema de normas que a têm como objeto e que variam de ordenamento para ordenamento, cada um dando "uma disciplina própria (ampla ou restrita) das hipóteses de intervenção normativa e de administração direta tendentes a salvaguardar a Ordem pública". 351

Em outro sentido, a ordem pública é compreendida como limite ao exercício da autonomia contratual. Vergottini explicita que:

No direito privado, portanto, todas as vezes que a Ordem pública é evocada como limite ao exercício de direitos, ela se apresenta como noção residual que é difícil de definir de forma precisa: trata-se, na verdade, de um limite que atua quando não existem limites específicos e que tende a coincidir com a exigência, por via integrativa, do núcleo de princípios que caracterizam a constituição do Estado, mas que por vezes coincide com a exigência também de um núcleo de valores e critérios extrajurídicos que fogem a uma possível predeterminação objetiva. ${ }^{352}$

\footnotetext{
${ }^{349}$ BOBBIO, Norberto et al. Dicionário de política. 7. ed. Trad. Carmen C. Varriale et al. Brasília: Ed. da Universidade de Brasília, 1995. v. 2, p. 851.

${ }^{350}$ Id., loc. cit.

${ }^{351}$ Id., loc. cit.

${ }^{352}$ Id., loc. cit.
} 
O que a noção de ordem pública comporta em si é a complexidade do quadro da sociedade a que se refere. Como explica Alvaro Lazzarini, "a ordem pública é mais fácil de ser sentida do que definida" ${ }^{\text {353 }}$.O problema, portanto, repousa na impossibilidade de conferir à concepção de ordem pública a exatidão perseguida pela razão. Na medida em que congrega as várias esferas do agir humano, não possui contornos precisos e o seu amplo alcance inviabiliza a redução da complexidade para fins de análise e compreensão, o que contraria o modelo de certeza do positivismo.

"Ordem pública" aparece na Declaração Universal dos Direitos Humanos, no seu n. 2 do artigo $29 .^{\circ}$, nos seguintes termos:

No exercício destes direitos e no gozo destas liberdades ninguém está sujeito senão às limitações estabelecidas pela lei com vista exclusivamente a promover o reconhecimento e o respeito dos direitos e liberdades dos outros e a fim de satisfazer as justas exigências da moral, da ordem pública e do bem-estar numa sociedade democrática.

A ideia de ordem pública evoca, então, um sistema de normas com vistas à garantia da segurança e da vida em sociedade. Ou seja, "ordem pública" vem de encontro com a proposta decantada pelos contratualistas, os quais, resguardadas as diferenças teóricas, concebiam a sociedade organizada como resultado de um cálculo interesseiro dos indivíduos.

No curso da evolução do pensamento jurídico, o positivismo jurídico aparece, pois, como fruto de um processo iniciado com as teorias contratualistas, isto é, constitui mais um resultado do "cálculo interesseiro dos indivíduos", fundado na crença da razão humana, mas que, contrário ao jusnaturalismo, não admite imprecisões que comprometam "a certeza e a segurança jurídicas".

O que se mostra ao longo do tempo, porém, é que o Direito, como modelo de disciplina de condutas, não se reduz a descrever o "deve-ser", a partir de uma relação cartesiana sujeito-objeto. Da noção de Direito infere-se a ideia de um processo dinâmico de relações humanas interligadas, sobre o qual não se opera inexoravelmente a relação de causa-efeito. É circular e constante, como acontece com as relações de trabalho subordinado. Exige-se, assim, um processo contínuo de construção de sentido, amparada

\footnotetext{
${ }^{353}$ LAZZARINI, Alvaro. Estudos de direito administrativo. 2. ed. São Paulo: Ed. Revista dos Tribunais, 1999. p. 202.
} 
pela ideia de ordem pública, pressuposta como fundamento da sociedade civil. A ordem pública, enfim, enseja uma premissa maior, uma tese, a partir da qual os demais desdobramentos serão possivelmente elaborados: por ordem pública entende-se um quadro de estabilidade, ou ainda, de equilíbrio entre os sistemas sociais. A partir disso, o conteúdo da ordem pública será extraído do cenário traçado por cada ordenamento jurídico, o qual disporá sobre os fundamentos da constituição da sociedade. São esses fundamentos que orientarão o legislador e garantirão a ordem pública.

O trabalho é matéria de ordem pública, pois traduz um agir humano ${ }^{354}$, cujas repercussões na manutenção da segurança social e na vida humana foram historicamente verificadas. A Constituição da República Federativa do Brasil, promulgada em 1988, dispõe em seu artigo $1^{\circ}$ que um dos fundamentos do Estado Democrático de Direito, então constituído, é a dignidade da pessoa humana. Portanto, a dignidade da pessoa humana é fundamental para a instituição do Estado Democrático "destinado a assegurar o exercício dos direitos sociais e individuais, a liberdade, a segurança, o bem-estar, o desenvolvimento, a igualdade e a justiça como valores supremos de uma sociedade fraterna, pluralista e sem preconceitos, fundada na harmonia social e comprometida, na ordem interna e internacional, com a solução pacífica das controvérsias" ${ }^{\text {355 }}$. Dessa maneira, a dignidade compreende o conteúdo da ordem pública moldada pelo ordenamento jurídico brasileiro.

A expressão da dignidade perfaz-se na realização dos objetivos traçados na constituição do Estado Democrático de Direito, os quais estão relacionados no $\operatorname{artigo~} 3^{\circ}$ da Constituição da República de 1988:

Art. $3^{\circ}$ Constituem objetivos fundamentais da República Federativa do Brasil:

I - construir uma sociedade livre, justa e solidária;

II - garantir o desenvolvimento nacional;

III - erradicar a pobreza e a marginalização e reduzir as desigualdades sociais e regionais;

IV - promover o bem de todos, sem preconceitos de origem, raça, sexo, cor, idade e quaisquer outras formas de discriminação.

\footnotetext{
${ }^{354}$ Essa noção será melhor desenvolvida no Capítulo 4.

${ }^{355}$ BRASIL. Constituição da República Federativa do Brasil de 1988. Disponível em: <http://www.planalto.gov.br/ccivil_03/constituicao/constitui\%C3\%A7ao.htm>. Acesso em: 17 ago. 2010.
} 
Aqui interessa destacar que a promoção do bem de todos, a construção de uma sociedade livre, justa e solidária, a erradicação da pobreza e o desenvolvimento nacional dependem e convergem para um ambiente de equilíbrio de sistemas sociais, ou seja, de ordem pública. Nesse cenário, inserem-se as relações de trabalho subordinado e o sistema juslaboral é concebido com a função de disciplinar e estimular as condutas dos envolvidos nessas relações. Lembra-se que a sociedade capitalista se alicerçou e se alicerça no trabalho, de sorte que a manutenção da vida e da saúde do trabalhador passa a ser indispensáveis para a própria conservação do sistema. Foi o que motivou a Lei de Peel, ainda que sem resultados exitosos.

O cumprimento da legislação trabalhista, portanto, visa a um objetivo que extrapola o âmbito das partes imediatamente identificáveis na relação de trabalho subordinado: a adequação da conduta às normas juslaborais culminam na manutenção da ordem pública, que é - reforça-se - pressuposto para o equilíbrio das forças sociais em constante conflito. Por isso, o Auditor-Fiscal do Trabalho, quando visa ao cumprimento das normas de proteção ao trabalho, investiga a presença dos parâmetros normativos que garantam a dignidade do trabalhador, a fim de manter a ordem pública.

Conforme frisa a OIT, "a fiscalização não deve ser entendida como repressão sistemática: seu objetivo não é apanhar alguém em falta, mas fazer cumprir”. Ou seja, "a fiscalização não é um fim em si mesmo; é um meio de a inspeção se desincumbir de sua primeira e principal função: fazer cumprir as disposições legais". 356

Na concepção da OIT, a exigência do cumprimento das disposições legais pela ação fiscal não deveria ser restringida à esfera das relações de trabalho subordinado (ou relações de emprego). Na Sessão da Conferência n. 82 da OIT, em 22.06.1995, foi adotado o Protocolo de 1995 à Convenção de Inspeção do Trabalho de 1947 (P81). Nesse Protocolo, enfatizou-se a ampliação do campo de ação da fiscalização do trabalho, sendo que, em seu preâmbulo, aponta para todos os riscos aos quais os trabalhadores de setores de serviços não-comerciais podem estar expostos, e a necessidade de que esse setor esteja sujeito a um mesmo sistema de inspeção do trabalho imparcial ou equivalente a esse, da mesma forma que previsto na Convenção de Inspeção do Trabalho de $1947^{357}$.

\footnotetext{
${ }^{356}$ ORGANIZAÇÃO INTERNACIONAL DO TRABALHO. Inspeção do trabalho: manual de educação do trabalhador, cit., p. 29.

${ }^{357}$ ILOLEX. Database of International Labour Standards. Disponível em: <http://www.ilo.org/ilolex/english/subjlst.htm>. Acesso em: 17 ago. 2010.
} 
Em seu artigo $2^{\circ}$, o Protocolo admite a possibilidade de ratificação com ressalvas, excluindo totalmente ou parcialmente algumas categorias, dentre elas, atividades essenciais à administração do governo federal ${ }^{358}$. Uma vez que no Brasil a fiscalização do trabalho se limita a atuar em situações em que esteja presente a figura do empregado (relação de trabalho celetista), o Brasil ainda não ratificou o referido Protocolo, sendo que apenas 11 (onze) países o ratificaram ${ }^{359}$.

Por fim, o papel da fiscalização do traballho, portanto, vincula-se à ideia de ordem pública material acima apresentada, de maneira que se passa a indagar qual(is) o(s) mecanismo(s) previsto(s) no sistema juslaboral a viabilizar essa forma de exercício do poder de polícia administrativa.

\section{A observação "in loco": a fiscalização do trabalho como instrumento imediato de promoção dos direitos fundamentais do trabalhador}

De maneira direta e imediata, a fiscalização do trabalho, realizada atualmente no Brasil por Auditores-Fiscais do Trabalho ${ }^{360}$, previne as práticas danosas à vida e à saúde do trabalhador, em princípio, a partir da orientação.

A Norma Regulamentadora n. 2, aprovada pela Portaria n. 3214, de 08 de junho de 1978, previu nos itens 2.1. e 2.6. que:

2.1 Todo estabelecimento novo, antes de iniciar suas atividades, deverá solicitar aprovação de suas instalações ao órgão regional do MTb.

$[\ldots]$

2.6 A inspeção prévia e a declaração de instalações, referidas nos itens 2.1 e 2.3 , constituem os elementos capazes de assegurar que o novo estabelecimento inicie suas atividades livre de riscos de acidentes e/ou de doenças do trabalho, razão pela qual o estabelecimento que não atender ao disposto naqueles itens fica sujeito ao impedimento de seu funcionamento, conforme estabelece o art. 160 da CLT, até que seja cumprida a exigência deste artigo. (Alteração dada pela Portaria n. ${ }^{\circ} 35$, de 28/12/83)

\footnotetext{
${ }^{358}$ ILOLEX. Database of International Labour Standards. Disponível em: $<$ http://www.ilo.org/ilolex/english/subjlst.htm>. Acesso em: 17 ago. 2010.

${ }^{359}$ Id. Database of International $\quad$ Labour $\quad$ Standards. Disponível em: <http://www.ilo.org/ilolex/english/newratframeE.htm>. Acesso em: 05 ago. 2010.

${ }^{360}$ V. Lei n. 10.593, de 6 de dezembro de 2002.
} 
De acordo com essas regras, impõe-se ao empregador a necessidade de submeter à inspeção o estabelecimento, antes que ele inicie suas atividades, com vistas a verificar a adequação do local às normas de proteção à saúde e à segurança do trabalhador. Ou seja, o legislador, amparado pelos preceitos constitucionais, reconhece que a exposição aos riscos de vida e saúde do empregado pode resultar em danos de difícil reparação e com grave comprometimento ao equilíbrio social. Isso porque, dado o paradigma econômico capitalista, o trabalho subordinado foi e é indispensável para a dinâmica da sociedade, ainda que se possa discutir até quando esse modelo de trabalho é essencial ou não para a manutenção do sistema econômico. Porém, mesmo que o modelo de relação de trabalho subordinado pareça ceder espaço para outras formas de relações de trabalho, em princípio, identifica-se o que Ricardo Antunes cunhou sob o termo "classe-que-vive-do-trabalho"361.

E, em face disso, não são raras as hipóteses de "transformação" de relações de trabalho subordinado em outras modalidades com o fim de desvirtuar a natureza do vínculo entre as partes e afastar as implicações legais do contrato de trabalho. É o que ocorre com a chamada "pejotização" ou "cooperativas fraudulentas". A "classe-que-vive-do-trabalho" acaba por assumir o papel imposto pela estrutura econômica. Outro exemplo são os chamados modelos de gestão de qualidade (como o International Organization for Standartization - ISO), em que ao trabalhador se atribui a responsabilidade por adaptar-se e corresponder às normas de gestão para alcançar a certificação de qualidade. Isso significa que o trabalhador passa a responder imediata e diretamente pelos resultados da empresa.

Os impactos desse cenário na vida do trabalhador não são desprezíveis e comprometem a sua higidez psíquico-biológica. Conforme já foi abordado, a passagem do trabalhador de Sísifo para Proteus não é automática e desencadeiam efeitos danosos, cujos

\footnotetext{
${ }^{361}$ Ricardo Antunes explica que a expressão "classe-que-vive-do-trabalho" visa conferir validade à noção de classe adotada pela teoria marxista. Ao contrário dos autores que propugnam o fim do conceito de classe, Ricardo Antunes pretende "dar contemporaneidade e amplitude ao ser social que trabalha, à classe trabalhadora hoje, apreender sua efetividade sua processualidade e concretude." Para ele, "uma noção ampliada da classe trabalhadora inclui, então, todos aqueles e aquelas que vendem sua força de trabalho em troca de salário, incorporando, além do proletariado industrial, dos assalariados do setor de serviços, também o proletariado rural, que vendu sua força de trabalho para o capital. Essa noção incorpora o proletariado precarizado, o subproletariado moderno, part time, o novo proletariado do Mc Donald's, os trabalhadores hifenizados de que falou Beynon, os trabalhadores terceirizados e precarizados das empresas liofilizadas de que falou Juan José Castillo, os trabalhadores assalariados da chamada "economia informal", que muitas vezes são indiretamente subordinados ao capital, além dos trabalhadores desempregados, expulsos do processo produtivo e do mercado de trabalho pela reestruturação do capital e que hipertrofiam o exército industrial de reserva, na fase de expansão do desemprego estrutural". (ANTUNES, Ricardo. op. cit., p. 101 e 103-104).
} 
sinais podem surgir após decorrido um longo prazo, quando a relação de trabalho já não existe mais.

A fiscalização do trabalho, portanto, ao proceder à observação da realidade laboral no local em que se desenvolve, permite vislumbrar riscos latentes e/ou iminentes de difícil ou impossível reparação. Exemplifica-se com o caso da perda de audição de um trabalhador exposto por vários anos a níveis de ruído superiores aos suportáveis pelo ouvido humano.

E nem sempre são agentes físicos, químicos e biológicos, os quais são objetiva e metricamente verificáveis, os causadores de danos à saúde e à segurança ao trabalhador e esse é o dilema que exige percuciência do observador-sujeito da realidade investigada. $\mathrm{O}$ maior desafio inicial é propor um questionamento acerca das limitações do modelo juslaboral existente e sua capacidade para atender à demanda da sociedade plural (múltiplos interesses) e complexa (processo dinâmico com vários sistemas).

Nesse item, a tônica repousa na ação da fiscalização do trabalho com base no modelo atual e sobre o mecanismo previsto em caso de descumprimento do preceito legal, esgotadas as iniciativas de orientação e expirado o prazo para regularização.

Como visto, a fiscalização do trabalho surge como um corolário das exigências por melhores condições de vida e se fundamenta no reconhecimento dos direitos sociais. E aqui nasce a maior dificuldade inicial para a plena configuração dos limites e da atuação da fiscalização: legitimar a ação estatal no seio das relações privadas, a fim de garantir direitos fundamentais. O problema ganha maior relevância quando se observa que os direitos fundamentais sociais são considerados como direitos à prestação ${ }^{362}$, ou seja, o destinatário seria o Estado, e não o particular. Então, caberia esclarecer qual a justificativa para a atuação da fiscalização do trabalho, que se dirige à verificação do cumprimento das

\footnotetext{
${ }^{362}$ Os direitos à prestação enquadram-se na segunda dimensão dos direitos humanos, ou seja, são os direitos sociais e econômicos. Ingo Wolfgang Sarlet explica que os direitos à prestação representam uma evolução do Estado, que deixa de ter apenas a função de intervir na esfera da liberdade pessoal dos indivíduos, para assumir a incumbência de "colocar à disposição os meios materiais e implementar condições fáticas que possibilitem o efetivo exercício das liberdades fundamentais". Isso significa que "os direitos fundamentais a prestações objetivam, em última análise, a garantia não apenas da liberdade-autonomia (liberdade perante o Estado), mas também da liberdade por intermédio do Estado, partindo da premissa de que o indivíduo, no que concerne à conquista e manutenção de sua liberdade, depende em muito de uma postura ativa dos poderes públicos". (SARLET, Ingo Wolfgang. A eficácia dos direitos fundamentais. 3. ed. Porto Alegre: Livr. do Advogado, 2003. p. 195).
} 
normas trabalhistas - dentre elas, direitos fundamentais sociais ${ }^{363}$ - pelo empregador. Além, disso, os direitos prestacionais são caracterizados pela sua natureza compensatória, isto é, por servirem ao propósito de compensar algum desnível existente entre os sujeitos envolvidos na relação e garantir, assim, a igualdade material.

Ademais, os direitos fundamentais sociais como direitos prestacionais estariam adstritos à reserva do possível, ou seja, dependem da viabilidade econômica em determinado momento. Ainda os direitos sociais fundamentais nascem da ideia da igualdade material e da solidariedade, cujos conceitos não são absoluta e definitivamente determinados, o que compromete a eficácia desses direitos, em decorrência da margem de subjetivismo no traçado de seus contornos.

São essas questões que se propõe a apresentar nesse item.

\subsection{Fiscalização do trabalho no Brasil: intervenção na esfera privada ou participação na construção do sentido da dignidade?}

Inicialmente, discute-se como a fiscalização do trabalho está inserida no sistema jurídico. A atividade fiscalizatória empreendida pelo Estado ampara-se juridicamente no exercício do poder de polícia administrativa. Para compreender a importância do poder de polícia, faz-se necessário recuperar a noção de ordem pública já abordada. Dada a impossibilidade de se definir peremptoriamente o que seja a ordem pública, é certo, porém, que ela se traduz em uma situação de legalidade e de moralidade normal, ou seja, ela existe onde não há desordem e atos de violência, "de que espécie for, contra pessoas, bens ou o próprio Estado" 364 .

\footnotetext{
363،Não se identificam plenamente os direitos trabalhistas e direitos humanos do trabalhador, porque os direitos trabalhistas são mais amplos, patrimoniais e extrapatrimoniais, de natureza diversificada, são individuais e coletivos, econômicos, disciplinares, expressando-se por meio de regras de organização e de comportamento. Os direitos humanos do trabalhador são mais importantes e são inerentes à pessoa do trabalhador. Nem todos os direitos do trabalhador são indisponíveis, são irrenunciáveis, são instransacionáveis ou são de ordem pública. Essa distinção é necessária para evitar a generalização dos direitos do trabalhador em funão da tutela que lhes é dispensada; nem todos os direitos trabalhistas podem ter a mesma proteção que deve ser dispensada aos direitos humanos do trabalhador, estes, sim, merecedores da máxima tutela do Estado, transcendentes da relação de trabalho, identificáveis ou não com os direitos humanos civis e direitos de personalidade". (NASCIMENTO, Amauri Mascaro. Teoria geral de direito do trabalho. São Paulo: LTr, 1998. p. 286).

${ }^{364}$ LAZZARINI, Alvaro. op. cit., p. 202.
} 
A atividade estatal de fiscalização visa, portanto, à garantia da ordem pública e, para atingir essa finalidade, impõe aos particulares limitações ao exercício de direitos individuais. Mas como justificar a intervenção estatal, com imposição de restrição a direitos individuais, uma vez que, na trajetória da afirmação dos direitos humanos, os primeiros direitos reconhecidos referiam-se exatamente em evitar a ingerência do Estado na esfera das relações privadas? A análise, portanto, do papel fiscalizador do Estado também é resultado de uma evolução histórica em prol da proteção dos Direitos Humanos.

Celso Antônio Bandeira de Mello afirma que o poder, no direito público atual, aparece como instrumento a ser utilizado para o cumprimento do dever de atingir a finalidade legal ${ }^{365}$, para concluir que o "Direito Administrativo não é um Direito criado para subjugar os interesses ou os direitos dos cidadãos aos do Estado", e sim um "Direito que instrumenta, que arma o administrado, para defender-se contra os perigos do uso desatado do Poder" 366. Afirma-se, então, que o Direito Administrativo nasceu das Revoluções que acabaram com o regime absolutista da Idade Média ${ }^{367}$ e afirmaram os direitos individuais. Esse primeiro momento é marcado pelo Estado de Direito baseado em "princípios do liberalismo, em que a preocupação era a de assegurar ao indivíduo uma série de direitos subjetivos, dentre os quais a liberdade", de sorte que qualquer ameaça à liberdade somente seria admitida em caráter excepcional; "a regra era o livre exercício dos direitos individuais" 368 .

Porém, o curso dos acontecimentos históricos demonstrou que poder perpassa as várias esferas da sociedade e que as formas de abuso não são apenas praticadas pelo Estado em relação aos particulares.

Adam Smith já esclarecia como se desenvolvia a dinâmica interior das relações entre empregado e empregador na sociedade capitalista:

Os trabalhadores desejam conseguir mais, e os patrões dar o menos possível. (...) Não é, de qualquer maneira, difícil de prever qual das duas partes deverá, sob condições comuns, ter a vantagem na disputa, e forçar a outra a se adaptar aos seus termos ${ }^{369}$.

\footnotetext{
${ }^{365}$ MELLO, Celso Antônio Bandeira de. Curso de direito administrativo. 19. ed. São Paulo: Malheiros Ed., 2005. p. 36-37.

${ }^{366}$ Id. Ibid., p. 38-39.

${ }^{367}$ DI PIETRO, Maria Sylvia Zanella. Direito administrativo. 18. ed. São Paulo: Atlas, 2005. p. 24.

${ }^{368}$ Id. Ibid., p. 109-110.

${ }^{369}$ SMITH, Adam. An inquiry into the nature and causes of the wealth of nations, cit., p. 28.
} 
As estruturas de poder da relação de trabalho subordinado demonstram exatamente essa realidade e geraram, no início do desenvolvimento do capitalismo industrial, situações de instabilidade social e comprometimento ao direito à vida e à saúde. Ou seja, contrariouse o propósito liberal que alicerçou e justificou o surgimento do Estado de Direito, com base na ideia do contrato social. Aceitou-se a "descartabilidade do trabalho humano", conforme os interesses econômicos assim impusessem como medida mais eficiente. Significativa é a ponderação que faz Adam Smith:

O dono da terra, o fazendeiro, o industrial, o mercador, embora não empreguem um simples empregado, poderiam geralmente viver um ano ou dois com as reservas que conseguiram acumular. Muitos trabalhadores não poderiam subsistir uma semana, poucos poderiam subsistir um mês, e muito poucos um ano sem trabalho. A longo prazo, o trabalhador pode ser tão necessário ao seu patrão como o seu patrão para ele; mas a necessidade não é tão imediata. ${ }^{370}$

As decantadas liberdade e igualdade, que justificaram o ideal do contrato social e a adoção do sistema econômico-jurídico e social, não se faziam presente na realidade das relações entre os indivíduos, destacadamente nas de trabalho. O quadro de contradição levou à revisão dos limites de atuação do Estado de Direito e seu papel na sociedade constituída. Nesse segundo momento, destaca Maria Sylvia Zanella Di Pietro que o Estado liberal começa a transformar-se em Estado intervencionista, de maneira que não visa somente à segurança, mas estende a sua atuação à ordem econômica e social ${ }^{371}$. Esse momento coincide com a afirmação dos direitos humanos sociais ou também designados direitos humanos de segunda dimensão ${ }^{372}$.

Antes de iniciar o século XX, Maria Sylvia Zanella Di Pietro ensina que se passou a falar em uma polícia geral relativa à segurança pública, e em polícias especiais, essas últimas com atuação em variados setores da atividade dos particulares ${ }^{373}$. Dessa maneira, ao poder estatal foi admitido "limitar o exercício dos direitos individuais em benefício do

\footnotetext{
${ }^{370}$ SMITH, Adam. An inquiry into the nature and causes of the wealth of nations, cit., p. 28.

${ }^{371}$ DI PIETRO, Maria Sylvia Zanella. op. cit., p. 110.

${ }^{372}$ Adota-se aqui "dimensão" em preferência ao termo "geração", seguindo entendimento de Paulo Bonavides, "caso este último venha a induzir apenas sucessão cronológica e, portanto, suposta caducidade dos direitos das gerações antecedentes, o que não é verdade. Ao contrário, os direitos da primeira geração, direitos individuais, os da segunda, direitos sociais, e os da terceira, direitos ao desenvolvimento, ao meio ambiente, à paz e à fraternidade, permanecem eficazes, são infra-estruturais, formam a pirâmide cujo ápice é o direito à democracia" (BONAVIDES, Paulo. op. cit., p. 572).

${ }^{373}$ DI PIETRO, Maria Sylvia Zanella. op. cit., p. 110.
} 
interesse público",374. Na medida em que não mais restringe à segurança, a atuação do poder estatal abrangeu relações entre particulares e, como consequência, a noção de ordem pública passou a compreender a ordem econômica e social ${ }^{375}$. A fiscalização do trabalho é exemplo da ampliação semântica de ordem pública.

Do ponto de vista enciclopédico, Nelson Mannrich explica que, "apesar de se utilizar de alguns princípios que informam o Direito Administrativo e a Inspeção do Trabalho consistir num instituto formado de órgãos estatais, não o integra, e, sim, o Direito do Trabalho. Localiza-se no chamado Direito Público do Trabalho"376.

A importância da fiscalização do trabalho é reconhecida pela OIT, conforme já foi analisado no item anterior. A OIT reconhece três sistemas de inspeção do trabalho: a) sistema único, aplicável a todos os setores de atividade econômica; b) sistema de inspeção definido por competência quanto ao objeto de controle; c) sistema adotado pelos então países do bloco socialista, com forte presença dos sindicatos no controle do trabalho ${ }^{377}$. A opção do legislador brasileiro pelo sistema único não afasta, contudo, a presença da atuação sindical ou dos trabalhadores. A denúncia de irregularidades na relação de trabalho, formulada perante o Ministério do Trabalho e Emprego, dá início ao procedimento fiscalizatório e aproxima a ação estatal das necessidades da coletividade. A eficácia, então, da fiscalização do trabalho depende do exercício da cidadania. Porém, para tanto, é indispensável a participação ativa de trabalhadores e de representantes conscientes não somente dos direitos protegidos pelo ordenamento jurídico, mas também da responsabilidade que assumem na construção do sentido da dignidade do trabalhador no dia-a-dia na medida que fazem parte das relações de trabalho subordinado.

A prevenção dos danos é o mote do exercício do poder de polícia administrativa. Mas nem sempre o quadro admite medidas preventivas, quando já restaram perpetradas as infrações à legislação do trabalho. Nesse caso, cabe conter as práticas danosas aos trabalhadores, o que, na esfera da fiscalização do trabalho no Brasil, dá-se por meio da adoção de medidas coercitivas indiretas e, excepcionalmente, diretas.

\footnotetext{
${ }^{374}$ DI PIETRO, Maria Sylvia Zanella. op. cit., p. 111.

${ }^{375}$ Id. Ibid., p. 110.

${ }^{376}$ MANNRICH, Nelson. op. cit., p. 60.

${ }^{377}$ ORGANIZAÇÃO INTERNACIONAL DO TRABALHO. L'inspection $d u$ travail: manuel d'éducation ouvrière. Genéve: Bureau International du Travail, 1986. p. 25-32.
} 
O Decreto n. 4.552, de 27 de dezembro de 2002, ao definir as atribuições dos Auditores-Fiscais do Trabalho, estabelece em seu artigo 18 os seguintes itens:

$[\ldots]$

VIII - inspecionar os locais de trabalho, o funcionamento de máquinas e a utilização de equipamentos e instalações;

IX - averiguar e analisar situações com risco potencial de gerar doenças ocupacionais e acidentes do trabalho, determinando as medidas preventivas necessárias;

$\mathrm{X}$-notificar as pessoas sujeitas à inspeção do trabalho para o cumprimento de obrigações ou a correção de irregularidades e adoção de medidas que eliminem os riscos para a saúde e segurança dos trabalhadores, nas instalações ou métodos de trabalho;

XI - quando constatado grave e iminente risco para a saúde ou segurança dos trabalhadores, expedir a notificação a que se refere o inciso $X$ deste artigo, determinando a adoção de medidas de imediata aplicação;

XII - coletar materiais e substâncias nos locais de trabalho para fins de análise, bem como apreender equipamentos e outros itens relacionados com a segurança e saúde no trabalho, lavrando o respectivo termo de apreensão;

XIII - propor a interdição de estabelecimento, setor de serviço, máquina ou equipamento, ou o embargo de obra, total ou parcial, quando constatar situação de grave e iminente risco à saúde ou à integridade física do trabalhador, por meio de emissão de laudo técnico que indique a situação de risco verificada e especifique as medidas corretivas que deverão ser adotadas pelas pessoas sujeitas à inspeção do trabalho, comunicando o fato de imediato à autoridade competente;

$\mathrm{XIV}$ - analisar e investigar as causas dos acidentes do trabalho e das doenças ocupacionais, bem como as situações com potencial para gerar tais eventos; [...]

Dos incisos acima destacados, extrai-se que o poder de polícia conferido à fiscalização do trabalho permite averiguar situações com potencial risco à saúde ou à integridade física do trabalho, derivadas das instalações ou dos métodos de trabalho. Essa assertiva, depreendida da interpretação do Decreto n. 4.552/2002, que aprovou o Regulamento da Inspeção do Trabalho, significa que o(a) Auditor(a)-Fiscal do Trabalho assume no curso da ação fiscal o papel de observador da realidade das condições de trabalho, mas, na medida em que também deve analisar riscos potenciais decorrentes das instalações e também dos métodos de trabalho, ele(a) deixa de ser mero(a) observador(a) para se tornar partícipe (sujeito) da construção de sentido da dignidade do trabalhador, ou seja, influencia na qualidade, no valor a ser atribuído à relação de trabalho. 
Enfim, o(a) Auditor(a)-Fiscal do Trabalho, ao ingressar no estabelecimento, também passa a ser sujeito e a participar da dinâmica da relação de trabalho subordinado. Essa revela, então, suas formas amplas: é mais que uma relação contratual de trabalho, pois contém a importância da matéria de ordem pública. A presença do(a) Auditor(a)-Fiscal do Trabalho passa a ser imprescindível para acentuar o caráter complexo da relação de trabalho subordinado, nem sempre plenamente perceptível no cotidiano da prestação de serviço, ainda mais sob o discurso atual das gestões participativas.

\subsection{Conceitos indeterminados}

A formatação dos contornos da dignidade do trabalhador, do qual o(a) Auditor(a)Fiscal do Trabalho participa, relaciona-se com a dificuldade de o sistema jurídico operar com a indeterminação dos conceitos. José Renato Nalini destaca que existem valores que substituíram velhas estruturas, mas questiona: "fruem eles de um consenso mínimo para ensejar o compromisso de fazê-los valer?" 378 Analise-se o artigo 468, caput, da Consolidação das Leis do Trabalho. Esse artigo trata da impossibilidade de alteração contratual que expresse prejuízo ao trabalhador:

Art. 468 - Nos contratos individuais de trabalho só é lícita a alteração das respectivas condições por mútuo consentimento, e, ainda assim, desde que não resultem, direta ou indiretamente, prejuízos ao empregado, sob pena de nulidade da cláusula infringente desta garantia

O entrave para o intérprete é a definição dos contornos do que vem a ser "prejuízo direto ou indireto" para o trabalhador. O "prejuízo" ao trabalhador nem sempre pode ser metrificamente analisado, porque pode depender de condições peculiares da relação de trabalho. A abordagem, então, não se dirige à descrição do que vem a ser "prejuízo" para o trabalhador, mas o legislador se ocupou dos limites do jus variandi e, portanto, concentrou a discussão em torno do exercício do poder nas relações de trabalho. Gustavo Filipe Barbosa Garcia aponta dois tipos de jus variandi: ordinário e extraordinário ${ }^{379}$. O jus variandi ordinário é o poder atribuído ao empregador para alterar unilateralmente as

\footnotetext{
${ }^{378}$ NALINI, José Renato. Prefácio - A transversalidade dos direitos humanos. IN: NALINI, José Renato \& CARLINI, Angélica. Direitos humanos e formação jurídica. Rio de Janeiro: Forense, 2010. p. X.

${ }^{379}$ GARCIA, Gustavo Filipe Barbosa. Curso de direito do trabalho. São Paulo: Ed. Método, 2007. p. 290.
} 
cláusulas do contrato de trabalho, desde que a alteração não descaracterize consideravelmente as condições iniciais da contratação e não gere prejuízos ao trabalhador. Por outro lado, o exercício do jus variandi extraordinário - também decorrência do poder diretivo do empregador - promove alterações relevantes, dadas determinadas condições. Em razão do grau de importância das alterações promovidas pelo jus variandi extraordinário, esse somente pode ser empregado nas hipóteses previamente definidas pela legislação trabalhista vigente, como no caso previsto no artigo 459, caput, da CLT, que trata da possibilidade de transferência do trabalhador de local de trabalho que não resulte em alteração de município.

As hipóteses de exercício do jus variandi contempladas pelo legislador, embora gerem discussões nos tribunais ${ }^{380}$, correspondem à função do sistema jurídico sob uma perspectiva positivista, em que o Direito é um sistema de regras preceituais ${ }^{381}$. Porém, quando se admite no sistema jurídico a possibilidade de alteração - ainda que de pouca relevância e sem prejuízo para o trabalhador -, motivada pelo jus variandi ordinário, passa a se exigir um esforço interpretativo para fixar os contornos do quem vem a constituir "prejuízo" para o trabalhador. Alice Monteiro de Barros denomina o jus variandi ordinário de "alteração voluntária unilateral" e admite essa possibilidade de alteração como "uma faculdade concedida ao empregador, com fundamento no poder diretivo de realizar modificações e variações na prestação de serviços conforme as circunstâncias, exigências ou perigos que surjam na realidade fática" ${ }^{382}$. Nota-se que, para a autora, a alteração voluntária unilateral é um instituto jurídico que não se confunde com o rebus sic stantibus, razão pela qual ele é tratado de maneira particular. Alice Monteiro de Barros traz exemplos do que viriam a ser os aspectos circunstanciais:

o empregador poderá trocar o maquinário utilizado pelo empregado, tendo em vista os avanços tecnológicos, instituir, em princípio, o uso de uniformes ou modificar aqueles já utilizados, modificar o tempo de duração das viagens, o horário de início e término da jornada, desde que dentro do mesmo turno e desde que a mudança não seja prejudicial ao empregado. $\mathrm{O}$ empregador poderá também efetuar modificações no espaço físico do estabelecimento ${ }^{383}$.

\footnotetext{
${ }^{380}$ V. Súmula 265 e 372 do Tribunal Superior do Trabalho, por exemplo.

${ }^{381}$ CASTRO, Carlos Roberto Siqueira. A constituição aberta e os direitos fundamentais: ensaios sobre o constitucionalismo pós-moderno e comunitário. Rio de Janeiro: Ed. Forense, 2003. p. 47

${ }^{382}$ BARROS, Alice Monteiro. Curso de direito do trabalho. 3. ed. São Paulo: LTr, 2007. p. 829.

${ }^{383}$ Id., loc. cit.
} 
Ao admitir aspectos circunstanciais ligados à atividade econômica do empregador, realiza-se uma abertura sistêmica, cujo principal parâmetro para definir a validade ou não da alteração contratual não é uma regra jurídica, mas o princípio de proteção ao trabalhador. Ou seja, as vicissitudes da ordem econômica podem comprometer a atividade do empregador. Embora esteja claro na legislação trabalhista que os riscos da atividade econômica são de responsabilidade exclusiva do empregador (artigo $2^{\circ}$, caput, da Consolidação das Leis do Trabalho), admite-se o exercício do poder diretivo para reorganizar o trabalho e, consequentemente, alterar as condições iniciais do contrato de trabalho, desde que não haja prejuízo ao trabalhador. O limite está, portanto, em um conceito indeterminado.

Por "conceitos jurídicos indeterminados" entendem-se "as expressões propositadamente vagas utilizadas pragmaticamente pelo legislador com a finalidade de propiciar o ajuste de certas normas a uma realidade cambiante ou ainda pouco conhecida" ${ }^{, 384}$. A previsão pelo legislador de conceitos jurídicos indeterminados permite ao intérprete adequar a legislação às condições sócio-econômicas, políticas e culturais extraídas do caso concreto $^{385}$.

As dificuldades decorrentes dos conceitos indeterminados verificam-se no âmbito das atribuições do(a) Auditor(a)-Fiscal do Trabalho no exercício do poder de polícia administrativa: o risco potencial decorrente de métodos de trabalho abrangeria a ideia de gestão organizacional? Grave e iminente risco seria aquele materialmente, objetivamente determinável, ou também se refere a eventuais danos na vida social do trabalhador, em razão de alterações contratuais, como banco de horas, transferências de local de trabalho, ou pressões psicológicas que venham a prejudicar o convívio familiar e a perspectiva de futuro do ser humano na sociedade?

No Acórdão n. 20090386919, prolatado pela $4^{\text {a }}$ Turma do Tribunal Regional do Trabalho da $2^{\mathrm{a}}$ Região, nos autos do processo TRT/SP n. 01773200603302007, figurou como recorrida a empresa Nestlé Brasil Ltda, condenada a pagar ao trabalhador Gilberto Marçola o valor arbitrado de $\mathrm{R} \$ 30.000,00$ (trinta mil reais), em razão de ter sido dispensado logo em seguida à sua transferência, com sua família, para outra localidade. $\mathrm{Na}$ ementa do acórdão, a relatora Ivani Contini Bramante destaca que tal procedimento

\footnotetext{
${ }^{384}$ FARIA, José Eduardo. Direito e economia na democratização brasileira. São Paulo: Malheiros Ed., 1993. p. 139.

${ }^{385}$ Id., loc. cit.
} 
adotado pela empregadora "ofende os princípios da dignidade da pessoa humana (art. $1^{\circ}$., III da CF/88), da boa-fé contratual (art. 422 do Código Civil) e da função social do contrato (art. 421 do Código Civil), cláusulas implícitas no contrato de trabalho)"3866.

Ulrich Beck, ao analisar a insegurança das relações de trabalho, traz o exemplo concreto da mãe que vive sozinha, tem de se adaptar ao mercado e enfrenta permanentemente:

a necessidade de trocar de emprego e organizar os horários de modo a timizar sua disponibilidade para ao mercado de trabalho e que também esteja disposta a se mudar constantemente, de uma semana para outra ou de um mês para outro, acaba se transformando em uma mãe desnaturada em razão das circunstâncias, já que o ritmo cronológico diferente do mercado de trabalho a obriga a negligenciar os filhos. ${ }^{387}$

Como conclui Ulrich Beck, "é possível dizer que essa oposição entre as demandas das relações, da paternidade, dos filhos, entra em uma contradição cada vez mais acentuada com as imposições de flexibilidade do mercado de trabalho" ${ }^{, 388}$. Os efeitos das relações de trabalho flexíveis extrapolam o campo contratual e atingem o conjunto da sociedade como um todo e as relações interpessoais.

Dessa forma, quando o(a) Auditor(a)-Fiscal do Trabalho analisa o prejuízo ao trabalhador e aplica medidas de coerção indireta (lavratura do auto de infração) com vistas a manter o cumprimento da legislação trabalhista, ele projeta a importância do sistema juslaboral para o ambiente social. É certo que a atividade fiscalizatória esbarrra nos conceitos indeterminados, que caracterizam o sistema jurídico dos direitos fundamentais e lhe conferem flexibilidade na aplicação da norma jurídica. Mas, quanto a essa questão, orienta-se, pois, pelo ensinamento de Nelson Mannrich, ao tratar da natureza jurídica da inspeção do trabalho:

Pelo fato de as normas trabalhistas, em geral, serem de "ordem pública", devido ao seu caráter repressivo e imperativo, deve-se ponderar que a sua aplicação não exclui a flexibilidade, graças ao princípio da norma mais favorável. Com efeito, cabe ao inspetor, através de amplos poderes discricionários colocados a sua disposição, tomar as medidas que julgar necessárias com a finalidade de atuação da legislação social, devendo,

\footnotetext{
${ }^{386}$ TRIBUNAL REGIONAL DO TRABALHO DA 2 ${ }^{\mathrm{a}}$ REGIÃO. Processo TRT/SP - 01773200603302007 RO - Ac. 4aT 20090386919 - Rel. Ivani Contini Bramante, publicado no DOE 29/05/2009. Disponível em: <http://www.trtsp.jus.br/. Acesso em: 01 out. 2010.

${ }^{387}$ BECK, Ulrich. Liberdade ou capitalismo: Ulrich Beck conversa com Johannes Willms. Trad. Luiz Antônio Oliveira de Araújo. São Paulo: Ed. UNESP, 2003. p. 169.

${ }^{388}$ Id., loc. cit.
} 
antes de tudo, prevenir as infrações e, na sua ocorrência, autuar o infrator. Para tanto, dentro de certos limites, deve afastar-se da rigidez da lei para melhor atingir a sua finalidade. É por essa razão que, na França, chega-se a afirmar que os Inspetores foram transformados em verdadeiros juízes em matéria social. ${ }^{389}$

Daí a importância de apreciar a atividade da fiscalização do trabalho com base em um parâmetro que extrapola os limites de uma concepção juspositivista-racional e alcança o conteúdo definido por dignidade do trabalhador. Ou seja, as medidas coercitivas impostas pela fiscalização do trabalho encontram fundamento nos direitos sociais fundamentais destinados à proteção do ser humano trabalhador.

\subsection{O desafio da eficácia horizontal dos direitos humanos nas relações de trabalho}

A ideia de direitos fundamentais encontra justificativa na necessidade de limitação de poder. Se originariamente o poder contra o qual se justificou a consagração dos direitos fundamentais foi o estatal, constatou-se que a dinâmica do poder na sociedade exige a ampliação da eficácia dos direitos fundamentais entre os particulares.

Resta pendente resposta para as observações de Norberto Bobbio, ao avaliar a natureza das normas de direitos sociais fundamentais:

Enquanto os direitos de liberdade nascem contra o superpoder do Estado e, portanto, com o objetivo de limitar o poder -, os direitos sociais exigem, para sua realização prática, ou seja, para a passagem da declaração puramente verbal à sua proteção efetiva, precisamente o contrário, isto é, a ampliação dos poderes do Estado. (...) na Constituição italiana, as normas que se referem a direitos sociais foram chamadas puramente de programáticas. Será que já nos perguntamos alguma vez que gênero de normas são essas que não ordenam, proíbem e permitem num futuro indefinido e sem prazo de carência claramente delimitado? E, sobretudo, já nos perguntamos alguma vez que gênero de direitos são esses que tais normas definem? Um direito cujo reconhecimento e cuja efetiva proteção são adiados sine die, além de confiados à vontade de sujeitos cuja obrigação de executar o 'programa' é apenas uma obrigação moral ou, no máximo, política, pode ainda ser chamado corretamente de "direito'?". 390

\footnotetext{
${ }^{389}$ MANNRICH, Nelson. op. cit., p. 68.

${ }^{390}$ BOBBIO, Norberto. A era dos direitos. Rio de Janeiro: Campus, 1992. p. 72.
} 
Aqui se expõe mais uma vez o dilema originado pela concepção de Direito calcada no paradigma científico-racional: dado que os direitos fundamentais têm contornos e referências diferenciados - complexidade social, instabilidade e não são plenamente redutíveis à metrificação -, são eles desprovidos de eficácia imediata ou mitiga-se a sua eficácia, remodelando-os para criar, assim, uma natureza normativa particular. E, então, fica a dúvida apontada por Bobbio: se sua eficácia repousa na vontade dos sujeitos, seria isso tecnicamente "direito"?

Daniel Sarmento lembra que os direitos fundamentais foram concebidos como direitos públicos subjetivos, oponíveis apenas em face do Estado, de maneira que:

no catecismo do constitucionalismo liberal, o locus exclusivo de regulamentação das relações privadas era o Código Civil, que tendo por pilares a propriedade e o contrato, buscava assegurar a segurança e a previsibilidade das regras do jogo para os sujeitos de direito nas suas relações recíprocas, a partir de uma perspectiva (falsa) de asséptica neutralidade diante dos conflitos distributivos. ${ }^{391}$

Porém, como pondera Marcelo Freire Sampaio Costa, o surgimento de entes privados - pessoas jurídicas ou naturais - detentoras de poder de autoridade antes exclusivo ao ente estatal, gerou relações de poder privado "semelhantes às relações especiais típicas do direito administrativo"392. Esse fato decorrente da complexidade das relações sociais exige a ampliação do alcance dos direitos fundamentais, não mais restrito na esfera vertical (indivíduo frente ao Estado).

Emblemático é o acórdão prolatado em sede de Recurso Extraordinário, relatado pelo Ministro Gilmar Mendes, em que se menciona e reconhece explicitamente a eficácia dos direitos fundamentais nas relações privadas:

EMENTA: SOCIEDADE CIVIL SEM FINS LUCRATIVOS. UNIÃO BRASILEIRA DE COMPOSITORES. EXCLUSÃO DE SÓCIO SEM GARANTIA DA AMPLA DEFESA E DO CONTRADITÓRIO. EFICÁCIA DOS DIREITOS FUNDAMENTAIS NAS RELAÇÕES PRIVADAS. RECURSO DESPROVIDO.

I. EFICÁCIA DOS DIREITOS FUNDAMENTAIS NAS RELAÇÕES PRIVADAS. As violações a direitos fundamentais não ocorrem somente no âmbito das relações entre o cidadão e o Estado, mas igualmente nas relações travadas entre pessoas físicas e jurídicas de direito privado. Assim, os direitos fundamentais assegurados pela Constituição vinculam

\footnotetext{
${ }^{391}$ SARMENTO, Daniel. op. cit., p. 30.

${ }^{392}$ COSTA, Marcelo Freire. Eficácia dos direitos fundamentais entre particulares: juízo de poderação no processo do trabalho. São Paulo: LTr, 2010. p. 65.
} 
diretamente não apenas os poderes públicos, estando direcionados também à proteção dos particulares em face dos poderes privados. II. $O S$ PRINCÍPIOS CONSTITUCIONAIS COMO LIMITES À AUTONOMIA PRIVADA DAS ASSOCIAÇÕES. A ordem jurídico-constitucional brasileira não conferiu a qualquer associação civil a possibilidade de agir à revelia dos princípios inscritos nas leis e, em especial, dos postulados que têm por fundamento direto o próprio texto da Constituição da República, notadamente em tema de proteção às liberdades e garantias fundamentais. O espaço de autonomia privada garantido pela Constituição às associações não está imune à incidência dos princípios constitucionais que asseguram o respeito aos direitos fundamentais de seus associados. A autonomia privada, que encontra claras limitações de ordem jurídica, não pode ser exercida em detrimento ou com desrespeito aos direitos e garantias de terceiros, especialmente aqueles positivados em sede constitucional, pois a autonomia da vontade não confere aos particulares, no domínio de sua incidência e atuação, o poder de transgredir ou de ignorar as restrições postas e definidas pela própria Constituição, cuja eficácia e força normativa também se impõem, aos particulares, no âmbito de suas relações privadas, em tema de liberdades fundamentais. III. SOCIEDADE CIVIL SEM FINS LUCRATIVOS. ENTIDADE QUE INTEGRA ESPAÇO PÚBLICO, AINDA QUE NÃOESTATAL. ATIVIDADE DE CARÁTER PÚBLICO. EXCLUSÃO DE SÓCIO SEM GARANTIA DO DEVIDO PROCESSO LEGAL.APLICAÇÃO DIRETA DOS DIREITOS FUNDAMENTAIS À AMPLA DEFESA E AO CONTRADITÓRIO. As associações privadas que exercem função predominante em determinado âmbito econômico e/ou social, mantendo seus associados em relações de dependência econômica e/ou social, integram o que se pode denominar de espaço público, ainda que não-estatal. A União Brasileira de Compositores - UBC, sociedade civil sem fins lucrativos, integra a estrutura do ECAD e, portanto, assume posição privilegiada para determinar a extensão do gozo e fruição dos direitos autorais de seus associados. A exclusão de sócio do quadro social da UBC, sem qualquer garantia de ampla defesa, do contraditório, ou do devido processo constitucional, onera consideravelmente o recorrido, o qual fica impossibilitado de perceber os direitos autorais relativos à execução de suas obras. A vedação das garantias constitucionais do devido processo legal acaba por restringir a própria liberdade de exercício profissional do sócio. O caráter público da atividade exercida pela sociedade e a dependência do vínculo associativo para o exercício profissional de seus sócios legitimam, no caso concreto, a aplicação direta dos direitos fundamentais concernentes ao devido processo legal, ao contraditório e à ampla defesa (art. $5^{\circ}$, LIV e LV, CF/88). IV. RECURSO EXTRAORDINÁRIO DESPROVIDO. ${ }^{393}$

\footnotetext{
${ }^{393}$ SUPREMO TRIBUNAL FEDERAL, $2^{\text {a }}$ Turma. RE n. 201819/RJ. Rel. Ministro Gilmar Mendes. Diário de Justiça, 27 out. 2006. p. 577. Disponível em: $<$ http://www.stf.jus.br/portal/diarioJustica/verDiarioProcesso.asp?numDj=207\&dataPublicacaoDj=27/10/2 006\&incidente $=1641534 \&$ codCapitulo $=5 \&$ numMateria $=35 \& \operatorname{codMateria}=3>$. Acesso em: 15 out. 2010 .
} 
Diante disso, a alegação de que os direitos fundamentais não podem ser invocados para limitar o exercício de poder na esfera privada não se sustenta, em face da dinâmica e da complexidade das relações de poder.

\subsection{Reserva do possível face à fiscalização do trabalho}

Outro argumento utilizado para condicionar a aplicação imediata dos direitos fundamentais é a viabilidade econômica, ou melhor, a denominada reserva do possível. O enfoque dado nessa concepção dos direitos fundamentais é considerá-los como direitos subjetivos ${ }^{394}$, cujos custos para sua efetivação não seriam reputados como óbices, e sim como meios $^{395}$. Na hipótese de não existirem recursos públicos suficientes, não há como garantir a eficácia do direito fundamental.

Observa-se aqui a ênfase na eficácia vertical dos direitos fundamentais e, em um primeiro momento, a preocupação com a eficiência em termos econômicos. Segundo adverte Flávio Galdino, "é fundamental que o Direito enquanto ciência possa ser um canal eficiente para as várias racionalidades sociais - da economia, da política, da sociologia... e também da própria racionalidade jurídica". E é importante considerar, como destaca o referido autor, a necessária convivência com as virtudes das outras normas sociais (econômicas, por exemplo) e com os seus discursos ${ }^{396}$.

Mas o risco que se apresenta, portanto, são as soluções sugeridas por esses outros discursos, alheios à racionalidade jurídica, aos problemas sociais. $\mathrm{O}$ discurso da reserva do possível, por exemplo, não prioriza a necessidade de avaliar o custo-benefício além do viés econômico. Flávio Galdino ressalta ainda "que a prevalência da racionalidade econômica pura traz consigo o risco da tirania do dinheiro",397.

Sendo assim, o paradigma econômico pode inspirar o sistema jurídico para tornar mais eficiente os mecanismos de garantia de ordem pública (base da organização do sistema jurídico). E o papel da economia nesse viés é oferecer instrumentos para aferição de eventuais impossibilidades reais para a aplicação de direitos fundamentais, com base na

\footnotetext{
${ }^{394} \mathrm{~V}$. GALDINO, Flávio. Introdução à teoria dos custos dos direitos: direitos não nascem em árvores. Rio de Janeiro: Lumen Juris, 2005. p. 143-146.

${ }^{395}$ Id. Ibid., p. 234.

${ }^{396}$ Id. Ibid., p. 253.

${ }^{397}$ Id. Ibid., p. 249.
} 
compreensão da escassez de recursos. A proposta, então, é reconhecer, por meio de normas jurídicas e de sua aplicação, a possibilidade de "agregar condições econômicas e considerações éticas (valores), maximizando a eficiência das instituições sem necessário prejuízo dos valores envolvidos" ${ }^{398}$.

$\mathrm{O}(\mathrm{A})$ Auditor(a)-Fiscal do Trabalho deve estar a par desses discursos para poder avaliar a realidade das relações privadas com vistas ao cumprimento da legislação trabalhista em vigor, com a maior eficácia possível. A propósito, o resultado da fiscalização, com a análise do quadro vislumbrado na ação fiscal, permite diagnosticar o que representa efetivamente uma limitação fática ou traduz um artifício ideológico. Por isso, o(a) Auditor(a)-Fiscal torna-se parte da estrutura de poder e assume papel peculiar, pois não apenas observa (inspeciona), mas se insere na relação de maneira participativa. Reforça-se: o observador, no contexto de complexidade, é simultaneamente sujeito.

Percebe-se, pois, a importância do pensamento sistêmico: o(a) Auditor(a)-Fiscal não representa um ruído externo; é mais um elemento da relação de trabalho subordinado, quando inicia a fiscalização do cumprimento da legislação de proteção ao trabalho. E, no conjunto histórico-social brasileiro, surge a dificuldade: pensa-se o(a) Auditor(a)-Fiscal como parte do Estado - do qual ele(a) realmente faz parte - e a sua presença é, muitas vezes, considerada uma invasão na esfera de propriedade e de autonomia privadas, dificultando muitas vezes a eficácia da atuação fiscal na adequação do meio ambiente do trabalho às normas de proteção do trabalho humano. A lavratura do auto de infração e a imposição de multas não promovem a eficácia da garantia da ordem pública.

Faz-se mister, para tanto, reconhecer que a relação de trabalho subordinado na sua essência já traz em si o elemento público, nos termos da ordem constitucional vigente.

A função, portanto, da fiscalização do trabalho é prevenir os conflitos e, assim, manter a integridade do sistema contra a sua ruptura motivada por ruídos externos. A fiscalização do trabalho constitui, portanto, um filtro contra a dominação de um discurso sobre o outro. A atividade fiscalizatória institucionaliza a ordem pública nos elementos das relações de trabalho subordinado, ou seja, constitucionaliza ${ }^{399}$ a dinâmica das relações de trabalho subordinado. Para tanto, o(a) Auditor(a)-Fiscal, consciente da complexidade do

\footnotetext{
${ }^{398}$ GALDINO, Flávio. op. cit., p. 253.

399“Constitucionalizar", para os fins desse estudo, é interpretar e aplicar as normas de proteção ao trabalho, com base nos princípios e valores contemplados na Constituição Federal.
} 
processo dinâmico do poder nas relações de trabalho subordinado, torna-se capaz de investigar a racionalidade subjacente aos conflitos.

O(a) Auditor(a)-Fiscal do Trabalho, no exercício da sua atividade parametrizada pelos direitos sociais fundamentais, deve então recorrer aos elementos jurídicos disponíveis oriundos do discurso humanizador das relações sociais. O verdadeiro papel da fiscalização do trabalho em uma ordem constitucional pautada pelo referencial de dignidade e democracia é equalizar o conflito, valendo-se dos instrumentos jurídicos disponíveis. O problema surge quando se operam mudanças bruscas no quadro econômicosocial com impactos imediatos na legislação trabalhista. $\mathrm{O}$ fenômeno denominado por "flexibilização" representa um exemplo inquietante para análise.

\section{5. "Flexibilização": por um sistema jurídico maleável?}

Se é certo que a afirmação histórica dos direitos humanos ${ }^{400}$ revelou e corrigiu determinadas distorções, identificam-se discursos jurídicos que tentam mascarar a preponderância do discurso da sociedade capitalista. No campo das relações de trabalho, entre os anos 80 e 90 do século XX, aflorou o fenômeno conhecido como flexibilização. Sob o argumento de que a legislação trabalhista, de caráter essencialmente protetiva, não se justificaria em momentos de transformações econômicas e apresentava-se, então desgastada, propugnaram-se modificações na organização e na disciplina do trabalho. Exigia-se a reformulação do sistema jurídico de proteção do trabalhador, com o fim explícito de reduzir direitos. Um dos argumentos dos seus defensores é de que a sociedade havia mudado e um novo perfil de trabalhador seria exigido.

Roger Blanpain conceitua flexibilidade ${ }^{401}$ como sendo

\footnotetext{
${ }^{400}$ Faz-se uso da expressão título da obra de Fábio Konder Comparato: A afirmação histórica dos direitos humanos, cit.

${ }^{401}$ Annie Thébaud-Mony e Graça Druck esclarecem que, em alguns estudos, os autores utilizam os termos flexibilização e flexibilidade como sinônimos. Porém, é possível distinguir as duas figuras. Por flexibilização, entendem-se "condições exigidas, impostas ou construídas por uma nova configuração em transição e essa é a diferença em relação ao uso do termo flexibilidade, que se refere a uma etapa ou situação já constituída e estabelecida, seja no âmbito do processo/organização do trabalho, seja no quadro mais geral e sistêmico da economia e da sociedade capitalista". (THÉBAUD-MONY, Annie; DRUCK, Graça. Terceirização: a erosão dos direitos dos trabalhadores na França e no Brasil. In: DRUCK, Graça; FRANCO, Tânia. A perda da razão social do trabalho: terceirização e precarização. São Paulo: Boitempo Editorial, 2007. p. 29).
} 
=adaptabilidade=desregulamentação, ou maior liberdade de administração para o gerenciamento dos negócios; refere-se a muitos assuntos e pode assumir várias formas. A flexibilidade pode ser unilateral, individual, legislada ou negociada, sendo que esta última significa que os meios de flexibilização se tornam possíveis somente se forem acordados com os representantes dos empregados, em nível empresarial ou até mesmo setorial. Neste sentido, discute-se a flexibilidade como:

\section{-contratos de emprego:}

- contratos de curto prazo consecutivo;

- meio expediente;

- trabalho temporário;

- contratos resgatáveis;

- contratação de pessoal;

- restrições flexíveis de contratação e dispensa.

\section{•remuneração}

- revogação de salário mínimo;

- acordo descentralizado;

- pagamento individualizado, baseado no mérito de cada um;

- opções salarais (permissão ao empregado de escolher entre pagamento direto ou férias prolongadas, maiores ou menores direitos a pensão etc.).

\section{-horário de trabalho}

- remanejamento do horário de trabalho;

- antecipação de aposentadoria;

- turnos;

- trabalho noturno;

- trabalho no fim de semana;

- anualização da jornada de trabalho ou coisa parecida. ${ }^{402}$

Marcelo Ribeiro destaca quatro tendências de flexibilização:

a) Flexibilização funcional: enxugamento dos postos de trabalho e não se exigem especificações para a realização dos processos de trabalho e o seu exercício;

b) Flexibilização legal e contratual: desregulamentação, diversificação e precarização das modalidades de trabalho;

\footnotetext{
${ }^{402}$ BLANPAIN, Roger. O futuro do acordo coletivo. In: ANAIS DO SEMINÁRIO INTERNACIONAL RELAÇÕES DE TRABALHO - ASPECTOS JURÍDICOS, SOCIAIS E ECONÔMICOS, Brasília: Edição da Secretaria Executiva do Ministério do Trabalho, 1998. p. 117.
} 
c) Flexibilização espaço-temporal: não há mais parâmetros espaçotemporais para o trabalho, ao qual fica o trabalhador disponível todo o tempo e em qualquer lugar;

d) Flexibilização salarial: preferência pela remuneração por metas, produtividade e ações de desenvolvimento pessoal e profissional. ${ }^{403}$

O Direito do Trabalho passou pela flexibilização de direitos de maneira "inconsciente", se esforçando para afastar as características da sombra ${ }^{404}$. Cabe mencionar o exemplo da Lei n. 9.601 de 21 de janeiro de 1998, que dispõe sobre o contrato de trabalho por prazo determinado. Permitiu-se que os trabalhadores contratados nos moldes dessa lei tivessem os recolhimentos de FGTS reduzidos de $8 \%$ para 2\% (artigo $2^{\circ}$, inciso II). A justificativa para tanto está no aspecto econômico, afinal, nesse caso, o princípio da igualdade, tão caro aos liberais, foi "relativizado" em nome das "necessidades" da sociedade de produção capitalista.

Para Amauri Mascaro Nascimento, a flexibilização do Direito do Trabalho claramente apresenta-se como uma noção oriunda das necessidades de natureza econômica, que justificariam o abandono dos direitos de proteção ao trabalhador, contemplados pelo ordenamento jurídico positivo ${ }^{405}$. Com a flexibilização, "privatiza-se" o contrato de trabalho e a perda do referencial do trabalho como matéria de ordem pública

\footnotetext{
${ }^{403}$ RIBEIRO, Marcelo. op. cit., p. 43.

${ }^{404}$ Sob o paradigma racional-científico, o que não pode ser aferível metricamente não pode ser valorado. No entanto, avaliar tão-somente o que se encontra na esfera da realidade aparente (fachada) não é suficiente para compreender o homem e, mais ainda, a dinâmica das relações humanas. Jung, ao romper com a lógica aristotélica do terceiro excluído, identificou no homem o seu lado sombrio, o qual denominou como sombra. O homem traz em si o lado luminoso e o lado sombrio; o masculino e o feminino. Os chineses retrataram essa polaridade psíquica no símbolo Yin e Yang: "basicamente Yang e Yin representam os dois pólos espirituais em torno dos quais gira toda vida. Yang e Yin existem em homens e mulheres, mas são também princípios cósmicos, e sua interação e relação determinam o curso dos acontecimentos". (SANFORD, John A. Os parceiros invisíveis: o masculino e o feminino dentro de cada um de nós. 4. ed. São Paulo: Paulinas, 1986. p. 15.) A sombra é um arquétipo. "Os arquétipos formam a base dos padrões de comportamento instintivos e não aprendidos, que são comuns a toda espécie humana e que se apresentam à consciência humana de certas maneiras típicas". (Id. Ibid., p. 13.) A sombra comporta todos os conhecidos pecados cardeais. (STEIN, Murray. Jung: o mapa da alma: uma introdução. São Paulo: Cultrix, 1998. p. 99). A tendência do indivíduo é manter ocultos os traços sombrios. Contudo, eles existem em estado latente e quanto menos são enfrentados mais nefastos podem se tornar, quando manifestados. São os exemplos históricos de Hitler ou Stálin, trazidos por Murray Stein. Eles adquiriram tanto poder que permitiram que sua sombra aflorasse sem limites, satisfazendo "suas paixões perversas no mais alto grau imaginável". (Id., loc. cit.). Quando se adquire poder, a manifestação da sombra, ignorada pela consciência, pode resultar em catástrofes psíquicas, como perversão e ofensas à dignidade humana, como ocorre em ambientes de trabalho propícios à prática de assédio moral. A sombra coletiva - o lado cruel, agressivo, indomável fomentado pelas instituições sociais - é "domada" pelo Direito. O Direito reconhece o exercício do poder do capital e os seus mecanismos de subjugação humana, e o torna aceitável por meio de normas e institutos jurídicos, que objetivam estabelecer limites para a manifestação da sombra coletiva (da sociedade capitalista).

${ }^{405}$ NASCIMENTO, Amauri Mascaro. Curso de direito do trabalho, cit., p. 120.
} 
justifica a mitigação do alcance do poder de polícia do Estado. Mas, se a flexibilização compromete o sistema juslaboral, por que se admite?

Uma resposta para essa indagação estaria no fundamento do sistema de regulação das relações de trabalho. A legislação trabalhista, conforme já foi aqui estudado, visou precipuamente afastar um cenário de dominação e subjugação do trabalhador. Por isso, chega-se a afirmar que as normas trabalhistas são predominantemente do tipo comando e controle e apenas em segundo plano se destinariam a incentivar condutas. Para conter o impacto negativo de regras universais e obrigatórias ou para atender a situações especiais, elas comportariam flexibilizações ${ }^{406}$.

Mas, além disso, há o cenário de complexidade e o excesso de ruídos, que fragilizam os institutos de direito do trabalho. Isso porque não há uma razão única que fundamenta a pluralidade de regulações que orientam as relações de trabalho; a concorrência de várias racionalidades provoca a inconsistência do sistema juslaboral. Na concepção de uma lei trabalhista, podem ser identificados objetivos econômicos, sociais e políticos com influências externas e a própria história de cada país ${ }^{407}$. A CLT é exemplo disso. Como destaca Gunther Teubner, observa-se que o Direito é submetido a constantes ataques de "cavalos de Tróia", o que hoje leva a normativas extralegais dentro do espaço do Direito. ${ }^{408}$

Como resultado, tem-se a multiplicação das leis, a qual, conforme aponta Celso Fernandes Campilongo, rompe com a noção de sistema jurídico fechado e piramidal. Ademais, modelos caros ao direito positivo como o de codificação, herdado da tradição napoleônica e reproduzido nas mesas de juízes e advogados, perde importância. ${ }^{409}$ Prossegue o autor para destacar que a necessidade de adaptar uma legislação fruto da visão "fechada" do ordenamento às condições mais flexíveis resulta, nos códigos recentes, em uma estrutura "aberta". Inevitável, então, a critíca formalista a leis como o Código de Defesa do Consumidor, sob a acusação de serem dotadas de pouca técnica. ${ }^{410}$

Além da acusação de "pouca técnica" lançada contra os textos codificados, convive-se com uma pluralidade de focos de interesse e de fontes de pressão nas

\footnotetext{
${ }^{406}$ PINHEIRO, Armando Castelar; SADDI, Jairo. op. cit., p. 512.

${ }^{407}$ Id., loc. cit.

${ }^{408}$ TEUBNER, Gunther. Altera pars auditur: law in collision of discourses, cit., p. 156.

${ }^{409}$ CAMPILONGO, Celso Fernandes. op. cit., p. 42.

${ }^{410}$ Id., loc. cit.
} 
sociedades complexas, que expõe o esgotamento do processo regulatório do Estado ${ }^{411}$. Como consequência da fragilidade do arcabouço jurídico estatal, produz-se uma "legalidade potencialmente fragmentária e assimétrica, cuja validade formal exerce funcionalmente o papel de uma complexa teia simbólica na qual muitas decisões com grandes implicações sócio-econômicas são mascaradas, e em cujo âmbito o que realmente vale não é a letra da lei, o que é estatuído"412.

A questão é manter a integridade do sistema, por meio da sua autorreferência. Por autorreferência entende-se "aquilo que pode ser compreendido como elemento, parte, aspecto, processo, interação de (ou em) um sistema voltado, envolvido, inexoravelmente, consigo mesmo"413.

Não se negam os pontos de contato entre os sistemas, como a relação entre direito e economia. Mas a preocupação é quanto ao risco de perda das referências internas e formas de distinção com o ambiente ${ }^{414}$, decorrentes do abandono pelo Direito, como sistema, do seu código próprio (direito/não direito), passando a operar com os códigos da política, da ciência ou da moral. ${ }^{415}$ Gunther Teubner questiona se a sua proposta de traduzir os conflitos entre os discursos para o direito, decidir sobre eles e controlar as consequências argumentativamente não seria a projeção de um mundo ideal. Teubner responde negativamente. Para ele, essa dinâmica da observação de conflitos pelo sistema jurídico refere-se à prática corrente de uma análise econômica do direito, pois, em um primeiro momento, o direito reconstrói as transações econômicas em termos legais com a ajuda da

\footnotetext{
${ }^{411}$ Ver FARIA, José Eduardo. Direito e economia na democratização brasileira, cit., p. 134-137.

${ }^{412}$ Id. Ibid., p. 136.

${ }^{413}$ RODRIGUES, Léo Peixoto. op. cit., p. 111.

414،Para Luhmann, existe um ambiente, uma totalidade que pode ser vista como um ambiente e que é complexa. Quando, neste ambiente, se formam sistemas, através de elementos/processos (existentes nesse ambiente) que se enlaçam de forma recursiva, retro-alimentada, diferenciando-se desse ambiente, temos, então, o que Luhmann irá chamar de redução da complexidade desse ambiente, pois houve uma operação de diferenciação: uma coisa que continuou sendo ambiente e outra coisa que pode ser chamada de sistema auto-referente, autopoiético. Esse sistema que se formou, ou seja, essa unidade que se fez diferença, justamente por se diferenciar, passa a se constituir numa identidade. Essa identidade poderia ter sido outra qualquer, muitas outras, dadas as infinitas possibilidades oferecidas pela complexidade do ambiente; entretanto, como o surgimento, a emergência de um sistema só pode se dá através da seleção de possibilidades - por isto o caráter contingente de todo sistema autopoiético -, aquela seleção de possibilidades que se constituiu como um sistema atual constitui-se ao mesmo tempo numa identidade/sentido, isto é a forma que a própria auto-referência assume; o sistema mesmo. Luhmann (1998), entretanto, alerta que, embora a existência de um sistema implique na redução da complexidade do "sistema-mundo", isto não significa que o sistema em si não apresente complexidade - redução da complexidade mediante complexidade. Isto porque Luhmann admite que a relação entre os elementos internos do sistema, não se dá apenas de forma quantitativa, mas de forma qualitativa." (RODRIGUES, Léo Peixoto. op. cit., p. 115).

${ }^{415}$ CAMPILONGO, Celso. Política, sistema jurídico e decisão judicial. São Paulo: Max Limonad, 2002. p. 127.
} 
análise econômica. Em um segundo passo, ele ajusta a argumentação legal às possíveis e já materializadas consequências economicamente danosas. Por fim, ele reformula as normas legais com base nessas transformações. ${ }^{416}$ Porém, essa dinâmica não autoriza a hegemonia da teoria econômica sobre o Direito. A flexibilização de direitos fundamentais de proteção ao trabalhador representa uma perda de referencial do sistema jurídico em face da interferência de outros códigos, em especial o econômico, quando o discurso se restringe à viabilidade econômica ou não de manutenção do sistema legal de proteção ao trabalhador.

Teubner, então, alerta que é indispensável estar atento ao imperialismo ou mesmo o totalitarismo da teoria econômica. Segundo o autor, se o direito se abrir para as demandas da economia dessa forma, ele deve se abrir para outros discursos da mesma forma. Por essa razão, Teubner conclui que a tarefa é generalizar esse jogo de "renvoi", como praticada pelo Direito e Economia, e aplicá-lo à multiplicidade de discursos na sociedade. ${ }^{417}$

Como resultado de uma flexibilização excessiva, os trabalhadores são impedidos de prosseguirem em suas profissões e carreiras, ensejando ainda restrição no padrão salarial e no nível de vida; o impacto dessas transformações reflete-se na vida da sociedade como um todo $^{418}$. Na esteira da flexibilização, a Lei n. 10.593, de 06 de dezembro de 2002, previu expressamente em seu artigo 11 , inciso III $^{419}$, a atribuição de natureza arrecadatória da Auditoria-Fiscal do Trabalho, o que é passível de críticas, dado o espírito e a vocação da Administração Pública do Trabalho, contrária a um viés prioritariamente arrecadador ${ }^{420}$.

A tendência flexibilizadora dessa forma conduzida demonstra o enfraquecimento do Estado, fato esse que, conforme observa Marcelo Afonso Ribeiro, promove uma mudança sociopolítica importante, "pois sai a sociedade com conflitos e entra a sociedade de interesses privados, na qual não há possibilidade de conflitos, nem de preservação do bem público" 421 . Proteger a saúde do trabalhador é uma forma de preservar o bem público. A adequação ou não do comportamento das partes da relação de trabalho subordinado com o compromisso de dignidade insculpido na Constituição Federal de 1988 reflete nos dados

\footnotetext{
${ }^{416}$ TEUBNER, Gunther. Altera pars auditur: law in collision of discourses, cit., p. 172.

${ }^{417}$ Id., loc. cit.

${ }^{418}$ ARAUJO, Eneida Melo Correia de. As relações de trabalho: uma perspectiva democrática. São Paulo: LTr, 2003. p. 130.

${ }^{419}$ BIGNAMI, Renato. op. cit., p. 37.

${ }^{420}$ Id., loc. cit.

${ }^{421}$ RIBEIRO, Marcelo Afonso. op. cit., p. 81.
} 
sobre acidentes de trabalho. Seguem resultados de investigações realizadas por AuditoresFiscais do Trabalho entre janeiro e agosto de $2010:^{422}$

A lista abaixo relaciona os fatores causais que aparecem em maior número nos relatórios de análise de acidente e correspondem a cerca de metade do total dos fatores citados.

\begin{tabular}{|l|c|}
\hline Descrição & $\begin{array}{c}\text { Total de } \\
\text { Acidentados }\end{array}$ \\
\hline Modo operatório inadequado a segurança / perigoso & 328 \\
\hline Falha na antecipação / deteç̧ão de risco / perigo & 319 \\
\hline Ausência / insuficiência de treinamento. & 205 \\
\hline Falta ou inadequação de análise de risco da tarefa & 183 \\
\hline $\begin{array}{l}\text { Sistema / dispositivo de proteção ausente } \\
\text { /inadequado por concepção }\end{array}$ & 172 \\
\hline Improvisação & 132 \\
\hline $\begin{array}{l}\text { Procedimentos de trabalho inexistentes ou } \\
\text { inadequados }\end{array}$ & 132 \\
\hline $\begin{array}{l}\text { Uso impróprio / incorreto de equipamentos } \\
\text { materiais /ferramentas }\end{array}$ & 127 \\
\hline Ausência / insuficiência de supervisão. & 97 \\
\hline $\begin{array}{l}\text { Designação de trabalhador não qualificado / treinado } \\
\text { /habilitado }\end{array}$ & 97 \\
\hline Falta de planejamento / de preparação do trabalho & 94 \\
\hline Dificuldade de circulação & 62 \\
\hline $\begin{array}{l}\text { Intervenção em condições ergonomicamente } \\
\text { inadequadas }\end{array}$ & 62 \\
\hline Espaço de trabalho exíguo / insuficiente. & 94 \\
\hline Posto de trabalho ergonomicamente inadequado \\
\hline $\begin{array}{l}\text { Tolerância da empresa ao descumprimento de } \\
\text { normas de segurança }\end{array}$ & 93 \\
\hline Tarefa mal concebida & and \\
\hline
\end{tabular}

\footnotetext{
${ }^{422}$ BOLETIM Sirena: análise de acidentes de trabalho, n. 1, jan./ago. 2010. Disponível: $<$ http://www.moodle.fmb.unesp.br/file.php?file=\%2F52\%2FNoticias\%2FNoticias_2010\%2Fboletim_jan_a go_2010.pdf>. Acesso em: 20 set. 2010.
} 
O problema ganha maior importância se imaginar que a ampliação dos riscos do trabalho decorre da organização do trabalho. Na esfera da disciplina das relações de trabalho subordinado, as intervenções econômicas são marcantes na determinação do modelo de organização de trabalho, como no exemplo na introdução da jornada de 12 X36, a ser analisado no próximo capítulo. É de extrema relevância identificar as intervenções não-mediatizadas, a fim de evitar distorções no sistema jurídico de proteção aos direitos fundamentais, in casu, dos trabalhadores.

Destaca Angelo Salento que "a crise do direito do trabalho é antes de tudo um produto da luta pelas intepretações, que se joga no campo do direito: interpretações das normas e interpretações dos contextos das relações que ambicionam regular" ${ }^{423}$

Ao lado de um cenário de pluralidade de referenciais e discursos, Marcus Orione Gonçalves Correia postula que os direitos humanos talvez sejam o meio para que "se possa chegar à redenção e à fuga desta estrutura contratualista liberal - que impregna essencialmente também todos os direitos sociais e suas formas de manifestação" ${ }^{424}$. Diante disso, resta, então, analisar a base sistêmica estrutural e organizacional dos direitos humanos, a qual converge e se concentra na ideia de dignidade humana. A indeterminação dos conceitos, por exemplo, contribui para garantir a dignidade, até mesmo pelas intensas e constantes mudanças impingidas no mundo do trabalho.

Marcelo Neves entende que

a Constituição determina como e até que ponto o sistema jurídico pode reciclar-se sem perder sua autonomia operacional. A falta de uma regulação estritamente jurídica da capacidade de aprendizado ou reciclagem do sistema jurídico conduz - em uma sociedade hipercomplexa, com conseqüências muito problemáticas - a intervenções diretas (não-mediatizadas pelos próprios mecanismos jurídico-sistêmicos) de outros sistemas sociais, sobretudo do político, no direito. ${ }^{425}$

Por essa razão, a fim de "constitucionalizar" as relações de trabalho subordinado, é indispensável discutir sobre a construção do conceito de dignidade na sociedade pós(hiper)-moderna.

\footnotetext{
${ }^{423}$ SALENTO, Angelo. op. cit., p. 232.

${ }^{424}$ CORREIA, Marcus Orione Gonçalves. op. cit., p. 131.

${ }^{425}$ NEVES, Marcelo. A constitucionalização simbólica. São Paulo: Martins Fontes, 2007. p. 71-72.
} 


\section{CAPÍtULO IV. A DIGNIDADE COMO FUNDAMENTO DA ORGANIZAÇÃO DAS RELAÇÕES DE TRABALHO SUBORDINADO}

\section{A integração do Direito do Trabalho no Brasil em torno da dignidade humana}

O trunfo do exercício de poder na relação de trabalho reside na aparente ausência de coação. Desde o início das relações de trabalho subordinado, a preocupação era desatrelar o novo modo de exploração de mão-de-obra dos modelos anteriores: escravidão e servidão. Mas como foi possível desvincular o modelo de opressão do universo das relações de trabalho? Uma ordem normativa pautada pelos direitos fundamentais redimensionou as relações de trabalho e introduziu o fundamento da dignidade na esfera laboral.

\subsection{O sentido da dignidade e os direitos fundamentais dos trabalhadores}

“O que chamamos de 'trabalho' é uma invenção da modernidade". ${ }^{426} \mathrm{O}$ alerta de André Gorz é fundamental para iniciar uma breve investigação sobre a dignidade humana nas relações de trabalho. O que se viu até o presente momento é a importância da ideia de discurso, como referência para a dinâmica social. Como o discurso não é um dado aferível metricamente, pois é pautado por valores, a construção do sentido da dignidade no trabalho depende das referências adotadas pelo observador-sujeito. $\mathrm{O}$ objetivo nesse item é discutir como o Direito inclui a dignidade no trabalho como padrão de organização do sistema juslaboral, por intermédio do modelo de reconhecimento de direitos fundamentais ao trabalhador.

O sentido do trabalho é fruto da racionalidade presente nos discursos. Marcus Orione Gonçalves Correia destaca que Hans-Georg Gadamer, "assim como outros (Niklas Luhmann e, no Brasil, Tércio Sampaio, só para citar alguns exemplos), mencionam a

\footnotetext{
${ }^{426}$ GORZ, André. Metamorfoses do trabalho: crítica da razão econômica. 2. ed. Trad. Ana Montoia. São Paulo: Annablume, 2007. p. 22.
} 
importância da linguagem para a construção de certas racionalidades". ${ }^{427}$ Dessa maneira, a concepção de trabalho depende da linguagem, do código adotado por cada sistema.

A realidade, portanto, pode ser interpretada de acordo com o referencial escolhido. A escolha, por sua vez, deriva da análise de oportunidades e resulta da aplicação de uma escala de preferências. Por isso, "no plano da ciência, a interpretação tem-se destacado, mais modernamente, por não ser refém da ideia de neutralidade axiológica. Assim, certos ramos da ciência têm-se destacado por entender que há, sim, algum subjetivismo na compreensão de seus fenômenos" ${ }^{, 428}$. Subjetivismo, contudo, não corresponde à ausência de parâmetros. Ao intérprete não cabe agir como Humpty Dumpty, personagem de Lewis Carroll, da obra "Alice através do espelho". 429

A dificuldade está em como avaliar as bases preponderantes que servem de referência para a atividade interpretativa. Do ponto de vista positivista, afastou-se tecnicamente a discussão axiológica, quando na verdade ela foi remetida a uma condição subjacente, em nome da objetividade dos postulados jurídicos. Em relação ao trabalho, na sociedade burguesa, ele se apresentou como um princípio, não apenas para garantir a sobrevivência dos que não detinham os bens de produção, mas, como explicita Ulrich Beck, "porque se queria contra-arrestar a ameaça representada por 'sujeitos' não integráveis ao controle e ao conjunto de sentido da sociedade" ${ }^{430}$. Dessa maneira, existia um sentido de sociedade pautado não em dados objetivos e neutros a quaisquer interesses. Conforme explica Ulrich Beck, a ideia de trabalho construída pela sociedade burguesa vincula-se a uma "fixação cotidiana de sentido e controle, uma estrutura de domínio interiorizada" [grifo nosso] ${ }^{431}$.

Foi a partir desse desejo de "construir uma atividade via mercado de trabalho" que foi possível a "auto-adaptação e auto-ajustamento dos indivíduos à estrutura de domínio

\footnotetext{
${ }^{427}$ CORREIA, Marcus Orione Gonçalves. op. cit., p. 121.

${ }^{428}$ Id., loc. cit.

${ }^{429}$ Em “Alice através do espelho", Alice pergunta a Humpty Dumpty qual o significado que ele emprega a palavra "glória", porque ela não entende o que ele quer dizer. Humpty Dumpty responde que é óbvio que ela não saiba o significado até que ele mesmo o diga. E para ele "glória" é um argumento arrebatador, infalível. Alice contesta, porque "glória" não tem esse sentido. Então, Humpty Dumpty diz, em tom de escárnio: "Quando eu uso uma palavra, ele significa apenas o que eu quiser que ela signifique - nem mais, nem menos". Alice indaga: "A questão é se você pode fazer as palavras significar várias coisas tão diferentes". A resposta de Humpty Dumpty não deixa margem a mais dúvidas: "A questão é quem manda isso é tudo". (CARROLL, Lewis. Alice's adventures in wonderland and through the looking-glass and what Alice found there. London: Penguin Classics, 2009. p. 186.)

${ }^{430}$ BECK, Ulrich. op. cit., p. 164.

${ }^{431}$ Id., loc. cit.
} 
social”432. Pode-se ampliar o entendimento do autor para afirmar que essa ideia foi absorvida pelo positivismo jurídico por meio da formatação do contrato de trabalho subordinado. Nessa esteira, Marcus Orione Gonçalves Correia pontua que "a função do direito, e mais especificamente do direito do trabalho, em especial por meio da figura do contrato de trabalho, seria a de colaborar neste processo de organização parcial e divisão social do trabalho" "433. O modelo de contrato adotado se baseou em um "conjunto de abstrações que, ao separar-se ideológica e ficticiamente dos contextos de onde se dão as situações concretas entre os indivíduos e os grupos, normalizam, legitimam e legalizam posições prévias de desigualdade com o objetivo de reproduzir-se infinitamente" ${ }^{\text {434 }}$.

O indivíduo não é apenas elemento do sistema econômico, mas ser humano partícipe da construção de sentido do trabalho. A crença na razão absoluta não se sustenta por si só, como foi analisado no início deste estudo. O observador é parte da construção do sentido do que observa. Dessa forma, o conteúdo humano (subjetivo) é indispensável para a formatação do conceito dos elementos; ou seja, o olhar do sujeito submete-se à organização do sistema. Logo, não é possível imaginar o universo das relações de trabalho sob um ponto de vista exclusivamente técnico-científico, como foi concebido gerencialmente em uma perspectiva taylorista-fordista.

Não se vislumbraria a tão decantada neutralidade axiológica proposta pelo positivismo jurídico. O desafio, dessa maneira, deixa de ser a introdução de conteúdo axiológico no sistema jurídico - porque já está presente - para ser a identificação dos valores efetivamente perseguidos. O Direito vem estimular - em termos econômicos - as condições de emergência de cooperação entre os agentes e - em termos psicossociais garantir o equilíbrio entre as estruturas de poder em conflito na sociedade. Isso significa que o Direito não impõe ruptura, mas conforma os interesses com base em um plano de referência jurídico legitimado pela sociedade ${ }^{435}$.

\footnotetext{
${ }^{432}$ BECK, Ulrich. op. cit., p. 164.

${ }^{433}$ CORREIA, Marcus Orione Gonçalves. op. cit., p. 129.

${ }^{434}$ HERRERA FLORES, Joaquín. La construcción de las garantías: hacía una concepción antipatriarcal de al libertad y la igualdad. Revista do Departamento de Direito Trabalho e Seguridade Social da Faculdade de Direito da Universidade de São Paulo, São Paulo, v. 2, n. 4, p. 33, jul/dez. 2007.

${ }^{435}$ A questão é que nem sempre a legitimidade corresponde ao que é legal. "Legitimidade refere-se ao que os indivíduos percebem como justo e razoável, não obrigatoriamente coincidindo com o que entendem como legal. (...) O conceito de legitimidade possui fortes componentes psicológicos, relacionados com crenças, experiências, aprendizagens anteriores dos indivíduos e esse complexo estará presente nas ações judiciais, justificando-as, conscientemente ou não, para aqueles que as iniciam". (FIORELLI, José Osmir et al. Psicologia aplicada ao direito. 3. ed. São Paulo: LTr, 2010. p. 34-35).
} 
Conforme se depreende do exposto, essa tarefa depende da compreensão, no que tange o trabalho e dentro dos limites deste estudo, das estruturas de poder das relações de trabalho subordinado. A compreensão de como o trabalho é visto e vivenciado pelos observadores e sujeitos da relação de trabalho subordinado é fundamental para a construção do sentido e das expectativas acerca do próprio trabalho. Desse processo de construção de sentido afloram os valores. O sentido do trabalho, como foi visto no desenrolar deste estudo, passou por várias reconstruções, mas a mais pungente e significativa em termos de equilíbrio de forças sociais se processou com a introdução da dignidade na base estrutural do sistema jurídico.

\subsection{A dignidade no trabalho como conceito indeterminado}

Destaca Eneida Melo Correia de Araújo que o Direito do Trabalho tem características não comuns aos demais ramos tradicionais do Direito, de maneira que "as técnicas usuais do direito comum e a rigidez de suas formas não encontraram espaço de aplicação no novo ramo jurídico", pautado pelo conteúdo de ordem pública ${ }^{436}$. Como já foi apontado, não é possível determinar peremptoriamente o sentido de "ordem pública". Trata-se de um conceito indeterminado, formatado pela realidade presente no momento de estruturar o ordenamento jurídico.

A inserção dos conceitos indeterminados, como "ordem pública" e dignidade, gerou um desafio para a organização do sistema pautado nos moldes científico-positivistas. A dificuldade para promover os direitos fundamentais aflora exatamente da inadaptabilidade da sua natureza - indeterminada, complexa e nem sempre objetivável -, contrastante com todo o modelo de codificação do Direito, conforme o paradigma positivista. A dificuldade de adaptar os modelos é atual. Na apreciação de projeto de lei, na Comissão de Constituição e Justiça e Cidadania, o deputado Régis de Oliveira relatou parecer, em que entendeu pela inconstitucionalidade do projeto de lei n. 7.124/2002, uma vez que o mesmo

\footnotetext{
${ }^{436}$ ARAUJO, Eneida Melo Correia de. op. cit., p. 35.
} 
"tenta conceituar o dano moral e estabelecer os bens juridicamente tutelados, trabalho impossível, que o legislador não deve se arriscar". ${ }^{437}$ [grifo nosso]

A ideia de dignidade humana repousa na construção da noção de humanidade. Humano é o livre para decidir e dispor das coisas da natureza de acordo com sua vontade, ou seja, pode agir. Se essa for a forma de conceber a dignidade - correlata direta da liberdade -, a dignidade é uma construção especulativa e não uma descrição de uma verdade a priori ou a descoberta de um fenômeno pela razão humana.

Ingo Wolfang Sarlet apresenta uma dimensão dúplice da dignidade. Para o autor, a dignidade pode ser: a) expressão da autonomia da pessoa humana; b) traduzida na necessidade de proteção conferida aos destituídos da capacidade de autodeterminação, por meio de ações da sociedade e do Estado. ${ }^{438}$ De qualquer forma, a dignidade se expressa na promoção de condições que permitam o ser humano agir na sociedade, isto é, na concessão de meios para que possa se autodeterminar. Contudo, resta avaliar a instigante questão: se a dignidade pressupõe a dimensão da autonomia da pessoa humana, haveria uma concepção de liberdade que compreendesse a humanidade dos Sísifos e dos Proteus, imersos nos dilemas do século XXI?

A primeira noção de liberdade é a de não impedimento. Dessa maneira, "ser livre é resistir ao impedimento (restrição) provocado pelo outro". ${ }^{439}$ O Estado Democrático de Direito visou dar novos contornos à noção de liberdade: a de agir politicamente. Inevitavelmente, o ordenamento jurídico assimilou os reflexos do poder democrático: o "indivíduo" cede espaço ao "coletivo"; os "direitos subjetivos" passam a conviver com "direitos de todos os homens".

As Constituições trazem em seu bojo os reflexos das mudanças paradigmáticas. Celso Lafer explica que

As Constituições contemporâneas têm características diferentes da Constituição-garantia dos séculos XVIII e XIX. Podem ser classificadas como Constituições-programáticas de ânimo dirigente, pois contém normas definidoras de programas de ação e de linhas de orientação. É por este motivo que as Constituições do século XX, com destaque para as que

\footnotetext{
${ }^{437}$ SENADO FEDERAL. Comissão de Constituição e Justiça e Cidadania. Parecer sobre Projeto de Lei $n^{\circ}$ 7.124, DE 2002 (Apensados os Projetos de Lei no. 1.443/2003, 1.914/2003 e 7.329/2010). Disponível em: <http://www.camara.gov.br/sileg/integras/777390.pdf>. Acesso em: 22 out. 2010.

${ }^{438}$ SARLET, Ingo Wolfgang. As dimensões da dignidade humana. Revista Brasileira de Direito Constitucional-RBDC, n. 9, p. 376, jun./jul.2007.

${ }^{439}$ FERRAZ JÚNIOR, Tércio Sampaio. Estudos de filosofia do direito: reflexões sobre o poder, a liberdade, a justiça e o direito, cit., p. 104.
} 
foram elaboradas no Segundo Pós-Guerra, contêm, além de regras que atribuem competências, princípios gerais. ${ }^{440}$

Entretanto, a consequência dessa evolução é se deparar com um Estado Social Democrático de Direito que apresenta limitações derivadas do paradigma da modernidade de que é tributário. A sustentação da óptica individualista expõe as fragilidades do sistema jurídico, o qual muitas vezes encontra sérias dificuldades em fornecer respostas satisfatórias. Por exemplo: se da liberdade de todos para trabalhar decorre o direito ao trabalho, então o mesmo poderia ser exigido individualmente, para a promoção de uma sociedade de pleno emprego? Daí questiona-se a capacidade do Estado para garantir o exercício e a proteção de direitos assegurados pela sua própria Constituição, diante do universalismo e dos escassos recursos. Tais questões geram instabilidade e não contribuem para estimular a cooperação entre indivíduos, que já percebem que suas ações refletem e são direcionadas no interior de um ambiente coletivo.

Quando a certeza dos modelos científicos mecanicistas é contestada, pois não conseguem formular os problemas e modelar as soluções de acordo com o quadro real da sociedade, as instituições concebidas a partir desse paradigma principiam um processo de degenerescência. Em especial, trata-se do pungente desafio de compreender a liberdade do século XXI. ${ }^{441}$

Adverte Norberto Bobbio que "ninguém pode pretender conhecer o destino da liberdade no mundo. Quem se limita a ser observador daquilo que acontece é tentado a fazer uma reflexão" ${ }^{442}$. Como lúcido observador desse cenário, Tércio Sampaio Ferraz Júnior apresenta uma nova fórmula de conceber a liberdade: ao invés da dignidade humana estar centrada na liberdade individual ou na máxima "a liberdade de um termina onde começa a liberdade do outro", propõe a dignidade humana centrada no "viver em livre comunicação um com o outro”. [itálico do original] ${ }^{443}$ E prossegue o autor:

\footnotetext{
${ }^{440}$ LAFER, Celso. A internacionalização dos direitos humanos: Constituição, racismo e relações internacionais. Barueri/SP: Manole, 2005. p. 12.

${ }^{441}$ É de se lembrar Albert Camus que, ao escrever sob o mito de Sísifo, professou que "as verdades esmagadoras desaparecem ao serem reconhecidas". (CAMUS, Albert. op. cit., p. 140).

${ }^{442}$ BOBBIO, Norberto. Eguaglianza e liberta, cit., p. 95.

${ }^{443}$ FERRAZ JÚNIOR, Tércio Sampaio. Estudos de filosofia do direito: reflexões sobre o poder, a liberdade, a justiça e o direito, cit., p. 137.
} 
o que deveria ser dito é que a liberdade de um começa onde começa a liberdade do outro. Essa fórmula talvez nos fizesse pensar que o indivíduo deva deixar de ser visto como um ente isolado (agente) que se relaciona com outros (paciente) e vice-versa, mas como um entecomunicativo, uma unidade agente/paciente, numa rede de conexões. ${ }^{444}$

$\mathrm{Na}$ medida em que os modelos (noção de Estado, indivíduo, liberdade, direito subjetivo) são questionados, pode-se dizer que se vivencia um momento de transição ${ }^{445}$. Se não é viável conceber um sentido unívoco para o trabalho, a construção desse sentido no cenário de complexidade principia pela premissa acima reproduzida, pautada por uma "rede de conexões". E, nesse quadro, a proposta é caminhar do egoísmo para a alteridade.

Desprovido de uma essência natural pré-concebida, capaz de conduzi-lo a melhores escolhas a partir da ação individual, o homem não se autoconstrói sozinho ${ }^{446}$. E quanto mais os direitos humanos se aproximarem da noção do "homem como ser real", mais eles serão concebidos como "direitos do ser humano". A diferença não é retórica. ${ }^{447}$

Ausente uma natureza humana pré-existente, o homem se inventa, a partir do simples fato de existir. ${ }^{448}$ Aqui a liberdade, por sua vez, acaba por se dissociar da noção de um objeto, de um elemento com o qual se identifique (por exemplo, a propriedade). Ser livre passa a ser um atributo da existência humana, pois o homem, "uma vez lançado no mundo, é responsável por tudo o que ele faz" ${ }^{449}$, incluindo suas escolhas. O homem não pode querer outra coisa, senão que a liberdade seja o fundamento de todos os valores, incluindo o trabalho humano.

\footnotetext{
${ }^{444}$ FERRAZ JÚNIOR, Tércio Sampaio. Estudos de filosofia do direito: reflexões sobre o poder, a liberdade, a justiça e o direito, cit., p. 137.

${ }^{445} \mathrm{~A}$ própria ciência promove suas mudanças e sua mola propulsora é um sentimento, como escreve Thomas S. Kuhn, "de que o paradigma existente deixou de funcionar adequadamente na exploração de um aspecto natureza, cuja exploração fora anteriormente dirigida pelo paradigma". E continua o autor: "Tanto no desenvolvimento político como no científico, o sentimento de funcionamento defeituoso, que pode levar à crise, é um pré-requisito para a revolução". (KUHN, Thomas S. op. cit., p. 126).

${ }^{446} \mathrm{Como}$ ser humano - e aqui envereda-se na esfera psicológico-social -, Erich Fromm, destaca que "a falta de relacionamento com valores, símbolos e padrões pode ser chamada de solidão moral; ela é tão intolerável quanto a solidão física, ou melhor, a solidão física somente se torna intolerável quando implica também solidão moral”. (FROMM, Erich. O medo à liberdade. 7. ed. Rio de Janeiro: Zahar, 1970. p. 26).

${ }^{447}$ Jean-Paul Sartre explica que, "no século XVIII, com o ateísmo dos filósofos, a noção de Deus é suprimida, mas não para afastar a ideia que a essência precede a existência". "Esta ideia", continua Sartre, "nós a encontramos em Diderot, em Voltaire e mesmo em Kant. O homem é possuidor de uma natureza humana; esta natureza humana (...) se encontra em todos os homens, o que significa que cada homem é um exemplar particular de um conceito universal: o homem" (SARTRE, Jean-Paul. L'existentialisme est un humanisme. Paris: Edition Gallimard, 1996. p. 28).

448، O homem não é outra coisa, a não ser aquilo que ele se faz". ("L'homme n'est rien d'autre que ce qu'il se fait"). (SARTRE, Jean-Paul. op. cit., p. 30).

${ }^{449}$ Id. Ibid., p. 40.
} 
Pondera Sartre que "nós queremos a liberdade pela liberdade e através de cada circunstância particular. (...) E em querer a liberdade, nós descobrimos que ela depende inteiramente da liberdade dos outros, e que a liberdade dos outros depende da nossa". ${ }^{450} \mathrm{~A}$ liberdade de um começa onde começa a liberdade do outro. ${ }^{451}$

Ao contrário do homem-indivíduo, o homem existencial vai de encontro com a ideia da unidade agente/paciente:

Quando nós dizemos que o homem se escolhe, nós entendemos que cada um entre nós se escolhe, mas, além disso, nós queremos dizer também que, ao se escolher, ele escolhe todos os homens. (...) Nossa responsabilidade é muito maior do que poderíamos supor, porque ela compromete a humanidade inteira. ${ }^{452}$

O trabalho, como valor humano, é um direito fundamental. Interpretar os direitos fundamentais é um agir em busca da garantia da vida humana em condições dignas. Há uma universalidade do homem, mas, como adverte Sartre, ela não é dada; "ela é perpetuamente construída". ${ }^{453}$

A dignidade resulta, nesse contexto, de uma realização humana, ou seja, é condição humana. O indivíduo como ente abstrato serviu como referência normativa, mas a liberdade se concebe no meio social, por meio da ação humana, pois:

O individuo não é mais, como na tradição clássica ocidental, a célula da sociedade. A possibilidade de se representar esta última como uma totalidade ou um organismo que tem nos indivíduos as suas "partes vivas" encontra-se, assim, definitivamente superada ${ }^{454}$.

Isso não significa que o indivíduo não possa influenciar as transformações do meio em que vive, mas que a noção de relações sociais extrapola a esfera do indivíduo-indivíduo e alcança um processo dinâmico entre indivíduo-ambiente-indivíduo. Essa forma de apreciar a realidade exige que a liberdade esteja cada vez mais imbricada com a noção de igualdade. Nos moldes juspositivistas, a igualdade, assim como a liberdade, parte da relação entre indivíduos confrontados entre si. Com base em um modelo que contempla a

\footnotetext{
${ }^{450}$ SARTRE, Jean-Paul. op. cit., p. 69-70.

${ }^{451}$ FERRAZ JÚNIOR, Tércio Sampaio. Estudos de filosofia do direito: reflexões sobre o poder, a liberdade, a justiça e o direito, cit., p. 137.

${ }^{452}$ SARTRE, Jean-Paul. op. cit., p. 31-32.

${ }^{453}$ Id. Ibid., p. 61.

${ }^{454}$ MARRAMAO, Giacomo. op. cit., p. 187.
} 
complexidade social, a igualdade ultrapassa os limites entre os indivíduos para ser uma referência para toda a coletividade. Por isso, a igualdade, no contexto de complexidade, promove-se pela via dos direitos fundamentais a determinada sociedade. Da mesma forma, garante-se a liberdade.

Embora os direitos fundamentais possam ser pleiteados como direitos subjetivos, a dignidade humana que os inspira é uma exigência social e que, no caso das relações de trabalho subordinado, extrapola o âmbito do empregador e do empregado. A morte de um trabalhador no exercício das suas atividades laborais, por exemplo, é um fato que mobiliza não somente o empregador e os familiares da vítima, mas impacta todo o meio ambiente de trabalho, o círculo social próximo ao local do acidente e, até mesmo, toda a sociedade. Por essa razão, o reconhecimento dos direitos fundamentais do trabalhador remodela o contrato de trabalho, que mantém os contornos de natureza individual e privada, mas, por definir aspectos e características de toda sociedade, passa a ser objeto de ordem pública. A garantia do cumprimento dos direitos fundamentais do trabalhador deixa de ser uma questão privada para se tornar interesse da coletividade.

O inadimplemento de uma obrigação derivada de um direito fundamental do trabalhador provoca danos que invadem as demais esferas sociais. Como mecanismo de verificação de cumprimento das normas trabalhistas, a atividade estatal de fiscalização do trabalho, então, precipuamente não se volta às questões do trabalhador individualmente considerado, e sim da prevenção dos riscos que a não observância de direitos fundamentais do trabalhador pode ocasionar para a sociedade.

Então a eficiência perseguida e base para a construção do Direito (segurança jurídica, previsibilidade e objetividade) não seria mais possível? Todo o arcabouço juslaboral existente não serviria mais? Se é possível discutir o modelo adotado especificamente no Brasil (objeto do próximo item desse trabalho), há de se concordar com o que escreve Marcus Orione Gonçalves Correia, pois "é claro que é melhor ter o direito do trabalho, o contrato de trabalho (ou melhor a relação de trabalho), ou normas de redução das prerrogativas de entidades de previdência complementar ou saúde complementar, e regras de proteção, do que não tê-las" 455

A dificuldade de compreensão dos Direitos Humanos, então, vem da adaptação lenta e gradual do sistema jurídico à sua nova organização estrutural. Conforme o já

\footnotetext{
${ }^{455}$ CORREIA, Marcus Orione Gonçalves. op. cit., p. 130.
} 
enunciado, no Direito do Trabalho, ponderar os interesses não se restringiria à aplicação da norma que seja mais favorável a esse ou aquele indivíduo, mas a norma favorável à realização das funções do sistema de proteção dos direitos fundamentais ${ }^{456}$.

Assoma, então, um tema pungente no contexto de complexidade da sociedade, traduzido na pergunta: como garantir a estrutura do sistema juslaboral para que o mesmo atenda à sua função de estimular condutas e alterar comportamentos, de sorte que atenda aos princípios e aos valores elegidos pelo conjunto social e expressos na Constituição? Esse é o problema aventado no pensamento moderno e ainda inquietante na atualidade: transformar um modelo individual em um universo de emergência de decisões coletivas. ${ }^{457}$

É certo, conforme visto nesse trabalho, que a ideia de contrato intermediou a construção do Estado, permitindo conceber a transformação ou reunião de decisões individuais em decisões coletivas. Entretanto, também é certo que, na experiência real em sociedade, a indagação persiste. Para essa indagação, não haverá resposta unívoca ou, nem mesmo, será possível conceber, nesse momento histórico, uma explicação. O que se pode extrair, a partir do pensamento sistêmico, é que o sentido da dignidade pode ser desenhado por várias racionalidades discursivas e que a consciência da presença da lógica discursiva é necessária para não corromper o sistema juslaboral. Como Teubner alerta, "os sistemas sociais desenvolveram dinâmicas internas tão poderosas e incontroláveis que não sobrecarregam somente os indivíduos, mas também operam efeitos desintegradores uns sobre os outros" $"$.

Enfim, o objetivo que se propõe é dialogar sobre as questões aqui trazidas e identificar elementos que permitam manter, construir, reconstruir ou reparar o modelo juslaboral brasileiro existente, com a finalidade precípua de delinear os contornos do sentido e conferir garantia à dignidade humana.

\subsection{A presença da liberdade nas relações de trabalho no Brasil}

A liberdade para trabalhar foi a base da relação de trabalho subordinado, amparado por um contrato firmado por homens livres e iguais. A superação dos modelos

\footnotetext{
${ }^{456}$ V. item. 3.2 do Capítulo 1.

${ }^{457}$ Cf. anotações das aulas do Prof. J. R. N. Chiappin Direito e economia, cit.

${ }^{458}$ TEUBNER, Gunther. Altera pars auditur: law in collision of discourses, cit., p. 155.
} 
escravagistas e servis afastou-se do conteúdo de violência explícita, mas não impediu o fenômeno da violência simbólica.

Quando se afirma a igualdade e a liberdade de todos os homens, aparentemente atribui-se ao homem a possibilidade de agir. Por isso, a coação não tem espaço nas relações de trabalho subordinado, dado que sua origem está em um contrato. O contrato representa uma declaração de vontade das partes, de sorte que nenhuma delas pode coagir a outra, isto é, agir no lugar da outra, sob pena de nulidade. Afinal, a coação "significa renúncia à possibilidade de regular a seletividade do outro e não a sua ação concreta; o coator escolhe pelo outro". 459

Embora não se identifique a coação, há um poder que impulsiona a ação do destinatário para uma direção definida, embora estejam presentes várias possibilidades aparentes de ação. Trata-se do poder de violência simbólica:

o destinatário continua tendo várias possibilidades de ação, mas estas possibilidades são neutralizadas de tal maneira que aparece uma só, contudo elas não desaparecem. (...) simplesmente neutralizo sua seletividade para que escolha a minha - isto é uma relação de poder. ${ }^{460}$

A sociedade capitalista opera sob o referencial do poder de violência simbólica. Sob o pretenso discurso da liberdade e igualdade, paulatinamente condiciona as ações humanas para o seu interesse.

O mito de Sísifo serve como recurso metafórico para interpretar o exercício do poder nas relações de trabalho subordinado. Sísifo é condenado e se submete à decisão dos deuses, empurrando ininterruptamente a rocha. Não consta no mito que houvesse algum carrasco ou feitor, obrigando-o ou impondo castigos. Sísifo poderia se recusar a prosseguir na tarefa e aguardar a imposição de outra condenação. Mas ele não age de outra forma. Da mesma maneira, a sociedade capitalista exerce um poder, que reduz a possibilidade de ação dos indivíduos. A violência - não explícita, mas simbólica - está representada pela opressão sofrida pelo homem (muitas opções de ação e uma só direção) e pela fragmentação da capacidade de reflexão sobre a sua essência.

Diante disso, o reconhecimento do trabalho livre no Brasil não promoveu a transformação do modelo individual (representada pela oligarquia econômica) em um

\footnotetext{
${ }^{459}$ SANTOS, Maria Celeste C. Leite dos. op. cit., p. 153.

${ }^{460}$ Id., loc. cit.
} 
modelo de emergência de decisões coletivas fundadas em princípios e valores da sociedade organizada. No Brasil, após a abolição da escravatura e a afirmação no plano formal da liberdade de todos os homens, não se concebeu o valor do trabalho sob uma perspectiva da condição humana e das suas necessidades. A exemplo do que ocorreu no início da industrialização européia nos séculos XVIII e XIX, o trabalho é compreendido como objeto, como fator de produção, tendência da visão mecanicista indispensável para a organização científica do trabalho. O cenário brasileiro apresenta ainda uma característica relevante. No pensamento liberal, a propriedade do trabalho pertence ao trabalhador que o vende nos termos estritos de um contrato livremente celebrado. Contraria o discurso liberal o fato de que o trabalho se apresente menos como escolha racional, e sim uma contingência. O Brasil da República Velha adota o liberalismo como discurso políticoeconômico, porém com a peculiaridade de manter os traços da cultura escravagista. $\mathrm{O}$ resultado disso é a acomodação do trabalho livre na estrutura patrimonialista da economia brasileira.

A perspectiva liberal aparece nas Constituições de 1824 e de 1891. Na Constituição de 1824, o liberalismo era parcial, porque a concentração dos poderes nas mãos do imperador e a escravidão dos negros contrariavam os ideais liberais. Por outro lado, na Constituição de 1891, a influência do constitucionalismo norte-americano promoveu os contornos liberais, mas o Brasil jamais vivenciou o liberalismo, dado o caráter patrimonialista e protecionista presente na cultura política nacional ${ }^{461}$.

A base econômica da sociedade, situada no âmbito rural, até então se dividia entre senhores e escravos. Caio Prado Júnior expõe que, "quem não fosse escravo e não pudesse ser senhor, era um elemento desajustado, que não se podia entrosar normalmente no organismo econômico e social do país" ${ }^{462}$. Dada a impossibilidade de aproveitar a mão-deobra escrava recém-liberta nos setores da produção urbana nascente, majoritariamente serão aqueles "elementos desajustados" que comporão "um largo, fácil e barato suprimento de mão-de-obra"463. Tal fato é marcante no processo de industrialização brasileira, o qual permitiu "entrosar no trabalho produtivo normal uma categoria importante da população que vivera até aí à margem dele" ${ }^{464}$. Segundo Caio Prado Júnior, a indústria brasileira não sairá da mediocridade nas primeiras décadas do século XX e a "expansão da lavoura do

\footnotetext{
${ }^{461}$ SARMENTO, Daniel. op. cit., p. 30-31.

${ }^{462}$ PRADO JÚNIOR, Caio. História Econômica do Brasil. 43. ed. São Paulo: Brasiliense, 1998. p. 198.

${ }^{463}$ Id., loc. cit.

${ }^{464}$ Id., loc. cit.
} 
café continuará como dantes, se não com ritmo ainda mais acentuado, sob o regime do trabalho livre de imigrantes europeus" 465 .

O panorama geral desenha-se com a dificuldade de adaptação do sistema econômico brasileiro à ideia de trabalho livre. A origem do proletariado nacional trazia em seu bojo uma concepção de sociedade fundada no sistema escravocrata. A inserção do trabalho livre "não se fará sem um compromisso de que resultaria um tipo de relações de trabalho que sem serem servis, conservarão traços acentuados do regime abolido", que contribuíram para as contradições econômicas e sociais verificadas posteriormente ${ }^{466}$. Na República Velha, persiste a noção de que o trabalho deve ser explorado de maneira desmedida, justificada pela aquisição não só da capacidade de produção, mas do próprio corpo humano. A remuneração do trabalho não rompe com a lógica de desumanização no processo entre interação atividade econômica e trabalho humano, pois

Nosso 'feudalismo achamboado' - na expressão de Euclides da Cunha -
afirmou, desde sempre, com solidez e crueldade, uma desigualdade
fundamental. Desigualdade fundada não na estirpe (afinal, nossa
'aristocracia' jamais teve reconhecidas origens históricas), mas na
propriedade, no grande domínio rural que não podia subsistir sem a
escravidão e vice-versa. A abolição da escravidão não introduziu o
princípio da igualdade nas relações sociais e econômicas. Ao contrário, a
dominação rural transportou-se para as cidades, passando a permear todas
as relações sociais, econômicas, políticas e culturais.

Amauri Mascaro do Nascimento informa que, em 1890, a capital federal tinha uma população de 522.000 habitantes em 1890 e "São Paulo, 65.000, cifra que, em 1900, atingiu 240.000. Em 1907 concentravam-se no Rio de Janeiro 30\% das indústrias nacionais, e em São Paulo, 16\%" 468 . Mas o aumento da população urbana e dos impactos do trabalho urbano (manufaturas e indústrias) não veio acompanhado de uma preocupação política em disciplinar as relações de trabalho, ausente, assim, qualquer tipo de fiscalização nesse período ${ }^{469}$. Dessa forma, conforme explica Marcelo Antonio Chaves, em sua tese de doutorado sobre a trajetória do Departamento Estadual do Trabalho de São Paulo e a mediação das relações de trabalho entre 1911 e 1937,

\footnotetext{
${ }^{465}$ PRADO JÚNIOR, Caio. op. cit., p. 202.

${ }^{466}$ Id., loc. cit.

${ }^{467}$ BENEVIDES, Maria Victoria Mesquita. op. cit., p. 194.

${ }^{468}$ NASCIMENTO, Amauri Mascaro. Curso de direito do trabalho. 20. ed. São Paulo: Saraiva, 2005. p. 61.

469 "Não era pequeno o número de oficinas e manufaturas de calçados, vestuário, móveis, tintas, fundições etc., geralmente mal instaladas em galpões ou fundos de armazéns e locais não alcançados por qualquer tipo de fiscalização". (Id., loc. cit.).
} 
a história da República Velha é marcada pela tênue interferência do Estado nas relações de trabalho, contrariamente ao intenso intervencionismo estatal desde a chamada Revolução de 1930, fato que não se pretende contrariar. No entanto, esse contraste faz com que os instrumentos estatais do pré-30 tenham a sua existência nublada, enfraquecida, desmatizada, e as suas expressões, sob a forma de instituições, apareçam como estágios 'embrionários' ou formadores de algo que se 'amadurece' até ganhar forma definitiva. ${ }^{470}$

Pela história da economia brasileira, prevalecendo os interesses econômicos na condução dos negócios e mantido um certo formalismo no campo do direito que acomodava tais interesses, o resultado foram regras que, embora pautadas por motivos de natureza econômica, geraram eficiência para grupos específicos, ou seja, não atenderam ao propósito geral da coletividade, além de não promoverem a equidade. Exemplo disso é o Departamento Estadual do Trabalho em São Paulo (DET). Marcelo Antonio Chaves lembra o papel do DET como

encarregado de lubrificar a máquina estatal para atender às necessidades de alocação da força de trabalho imigrante nos grandes cafezais paulistas, atendendo, assim, aos interesses da burguesia latifundiária cafeeira. Essa era a função explícita da Agência Oficial de Colocação, uma das repartições do DET de 1911 e que, não há dúvidas, era, de fato, voltada para atender às necessidades dos fazendeiros. ${ }^{471}$

As leis de proteção ao trabalhador que já existiam na época eram desconsideradas no plano fático, como exemplifica Azis Simão:

O mesmo Boletim do Departamento do Trabalho, em comentário a este fato [desrespeito à lei de proteção ao trabalhador], dizia que, apesar de proibido por lei federal de 1891, em São Paulo empregavam-se pessoas menores de idade na indústria do tabaco. $\mathrm{O}$ fato, pela gravidade que assumia, passou a ser objeto de regulamentação em 1911, embora essa se tornasse inoperante devido às condições em que se encontrava a indústria em crescimento e a inexistência de um serviço capaz de efetivá-la. ${ }^{472}$

Mas o reconhecimento do ponto de vista formal do trabalho livre alimenta a luta dos trabalhadores para consolidar tal liberdade no plano real. Ao contrário do ex-escravo, o

\footnotetext{
${ }^{470}$ CHAVES, Marcelo Antonio. A trajetória do Departamento Estadual do Trabalho de São Paulo e a mediação das relações de trabalho (1911 e 1937). 2009. Tese (Doutorado em História) - Universidade Estadual de Campinas, Campinas, 2009. p. 18.

${ }^{471}$ Id. Ibid., p. 21.

${ }^{472}$ SIMÃO, Azis. Sindicato e Estado: suas relações na formação do proletariado de São Paulo. São Paulo: Dominus Ed., 1966. p. 23.
} 
imigrante europeu ingressa no mercado de trabalho brasileiro consciente da sua condição de homem livre. Essa consciência de homem livre afronta a formação dos proprietários rurais, não habituados a lidar com a liberdade nas relações de trabalho ${ }^{473}$. Caio Prado Júnior destaca que esta situação influenciará na evolução da legislação brasileira, em especial no Estado de São Paulo, onde aportou o maior contingente de imigrantes europeus $^{474}$. É o caso da criação Departamento Estadual do Trabalho de São Paulo, por meio do Decreto n. 2.071, de 05.07.1911, de autoria de Albuquerque Lins ${ }^{475}$. Em 16 de outubro de 1918, é criado o Departamento Nacional do Trabalho e, em 15 de janeiro de 1919, por meio do Decreto n. 3.724, institui-se a legislação sobre acidentes de trabalho. O Decreto n. 16.027, de 30 de abril de 1923, criou o Conselho Nacional do Trabalho (CNT) e, em 19 de janeiro de 1928, o Decreto n. 18.074, delega poderes de fiscalização ao $\mathrm{CNT}^{476}$.

Diante disso, conclui-se que a chamada "questão social", como apontam Gilberto Bercovici e Luís Fernando Massonetto, não surge em 1930, uma vez que a Revolução promovida por Getúlio Vargas não inaugura a legislação trabalhista no Brasil. Lembram os autores, contudo, que é, a partir de 1930, que ocorre a aceleração e a sistematicidade das leis trabalhistas e a constitucionalização dos direitos trabalhistas ${ }^{477}$.

Ainda segundo Gilberto Bercovici e Luís Fernando Massonetto, a legislação trabalhista e a abertura do espaço político para os trabalhadores objetivaram a construção de uma base social forte para firmar o poder de um Estado nacional fraco, de maneira que as leis trabalhistas não visaram beneficiar a burguesia industrial ascendente ${ }^{478}$. Entretanto, Sérgio Buarque de Hollanda, em 1936, apontava para a invasão do fascismo no discurso político nacional, a partir de uma doutrina acomodatícia, avessa aos gestos de oposição que

\footnotetext{
${ }^{473}$ PRADO JÚNIOR, Caio. op. cit., p. 214. Caio Prado Júnior ainda relata que "no caso dos trabalhadores europeus, estes atritos chegaram mesmo a ter larga repercussão internacional, obrigando os governos de origem da imigração brasileira a intervirem em favor de seus nacionais. Será entre outros o caso da Itália, que neste período fornecia o maior contingente imigratório. Diante dos abusos praticados nas fazendas contra trabalhadores italianos, chegou-se a propor no Parlamento daquele país a proibição terminante da emigração para o Brasil; os cônsules aqui acreditados andavam constantemente às voltas com as reclamações de seus compatriotas maltratados nas fazendas". (Id. Ibid., p. 214).

${ }^{474}$ Id., loc. cit.

${ }^{475}$ CHAVES, Marcelo Antonio. op. cit., p. 321.

${ }^{476}$ Id., loc. cit.

${ }^{477}$ BERCOVICI, Gilberto; MASSONETTO, Luís Fernando. Breve história da incorporação dos direitos sociais nas constituições democráticas brasileiras. Revista do Departamento de Direito Trabalho e Seguridade Social da Faculdade de Direito da Universidade de São Paulo, São Paulo, v. 2, n. 3, p. 66-67, jan/jul. 2007.

${ }^{478}$ Id. Ibid., p. 70.
} 
não deixariam amplas margens às transigências ${ }^{479}$. No caso da legislação trabalhista, a "doutrina acomodatícia" fez-se presente na inspiração corporativista que envolveu a legislação trabalhista da era Vargas e correspondeu ao anseio de afastar do cenário social a ideia de conflito entre os atores sociais, em nome do discurso da segurança e progresso nacionais.

Enfim, não se pode afastar que o Direito do Trabalho é reflexo da política adotada sob a denominação de "economia dirigida". ${ }^{480}$ Isso não desqualifica os inúmeros avanços conquistados com a disciplina das relações de trabalho subordinado; ao contrário, aponta para a necessidade de tornar essa disciplina mais coerente com sua real e originária função: garantir a dignidade do trabalhador, como ser humano que é. E é a autonomia propedêutica atribuída ao Direito do Trabalho que permite refletir sobre as normas juslaboralistas, não apenas como direito favorável aos hipossuficientes, mas como um ramo da Ciência Jurídica, sistemicamente estruturado.

O trabalho digno deve ser concebido como ação, no sentido conferido por Hannah Arendt. A filósofa e pensadora política alemã distingue as atividades humanas em três: labor, trabalho e ação. As duas primeiras podem ser realizadas fora da sociedade dos homens; somente a ação é inimaginável fora do seio social. A explicação dada por Hannah Arendt é a de que o labor corresponde à manutenção do processo biológico do corpo humano; o trabalho, por sua vez, corresponde ao que a autora denomina "artificialismo da existência humana", ou seja, os artefatos humanos, os quais não têm relação direta com a manutenção do ciclo biológico da espécie. Seria a ação, segundo Hannah Arendt, a "única atividade que se exerce diretamente entre os homens sem a mediação das coisas ou da matéria" ${ }^{481}$.

Percebe-se que o trabalho a que Hannah Arendt se refere é a ação do homem sobre a matéria, ou seja, a transformação que o homem opera sobre os objetos naturais, dando origem a objetos artificiais, frutos do seu esforço ou da sua inteligência. Porém, a relação entre trabalhador e empregador, que se transformou e se consolidou ao longo da História, compreende a esfera da ação humana, uma vez que se dá a partir da relação entre os homens. A "ação humana das relações trabalhistas" é resultado de uma escolha, fundamentada por valores e normas.

\footnotetext{
${ }^{479}$ HOLLANDA, Sérgio Buarque. op. cit., p. 187.

${ }^{480}$ RIPERT, Georges. Aspectos jurídicos do capitalismo moderno. Campinas: Red Livros, 2002. p. 62.

${ }^{481}$ ARENDT, Hannah. op. cit., p. 15.
} 
Previamente analisou-se que o distanciamento entre ciência e ética coincide com um período de identificação do trabalhador como parte da engrenagem dos recursos técnicos. Essa realidade não está longe dos olhos do homem pós-moderno. As ideias, decantadas pelos Iluministas, compuseram um arcabouço de reflexão filosófica, mas não evitaram a exploração do homem pelo homem. Aliás, as ideias foram interpretadas e alcançaram os limites precisos desejáveis na nova ordem sócio-econômica, como exemplo, cita-se a igualdade considerada em seu aspecto formal.

Dessa forma, quando se estabelecem normas que visam à regulação das relações de trabalho, há de se perquirir qual o lugar que o homem ocupa no âmbito das relações de trabalho, muito antes de discutir a eficácia ou não de uma determinada norma jurídica em um determinado novo cenário sócio-econômico. Conforme se observa, há duas possibilidades descritas no contexto estrutural das relações de trabalho subordinado: a) se o trabalho for contemplado como mero objeto (referencial econômico-capitalista), o homem assume contornos reificados; b) se compreender que o trabalho é um valor humano, o homem receberá o status não apenas de trabalhador, mas de cidadão, com deveres e com direitos individuais assegurados.

A partir disso, a diferença entre uma ou outra opção reflete-se no formato e no conteúdo atribuídos às normas trabalhistas. A opção por conceber o trabalho como valor humano é imprescindível para sociedade. Em regra, enquanto a situação se mantém estável, as questões sociais e, portanto, imprimidas de carga axiológica e principiológica, não são contempladas pelos que detém a maior parcela de poder.

O momento da afirmação dos direitos sociais dos trabalhadores coincide com um momento de crise do capitalismo. O sistema capitalista passou por duas fases, descritas por Georges Ripert:

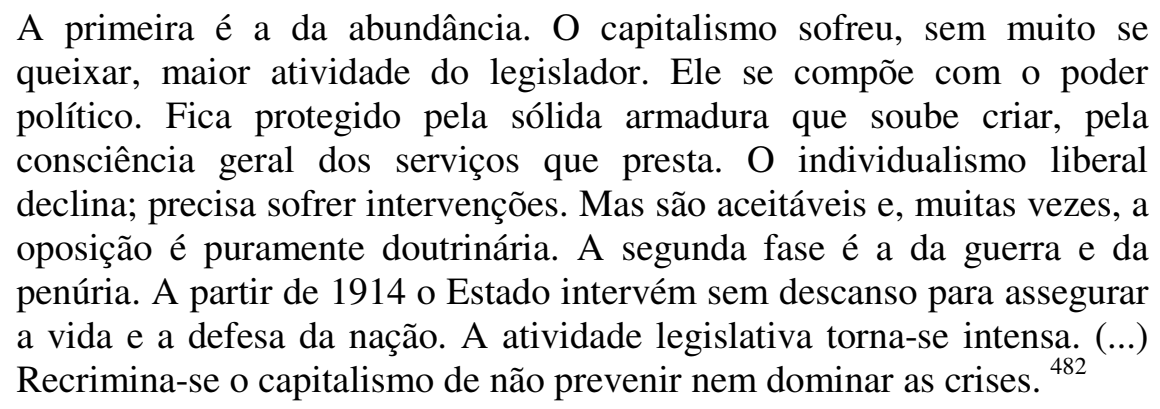

\footnotetext{
${ }^{482}$ RIPERT, Georges. op. cit., p. 36.
} 
A preocupação com a proteção específica das relações de trabalho aflora na segunda fase do sistema capitalista, ou seja, como um instrumento de superação de "crises". Poder-se-á indagar: a que crise se está referindo? Ripert refere-se às crises derivadas do próprio capitalismo, quando esse não era mais suficiente para satisfazer as necessidades, "seja por insuficiência da produção e do comércio, seja porque os preços não estão mais em conexão com os rendimentos e os salários". ${ }^{483}$ Quando o status quo sofre risco de ruptura, os interessados em sua manutenção direcionam os seus olhares para os insurgentes, em regra, com o propósito de neutralizar a força contrária aos seus interesses como grupo dominante.

O sistema econômico tornou-se proeminente e, embora tal fato não devesse comprometer os demais sistemas, a consequência foi a exposição de sistemas - como o juslaboral - à integração de elementos econômicos novos, sem suporte organizacional para adaptá-los, o que fragiliza a estrutura sistêmica. Historicamente recente, o discurso de flexibilização é um exemplo emblemático.

Em uma sociedade capitalista, o poder repousa nas mãos de quem detém o controle dos rumos da economia. E, conforme alertava Max Weber,

sabe-se que a preocupação com a 'segurança' econômica é, realmente de maneira consciente ou não - o ponto cardeal na orientação da vida de um homem que já possui fortuna. Não se detendo diante de nenhuma consideração de nenhum princípio, o idealismo político é praticado, se não exclusivamente ao menos principalmente, por indivíduos que, em razão da pobreza, estão à margem das camadas sociais interessadas na manutenção de certa ordem econômica em sociedade determinada. ${ }^{484}$

Frisa-se, contudo, que a força de trabalho não está dissociada do ser humano, de sorte que não é possível destacá-la do corpo humano; é o corpo que gera força de trabalho. Com base nessa premissa, no momento de se estabelecer normas que visam à regulação das relações de trabalho, há de se perquirir qual o lugar que o homem ocupa no âmbito das relações de trabalho. Se o trabalho for contemplado como mero objeto (referencial econômico-capitalista), o homem assume contornos reificados e até mesmo a saúde pode ser convertida em mercadoria, a exemplo do que ocorre com a adoção exclusiva dos mecanismos de compensação (tais como adicionais de insalubridade ou de periculosidade).

\footnotetext{
${ }^{483}$ RIPERT, Georges. op. cit., p. 61.

${ }^{484}$ WEBER, Max. Ciência e política: duas vocações, cit., p. 70.
} 
Enfim, o legislador, seja ele autônomo ou heterônomo, que identifica o trabalho como um fator de produção, não prioriza com a elaboração das normas maior prestígio a valores humanos, tais como proteção à vida, à saúde e à dignidade. Porém, se compreender o trabalho como um valor humano, o homem receberá o status não apenas de trabalhador, mas de cidadão, com deveres e com direitos individuais assegurados, dentre eles o respeito à vida e à saúde.

Fica claro, pois, que o valor humano do trabalho não resulta de um dado imposto pela ordem normativa ou um dado a priori, mas se trata de uma construção, cujo processo encontra-se em franco desenvolvimento.

\section{Uma análise sobre a dignidade e a monetarização (tarifação) da saúde e da vida do trabalhador}

Ao incorporar a dignidade no contexto das relações de trabalho subordinado, o sistema juslaboral rompeu com as fronteiras de sentido do discurso econômico, alheio às implicações de um sentido humano do trabalho. Entretanto, o sistema econômico sobrevive com sua coerência valorativa e segue provocando "irritações" no sistema jurídico:

A empresa - enquanto subsistema social do 'subsistema econômico - (...) opera em um código próprio: lucro/prejuízo, não lhe fazendo sentido salvo se houver repercussões econômicas - a licitude ou ilicitude de não recolher determinado tributo. (...) Como adverte Teubner, isso põe em causa a autoridade da validade jurídica enquanto tal e, por conseguinte, destrói a função do Direito enquanto meio de garantia de expectativas. ${ }^{485}$

A questão que se propõe a analisar é se o modelo juslaboral alicerçado na Consolidação das Leis do Trabalho mantém-se sob a base principiológica da Constituição Federal de 1988 ou se eventual anacronismo do texto consolidado permite a ruptura do sistema de disciplina do poder nas relações de trabalho subordinado. Para tanto, serão exploradas duas questões: a base de cálculo do adicional de insalubridade e a adoção da jornada de 12 X36.

\footnotetext{
${ }^{485}$ DANTAS, David Diniz. op. cit., p. 139-140.
} 


\subsection{O modelo de reparação/compensatório versus o valor da saúde e da vida do trabalhador para a sociedade: a questão da base de cálculo do adicional de insalubridade}

$\mathrm{Na}$ estrutura de poder das relações de trabalho subordinado, constata-se que o trabalhador - como indivíduo - é "irritado, influenciado e manipulado por diferentes racionalidades de comunicação, as quais são geradas pelos diferentes sistemas e subsistemas sociais, especialmente o sistema econômico e os subsistemas e regimes a ele conectados"486. A lógica do empregador e a contigencialidade das oscilações econômicas atingem a possibilidade de integração do ser humano e a esfera de liberdade interna do indivíduo.

A ausência de conceitos, de definições e a ampliação da discussão em torno da dignidade do trabalho permeada por vários discursos comprometem o sistema jurídico, que é instado à adaptação, mas pode sofrer irritação e fragilizar a sua organização. É o que ocorreu com a proposta de flexibilização e o exemplo do contrato a tempo parcial, banco de horas ou mesmo o contrato de trabalho por tempo determinado da Lei n. 9.601/1998.

Introduzem-se instrumentos ineficientes no que tange à promoção da dignidade humana, em nome de eficiência econômica e, no contexto sistêmico, os efeitos são danosos para toda a coletividade. Extrai-se, no processo dinâmico das relações de trabalho subordinado, o dissenso.

Para Celso Campilongo, a partir da teoria luhmanniana reconhece-se a legitimidade do dissenso, pois Niklas Luhmann procurou, em sua teoria, escapar da idealização de um consenso democrático, com base em noções como paz e bem comum. Não se discute que essas noções constituem valores com capacidade de agregar a sociedade, pois tem a função de criar uma base para a comunicação. Mas seria a legitimidade do dissenso contrário à democracia? Diante dessa questão, fundado no pensamento de Luhmann, Campilongo propõe outra indagação: “A função do sistema jurídico é garantir o consenso e fundar moralmente o ordenamento jurídico ou, ao contrário, é assegurar ao direito a capacidade de manter elevada a complexidade social e conferir às decisões judiciais uma adequada

\footnotetext{
${ }^{486}$ DE VINCENZO, Brunela Vieira de. op. cit., p. 116.
} 
consistência em relação às expectativas normativas?"487 A resposta é induzida pela teoria dos sistemas autorreferenciais. O conceito de dignidade é um construído, a partir de um dado referencial. Assim, é possível que cada sistema adote uma noção diferente de dignidade, a exemplo de bem comum: "para uns, o 'bem comum' pode significar a ampla participação na vida pública, para outros pode representar a não interferência na vida privada" 488 .

Então, há várias racionalidades e o mais importante é reconhecer a lógica do discurso subjacente e a sua conformação com a proposta constitucional de promoção da dignidade do trabalhador. O Direito, dessa maneira, deve assumir a sua função de criar condições de emergência de cooperação entre os agentes, traduzida aqui na forma de contenção da colisão de discursos, com violação das condições dignas de trabalho.

O que se propõe aqui não é analisar o Direito com base no referencial econômico, mas eventualmente analisar os reflexos econômicos com base nos institutos jurídicos que regulam as relações de trabalho subordinado.

A análise econômica do Direito, portanto, não está alheia ao sistema jurídico, conforme destacou Gunther Teubner. ${ }^{489}$ O problema é adotar o sistema econômico como “deus único" e não compreender a complexidade da sociedade. Por exemplo, a análise dos custos pode resultar em desrespeito a direitos fundamentais, como o direito à vida e à saúde, na hipótese de o trabalhador transacionar o valor de sua vida e da sua saúde em troca de compensação financeira. Essas hipóteses denotam a ineficiência do modelo de incentivo de conduta, que envolve as atividades legislativa, administrativa e jurisdicional.

O que se constata, portanto, é que a teoria econômica da escolha racional não pode se arvorar na condição de dogma, como uma "religião" a ser seguida. Gunther Teubner ressalta que

Hoje o único Deus existente para o qual se admite que o Direito faça sacrifícios é a chamada escolha racional. Nos últimos trinta anos, o quase-religioso movimento se espalhou por todas as escolas de Direito da América do Norte com um particular entusiasmo. Depois do seu maior pastor - Richard Posner anunciou "a morte do direito como uma disciplina autônoma" - a racionalidade econômica se apresenta como a nova universalidade do Direito. Teoria dos custos de transação, teoria dos direitos de propriedade, escolha pública e a análise econômica do direito

\footnotetext{
${ }^{487}$ CAMPILONGO, Celso. Política, sistema jurídico e decisão judicial, cit., p. 125-126.

${ }^{488}$ Id. Ibid., p. 125.

${ }^{489}$ TEUBNER, Gunther. Altera pars auditur: law in collision of discourses, cit., p. 172.
} 
são diferentes correntes no largo curso de um movimento que pretende substituir o débil conceito de justiça com o ideal de eficiência econômica do Direito. ${ }^{490}$

Indagar sobre a racionalidade econômica, portanto, é indispensável. A teoria econômica baseia-se no seguinte comportamento do empregador: "Um empregador determinará se vai prevenir as doenças ou acidentes no local de trabalho comparando o custo da prevenção com o custo de não adotar a conduta preventiva". ${ }^{491}$ Com base nessa premissa, há, portanto, de se perquirir sobre o impacto dos direitos fundamentais sociais na dinâmica das relações de trabalho subordinado. Vale, então, considerar o modelo de reparação/compensação concebido na esfera das relações privadas, em face do reconhecimento constitucional de preservação da vida e saúde do ser humano. Para tanto, enuncia-se o exemplo da discussão sobre a base de cálculo do adicional de insalubridade.

O legislador infraconstitucional determinou que a base para cálculo do adicional de insalubridade é o salário-mínimo (artigo 192, caput, da CLT). Isso significa que um trabalhador, que perceba uma remuneração de mil e quinhentos reais e está exposto a um grau máximo de insalubridade, irá receber a título de adicional de insalubridade o valor de duzentos e dez reais. ${ }^{492}$ Essa medida compensatória não impulsiona a estrutura das relações de trabalho subordinado para o propósito de efetivar a dignidade do trabalhador.

O empregador vai adotar medidas de redução de riscos até o ponto de ser menos custoso pagar aos trabalhadores o adicional sobre a remuneração do que investir na implementação de prevenção contra riscos à saúde e à segurança do trabalhador. $\mathrm{Na}$ hipótese do custo mensal com a manutenção e fiscalização do uso do EPI, que elimina o risco da insalubridade, ser superior ao valor da compensação - no exemplo proposto, de cento e oitenta reais -, será para ele mais interessante compensar o trabalhador do que adotar medidas de eliminação ou neutralização do risco.

No entanto, quanto à base de cálculo do adicional de insalubridade, a redação do artigo 192, caput, da CLT é anterior à Constituição Brasileira de 1988. Iniciou-se, então, um debate sobre a recepção ou não do artigo pela nova Carta Constitucional, em face do seu artigo $7^{\circ}$, inciso IV, in verbis:

\footnotetext{
${ }^{490}$ TEUBNER, Gunther. Altera pars auditur: law in collision of discourses, cit., p. 149.

${ }^{491}$ SHAPIRO, Sidney A. op. cit., p. 598.

${ }^{492}$ Conforme o valor do salário mínimo fixado em $\mathrm{R} \$ 510,00$ (quinhentos e dez reais) pela Medida Provisória $\mathrm{n}^{\circ} 474$, de 23 de dezembro de 2009.
} 
Art. $7^{\circ}$ São direitos dos trabalhadores urbanos e rurais, além de outros que visem à melhoria de sua condição social:

$[\ldots]$

IV - salário-mínimo, fixado em lei, nacionalmente unificado, capaz de atender a suas necessidades vitais básicas e às de sua família com moradia, alimentação, educação, saúde, lazer, vestuário, higiene, transporte e previdência social, com reajustes periódicos que lhe preservem o poder aquisitivo, sendo vedada sua vinculação para qualquer fim. ${ }^{493}$

A leitura do texto constitucional não deixa dúvidas acerca da voluntas legislatoris, ou seja, impedir que o salário-mínimo seja base de referência ou de cálculo para qualquer $\underline{\text { fim. }}$

Levada a questão ao Tribunal Superior do Trabalho, seu entendimento foi reproduzido em duas Súmulas: a 228 e a 17. Inicia-se com a Súmula 228 que estabelece uma regra geral:

228. Adicional de insalubridade. Base de cálculo.

O percentual do adicional de insalubridade incide sobre o salário mínimo de que cogita o art. 76 da CLT, salvo as hipóteses previstas no Enunciado 17.

17. Adicional de insalubridade

$\mathrm{O}$ adicional de insalubridade devido a empregado que, por força de lei, convenção coletiva ou sentença normativa, percebe salário profissional será sobre este calculado.

No presente estudo, não cabe discorrer sobre o impacto hermenêutico das súmulas acima, como, por exemplo, o debate sobre qual a extensão da expressão "salário profissional". Urge destacar que o TST manteve a base de cálculo fixada pelo legislador infraconstitucional, isto é, o salário-mínimo, admitindo apenas uma exceção à regra geral.

Debateu-se a matéria no Superior Tribunal Federal (STF), o qual, até abril de 2008, não havia firmado posição pacífica sobre o tema. A Primeira Turma do STF optava por decidir pela inconstitucionalidade da adoção do salário-mínimo como base de cálculo de

\footnotetext{
${ }^{493}$ BRASIL. Constituição da República Federativa do Brasil: promulgada em 5 de outubro de 1988. Contém as emendas constitucionais posteriores. Brasília, DF: Senado, 1988.
} 
adicional de insalubridade ${ }^{494}$, enquanto a Segunda Turma inclinava-se para o posicionamento contrário. ${ }^{495}$

Vale citar os argumentos que levaram a decisões díspares na Suprema Corte Nacional. No Recurso Extraordinário (RE) n. 236.396, em decisão unânime, deu provimento ao recurso nos termos do voto do Ministro Sepúlveda Pertence. Em seu voto, o Ministro relator identificou a contrariedade ao artigo $7^{\circ}$, inciso IV da Constituição da República, quando o TST fixou o adicional de insalubridade em determinado percentual do salário-mínimo, incabível desde a promulgação da Constituição, remetendo os autos ao Tribunal Regional do Trabalho (TRT) de origem para decidir qual o critério substitutivo aplicável.

Na Arguição de Descumprimento de Preceito Fundamental (ADPF) n. 95, de 31.08.2006, prevaleceu o entendimento de que o artigo $7^{\circ}$, inciso IV, da Constituição Brasileira de 1988, não impediu a utilização do salário-mínimo como parâmetro quantificador para cálculo de indenização.

Posteriormente, em decisão proferida em 11.12.2007, a Segunda Turma, também em decisão unânime, acolheu o voto do relator, Ministro Gilmar Mendes, no RE n. 439035, afastando a vinculação do salário-mínimo. O Ministro Gilmar Mendes menciona posicionamento adotado pela Primeira Turma e o acolhe em sua decisão, dado que o artigo $7^{\circ}$, inciso IV da CLT veda a vinculação do salário-mínimo para qualquer fim. Ressalta-se que o Relator determina a remessa dos autos ao TRT de origem para que esse restabeleça o critério utilizado, qual seja, adoção da remuneração como base de cálculo do adicional de insalubridade. Ao proclamar o seu voto, o Ministro Eros Grau afirmou a superação do entendimento anterior preconizado pela Segunda Turma e reproduzido no acórdão do RE n. 458.802 .

Essa discussão retrata propriamente o que enunciou Richard A. Posner, cuja citação ousa-se novamente reproduzir:

os casos litigados de acordo com regras ineficientes tendem a colocar mais coisas em jogo do que os casos litigados de acordo com regras eficientes porque as regras ineficientes, por definição, geram desperdício social, e quanto mais coisas estiverem em jogo numa disputa, tanto mais provável que esta seja litigada, ou seja, que não se chegue a um acordo;

\footnotetext{
${ }^{494}$ Ver RE 236.396; RE-AgR 451220; RE 451215 AgR; RE 487751 AgR.

${ }^{495}$ Ver AI-AgR 177959; RE 340.275; RE-AgR 561378; RE 458.802.
} 
assim, os juízes terão uma possibilidade de reconsiderar a regra ineficiente. ${ }^{496}$

Ao STF foi atribuída a responsabilidade para reconsiderar a regra ineficiente e, em Sessão Plenária de 30.04.2008, aprovou a Súmula Vinculante n. 4:

Súmula Vinculante 4

Salvo nos casos previstos na Constituição, o salário-mínimo não pode ser usado como indexador de base de cálculo de vantagem de servidor público ou de empregado, nem ser substituído por decisão judicial.

Uma breve análise regressiva dos argumentos do STF sobre a matéria, até a aprovação da Súmula Vinculante n. 4, permite concluir que o argumento favorável à não recepção do artigo 192 da CLT está atrelado à interpretação literal do artigo 7º inciso IV, parte final, da Constituição Federal de 1988; por outro lado, o argumento então esposado pela Segunda Turma do STF, embora pautada em uma interpretação literal, inclui conceitos que não se extraem da norma constitucional, mas parece avaliar os impactos econômicos, ou seja, tentam se aproximar de uma análise econômico-normativa. Alguns termos extraídos dos julgados citados, como "indexação" e "inflacionamento", justificam a decisão que sustenta a adoção do salário-mínimo como base de cálculo do adicional. Mas aqui cabe uma ponderação: com base nos custos sociais decorrentes de acidentes de trabalho já apresentados, uma análise econômico-normativa não deveria estar voltada para os impactos no comportamento do empregador no âmbito da relação de trabalho, partindo da premissa de que a conduta a ser incentivada é a eliminação ou neutralização dos riscos à vida e à saúde do trabalhador?

O que se observa do conteúdo da Súmula Vinculante 4 é uma conclamação implícita para que o legislador infraconstitucional estabeleça os parâmetros para cálculo do adicional de insalubridade, conforme os ditames e os limites constitucionais. O STF objetivou retirar dos órgãos judiciários a atribuição de legislar sobre a matéria, pois:

Art. $7^{\circ}$ São direitos dos trabalhadores urbanos e rurais, além de outros que visem à melhoria de sua condição social:

\section{$[\ldots]$}

XXIII - adicional de remuneração para as atividades penosas, insalubres ou perigosas, na forma da lei.

\footnotetext{
${ }^{496}$ POSNER, Richard A. op. cit., p. 484.
} 
Enquanto não disciplinada infraconstitucionalmente, qual critério será utilizado, diante do texto da Súmula Vinculante n. 4? Situações desse jaez demonstram a fragilidade, a inconsistência, ou quiçá, a ausência de premissas sólidas de um modelo jurídico de incentivo de condutas, pois, no cenário atual, pode-se mesmo sustentar que a previsão do adicional de insalubridade, na ausência de norma regulamentadora, não produz efeitos jurídicos. A consequência disso, do ponto de vista técnico-jurídico positivo, é a ausência de obrigatoriedade de compensar os riscos decorrentes do ambiente de trabalho insalubre, até que o legislador se pronuncie sobre os parâmetros para aplicação da norma constitucional.

Cumpre mencionar que, no julgamento do recurso extraordinário com repercussão geral (RE n. 565.714), a partir do qual se aprovou a referida Súmula Vinculante, a Confederação Nacional das Indústrias destacou o aumento dos custos que uma decisão contrária à vinculação do salário-mínimo ensejaria, isto é, precisamente provocaria um aumento no "passivo" das empresas. O Governo do Estado de São Paulo alegou que, no caso de o STF entender que a vinculação ao salário-mínimo ofende o artigo $7^{\circ}$, inciso IV da Constituição Brasileira, haveria de se entender que, na ausência de norma infraconstitucional vigente, $\underline{o}$ direito ao adicional de insalubridade seria inexigível. Ressaltou o Governo do Estado de São Paulo que se manteria o pagamento do adicional vinculado ao salário-mínimo, dada a falta de norma regulamentadora em sentido contrário. $^{497}$ Tal entendimento foge à coerência do sistema jurídico, ao promover o desestímulo à preservação da saúde e da segurança do meio ambiente do trabalho.

Outra norma jurídica que não induz ao padrão devido - eliminação ou neutralização dos riscos de acidentes do trabalho - é a impossibilidade de acumulação de adicionais de periculosidade e insalubridade, decorrente do $\S 2^{\circ}$ do artigo 193 da CLT. O trabalhador que é exposto, por exemplo, a agentes químicos (insalubridade) e a agentes ionizantes (periculosidade) somente pode receber $\underline{\mathrm{um}}$ dos adicionais previstos na lei. Focando na estrutura da norma, repousa subentendida a preocupação de redução de custos imediatos de produção: se o meio ambiente desfavorável à saúde do trabalhador é decorrente da atividade econômica desenvolvida, que seja pago um adicional, porém tão somente um. Qual o incentivo para o empregador eliminar ou neutralizar a insalubridade, se o trabalhador preferir o adicional de periculosidade e não houver a obrigação do empregador de compensar o risco com a insalubridade? Essa lógica, como se verifica, não considera os

${ }^{497}$ TV
<http://videos.tvjustica.gov.br/?video=1301>. Acesso em: 16 jun. 2008.


custos sociais decorrentes a médio e longo prazos e acabam por gerar consequências desastrosas e ineficientes.

\subsection{O risco da ineficiência das medidas compensatórias}

De acordo com os dados da publicação do Ministério do Trabalho e Emprego mencionada, em 2003, os gastos da Previdência Social com pagamento de benefícios acidentários e aposentadoria especial totalizaram cerca de 8,2 bilhões de reais:

Segundo Pastore (1998), para cada real gasto com o pagamento de
benefícios previdenciários, a sociedade paga quatro reais, incluindo
gastos com saúde, horas de trabalho perdidas, reabilitação profissional,
custos administrativos etc. Esse cálculo eleva a um custo total para o país
de aproximadamente 33 bilhões de reais por ano. [...] O número de dias
de trabalho perdidos em razão dos acidentes aumenta o custo da mão de
obra no Brasil, encarecendo a produção e reduzindo a competitividade do
país no mercado externo. Estima-se que o tempo de trabalho perdido
anualmente devido aos acidentes de trabalho seja de 106 milhões de dias,
apenas no mercado formal, considerando-se os períodos de afastamento
de cada trabalhador. ${ }^{498}$

O Direito objetiva evitar quadros de ineficiência, ou seja, conter as falhas decorrentes das relações entre os particulares, como o relatado acima. Observa-se que a opção pela proteção da vida e da saúde do trabalhador é uma escolha social maximizadora de "riqueza", isto é, uma escolha racional. A elaboração de normas de incentivo de conduta deve priorizar a prevenção da ocorrência dos danos. Mas um dos incentivos de conduta são os mecanismos de efetividade (enforcement), que geram custos. Para o Estado Brasileiro, a Justiça do Trabalho constitui um exemplo de custos que o Estado assume para assegurar a efetividade de direitos sociais. Além da Justiça Especializada, o Poder Executivo mantém todo um aparato burocrático voltado à fiscalização de irregularidades no campo do trabalho subordinado. Ou seja, o Estado arca com custos para garantir que os demais custos decorrentes do cumprimento da legislação trabalhista sejam devidamente pagos pelo empregador, para evitar outros maiores custos sociais futuros. O custo variará conforme o

\footnotetext{
${ }^{498}$ BRASIL. MINISTÉRIO DO TRABALHO E EMPREGO. Política Nacional de Segurança e Saúde do Trabalhador: Proposta para Consulta Pública - versão pronta após sugestões - 29.12.2004, cit., p. 8.
} 
grau de proteção conferido pelo ordenamento jurídico, o que culmina em uma obviedade: quanto maior a proteção, maior o custo.

Na óptica do sistema econômico capitalista, os custos determinam o valor da mercadoria. O valor do trabalho, como fator de produção, influencia o preço final da mercadoria produzida. Sob essa perspectiva, o capitalista tenta reduzir ao máximo o custo da produção ou para tornar o preço da mercadoria atrativo ao consumidor ou para aumentar sua margem de lucro. Conforme foi citado no início do tópico anterior, os empregadores adotarão medidas de redução de riscos até o ponto de ser menos custoso pagar aos trabalhadores o adicional sobre a remuneração do que investir na implementação de prevenção contra riscos à saúde e à segurança do trabalhador. ${ }^{499}$

Dada a postura do empregador, há de avaliar as implicações jurídicas, em face do conteúdo econômico presente nas relações de trabalho subordinado. Um dos princípios basilares do Direito do Trabalho é o princípio da norma mais favorável, o qual decorre da constatação de que, nas relações de trabalho subordinado, não há igualdade material entre as partes. Ainda que o sistema jurídico reconheça que a subordinação é decorrência imediata e direta do contrato de trabalho e não se confunde com subordinação econômica, na dinâmica da relação entre empregado e empregador, a "desigualdade jurídica material" traduz-se em assimetria de informação, responsável pela origem de três tipos de problemas: a) seleção adversa; b) risco moral (moral hazard); e c) contratos incompletos. E esses problemas, embora sejam avaliados sob uma perspectiva econômica, são traduzidos pelo sistema jurídico.

\subsubsection{Seleção adversa (informação escondida)}

Uma vez estabelecido o contrato, o agente pode se aproveitar da assimetria de informação e descumprir o acordado. Por exemplo, no contrato de trabalho, o empregador sabe avaliar melhor os riscos que a atividade econômica que ele explora geram à saúde e à vida do trabalhador, e será de seu interesse compensar o trabalhador com um valor inferior ao risco. Daí o legislador fixar o valor da compensação, a exemplo da insalubridade, de modo gradativo: riscos máximo, médio e mínimo.

\footnotetext{
${ }^{499}$ SHAPIRO, Sidney A. op. cit., p. 596.
} 


\subsubsection{Risco moral (moral hazard)}

Quando há segurança de que o dano será indenizado, o agente se preocupará menos (redução do cuidado) em evitá-lo, aumentando a probabilidade de sua ocorrência. No exemplo do contrato de trabalho, uma vez que fique definida a responsabilidade objetiva do empregador em ressarcir os danos causados em acidente do trabalho, o trabalhador (vítima) não terá incentivo em se esforçar por manter o cuidado devido para evitar acidentes de trabalho ou doenças profissionais.

\subsubsection{Contratos incompletos}

Dos três problemas apresentados, os contratos incompletos assumem relevância dentro do Direito do Trabalho porque evocam um dos seus princípios basilares: o princípio da norma mais favorável. Dada a desigualdade entre os agentes econômicos, os contratos tendem a prestigiar os interesses de uma das partes em desvantagem da outra. Ademais, o cenário inicial em que o contrato foi celebrado pode sofrer alterações. A tendência do legislador é interpretar a norma com vistas a buscar o interesse da parte hipossuficiente (com menos informação). No sistema juslaboral, o princípio da norma mais favorável assume essa função.

É possível afirmar que o contrato de trabalho subordinado, originário dos séculos XVIII e XIX, constitui um exemplo dos atuais contratos de adesão. A principal característica dos contratos de adesão é a assimetria de poder, ou seja, desigualdade, o que pressupõe a hipossuficiência de uma parte perante a outra no momento da tomada de decisão ou, melhor dizendo, no momento do exercício da autonomia da vontade (liberdade). Armando Castelar Pinheiro e Jairo Saddi chegam a concluir que o próprio direito do consumidor é mais um direito do trabalhador. Para os dois autores, como "a grande parcela de consumidores é constituída, portanto, de agentes econômicos que são também trabalhadores assalariados das mais diversas áreas", na medida em "que eram 
percebidos avanços nos direitos humanos, ao trabalhador, principalmente, eram asseguradas novas conquistas" ${ }^{500}$, como os direitos do consumidor.

Enfim, a tutela do trabalhador e o sistema de defesa do consumidor surgem da constatação de que, nas relações de trabalho e de consumo, os agentes envolvidos detêm informação assimétrica. Por conseguinte, no caso de discussão sobre o alcance e o sentido de uma cláusula contratual, o princípio da norma mais favorável visa a uma interpretação que reproduza o interesse da parte hipossuficiente e restabeleça seus direitos eventualmente infringidos. A aplicação do princípio da norma mais favorável, nessa perspectiva, traduz-se por um instrumento de restabelecimento de equilíbrio, do incentivo ao padrão devido e, portanto, da maximização de "riqueza". Contudo, Marcelo Batuíra da C. Losso Pedroso, ao propor uma análise econômica do Direito do Trabalho, concluiu que:

se o aplicador do direito pender para o trabalhador, na solução de um litígio, com base na validade desse critério hermenêutico [in dubio pro operario], estará fazendo com que o interesse do particular (do empregado) prevaleça sobre o bem comum, que é representado pela empresa que constitui a fonte de sobrevivência de vários outros trabalhadores. ${ }^{501}$

O bem comum ou a "riqueza" de uma sociedade, de acordo com o ordenamento vigente, é representado pelas escolhas (preferências) sociais destacadas da Constituição Federal, dentre elas a garantia da dignidade humana. Associar o bem comum à figura da empresa, como fonte de sobrevivência de outros trabalhadores, sem atentar para a garantia da vida e da saúde do ser humano, pode levar a situações de exploração da mão-de-obra justificada pelos interesses exclusivos da parte com mais informação. Além disso, constitui o risco de assumir uma postura institucionalista, encontrada nos regimes autoritários, os quais primavam pela negação de uma sociedade pluralista. Considere-se o caso julgado pela Quarta Turma do Tribunal Superior do Trabalho (TST), no Recurso de Revista (RR) n 660481.2000.0. A empresa American Bank Note Company Gráfica e Serviços Ltda. foi condenada ao pagamento de indenização por obrigar um empregado a ficar nu em corredor espelhado para fazer revista visual. Condenada em primeira instância, a empresa, contudo, havia sido absolvida pelo Tribunal Regional do Trabalho da $1^{\text {a }}$ Região (TRT/RJ). O TRT/RJ considerou a revista de empregados lícita. As circunstâncias, segundo o

\footnotetext{
${ }^{500}$ PINHEIRO, Armando Castelar; SADDI, Jairo. op. cit., p. 397.

${ }^{501}$ PEDROSO, Marcelo Batuíra da C. Losso. op. cit., p. 157.
} 
entendimento do TRT/RJ, justificaram a revista, pois a empresa produzia material impresso para o qual a segurança é indispensável, por envolver o direito dos usuários dos serviços prestados. Além disso, o órgão de segunda instância levou em consideração, como justificativa para a revista, a notícia-crime registrada pela empresa em delegacia de polícia sobre a ocorrência de furtos do material confeccionado na gráfica. A revista era realizada na saída do prédio, momento em que "os empregados da American Bank Note eram obrigados ficar nus em um compartimento. Depois, entravam num corredor de um metro de largura por 3,5 metros de comprimento, todo espelhado, para fazer o percurso de ida e volta. Do lado de fora, eram observados pelos funcionários encarregados da revista visual." ${ }^{, 502}$ A submissão à nudez, entendeu o TRT/RJ, seria a única forma de a empresa realizar uma revista eficaz, dado que os produtos comercializados pela empresa seriam de pequeno tamanho e ínfimo volume. Dessa maneira, o TRT/RJ não analisou as consequências (risco de danos psicológicos e, portanto, comprometimento à saúde) em razão da constante exposição do trabalhador à nudez nessas condições. Na decisão do TST, que restabelece a condenação da empresa, buscou-se resgatar a dignidade do ser humanotrabalhador: "A fiscalização deve dar-se (...) mediante métodos razoáveis, de modo a não expor o empregado a uma situação vexatória e humilhante, não expô-lo ao ridículo nem à violação de sua intimidade". 503

É inquestionável que há decisões judiciais ineficientes, tanto do ponto de vista jurídico, como econômico-social. Richard A. Posner ressalta, entretanto, que tais decisões, por definição, vão impor custos sociais maiores do que aqueles impostos por decisões eficientes; o resultado é que "os que perdem os casos erradamente decididos de um ponto de vista econômico terão um incentivo maior, em termos gerais, a pressionar por correção mediante recurso, por um novo processo ou por ação legislativa, do que os que perderem os casos judiciosamente decididos de um ponto de vista econômico". 504 Ademais, prossegue Richard A. Posner,

os casos litigados de acordo com regras ineficientes tendem a colocar mais coisas em jogo do que os casos litigados de acordo com regras eficientes (porque as regras ineficientes, por definição, geram desperdício social, e quanto mais coisas estiverem em jogo numa disputa, tanto mais provável que esta seja litigada, ou seja, que não se chegue a um acordo;

\footnotetext{
${ }^{502}$ NOTÍCIAS DO TRIBUNAL SUPERIOR DO TRABALHO. Disponível em: $<$ http://ext02.tst.gov.br/pls/no01/no_noticias.Exibe_Noticia?p_cod_noticia=4581\&p_cod_area_noticia=AS CS>. Acesso em: 23 jul. 2008.

${ }^{503}$ Id., loc. cit.

${ }^{504}$ POSNER, Richard A. op. cit., p. 483-484.
} 
assim, os juízes terão uma possibilidade de reconsiderar a regra ineficiente. ${ }^{505}$

O fundamento da decisão depende da concepção de trabalho adotada. Em se tratanto de relações de trabalho subordinado, de acordo com o que já foi abordado, deve-se conceber o trabalho como uma ação humana, resultado de uma escolha, fundamentada por valores e normas. Por isso, não é possível pensar em trabalho sem liberdade. Disso decorre que a ideia de trabalho digno depende de um quadro de liberdade para o trabalhador expressar-se como ser humano em todo o seu potencial. O reconhecimento dos direitos fundamentais do trabalhador visou, dessa maneira, à proteção da integridade do trabalhador, em respeito à sua condição humana. Discutir-se-ia, então, como são concebidos os direitos nesse novo contexto que abarca os direitos humanos.

Stephen Holmes e Cass R. Sunstein lembram que a concepção de direitos depende do enfoque do sujeito-observador. Como exemplo, os autores trazem o direito a não poluição. Para eles, o teórico da moral no direito deverá dizer, em abstrato, que não existe direito de poluir. Por outro lado, o positivista sabe, com base na jurisprudência norteamericana, o dono das terras rio acima pode adquirir o direito de poluir do proprietário das terras situadas no desaguadouro do rio. ${ }^{506} \mathrm{E}$ a questão que se põe é: qual dos dois paradigmas deve ser adotado? Ou ainda: é possível apontar a existência de um paradigma único? A resposta está na organização do sistema jurídico e a função a que ele se destina.

\subsection{O excesso de comunicação no sistema jurídico: o modelo da responsabilidade subjetiva do empregador por acidentes de trabalho à luz do Código Civil de 2002}

A conclusão a que chegou o Ministério do Trabalho e Emprego em publicação já citada nesse estudo é de que o "atual sistema de segurança e saúde do trabalhador carece de mecanismos que incentivem medidas de prevenção, responsabilizem os empregadores, propiciem o efetivo reconhecimento dos direitos do segurado, diminuam a existência de

\footnotetext{
${ }^{505}$ POSNER, Richard A. op. cit., p. 484.

${ }^{506}$ HOLMES, Stephen; SUNSTEIN, Cass R. op. cit., p. 18.
} 
conflitos institucionais, tarifem de maneira mais adequada as empresas e possibilitem um melhor gerenciamento dos fatores de riscos ocupacionais". 507

De fato, a própria previsão de compensação financeira ineficiente pelo risco à saúde do trabalhador decorrente do meio ambiente do trabalho já constitui uma adequação a interesses de grupos com maior poder de barganha e não à maximização da utilidade coletiva: proteção da vida e da saúde. Ao menos, em princípio, poder-se-ia imaginar que uma base de cálculo maior impulsionaria o empregador, em sua óptica de lucro-prejuízo, à adoção de medidas de redução e eliminação de riscos no meio ambiente do trabalho.

Contudo, a premissa "os empregadores adotarão medidas de redução de riscos até o ponto de ser menos custoso pagar aos trabalhadores o adicional sobre a remuneração do que investir na implementação de prevenção contra riscos à saúde e à segurança do trabalhador" revela que o aumento da compensação não gera necessariamente incentivo de conduta conforme o padrão devido. Giovanni Immordino e Marco Pagano ressaltam que “ao aumentar o custo de produção para as empresas, padrões mais rígidos aumentam o incentivo para o descumprimento e, portanto, exigem medidas de coerção mais intensivas ${ }^{\circ 08}$.

Sidney A. Shapiro conclui que "mesmo se mais trabalhadores fossem compensados com índices de compensação mais altos, os empregadores poderiam ainda ter falta de um forte incentivo econômico para investir em medidas de saúde. A decisão de um administrador em investir em prevenção de doenças não está baseada na compensação dos gastos, a qual resulta das ações passadas, mas na probabilidade de que o investimento prevenirá doenças futuras". ${ }^{509}$ Como as doenças profissionais são resultados de longa exposição, as consequências da conduta não são verificadas prontamente. Mais que isso, Sidney A. Shapiro avalia que "os administradores sabem que muitos trabalhadores mudarão de emprego durante o longo período de latência (dos efeitos da doença), o que livra o empregador do pagamento da compensação quando o trabalhador vier a adoecer" 510

\footnotetext{
${ }^{507}$ BRASIL. MINISTÉRIO DO TRABALHO E EMPREGO. Política Nacional de Segurança e Saúde do Trabalhador: Proposta para Consulta Pública - versão pronta após sugestões - 29.12.2004, cit., p. 8.

${ }^{508}$ IMMORDINO, Giovanni; PAGANO, Marco. The costs of rights - an economic analysis. Diritto \& Questioni Pubbliche, Palermo, n. 4, p. 88, ano 2004.

${ }^{509}$ SHAPIRO, Sidney A. op. cit., p. 607.

${ }^{510}$ Id., loc. cit.
} 
O resultado é que as medidas de compensação, tais como adicionais sobre a remuneração, não são eficientes por si só, ainda que as regras fossem bem elaboradas. Tomadas isoladamente, as medidas de compensação remuneratórias não incentivam condutas de eliminação ou neutralização de riscos à saúde ou à vida dos trabalhadores.

A tendência é que as medidas de coerção indireta cedam espaço paulatinamente a medidas de coerção direta ou o estímulo à busca de indenização pelas vias judiciais. Para isso, o modelo deve considerar a conjugação de medidas compensatórias elaboradas de maneira eficiente a um modelo de responsabilidade civil que incentive a conduta de acordo com o padrão devido. Muitas vezes a aplicação da legislação resulta em esforços paliativos, quando se propõem medidas compensatórias ineficientes para atender a grupos de interesses econômicos com maior poder de barganha.

O custo da compensação aumenta ou é devidamente calculado em função da informação do risco da atividade de que detém o trabalhador. Quanto mais ele sabe que a atividade por ele realizada provoca risco, maior será a sua demanda por compensação. Ocorre que o risco não é individual, mas de uma coletividade de trabalhadores. Dessa forma, o cálculo do risco é coletivo e não individual; depende, pois, da organização do grupo de trabalhadores envolvidos para pressionar o empregador à negociação.

Isso significa que o adicional compensatório que um trabalhador pode obter em razão da exposição a riscos do ambiente de trabalho é uma função do poder de negociação do trabalhador. ${ }^{511}$ Dada a dificuldade de integração dos trabalhadores no ambiente de trabalho, a figura do sindicato torna-se determinante para o exercício do processo de barganha e disseminação da informação. No entanto, no Brasil, o sistema de unicidade sindical, com contribuição sindical compulsória, garante o "monopólio" da representação e não exige do sindicato uma atuação competitiva em busca da maior representatividade. $\mathrm{O}$ resultado é a reduzida integração entre sindicatos e trabalhadores, que permanecem, assim, desintegrados e desinformados.

A solução apresentada pelo ordenamento jurídico, conforme visto, concentra-se no exercício do poder de polícia administrativa para fiscalizar as normas de proteção ao trabalhador. Ou seja, a proposta fundamenta-se na coerção para incentivar condutas. $\mathrm{O}$ problema é que tal solução deixa de ser eficiente, na medida em que, na falta de graves e iminentes riscos à vida do trabalhador, apenas cabem medidas de coerção indiretas, quais

\footnotetext{
${ }^{511}$ SHAPIRO, Sidney A. op. cit., p. 600.
} 
sejam, as autuações. A imposição de multas não promove a regularização e aumento do bem-estar (utilidade) e o empregador inclui, portanto, a medida administrativa (ação fiscal e auto de infração) como parte do risco da atividade econômica e não como mecanismo eficiente de melhoria das condições de trabalho. A legislação apenas prevê medidas coercitivas diretas no caso de grave e iminente risco. Nessa hipótese, o Estado impõe embargo ou interdição, paralisando a atividade econômica. O empregador, nessa circunstância, é impelido à promoção das medidas de proteção à vida do trabalhador.

Observa-se que a hipótese do grave e iminente risco se reduz à exposição a acidentes que gerem risco de morte imediata. Contudo, demais hipóteses de risco à saúde não ensejam medidas coercitivas diretas; há falta de incentivo para os casos em que os danos são provocados a médio ou a longo prazo, como na hipótese de perda de audição (doença profissional). E os custos com o pagamento de benefícios previdenciários ou aposentadorias por invalidez permanente são suportados pela coletividade, resultando em um quadro de ineficiência, conforme as análises trazidas nesse breve estudo.

Em face disso, embora as normas regulamentadoras de saúde e segurança sejam um importante instrumento de proteção à saúde do trabalhador, a sua efetividade depende de grande aporte de investimento público na área de fiscalização do trabalho e no aparato judicial, os quais acabam por compensar a deficiência de informação do trabalhador e a baixa representatividade dos sindicatos. Diante das limitações orçamentárias, as medidas compensatórias e o aparato estatal (administrativo e judicial) tornam-se pouco eficientes, em face dos custos apontados.

\subsection{Modelo de responsabilidade civil extracontratual}

A fim de estimular as condutas, além das medidas compensatórias e do aparato estatal, o legislador adota um modelo de responsabilidade civil extracontratual. O critério para um modelo eficiente de responsabilidade civil extracontratual, isto é, no contexto de uma análise econômica do Direito, deve ser o custo. A responsabilidade contratual deriva das próprias cláusulas elaboradas pelos agentes econômicos ou partes contratantes. A questão reside no modelo de atribuição de responsabilidade decorrente de ato ilícito (responsabilidade extracontratual). De forma pragmática, há três regras possíveis as quais se passa a analisar. 


\subsubsection{Regra da responsabilidade zero}

Dados dois indivíduos, qualquer um dos dois pode assumir a condição de agente ou de vítima, dependendo a quem for atribuída a responsabilidade. Se não houver qualquer atribuição de responsabilidade pela falta de cuidado, o grau de diligência dos agentes econômicos tende a ser nulo.

Dessa maneira, se a responsabilidade zero for atribuída ao empregador (agente): não haverá nenhum incentivo à implementação de medidas de prevenção a acidentes de trabalho, pois o custo será atribuído integralmente ao trabalhador (vítima).

Por outro lado, se a responsabilidade zero for atribuída ao trabalhador (agente): não haverá nenhum cuidado do trabalhador em evitar o risco, já que saberá que o mesmo será integralmente arcado pelo empregador (vítima).

Na primeira situação, o empregador provoca o dano em razão da falta de adoção do cuidado devido para evitar o acidente, já que o custo do dano para ele é zero. Portanto, o empregador assume a condição de agente e o trabalhador é a vítima. Na segunda hipótese, o trabalhador não age com o cuidado devido, pois sabe que a compensação do dano será integralmente atribuída ao empregador.

\subsubsection{Responsabilidade estrita (objetiva)}

Há apenas uma solução ótima que minimiza os custos sociais da sociedade. Nesse caso, dados os dois agentes econômicos, atribui-se o custo do dano integralmente ao agente que explora a atividade de risco e que detém presumidamente a maior informação. Diante da assimetria de informação, o agente que se encontra comparativamente em vantagem assume o risco do dano causado e, portanto, ele terá de arcar com o custo total de cuidado para evitar o dano. Haveria de se indagar: como evitar o risco moral (moral hazard) a que estará sujeito o empregador?

Na hipótese de responsabilidade objetiva e de acordo com a teoria do risco moral, "os trabalhadores tendem a ser menos vigilantes e, portanto, sofrem mais (e mais sérios) 
danos à saúde, porque benefícios cada vez maiores diminuem os riscos econômicos pessoais associados a tais danos". 512

Embora o legislador brasileiro não tenha adotado o modelo de responsabilidade estrita (conforme foi enunciado no capítulo anterior), a CLT prevê que a ausência de cuidado do empregado, uma vez atendidas as normas de proteção e segurança (ou seja, o empregador arcou com o custo total de cuidado/prevenção contra acidentes), autoriza o empregador a dispensar o trabalhador por justa causa. Do contrário, em um modelo de responsabilidade objetiva, haveria o risco de que o empregado propositalmente aproveitasse qualquer oportunidade, por exemplo, para não usar o EPI e, sendo dever do empregador garantir o efetivo uso, em caso da ocorrência do dano, o trabalhador teria direito a uma indenização. A dispensa por justa causa é uma medida de incentivo para o trabalhador agir com o cuidado devido.

Uma vez que se consiga criar mecanismos de minimização do risco moral, a responsabilidade objetiva apresenta como vantagem a diminuição do custo de transação arcado pela vítima e maior incentivo à adoção do cuidado devido pelo agente. É por essa razão que, ainda que o texto constitucional preveja que a indenização por dano causado por acidente dependa da comprovação de dolo ou culpa do empregador, o Ministério da Previdência Social elaborou um quadro que aponta a existência de relação entre a lesão ou agravo e a atividade desenvolvida pelo trabalhador, a partir de estudos científicos fundados em dados estatísticos e epidemiológicos. Trata-se do denominado "Nexo Técnico Epidemiológico Previdenciário" (NTEP). De acordo com informações do próprio Ministério da Previdência Social,

o NTEP foi implementado nos sistemas informatizados do INSS, para concessão de benefícios, em abril/2007 e de imediato provocou uma mudança radical no perfil da concessão de auxílios-doença de natureza acidentária: houve um incremento da ordem de 148\%. Este valor permite considerar a hipótese que havia um mascaramento na notificação de acidentes e doenças do trabalho. O Departamento de Saúde e Segurança Ocupacional da Secretaria de Políticas de Previdência Social apresenta a apuração mensal da quantidade de auxílios-doença concedidos, de natureza previdenciária e acidentária, segundo os códigos da Classificação Internacional de Doenças - CID-10 e semestralmente apresentará a evolução do quadro. Os dados informados abrangem,

\footnotetext{
${ }^{512}$ SHAPIRO, Sidney A. op. cit., p. 604.
} 
inicialmente, as análises relativas aos anos de 2006 e 2007 e as informações parciais mensais relativas a $2008 .^{513}$

A partir do NTEP, identificaram-se doenças causalmente relacionadas a determinadas atividades econômicas, isto é, houve cruzamento dos dados do CNAE (Classificação Nacional de Atividade Econômica) com os do CID-10 (Classificação Internacional de Doenças) e, estatisticamente, constatou-se riscos inerentes a atividades econômicas. Isso significa que ao trabalhador não é transferido o ônus de comprovar o nexo causal, pois este é objetivamente calculado pelo NTEP. Trata-se de um avanço no sistema de previdência rumo à adoção da teoria do risco.

Como analisa Rui Stocco, a responsabilidade do empregador, em caso de acidente de trabalho, deveria ser objetiva, por força da teoria do risco ${ }^{514}$. Mas não foi essa a inteligência do legislador constituinte, escolha essa que, com base em uma análise econômica, não foi eficiente em uma sociedade complexa e de risco.

\subsubsection{Responsabilidade subjetiva (culpa ou dolo)}

De acordo com o artigo $7^{\circ}$, inciso XXVIII, da Constituição Federal, em caso de acidente de trabalho e comprovado o dolo ou a culpa, o empregador estará obrigado a pagar indenização. Isso significa que o modelo baseia-se em um padrão devido de cuidado, o qual, conforme se depreende, está expresso no conteúdo das normas de saúde e de medicina do trabalho.

Questionou-se se o legislador manteve a opção pelo modelo da responsabilidade subjetiva, após o advento do Código Civil de 2002 (CC/2002), que, em seu artigo 927, dispõe: "Haverá obrigação de reparar o dano, independentemente de culpa, nos casos

\footnotetext{
${ }^{513}$ BRASIL. MINISTÉRIO DA PREVIDÊNCIA SOCIAL. Informações Estatísticas Relativas à Segurança e Saúde Ocupacional. Disponível em: <http://www.previdencia.gov.br/conteudoDinamico.php?id=500>. Acesso em: 02 jan. 2009.

${ }^{514}$ STOCCO, Rui. Tratado de responsabilidade civil: responsabilidade civil e sua interpretação doutrinária e jurisprudencial. 5. ed. São Paulo: Ed. Revista dos Tribunais, 2001. p. 476.
} 
especificados em lei, ou quando a atividade normalmente desenvolvida pelo autor do dano implicar, por sua natureza, risco para os direitos de outrem". 515

O dispositivo acima permite indagar se haveria responsabilidade objetiva quando a atividade normalmente desenvolvida implica risco para os direitos de outrem. Gustavo Filipe Barbosa Garcia, ao se debruçar sobre o tema, identificou duas correntes: a primeira corrente entende pela aplicação da norma do Código Civil em caso de acidente de trabalho; a outra é contrária, mantendo a necessidade de comprovação de dolo ou culpa para responsabilização do empregador. Segundo o autor, os que defendem a responsabilidade objetiva nos acidentes de trabalho sustentam que seria paradoxal que um terceiro, uma vez identificada a atividade como de risco, pudesse receber indenização sem necessidade de comprovar culpa ou dolo, enquanto o trabalhador tivesse de suportar esse ônus por força do texto constitucional. Contrariamente a essa orientação, defende-se a responsabilidade subjetiva (aquiliana) sob o argumento de que a responsabilidade objetiva deve constar expressamente do texto legal e não pode decorrer de uma interpretação extensiva. Ademais, o texto constitucional é claro e traz uma norma específica em casos de acidente de trabalho, a qual não pode ser derrogada por disposição genérica infraconstitucional. Nem caberia cogitar da aplicação da norma mais favorável, pois a mesma se restringe à interpretação das cláusulas e das normas trabalhistas que incidem sobre o contrato de trabalho, e a responsabilidade do empregador estudada é de natureza civil e extracontratual. ${ }^{516}$

A partir dessas considerações, observa-se que o modelo adotado pelo Código Civil é de responsabilidade objetiva do empregador diante de danos causados a terceiros, com vistas a diminuir o custo de transação, dado que a atividade econômica explorada é reconhecidamente pelo ordenamento jurídico como de risco. É a hipótese do dano nuclear, previsto no art. 21, inciso XXIII, $d$, da Constituição Federal de 1988.

Examina-se o impacto do artigo 927 do CC/2002 frente ao dispositivo constitucional, que determina a responsabilidade subjetiva do empregador em acidentes de trabalho. A interpretação do artigo do Código Civil é de que, para fins de responsabilidade

\footnotetext{
${ }^{515}$ CAHAli, Yussef. (Org.). Constituição Federal, Código Civil, Código de Processo Civil, Código Comercial. 9. ed. rev. ampl. e atual. São Paulo: Ed. Revista dos Tribunais, 2007. p. 337.

${ }^{516}$ GARCIA, Gustavo Filipe Barbosa. Meio ambiente do trabalho: direito, segurança e medicina do trabalho. São Paulo: Ed. Método, 2006. p. 46-47.
} 
por acidente de trabalho, os empregados não se enquadram na categoria de "terceiros" prevalecendo o texto constitucional (responsabilidade subjetiva). Mas, e se o empregado sofre um acidente de trabalho ou adquire uma doença profissional em decorrência de dano nuclear? Nessa hipótese, é o próprio texto constitucional que estabelece a responsabilidade objetiva do empregador, que pode ser a Administração Pública ou um empregador que exerça a atividade nuclear em regime de concessão ou permissão.

A inconsistência e a falta de um modelo eficientemente elaborado permitem falhas de comunicação e de informação. O resultado é o aumento do custo de transação e, mais ainda, pouco incentivo para estimular condutas conforme o devido padrão de cuidado (minimização de danos e, portanto, mais custos).

Gustavo Filipe Barbosa Garcia propõe a modificação do dispositivo constitucional sobre responsabilidade civil do empregador por acidente do trabalho, "de modo a permitir a incidência da responsabilidade objetiva para os casos em que a atividade normalmente desenvolvida pelo autor do dano implicar, por sua natureza, risco para os direitos de outrem" ${ }^{\text {518 }}$, a exemplo do que já fez o constituinte ao tratar da responsabilidade por dano nuclear.

De acordo com a legislação vigente, a atribuição da responsabilidade objetiva do empregador não implicaria, como visto, ausência de custo com o cuidado por parte da vítima (empregado). O empregado assume, na relação de trabalho, a responsabilidade de agir, conforme o devido padrão de cuidado definido pela legislação. Isto é, uma vez que o empregador adotou as medidas de proteção de saúde e de medicina do trabalho integralmente, o comportamento do empregado deve se orientar conforme as medidas implementadas, sob pena de arcar com o custo da perda do emprego. Nesse caso, a responsabilidade do empregado é subjetiva, pois, uma vez comprovado o dolo ou a culpa, autoriza-se o empregador a proceder com a dispensa por justa causa do trabalhador. Porém a dispensa nesses moldes deve ocorrer antes do advento do dano à saúde ou à vida do

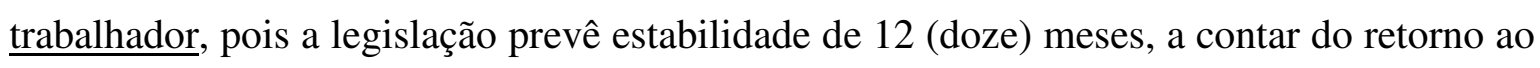
trabalho, para o empregado acidentado no trabalho ou acometido por doença

\footnotetext{
${ }^{517}$ Vide TRT $2^{\text {a }}$ Reg - RO 01187200204802008 - Ac. $7^{\text {a }}$ T. 20050595177 - Rel . Juíza Catia Lungov - DJSP 09.09.2005, p. 16 .

${ }^{518}$ GARCIA, Gustavo Filipe Barbosa. Meio ambiente do trabalho: direito, segurança e medicina do trabalho, cit., p. 51.
} 
profissional $^{519}$. Portanto, durante o período de afastamento e antes de completados doze meses de retorno ao trabalho, o empregado não poderá ser dispensado.

Quais as consequências de um modelo dessa natureza, sob uma análise econômica? Assume-se a hipótese de que o modelo é de responsabilidade objetiva para as atividades de risco, como a atividade nuclear. O empregador adota todas as medidas de segurança previstas, ou seja, o agente suporta integralmente com o custo com cuidado. Porém, se, plenamente informado sobre o modelo de responsabilidade objetiva, o empregado adotar uma postura negligente, porque sabe que o custo do dano será suportado pelo empregador? Sabe-se que o trabalhador tem o custo da perda do emprego, antes de ocorrido o dano. Mas e se o dano ocorrer por culpa do trabalhador, antes da dispensa por justa causa pelo empregador?

Aqui se enfrenta o problema de, em um modelo de responsabilidade civil objetiva, contornar as falhas do modelo jurídico de racionalidade, que visa aproximar o homem real a um homem ideal. A partir da ideia de razão humana maximizadora do bem "vida", pode parecer absurdo que um trabalhador deixe de usar um EPI e propositalmente exponha a sua vida a uma situação de risco, com vistas à percepção de uma indenização. Mas o Direito não pode afastar as consequências do risco moral (moral hazard) e da seleção adversa. Na situação mencionada, há duas possibilidades de análise: a) o empregador é responsável objetivamente, em face do risco da atividade; ou b) o empregador é responsável subjetivamente, ou seja, será responsável se restar comprovada a culpa in vigilando ou in eligendo.

No primeiro item, a solução não seria eficiente, na medida em que, independentemente da adoção de medidas de proteção ou não, o empregador seria responsável, mesmo quando o trabalhador tivesse dado origem ao dano por culpa ou dolo. A responsabilidade objetiva, nessa situação, sem admitir a hipótese do moral hazard, não incentivaria condutas de cuidado. Imagine-se a situação em que o empregador acaba de adquirir um novo EPI, que elimina o risco da insalubridade. $\mathrm{O}$ empregador promove treinamento a seus trabalhadores, todos qualificados e com formação adequada para o exercício da atividade laboral. Um dos trabalhadores, contudo, por interesse particular,

\footnotetext{
${ }^{519}$ Lei 8.213/91: “Art. 118 - O segurado que sofreu acidente do trabalho tem garantida, pelo prazo mínimo de doze meses, a manutenção do seu contrato de trabalho na empresa, após a cessação do auxílio-doença acidentário, independentemente de percepção de auxílio-acidente."
} 
pondera os bens envolvidos - vida versus vantagem pecuniária - e opta pela indenização, sem considerar a ineficiência de sua escolha em termos de custo total. Dolosamente, esse trabalhador retira abruptamente o EPI durante a jornada de trabalho e, antes que seja possível evitar o dano ou tomar qualquer outra medida, sofre acidente com redução permanente de capacidade laborativa. Essa hipótese narrada soa como uma situação limite, mas que não pode ser descartada no processo de modelagem, com base no modelo de comportamento dos agentes econômicos. A responsabilidade objetiva do empregador, nesse caso, seria ineficiente. A solução mais adequada seria atribuir ao empregador a responsabilidade subjetiva, transferindo ao trabalhador o custo da comprovação da culpa ou do dolo. Ainda com base no exemplo enunciado, caberia ao trabalhador comprovar:

1) culpa in vigilando: o trabalhador, desconhecendo o grau do risco a que está exposto (informação assimétrica), não foi devidamente orientado, treinado ou fiscalizado durante a adoção das medidas de segurança (ex. uso do EPI);

2) culpa in eligendo: o trabalhador, pouco qualificado ou com má formação técnica e educacional, não consegue absorver a informação sobre as medidas de segurança (ex. contratação de mão-de-obra desqualificada porque o custo salarial é mais baixo).

Essas são meras considerações acerca de um modelo de responsabilidade objetiva, em face da interpretação do artigo $7^{\circ}$, inciso XXVIII, segunda parte, combinado com o artigo 21, inciso XXIII, $d$, ambos da Constituição Federal de 1988. Mas sabe-se que o legislador manifestou sua preferência pela responsabilidade subjetiva. E o comportamento do empregador pauta-se na comparação entre o custo do agente operar abaixo do padrão devido de cuidado e o custo do dano causado; se o custo do dano for menor, não haverá incentivo.

No modelo de responsabilidade subjetiva, como parte do custo do dano, agrega-se o custo de transação a ser suportado pela vítima (ex. comprovação do nexo causal, tempo, desgaste psicológico, custos judiciais), que pode desestimular a busca pela indenização e aumentar a falta de incentivo para a adoção do padrão de cuidado pelo agente causador do dano. A consequência é o aumento do custo social, com altos gastos suportados pela Previdência Social e a formação de um considerável contingente de indivíduos parcial ou totalmente incapacitados para o trabalho.

O modelo de responsabilidade civil, como exemplo aqui tratado, possibilita a condenação, pela via judicial, de reparar os danos individuais sofridos pelo trabalhador. 
Contudo, conforme foi analisado, o universo laboral envolve não apenas o indivíduo, mas toda uma coletividade. Enquanto as medidas de proteção de saúde e medicina do trabalho não forem eficientemente incentivadas, o risco da atividade permanece, isto é, a vida e a saúde não estão protegidas, comprometendo a razão de ser da própria sociedade e do Estado.

\subsection{A coerência valorativa do sistema juslaboral laboral e a adoção da jornada de $12 \times 36$}

A Consolidação das Leis do Trabalho, em seu artigo 193, dispõe:

Art. 193 - São consideradas atividades ou operações perigosas, na forma da regulamentação aprovada pelo Ministério do Trabalho, aquelas que, por sua natureza ou métodos de trabalho, impliquem o contato permanente com inflamáveis ou explosivos em condições de risco acentuado.

$\S 1^{\circ}$ - O trabalho em condições de periculosidade assegura ao empregado um adicional de $30 \%$ (trinta por cento) sobre o salário sem os acréscimos resultantes de gratificações, prêmios ou participações nos lucros da empresa.

$\S 2^{\circ}$ - O empregado poderá optar pelo adicional de insalubridade que porventura lhe seja devido.

O artigo 194 prevê a supressão do pagamento do adicional de insalubridade ou de periculosidade, em caso de eliminação de risco:

Art. 194 - O direito do empregado ao adicional de insalubridade ou de periculosidade cessará com a eliminação do risco à sua saúde ou integridade física, nos termos desta Seção e das normas expedidas pelo Ministério do Trabalho.

Observa-se que a legislação admite a exposição do trabalhador a um meio ambiente de trabalho que comprometa a sua saúde e o compensa com o pagamento de um adicional. O texto do artigo 194 deixa claro que o pagamento do adicional é devido, enquanto não cessada a eliminação do risco à saúde ou integridade física do trabalhador. Destarte, o dispositivo do diploma consolidado permite que o empregador avalie os custos entre pagar o adicional ou dotar o meio ambiente de condições favoráveis à eliminação do risco. Chega-se à seguinte conclusão: ainda que seja possível garantir a saúde do trabalhador - 
direito fundamental -, se for menos oneroso o pagamento do adicional, expõe-se o trabalhador a condições de dano à sua saúde e integridade física.

É certo que o legislador, em caso de constatada insalubridade, determinou um mecanismo de controle de efetividade, ao atribuir à fiscalização do trabalho a função de notificar o empregador para que adote medidas e equipamentos de proteção ao trabalhador:

Art. 191 - A eliminação ou a neutralização da insalubridade ocorrerá:

I - com a adoção de medidas que conservem o ambiente de trabalho dentro dos limites de tolerância;

II - com a utilização de equipamentos de proteção individual ao trabalhador, que diminuam a intensidade do agente agressivo a limites de tolerância.

Parágrafo único - Caberá às Delegacias Regionais do Trabalho, comprovada a insalubridade, notificar as empresas, estipulando prazos para sua eliminação ou neutralização, na forma deste artigo.

O impasse criado é que o legislador, em princípio, possibilitou uma certa "escolha" do empregador, o que não se sustenta no interior do sistema jurídico de proteção aos direitos humanos.

A mercantilização da saúde do trabalhador - expressa manifestação do código econômico - é mais pungente com a impossibilidade de acumulação de adicionais de periculosidade e insalubridade, decorrente do $\S 2^{\circ}$ do artigo 193 da CLT. O trabalhador que é exposto, por exemplo, a agentes químicos (insalubridade) e a agentes ionizantes (periculosidade) somente pode receber $\underline{\mathrm{um}}$ dos adicionais previstos na lei. Focando na estrutura da norma, subjacente repousa a óptica econômica de redução de custos: se o meio ambiente desfavorável à saúde do trabalhador é decorrente da atividade econômica desenvolvida, que seja pago um adicional, porém tão somente um. A mercantilização da saúde do trabalhador (fator de produção) não escapa da dinâmica da redução de custos.

Uma das teses apresentadas e aprovadas pela Anamatra (Associação Nacional dos Magistrados Trabalhistas), no Congresso já mencionado, ressalta outro aspecto atentatório à dignidade humana, no que tange à disciplina do pagamento de adicionais por exposição a agentes nocivos. Trata-se do artigo $193, \S 2^{\circ}$, da CLT, criticado pelo Magistrado Nelson Hamilton Leiria: 


\section{4 - Parágrafo $2^{\circ}$ do artigo 193 da CLT. Revogação por ofensa à Constituição Federal}

\section{Autor: Nelson Hamilton Leiria}

O $\S 2^{\circ}$ do art. 193 da CLT encontra-se revogado por não ter sido recepcionado pela Constituição Federal, já que seu comando ofende os princípios da dignidade da pessoa humana e valor social do trabalho, além de ser discriminatório. Os adicionais de remuneração visam a compensar as condições mais desgastantes de trabalho. Assim, a opção entre o recebimento do adicional de insalubridade ou periculosidade beneficia o empregador, que mantém dupla ofensa ao meio ambiente de trabalho saudável, e prejudica o empregado que deixa de receber o adicional por um dos agentes. Portanto, coexistentes as condições de insalubridade e periculosidade, são devidos de forma cumulativa ambos os adicionais.

Cabe a crítica ao dispositivo da CLT que prevê a impossibilidade de acumulação de adicionais de insalubridade e periculosidade. Não obstante a "irritação" provocada por alguns dispositivos do próprio sistema jurídico, torna-se imperioso, portanto, resgatar os institutos que mantêm a coerência interna. No caso em análise, diante de um cenário de total ausência de efetividade de normas de proteção à saúde do trabalhador, os institutos de embargo de obra ou interdição de estabelecimento, setor de serviço, máquina ou equipamento - meios diretos de coerção no exercício do Poder de Polícia Administrativa ou por requisição do Poder Judiciário - devem ser acionados.

O Direito do Trabalho, enquanto sistema, corre assim o risco da invasão do sistema econômico em sua base de referência. À medida que o sistema jurídico não consegue manter suas fronteiras de sentido, o referencial econômico paulatinamente avança. Exemplo disso é a prática da jornada de $12 \mathrm{X} 36$. Na autorização da jornada de $12 \mathrm{X} 36$, ao ponderar o direito de limitação de jornada e o direito à negociação coletiva, apresentam-se duas decisões contrárias. A $2^{\text {a }}$ Turma do TST, em acórdão publicado em 30 de maio de 2008, posiciona-se pela ilicitude do instituto:

NÚMERO ÚNICO PROC: RR - 3783/2003-035-12-00

PUBLICAÇÃO: DJ - 30/05/2008

ACORDO DE COMPENSAÇÃO. REGIME 12x36. PREVISÃO EM NORMA COLETIVA.

INVALIDADE

\section{I - CONHECIMENTO}

O Tribunal Regional do Trabalho, analisando o tema em comento, assim dispôs em sua fundamentação, in verbis : 
O Juiz de primeiro grau indeferiu as horas extras, assim consideradas as excedentes da $8^{a}$ diária, ao fundamento de que o regime de $\mathbf{1 2 \times 3 6}$ horas é correto, tendo em vista a expressa previsão nas convenções coletivas de trabalho da categoria profissional do autor. Fundamentou ainda que a adoção desse regime é benéfico do empregado. É certo que a Constituição Federal/88, em seu art. $7^{\circ}$, inc. XIII, faculta a compensação de horários; porém, a CLT, em seu art. $59, \S 2^{\circ}$, ao regulamentar a compensação de horário, determina que não seja ultrapassado o limite máximo de 10 horas diárias.

Portanto, o regime de $\mathbf{1 2 \times 3 6}$ horas, independentemente de acordo tácito ou escrito, individual ou coletivo, é ilegal, por extrapolar o limite máximo de 10 horas diárias. Diante da impossibilidade legal de jornada de 12 horas, o reclamante faz jus ao recebimento de duas horas diárias, mais o adicional previsto nas convenções coletivas juntadas com a inicial, já que a compensação da $9^{\mathrm{a}}$ e da $10^{\mathrm{a}}$ horas é permitida legalmente.

No XIV Congresso Nacional dos Magistrados da Justiça do Trabalho, realizado em 2008 em Manaus, 47 teses foram aprovados, tendo por tema central "O homem, o trabalho e o meio: uma visão jurídica e sociológica". Uma delas reforça a ilicitude da jornada 12X36:

\section{8 - Absoluta invalidade da jornada $12 \times 36$}

\section{Autora: Candy Florencio Thomé}

O regime de 12 horas de trabalho por 36 de descanso deve ser sempre considerado inválido em virtude de proibição legal e do risco de aumento do número de acidentes que gera.

Entretanto, em outro julgado, publicado na mesma data do acórdão anteriormente reproduzido, a $7^{\mathrm{a}}$ Turma do TST entendeu pela licitude da modalidade de jornada:

NÚMERO ÚNICO PROC: RR - 48738/2002-900-02-00

PUBLICAÇÃO: DJ - 30/05/2008

RECURSO DE REVISTA. HORAS EXTRAS. COMPENSAÇÃO DE JORNADA. REGIME 12 X 36. NORMA COLETIVA. VALIDADE.

1. Esta Justiça do Trabalho tem primado por incentivar e garantir o cumprimento das negociações coletivas, desde que devidamente formalizadas. Sendo, pois, um instrumento do qual as partes podem se valer para regulamentar as relações de trabalho, a norma inserida em convenção coletiva de trabalho há de prevalecer, com respaldo na Constituição Federal, já que a transação realizada em ação coletiva resulta de ampla negociação, em que perdas e ganhos recíprocos têm presunção de comutatividade.

(...)

V O T O 


\section{MÉRITO}

\section{1 - HORAS EXTRAS. COMPENSAÇÃO DE JORNADA. REGIME 12 X 36. PAGAMENTO}

\section{DAS HORAS EXCEDENTES À $10^{\mathrm{a}}$ DIÁRIA.}

Esta Justiça do Trabalho tem primado por incentivar e garantir o cumprimento das negociações coletivas, desde que devidamente formalizadas.

Sendo, pois, um instrumento do qual as partes podem se valer para regulamentar as relações de trabalho, a norma inserida em convenção coletiva de trabalho há de prevalecer, com respaldo na Constituição Federal, já que a transação realizada em ação coletiva resulta de ampla negociação, em que perdas e ganhos recíprocos têm presunção de comutatividade. Portanto, o resultado atingido pela autocomposição das partes não pode ser avaliado por um dispositivo ou outro considerado isoladamente; deve-se levar em conta o conjunto do instrumento coletivo, para não debilitar o equilíbrio dos interesses que o originaram e, conseqüentemente, valorizar o processo de negociação e a composição autônoma preconizados pela Constituição Federal.

Assim, as cláusulas pactuadas livremente pelas partes devem se interpretadas de forma global, uma vez que a categoria profissional pode ter negociado determinadas vantagens por um certo período, levando em consideração circunstâncias momentâneas, objetivando interesses maiores. Dessa forma, o estabelecimento de condições mais restritivas em um dispositivo pode estar sendo compensado em outros, com a concessão de vantagens e garantias coletivas em patamares mais elevados que aqueles fixados na legislação.

Restou incontroverso nos autos que o Acordo Coletivo de Trabalho firmado entre o sindicato da categoria profissional do reclamante e a reclamada, pactuou a compensação de jornada instituída em norma coletiva de trabalho, para cumprimento de revezamento em regime de 12 horas de trabalho por 36 horas de descanso.

Ante o exposto, DOU PROVIMENTO ao recurso de revista para restabelecer a $\mathrm{r}$. sentença. ISTO POSTO ACORDAM os Ministros da Sétima Turma do Tribunal Superior do Trabalho, por unanimidade, conhecer do recurso de revista por divergência jurisprudencial e, no mérito, dar-lhe provimento para restabelecer a r. sentença.

Brasília, 28 de maio de 2008.

\section{CAPUTO BASTOS}

Ministro Relator

Diante das características de determinadas atividades - como exemplo citam-se os enfermeiros -, há quem sustente a ausência de ilegalidade na fixação da jornada acima enunciada, desde que conste expressamente em instrumento normativo de natureza coletiva. Dessa ordem de ideias, resulta a indagação: se o motivo que justificou a admissão da jornada pautou-se nas peculiaridades das atividades, as quais não admitiriam solução de 
continuidade, como permitir, por exemplo, que o porteiro se ausente por, no mínimo, uma hora do seu local de trabalho? Por essa razão, uma vez considerada lícita a jornada de 12X36, afastando-se assim os dispositivos sobre extrapolação de jornada constantes do diploma consolidado, entidades sindicais e empregadores interpretaram que, diante da especificidade da jornada, não caberia nem mesmo a concessão de intervalo para repouso e alimentação. Em decisões bem recentes do TST, o entendimento predominante é de que, não obstante a especificidade da jornada, a concessão de intervalo para repouso e alimentação é devida.

RR - 3128/2002-900-03-00

PUBLICAÇÃO: DJ - 30/05/2008

ACÓRDÃO

$7^{\mathrm{a}}$ Turma

RECURSO DE REVISTA. HORAS EXTRAS. ACORDO DE COMPENSAÇÃO DE JORNADA $12 X 36$ HORAS. INTERVALO INTRAJORNADA.

A decisão do Tribunal merece ser mantida, quanto às horas extras deferidas pela não concessão do intervalo intrajornada mínimo de 1 hora, nos termos do entendimento jurisprudencial da SBDI-1, desta Corte, no sentido de que o empregado que labora em regime de compensação de jornada, em escala de $12 \times 36$ horas, ainda que encetada mediante acordo coletivo, faz jus ao intervalo intrajornada, por tratar-se de direito assegurado em norma de ordem pública (artigo 71, $4^{\circ}$, da CLT) e, portanto, indisponível pela vontade das partes, uma vez que tutelares da higiene, saúde e segurança do trabalho (TST-E-ED-RR- 1343/1999-00217-00, SBDI-1, Relator Ministro João Oreste Dalazen, DJ de 06/10/2006). Recurso de revista conhecido e não provido. [grifo nosso] ${ }^{520}$

\footnotetext{
${ }^{520}$ Nesse sentido:

RR - 11746/2002-900-03-00 Publicado DJ - 16/05/2008- ACÓRDÃO 1ª TURMA

RECURSO DE REVISTA. HORAS EXTRAS. INTERVALO INTRAJORNADA. SUPRESSÃO.

PREVISÃO EM ACORDO COLETIVO.

Viola o art. 71, § $4^{\circ}$, da CLT decisão que vai de encontro à jurisprudência pacificada no âmbito desta Corte Uniformizadora, no sentido da impossibilidade de o instrumento coletivo prever a inexistência de intervalo para descanso e alimentação do trabalhador. Eis a Orientação Jurisprudencial no 342 da SBDI-1: É inválida cláusula de acordo ou convenção coletiva de trabalho contemplando a supressão ou redução do intervalo intrajornada porque este constitui medida de higiene, saúde e segurança do trabalho, garantido por norma de ordem pública (art. 71 da CLT e art. $7^{\circ}$, XXII, da Constituição Federal de 1988), infenso à negociação coletiva.

RR - 1817/2002-104-03-00 Publicado DJ - 23/05/2008 Acórdão 5 ${ }^{\text {a TURMA }}$

RECURSO DE REVISTA. INTERVALO INTRAJORNADA. REDUÇÃO OU SUPRESSÃO MEDIANTE NEGOCIAÇÃO COLETIVA. INVALIDADE. PREVALÊNCIA DAS NORMAS DE HIGIENE, SAÚDE E SEGURANÇA DO TRABALHO. Para concluir pela invalidade de cláusula de acordo ou convenção coletiva de trabalho, em que é prevista a supressão ou redução do intervalo intrajornada, este Tribunal superior considerou que, em respeito ao princípio da proteção e da dignidade humana, prevalecem as medidas de higiene, saúde e segurança do trabalho, por se tratar de normas de ordem pública. Prevalência do disposto no art. $7^{\circ}$, XXII, da Constituição Federal sobre o inciso XXVI do mesmo dispositivo. Decisão do Regional em conformidade com a diretriz traçada na Orientação Jurisprudencial n 342 da SBDI-1 desta Corte. Recurso de revista de que não se conhece.
} 
Nessa hipótese, diante de duas normas admitidas no ordenamento jurídico - artigo da CLT e cláusula de acordo coletivo - a aplicação da regra mais favorável ao trabalhador prestigiou o bem comum a todos os homens: a saúde.

A primeira decisão apoiou-se em uma interpretação sistemática, contemplando os dispositivos da CLT, que autorizam a compensação de jornada até o máximo de 10 (dez) horas (artigo 59, caput). A negociação coletiva que resulte em norma coletiva em sentido contrário não é válida, por afronta à legislação mais favorável ao trabalhador. No segundo acórdão, prestigiou-se a negociação coletiva, como direito fundamental expresso no artigo $7^{\circ}$, inciso XXVI, da Constituição Brasileira. Como resultado, declarou a licitude da jornada de $12 \mathrm{X} 36$, desconsiderando um elemento fundamental no sistema jurídico que justifica a limitação da jornada: a saúde do trabalhador.

A importância da limitação de jornada é indiscutível. A primeira Convenção da Organização Internacional do Trabalho, em 1919, versava exatamente sobre a jornada de trabalho, dispondo em seu artigo $2^{\circ}$ :

A jornada de pessoas empregadas em quaisquer atividades industriais públicas ou privadas ou em qualquer segmento dessa natureza, com exceção das atividades em que apenas os membros de uma mesma família sejam empregados, não deve exceder oito horas diárias e quarenta e oito semanais $(\ldots)^{521}$

Em 1905, Evaristo de Moraes destacava os efeitos biológicos provocados pela fadiga, quer fosse ela intelectual ou muscular. Para o autor, a fadiga produz perturbações

\footnotetext{
RR - 14401/2001-651-09-00 Publicado DJ - 23/05/2008 - Acórdão 2a Turma

RECURSO DE REVISTA. INTERVALO INTRAJORNADA. Conquanto tenha sido intenção do legislador constituinte garantir a prevalência das convenções e acordos coletivos, não é possível reconhecer-se como válida a norma coletiva que se contrapõem à legislação atinente à segurança e saúde no trabalho. Com efeito, as normas coletivas não têm o condão de validar a supressão ou a diminuição de direitos trabalhistas indisponíveis. Significa dizer que a interpretação sistemática do ordenamento jurídico obriga ao aplicador da lei considerar, conjuntamente àquele artigo $7^{\circ}$, inciso XXVI da Constituição, o conteúdo do artigo 71 , $\S 3^{\circ}$ da CLT, no sentido de que o limite mínimo de uma hora para repouso ou refeição poderá ser reduzido, apenas, por ato do Ministro do Trabalho, após consulta à Secretaria de Segurança e Medicina do Trabalho (SSMT). Decisão regional em consonância com a Orientação Jurisprudencial no 342 da C. SBDI-1 do TST. Recurso de revista não conhecido.

AIRR - 1215/2004-301-01-40 Publicado em DJ - 16/05/2008 - Acórdão $8^{\text {a }}$ Turma

AGRAVO DE INSTRUMENTO EM RECURSO DE REVISTA. INTERVALO INTRAJORNADA. REDUÇÃO. PREVISÃO EM NORMA COLETIVA. INVALIDADE. Estando o acórdão Regional em consonância com a Orientação Jurisprudencial 342 da SBDI-1 do TST, o Recurso de Revista encontra óbice no art. 896, $\S 4^{\circ}$, da CLT e na Súmula 333 do TST. Agravo de Instrumento a que se nega provimento.

${ }^{521}$ THE INTERNATIONAL LABOUR ORGANIZATION. Convention 1 - Hours of Work (Industry) Convention, 1919. Disponível em: <http://www.ilo.org/ilolex/english/convdisp1.htm>. Acesso em: 14 jun. 2008.
} 
da atenção, da sensibilidade em geral e os movimentos são menos enérgicos. ${ }^{522} \mathrm{~A}$ limitação da jornada, em princípio, justifica-se biologicamente. Trata-se de uma questão de saúde físico-mental do trabalhador. O Dieese, em nota técnica, ressalta que "em função das jornadas extensas, intensas e imprevisíveis, os trabalhadores têm ficado cada vez mais doentes (estresse, depressão, hipertensão, distúrbios no sono e lesão por esforços repetitivos, por exemplo).,"523

Dessa forma, sustentar a jornada de 12 X36 pressupõe uma lógica que não passa por uma interpretação jurídico-teleológica, qual seja, o fim de proteger o ser humano que trabalha. Prevalece em alguns julgados, a exemplo do reproduzido acima, o direito ao reconhecimento das convenções e acordos coletivos de trabalho, porém sem ponderar que o próprio legislador infraconstitucional limitou qualquer alteração contratual, incluindo as normas coletivas, à seguinte regra:

Art. 468. Nos contratos individuais de trabalho só é lícita a alteração das respectivas condições por mútuo consentimento, e ainda assim desde que não resultem, direta ou indiretamente, prejuízos ao empregado, sob pena de nulidade da cláusula infringente desta garantia.

Desse dispositivo destaca-se a garantia do princípio protetor, que compreende a norma mais favorável. Sem adentrar na discussão sobre as relações coletivas de trabalho, vale apenas mencionar o que afirmava Jean Cruet, em obra publicada no início do século $\mathrm{XX}$ :

"a soberania econômica dos sindicatos, toda relativa de resto, não é
menos um fato, uma força. E visível que, na grande indústria, o operário
sofre tanto a autoridade do sindicato como a do Estado". ${ }^{24}$

Os debates trazidos nesse estudo - base de cálculo do adicional de insalubridade e a jornada de 12X36 - demonstram que o código lícito/ilícito amparado no conteúdo da CLT não é mais suficiente, dado o anacronismo do texto consolidado frente às mudanças no mundo do trabalho. Observa-se que a máquina juslaboral não foi bem elaborada tendo em vista a CF/88. E como fica então a proteção efetiva da saúde humana? E o que passa a ser

\footnotetext{
${ }^{522}$ MORAES, Evaristo. Apontamentos de direito operário. 4. ed. São Paulo: LTr, 1998. p. 84-85.

${ }^{523}$ DEPARTAMENTO INTERSINDICAL DE ESTATÍSTICAS E ESTUDOS ECONÔMICOS - DIEESE. Nota técnica: argumentos para a discussão da redução da jornada no Brasil sem redução do salário. abr. $2008 . \quad$ p. 4.4 Disponível $<$ http://www.dieese.org.br/notatecnica/notatec66argumentosReducaoJornada.pdf. Acesso em: 14 jun. 2008.

${ }^{524}$ CRUET, Jean. À vida do direito e à inutilidade das leis. Leme: Edijur, 2002. p. 115.
} 
saúde na $\mathrm{CF} / 88$, com aplicação nas relações de trabalho subordinado? Entende-se que por saúde deve-se compreender o bem- estar físico, mental e também social do trabalhador e da coletividade atingida ou influenciada pelo modelo adotado de relação de trabalho subordinado.

Há de compreender que a proteção à dignidade do trabalhador é destinada ao próprio sistema juslaboral, para assegurar a efetividade de sua função de contemplar a complexidade e reduzir os conflitos. Contudo, quando se admite a jornada de $12 \mathrm{X} 36$, o debate estendeu-se e encampou a eventual possibilidade de redução do intervalo de repouso e alimentação, com comprometimento da saúde e da própria segurança do trabalhador. A consequência dessa escolha reflete-se na ampliação do potencial de conflitos, na medida em que a coerência valorativa não é mantida. Se não se observar a presença da complexidade de interesses e de exercício de poder no processo dinâmico das relações de trabalho subordinado, tende-se para soluções consideradas pouco eficientes jurídica, social, política e economicamente.

A organização do trabalho constitui uma questão fundamental na discussão sobre proteção à saúde e segurança do trabalhador. Um dos elementos fundamentais da organização do trabalho é a jornada de trabalho. A flexibilização do sistema de jornada não garantiu a dignidade do trabalhador, na medida em que comprometeu a sua vida social e a própria segurança. O desgaste da incerteza da duração da jornada pode causar danos psíquicos e físicos irreparáveis. Dados sobre o número de mutilações provocadas por acidentes de trabalho revelam a fragilidade do sistema juslaboral. E, no mais das vezes, são pequenos ajustes (ou desajustes) promovidos na legislação e/ou jurisprudência que fomentam esse quadro alarmante.

Uma das maiores dificuldades para reversão desse cenário de violação à vida e à saúde dos trabalhadores está no discurso alimentado ao longo da história brasileira acerca da ideia de propriedade. A função social da propriedade ainda é um discurso a ser intercambiado nas relações sociais de poder, de sorte que a atuação do Ministério do Trabalho e Emprego é de extrema relevância nesse aspecto.

É certo que o motivo que leva o legislador a determinar por meio de normas os contornos de certos comportamentos esperados dos e pelos indivíduos são os bens jurídicos que merecem proteção, segundo os critérios adotados por determinada sociedade. E, em uma sociedade constituída sob a noção de propriedade, não se espanta que "a proibição do 
roubo [...] muitas vezes é mostrada como derivado da mesma necessidade 'humana' que a proibição contra o homicídio". 525

O enunciado do "dono de terras e escravos" permanece latente (e muitas vezes patente) em vários contextos das relações de trabalho. Exemplo que foi trazido nesse estudo é o da revista pessoal: como justificar a violação do direito à integridade física em nome do direito de proteção à propriedade dos produtos do estabelecimento?

\subsection{O poder da organização do trabalho versus liberdade do trabalhador: em busca da dignidade humana}

Em princípio, o Direito do Trabalho visa à igualdade e à segurança jurídicas das partes, em uma relação de elevada importância social: o contrato de trabalho. A segurança jurídica aqui traduzida não tem por sinônimo a permanência do status quo, porém objetiva assegurar, no âmbito das relações de trabalho subordinado, os valores e princípios insculpidos na constituição (entendida como momento de institucionalização) da sociedade.

Inicialmente, o trabalho é pensado como valor humano nos limites das expectativas depositadas pelo sistema econômico, ainda que isso não fosse claramente evidenciado em alguns discursos produzidos. A noção de dignidade no trabalho não se apresenta como fundamento nos moldes da Consolidação das Leis do Trabalho (CLT), cujo propósito é conter o exercício ilimitado do empregador no curso do contrato de trabalho subordinado. E só aparece na Constituição de 1967, que coincide com o momento em que o trabalhador brasileiro se depara com a dinâmica da organização taylorista-fordista.

A questão da dignidade desponta, pois, mais de vinte anos após a elaboração da CLT. A problemática amplia-se com a base principiológica contemplada pela Constituição Federal de 1988, em que resta patente a diferença entre a base da CLT e a da nova ordem constitucional.

Se o modelo, portanto, está inadequado e deve ser repensado à luz dos princípios da CF/88, como deve ser concebida a noção de trabalho? Propõe-se o trabalho como ação, de

\footnotetext{
${ }^{525}$ FROMM, Erich. Análise do homem, cit., p. 205.
} 
sorte que se enfatiza, conforme os ditames constitucionais, o seu valor humano. Reforça-se que a ação humana somente se vislumbra em um contexto de liberdade. Por conseguinte, se, no âmbito das relações de trabalho subordinado, houver constrangimento ou limitação à ação humana livre, não há trabalho digno.

O risco à saúde no campo social compromete a ordem pública, o que demanda do sistema jurídico a proposição de mecanismos de estímulo de condutas de promoção da dignidade humana, que fundamenta a constituição da sociedade. Com base na Constituição Federal de 1988, a ampliação conceitual dos agentes danosos à saúde e à vida do trabalhador tornar-se-ia uma questão de saúde pública.

Especificamente, lança-se luz ao impacto da organização de trabalho como agente promotor de danos à saúde e à vida do trabalhador. Ou seja, questiona-se a possibilidade de discutir a proteção à saúde e à segurança do trabalhador não apenas contra os agentes q uímicos, físicos e biológicos, mas também contra possíveis e eventuais danos decorrentes da relação interpessoal desenvolvida no ambiente de trabalho, destacadamente quanto aos aspectos organizacionais. Percorrer as origens dos riscos provocados pela organização de trabalho é tarefa preliminar para buscar soluções jurídicas que contenham as práticas lesivas aos trabalhadores.

O sistema jurídico laboral deve contemplar os elementos originários e desencadeadores das condutas contrárias à dignidade do trabalhador. Edith SeligmannSilva, médica psiquiatra e sanitarista, ao estudar a dimensão psíquica dos acidentes de trabalho, constatou que os aspectos organizacionais vinculados à determinação de acidentes de trabalho foram deliberadamente ignorados em grande parte das empresas. ${ }^{526}$ A autora também observou que, no âmbito da prevenção de acidentes, não eram considerados os impactos provocados por gestões autoritárias e formas de controle que infligiam medo aos trabalhadores, feriam a dignidade e causavam prejuízo à qualidade das comunicações e dos relacionamentos interpessoais. Da mesma forma, a cobrança por jornadas elastecidas (dimensão temporal do trabalho), incompatíveis com a fisiologia e com a natureza do trabalho mental, não era levada em consideração no momento de analisar o risco de acidente de trabalho. Edith Seligmann-Silva aponta para a fragilidade da

\footnotetext{
${ }^{526} \mathrm{O}$ texto a ser citado, montado para o Fórum de Saúde do Trabalhador, reúne alguns trechos e condensações de outros textos da autoria de Edith Seligmann-Silva - publicados e em publicação. São Paulo, abr. 2010. SELIGMANN-SILVA, Edith. [Textos]. Disponível em: $<$ http://www.moodle.fmb.unesp.br/file.php?file=\%2F52\%2FEncontros $\% 2$ F2010\%2FProducao_social_dos_ AT\%2FEdith_-_ACIDENTES_TRABALHO_PSIQUISMO.pdf>. Acesso em: 31 ago. 2010.
} 
integração dos Serviços Especializados em Saúde e Medicina do Trabalho (SESMTs) na dinâmica desses problemas organizacionais, dada a falta de canais de comunicação e o escasso entrosamento com áreas do comando administrativo. Segundo a autora,

os profissionais de Saúde e Segurança, na maioria das organizações brasileiras, ainda tem uma oportunidade muito reduzida de debater os aspectos da organização do trabalho e especialmente, os do controle gerencial - amplamente identificados como fonte de diferentes riscos, inclusive de riscos quanto a acidentes de trabalho e à saúde mental. ${ }^{527}$

Dessa forma, operam-se transformações organizacionais, com a introdução de inovações tecnológicas potencialmente agressivas à saúde mental, sem uma discussão prévia com profissionais habilitados para prever as consequências das mudanças.

A autora ressalta a tensão emocional e a insegurança promovidas pela precarização (fragilização) dos vínculos contratuais. A fragilidade dos vínculos contratuais "autoriza", na dinâmica das relações de trabalho, a intensificação do trabalho, exigência por polivalência, grande rotatividade interna, insuficiência de pausas e intervalos interjornadas. O resultado disso é a ruptura do referencial humano: quebra dos laços de companheirismo, prejuízo à cooperação e à comunicação entre os vários níveis da hierarquia e entre os próprios companheiros de trabalho. Edith Seligmann-Silva entende que esse cenário contribui para o aumento dos riscos de acidentes, principalmente em momentos críticos "nos quais a cooperação e comunicação são essenciais para impedir acidentes e catástrofes". 528

A somatória desses fatores leva ao medo do desamparo, que "sustenta a escalada da desestabilização psico-orgânica - que em geral é simultânea ao crescente isolamento social", o qual "é também, geralmente, isolamento afetivo e que atinge o âmbito familiar, alimentando o mal-estar". Por fim, a autora chega a uma conclusão que denota o distanciamento da concepção humana na esfera das relações de trabalho subordinado: "acrescemos que, sob as pressões da ideologia de excelência, - o cansaço se torna um verdadeiro tabu: mencionar a fadiga pode ser perigoso para a carreira e até para a manutenção do emprego". 529

\footnotetext{
${ }^{527}$ SELIGMANN-SILVA, Edith. op. cit.

${ }^{528}$ Id., loc. cit.

${ }^{529}$ Id., loc. cit.
} 
O desafio é que, enquanto a estrutura não é analisada, os problemas dessa natureza (estrutural) persistem e se avolumam. Na ausência de uma proposta de definição dos contornos estruturais da nova realidade, a solução jurídica, derivada do modelo de Estado Democrático de Direito, repousa na ampliação do alcance dos direitos sociais fundamentais. Quanto ao sistema juslaboral, o anacronismo da CLT frente à realidade atual gera a necessidade de se conceber a dinâmica complexa das relações e de poder no trabalho subordinado e confrontá-la ao engessamento da ordem jurídica positivada.

De acordo com a classificação de Walküre Lopes Ribeiro da Silva, a evolução do direito do trabalho no Brasil é marcada ideologicamente e apresenta quatro grandes etapas: a) pelo patriarcalismo e primórdios do liberalismo (até a Lei Áurea de 1888); b) pelo liberalismo (República Velha); c) pelo intervencionismo do tipo corporativista (da Revolução de 1930 até a Constituição de 1988); d) pelo questionamento do intervencionismo e intensificação de uma tendência flexibilizadora ou neoliberal (a partir da Constituição de 1988) ${ }^{530}$.

Dessa maneira, a legislação trabalhista que se extrai dos primórdios da legislação trabalhista brasileira ainda traz em seu bojo o conflito entre uma vocação liberal defendida pelas oligarquias econômicas e a necessidade de contenção do descontentamento social, que se sustenta na autoridade do corporativismo.

Na verdade, se é certo que as normas de proteção ao trabalhador originaram-se do clamor e do desconforto social, ainda mais inevitável é destacar a sua função na reprodução da ideologia de negação de conflitos, tão bem delineada na Encíclica Papal Rerum Novarum. A Carta Papal afasta a solução socialista de conflito de classes e prega a adoção de medidas prontas e eficazes em auxílio dos homens das classes inferiores, tendo em vista que estão, em sua maioria, numa situação de infortúnio e de miséria imerecida ${ }^{531}$.

\footnotetext{
${ }^{530}$ SILVA, Walküre Lopes Ribeiro da. Direito do trabalho brasileiro: principais aspectos de sua evolução histórica e as propostas de modernização. Revista do Tribunal Superior do Trabalho, Brasília, v. 69, n. 2, p. 121, jul./dez. 2003.

${ }^{531}$ PAPA LEÃO XIII. Rerum Novarum- Carta Encíclica de Sua Santidade o Papa Leão XIII sobre a condição dos operários. 12. ed. São Paulo: Paulinas, 2000. p. 10. Observa-se na Encíclica o firme propósito de oferecer uma alternativa à investida marxista. Justifica-se a assertiva ao identificar na Rerum Novarum a alternativa burguesa para combater o avanço do marxismo e o afluxo de movimentos sociais. A burguesia, inicialmente, apelou à Igreja Católica que, ao editar a Encíclica Rerum Novarum, previu direitos humanos como forma de conter os conflitos entre os grupos sociais. Por essa razão, o conteúdo da Encíclica repousa em um discurso contrário aos movimentos marxistas e socialistas, e tende a ser favorável à composição entre os atores sociais na busca de uma forma de convivência amistosa. Posteriormente, o Constitucionalismo Social institucionalizou os direitos humanos dos Trabalhadores de forma definitiva no seio estatal, o que neutralizou e retirou a força de alguns argumentos exarados pelos revolucionários.
} 
$\mathrm{Na}$ evolução do direito do trabalho no Brasil, o paradoxo de racionalidades resta patente no governo Vargas, como resultado de uma ordem jurídica que reconhece de modo paternalista numerosos direitos dos trabalhadores e que, ao mesmo tempo, domestica sindicatos, submetidos a um modelo de unicidade sindical $^{532}$.

A democracia brasileira é insculpida por uma atitude típica do temperamento nacional, descrita por Sérgio Buarque de Hollanda. Para o autor, os ideais da Revolução Francesa (dentre eles, liberdade e igualdade) estão associados à noção de bondade natural, incompatível com a "tese de uma humanidade má por natureza e de um combate de todos contra todos". O conflito, portanto, na óptica do "cordialismo", soa antipático e incômodo $^{533}$. Porém, os postulados francorrevolucionários são fruto de uma sociedade conflitual. Para manter a estabilidade do conjunto social, entendeu-se necessária no cenário nacional o ajuste da interpretação das "palavras mágicas Liberdade, Igualdade e Fraternidade" aos "nossos velhos padrões patriarcais e coloniais", de sorte que "as mudanças que inspiraram foram antes de aparato do que de substância" 534 .

Ainda que não seja a única explicação viável, pode-se asseverar que a afirmação de determinados direitos sociais aos trabalhadores foi um mecanismo para neutralizar o avanço dos conflitos. Pode-se concluir, ademais, que a constitucionalização de direitos sociais representou um instrumento de contenção de movimentos sociais contrários ao liberalismo econômico. Mas reforça-se que, de qualquer forma, ao contemplar os direitos

\footnotetext{
Afinal, o texto constitucional afirmava os direitos sociais. Logo, o Estado, como instituição ou estrutura social organizada, não os negava. No entanto, não se nega a importância da Carta Papal, em apresentar argumentos para a proteção do trabalho dos operários, das mulheres e das crianças, com base no fundamento da dignidade humana: "No que diz respeito aos bens naturais e exteriores, antes de tudo é um dever da autoridade pública subtrair o pobre operário à desumanidade de ávidos especuladores, que abusam, sem nenhuma discrição, das pessoas como das coisas. Não é justo nem humano exigir do homem tanto trabalho a ponto de fazer, pelo excesso de fadiga, embrutecer o espírito e enfraquecer o corpo. A atividade do homem, limitada como a sua natureza, tem limites que não se podem ultrapassar. O exercício e o uso aperfeiçoam-na, mas é preciso que, de quando em quando, se suspenda para dar lugar ao repouso. Não deve, portanto, o trabalho prolongar-se por mais tempo do que as forças permitem. Assim, o número de horas de trabalho diário não deve exceder à força dos trabalhadores, e a quantidade de repouso deve ser proporcionada à qualidade do trabalho, às circunstâncias do tempo e do lugar, à constituição e saúde dos operários. O trabalho, por exemplo, de extrair pedra, ferro, chumbo e outros materiais ocultos debaixo da terra, sendo mais pesado e nocivo à saúde, deve ser compensado com uma duração mais curta. Deve-se também atender às estações, porque não poucas vezes um trabalho que facilmente se suportaria numa estação, é de fato insuportável em outra, ou somente se vence com dificuldade". (PAPA LEÃO XIII. op. cit., p. 41-42).

${ }^{532}$ SILVA, Walküre Lopes Ribeiro da. op. cit., p. 126. "Unicidade sindical é a proibição, por lei, da existência de mais de um sindicato na mesma base de atuação. (...) A unicidade poderá significar, também, a proibição de mais de um sindicato da categoria". (NASCIMENTO, Amauri Mascaro. Compêndio de direito sindical. 2. ed. São Paulo: LTr, 2000. p. 158).

${ }^{533}$ HOLLANDA, Sérgio Buarque de. op. cit., p. 184.

${ }^{534}$ Id. Ibid., p. 179.
} 
sociais dos trabalhadores - isto é, os direitos de uma coletividade -, o Direito reconhece a complexidade social, marcada por conflitos, o que contradiz um modelo de racionalidade, em que todos os indivíduos exercem a autonomia da vontade com conhecimento pleno dos resultados, dos riscos e sempre maximizando seus interesses ${ }^{535}$. Exemplo disso são as normas de proteção à saúde e segurança ao trabalhador, que refletem a transformação de um modelo de homem abstrato (livre, igual e dotado de plena razão) para o modelo de sociedade de riscos, que pressupõe a ideia de ações individuais como geradoras de consequências que afetam toda a coletividade.

A legislação do trabalho deve refletir o curso de um processo democrático de apreensão dos elementos sociais de conflito, com vistas à minimização dos seus efeitos. Porém, dadas as características históricas do trabalho no Brasil, "a democratização em nosso país depende, nesse sentido, das possibilidades de mudança nos costumes - e nas 'mentalidades' - em uma sociedade tão marcada pela experiência do mando e do favor, da exclusão e do privilégio. A expectativa de mudança existe e se manifesta na exigência de direitos e de cidadania ativa(...).",536

A dignidade no trabalho esbarra, portanto, no sistema juslaboral modelado pelo corporativismo autoritário, conhecido como corporativismo estatal. Soma-se a essa base de organização da legislação trabalhista a influência do neocorporativismo. Conforme explica José Eduardo Faria, estabeleceu-se uma distinção entre o corporativismo de cunho autoritário, a exemplo do fascista, e os sistemas corporativos "pluralistas", os quais são resultantes de situações de mercado. São sistemas de representação de interesses das sociedades industriais, que acabam por impor limites e por fixar parâmetros à ação do Estado $^{537}$. Para José Eduardo Faria, o neocorporativismo é "sensível à diversidade e heterogeneidade de focos de interesse e de fontes de pressão existentes nas sociedades complexas". 538

\footnotetext{
535“"A organização social nunca está completamente imóvel: está em um constante processo de transformação". (PARETO, Vilfredo. Trasformazione della democrazia. Roma: Ed. Riuniti, 1999. p. 42). "Quanto ao reflexo desse cenário social na Constituição, ressalta Paulo Bonavides, "a Constituição do Estado social na democracia é a Constituição do conflito, dos conteúdos dinâmicos, do pluralismo, da tensão sempre renovada entre a igualdade e a liberdade, por isso mesmo, a Constituição dos direitos sociais básicos, das normas programáticas, ao contrário, portanto, da Constituição do Estado liberal, que pretendia ser a Constituição de repouso, do formalismo, da harmonia, da rígida separação de poderes, do divórcio entre o Estado e a Sociedade" (BONAVIDES, Paulo. op. cit., p. 380-381).

${ }^{536}$ BENEVIDES, Maria Victoria Mesquita. op. cit., p. 194.

${ }^{537}$ FARIA, José Eduardo. Direito e economia na democratização brasileira, cit., p. 135.

${ }^{538}$ Id. Ibid., p. 136.
} 
O neocorporativismo descrito por José Eduardo Faria apresenta-se, por exemplo, na forma de "redes elásticas", como denomina Richard Sennett. Elas se caracterizam por serem "mais abertas à reinvenção decisiva que as hierarquias piramidais, como as que governavam a era fordista". ${ }^{539} \mathrm{O}$ afastamento da rotina burocrática e o anseio por flexibilidade culmina em um sistema de poder que, segundo Sennett, se traduz por três elementos: "reinvenção descontínua de instituições; especialização flexível de produção; e concentração de poder sem centralização". 540

Sennett explica que as técnicas utilizadas para reinventar instituições compreendem programas de computador que padronizam procedimentos operacionais (SIMS), de tal sorte que uma empresa de grande porte pode monitorar a performance produtiva de todas as células e "eliminar rapidamente as unidades repetitivas e ineficientes". Prossegue Sennett: "essas mesmas maquetes de computador possibilitam aos contadores e planejadores industriais avaliar quantitativamente quais programas ou empregados podem ser cortados numa fusão de empresas" ${ }^{, 541}$

A segunda característica apontada por Sennett é a especialização flexível. Relacionada diretamente à alta tecnologia, exige do grupo de trabalho rápidas decisões, o que inviabiliza, portanto, uma organização de trabalho piramidal dependente da tomada de decisões pelo topo de uma hierarquia de comando. O elemento corrosivo da especialização flexível é a abertura dada para que as demandas do mundo externo determinem a estrutura interna das instituições. ${ }^{542}$ É sob esse novo modo produtivo que o trabalhador é conclamado a agir como Proteus, adaptando-se de forma acrítica às exigências do mercado.

Por fim, a terceira característica versa sobre a concentração de poder sem centralização de poder. Sennett destaca que, nessa forma de organização do trabalho, a dominação do alto mantém-se forte, não na forma de uma estrutura piramidal, mas sem um formato claro. Os SIMS, por exemplo, são instrumentos de controle que desagregam a estrutura hierárquica vertical, mas não descentralizam o poder, que permanece concentrado em uma estrutura complexa e sem forma. A liberdade para realizar a tarefa é falaciosa, porque o controle pode ser determinado pelas metas de produção, de lucro e de qualidade, cuja responsabilidade pelo atingimento fica a cargo do grupo de trabalho. Ou seja,

\footnotetext{
${ }^{539}$ SENNETT, Richard. A corrosão do caráter: consequências pessoais do trabalho no novo capitalismo. 14. ed. Trad. Marcos Santarrita. Rio de Janeiro: Record, 2009. p. 55.

${ }^{540}$ Id. Ibid., p. 54.

${ }^{541}$ Id. Ibid., p. 56.

${ }^{542}$ Id. Ibid., p. 60.
} 
transfere-se para o trabalhador a responsabilidade pelo resultado da exploração da atividade econômica. Assim, Richard Sennett explica, com base em Bennett Harrison, que "a estrutura permanece nas forças que impelem as unidades ou indivíduos a realizar; o que fica em aberto é como fazer isso, e o topo da organização flexível raras vezes oferece as respostas". 543

Esse quadro atinge a saúde mental do trabalhador. Edith Seligmann-Silva destaca quais seriam as origens e constituição do desgaste mental relacionado ao trabalho:

a) As relações sociais de trabalho e em sua vinculação à política de pessoal da empresa. A precarização dessas relações-no trabalho terceirizado, quarteirizado; nos contratos temporários e em outras modalidades de precarização, vem sendo correlacionada ao adoecimento mental, a acidentes do trabalho e diferentes tipos de adoecimento relacionados ao trabalho.

b) A organização formal do trabalho: incluindo o controle do trabalho prescrito, e, entre outros aspectos, a hierarquia e a divisão do trabalho, as tarefas designadas, as características temporais - duração das jornadas; horários de trabalho diurnos, noturnos ou regimes de turnos alternados; duração e frequencia das pausas; intensidade dos ritmos; além das formas de controle e avaliação instituídas.- que, em certas organizações, além de analisar atividades de trabalho, utilizam critérios de julgamento que são de ordem moral ou mesmo político-ideológico.

c) as atividades do trabalho real - e os esforços humanos que acarretam, descritos como cargas de trabalho físicas, cognitivas e psicoafetivas intimamente interrelacionadas; d) Os conteúdos significativos do trabalho 1) tendo em vista o contexto cultural envolvente em seus valores, e em tudo o que tenha relação com o reconhecimento social esperado pelo indivíduo trabalhador. Lembrando que prejuízos ao justo reconhecimento assumem relevância para a auto-imagem, identidade e saúde mental. 2) Considerando aspectos do histórico pessoal (biográfico, ocupacional e de saúde), gênero, sua inserção sócio-cultural e características psicológicas individuais - especialmente aspirações.

e) O ambiente físico, químico e biológico do trabalho, incluindo-se a análise das articulações deste com o meio ambiente em que decorre a vida exterior ao local de trabalho.

f) as relações interpessoais no trabalho e o modo como são vivenciadas.

Outros aspectos relevantes: Relações de poder ; comunicações; mudanças tecnológicas .Permeando os aspectos acima elencados, deve ser destacada a importância das relações de poder e das comunicações, assim como as repercussões derivadas do modo de introdução das mudancas tecnológicas. Estes aspectos, portanto, tem que ser considerados para pensar a prevenção e a promoção de saúde nos ambientes de trabalho. ${ }^{544}$

\footnotetext{
${ }^{543}$ SENNETT, Richard. op. cit., p. 64-65.

${ }^{544}$ SELIGMANN-SILVA, Edith. Origens e constituição do desgaste mental relacionado ao trabalho: contextos externos ao trabalho e contextos de trabalho. Texto síntese organizado e enviado pela Prof ${ }^{a}$ Edith Seligman. $\quad$ Mar. 2010.2 São Paulo. Disponível em: <http://www.moodle.fmb.unesp.br/file.php?file=\%2F52\%2FMateriais_e_links\%2FPublicacoes\%2FEdith_Selig man\%2FORIGENS_E_CONSTITUICAO_DO_DESGASTE_MENTAL.pdf>. Acesso em: 31 ago. 2010.
} 
Precarização, novas formas de organização de trabalho, relações de poder, carga de trabalho são elementos que não podem ser metrificados. E esse é o grande desafio do Direito do Trabalho: como estabelecer critérios que não possam ser objetivamente aferíveis. Como, por exemplo, um(a) Auditor(a)-Fiscal do Trabalho pode determinar que o empregador, embasado legalmente pelo jus variandi, não altere o horário de entrada de trabalho, em uma jornada diurna, dadas as peculiaridades de uma família chefiada por uma mãe solteira, com horários limitados para buscar os filhos na escola? Nessa sociedade complexa, a instabilidade das relações de trabalho prejudica a concretização da dignidade humana no mundo do trabalho, porque, mais uma vez na história das relações trabalhistas, ainda que assumindo contornos diversos, ocorre a desumanização do trabalho.

Trata-se do difícil desafio de superar a dominação do referencial burocrático, sem abandoná-lo como referência necessária para a organização racional da sociedade. Mais que um problema de forma, o desafio é modelar o conteúdo. Como já foi pontuado neste trabalho, um paradigma não é substituído totalmente por outro, pois as transformações não são estanques e determinadas - como se imaginava nos experimentos calcados nos pressupostos da física clássica -, e sim dinâmicas, respeitando a um processo. Convive-se com o risco já analisado: a presença de conceitos indeterminados, em uma ordem jurídica modelada pelo positivismo e, ainda mais nas relações de trabalho subordinado, corporativista, em que se acomoda o conflito, portanto não o admite claramente.

Exemplo da urgência do tema ora apresentado faz-se explícita na apresentação de projeto de lei em 28 de abril de 2010, em que se propõe a tratar o assédio moral como modalidade de acidente do trabalho. Nesse projeto de lei, em trâmite sob o n. 7.202/2010, está prevista a alteração no texto da alínea "b”, do inciso II, do artigo 21 da Lei n. 8.213, de 24 de julho de 1991:

Art. $1^{\circ} \mathrm{O}$ art. 21 da Lei $\mathrm{n}^{\circ} 8.213$, de 24 de julho de 1991, passa a vigorar com a seguinte redação:

"Art. 21

II - b) ofensa física ou moral intencional, inclusive de terceiro; ” (NR)

A justificativa para a alteração na redação do referido dispositivo legal, ampliando o conceito de acidente de trabalho, está no fato de o assédio moral constituir-se cada vez mais como fator de risco nos ambientes de trabalho. Embora não seja algo novo, destacam os mencionados deputados que atualmente ocorre uma "intensificação e banalização do 
fenômeno e novas abordagens do problema tentam estabelecer o nexo causal com a organização do trabalho e tratá-lo como ligado ao trabalho". Enfatiza-se ainda na justificativa do projeto de lei que, por ser uma violência psicológica, pode causar danos à saúde física e mental, "não somente daquele que é atingido, mas de todo o coletivo que testemunha esses atos". 545

A CLT, na esteira do que propõe Teubner na teoria do Direito dos conflitos, teria de refletir o jogo entre as referências praticadas no cenário das relações de trabalho subordinado, em que se destacam os pontos de observação do empregador e do empregado, e traduzi-las em uma forma 'constitucional', especificamente em termos de dignidade do trabalhador. O Direito, como enfatiza Teubner, corre o risco de perder suas virtudes “politeístas”, em nome de um "deus único". Isso ocorre quando o Direito se atém à racionalidade particularística de um setor da sociedade. Mas, ao proceder dessa forma, o Direito pode infligir danos aos outros setores sociais.

Visto dessa forma, Teubner conclui para afirmar que a revisão da legislação sob o prisma constitucional pode ser considerado um serviço ao "politeísmo". 546 Assim, compreender-se-ia no processo dinâmico das relações de trabalho subordinado o referencial de ação humana e o trabalho seria contemplado como processo que envolve o ser humano em sua integralidade, como ser físico-biológico e pensante. E o politeísmo, a que se refere Teubner, corresponde à pluralidade e à complexidade presente nas várias esferas da sociedade, incluindo a do trabalho.

Isso implica a ampliação e reformulação conceitual. Arnaldo Süssekind ressalta que "a época em que a vigente legislação do trabalho foi implantada coincide com a fase de ditadura que a história identifica como Estado Novo (1937-1945)". 547 As características autoritárias, dessa forma, fazem-se presentes no contéudo da CLT. Süssekind destaca que o texto da CLT foi modelado em obediência ao postulado básico do corporativismo: "a superação da luta de classes pela colaboração entre a força de trabalho e o capital, 'no esforço espontâneo de realizar a grandeza nacional"," ${ }^{548}$ Sendo assim, "a absorção do indivíduo pelo Estado, a eliminação da consciência das classes, a subordinação dos corpos sociais intermediários à autoridade central, a incorporação da ordem econômica à esfera de

\footnotetext{
${ }^{545}$ CÂMARA DOS DEPUTADOS. Projeto de Lei n. 7.202/2010. Disponível em: $<$ http://www.camara.gov.br/sileg/integras/761349.pdf>. Acesso em: 22 out. 2010.

${ }^{546}$ TEUBNER, Gunther. Altera pars auditur: law in collision of discourses, cit., p. 173.

${ }^{547}$ SÜSSEKIND, Arnaldo. Direito do trabalho: temas em aberto. São Paulo: LTr, 1998. p. 54.

${ }^{548}$ Id. Ibid., p. 61-62.
} 
intervenção do Estado, a supressão da autodefesa dos interesses profissionais (proibição da greve), o fracasso prático na implementação das convenções coletivas de trabalho e a presença arbitral do Estado no campo dos conflitos coletivos" ${ }^{549}$ parametrizaram o texto consolidado.

Além do viés corporativista, a CLT destinava-se a disciplinar as relações de trabalho subordinado, de acordo com o modelo de organização e produção de sua época. $\mathrm{O}$ conceito de trabalhador da CLT, por exemplo, foi modelado com base na noção de operário. Hoje a classe trabalhadora incorpora "tanto os trabalhadores materiais como aqueles e aquelas que exercem trabalho imaterial, predominantemente intelectual. ${ }^{550}$

Com relação às causas de acidente de trabalho, a estrutura hierárquica rígida e o autoritarismo presentes nas relações de trabalho no Brasil culminam na imposição da culpa, em grande número de casos, às vítimas dos acidentes de trabalho, mesmo quando fica claro que estão presentes situações evidentes de risco no meio ambiente do trabalho ${ }^{551}$. A conclusão pela culpa da vítima resulta em "um modelo conveniente e útil para a descaracterização da culpa do empregador ou de seus prepostos, mantendo-se deste modo um clima de impunidade em relação aos acidentes de trabalho" ${ }^{\text {"552. }}$.

Ildeberto Muniz de Almeida lembra que as conclusões das análises de acidentes do trabalho, tradicionalmente, atribuem a culpa às próprias vítimas, ao invés de constatar a existência de problemas ou disfunções nos sistemas que causam os acidentes ${ }^{553}$. A razão para essa tendência está na adoção de um modelo tradicional de análise de acidentes, que

\footnotetext{
${ }^{549}$ SÜSSEKIND, Arnaldo. op. cit., p. 61.

${ }^{550}$ ANTUNES, Ricardo. Dimensões da precarização estrutural do trabalho. In: DRUCK, Graça; FRANCO, Tânia. A perda da razão social do trabalho: terceirização e precarização. São Paulo: Boitempo, 2007. p. 21

${ }^{551}$ VILELA, Rodolfo Andrade Gouveia et al. Culpa da vítima: um modelo para perpetuar a impunidade nos acidentes de trabalho. Caderno de Saúde Pública, Rio de Janeiro, v. 20, n. 2, p. 576, mar./abr. 2004.

${ }^{552}$ Id. Ibid., p. 578. Um exemplo recente de atribuição de culpa à vítima é o de um jovem, contratado para a função de auxiliar de produção, iniciou as atividades laborais na empresa Produtos Alimentícios Cadore S.A., em São João de Meriti, no Rio de Janeiro. Embora contratado para ser auxiliar de produção, trabalhou todo o tempo como operador de máquina e alega o trabalhador que nunca recebeu treinamento para o exercício de tal atividade. Em 17 de agosto de 2010, o jovem teve seu braço amputado por um triturador de macarrão. A diretora-administrativa da empresa, Cláudia Estefano, alegou que o triturador "não é uma máquina para ser operada e não precisa de parâmetros para funcionar", pois só tem o botão liga/desliga. A mesma diretora entrou em contato com o encarregado do setor e foi informada, segundo ela e de acordo com o encarregado do setor, que o acidente foi provocado por uma imprudência do rapaz. TABAK, Bernardo. Jovem que perdeu braço em triturador diz que não recebeu treinamento. G1 RJ. Disponível em: $<$ http://g1.globo.com/rio-de-janeiro/noticia/2010/08/operario-que-perdeu-o-braco-em-fabrica-de-massasdeixa-hospital.html>. Acesso em: 25 ago. 2010.

${ }^{553}$ ALMEIDA, Ildeberto Muniz. Abordagem sistêmica de acidentes e sistemas de gestão de saúde e segurança do trabalho. INTERFACEHS: revista de gestão integrada em saúde do trabalho e meio ambiente, São Paulo, $\begin{array}{llllll}\mathrm{v} . & \mathrm{n} & 2, & 2006 . & \text { Disponível } & \text { em: }\end{array}$ <http://www.interfacehs.sp.senac.br/br/artigos.asp?ed=2\&cod_artigo=32. Acesso em: 20 ago. 2010.
} 
repercute diretamente na avaliação da responsabilidade civil e penal e da eventual condenação por danos ao empregado acidentado. A tendência, nessa hipótese, é atribuir ao Estado os custos com a recuperação do trabalhador Esse modelo baseia-se na unicausalidade, ou seja, não avalia a complexidade das relações de trabalho subordinado, em que se destaca o exercício do poder como determinante para a dinâmica do processo produtivo.

O modelo unicausal corresponde ao paradigma racional científico. Em nome da redução da complexidade, restringe a análise do acidente à determinação da causa para compreender o efeito causado. Com base nesse modelo, não se considera a interação do indivíduo (trabalhador) com os demais elementos envolvidos na relação de trabalho, de forma que os acidentes são derivados de fatores técnicos ou de fatores humanos. Os fatores técnicos, em análises de acidentes de trabalho, são identificados como condições materiais inseguras, enquanto os fatores humanos são compreendidos como comportamentos inseguros adotados pelo trabalhador. Esse modelo de referência para observação do acidente de trabalho desconsidera que o trabalhador não realiza sua atividade com liberdade de escolha. Os meios, os objetivos e as metas de produção são previamente determinados pelas chefias, que definem prescrições, horários, a divisão dos trabalhadores para a realização das tarefas ${ }^{554}$.

As novas formas de organização de trabalho não afastaram os riscos para a saúde e a vida do trabalhador. O que se observa, contudo, é uma alteração na natureza dos danos, com a potencialização dos danos à saúde psíquica. Isso é decorrência das mudanças no quadro das atividades econômicas e do perfil do empregado no Brasil, desde a elaboração da CLT.

Com base no recenseamento realizado em 1940 pelo Instituto Brasileiro de Geografia e Estatística, 9.453.512 de brasileiros ainda se dedicavam à atividade da agricultura, pecuária e silvicultura, contra 1.400.056, cuja atividade principal era desenvolvida na indústria de transformação ${ }^{555}$.

\footnotetext{
${ }^{554}$ ALMEIDA, Ildeberto Muniz de. Construindo a culpa e evitando a prevenção: caminhos da investigação de acidentes do trabalho em empresas de município de porte médio. Tese (Doutorado) - Departamento de Saúde Ambiental da Faculdade de Saúde Pública, Universidade de São Paulo, São Paulo, 2001. p. 33.

${ }^{555}$ INSTITUTO BRASILEIRO DE GEOGRAFIA E ESTATÍSTICA - IBGE. Recenseamento Geral do Brasil ( $1^{\circ}$ de setembro de 1940). Censo Demográfico - População e Habitação. Quadros de totais para o conjunto da União e de distribuição pelas regiões fisiográficas e unidades federadas. Série Nacional. Rio de Janeiro: Serviço Gráfico do Instituto Brasileiro de Geografia e Estatística, 1950. v. 2, p. 6.
} 
A economia brasileira sofre mudança a partir das décadas de 1940 e 1950 . Segundo relata Marcelo de Paiva Abreu,

O Brasil deixou de ser um país agrícola: a partir do início do século a participação da agricultura no PIB, a preços de 1949 , caiu de $44,6 \%$ do PIB para $38,1 \%$ em 1920, 29,4\% em 1940, 16,9\% em 1960 e $9,8 \%$ em 1980, permanecendo aproximadamente estável desde então. Paralelamente à contração da agricultura, cresceu a participação da indústria : 11,6\% do PIB em 1900, 15,7\% em 1920, 18,7\% em 1940, $29,9 \%$ em 1960, 34,4\% em 1980. Depois de meados da década de 1980, a exemplo de outras economias mais maduras, esta participação começou a declinar até alcançar $27,7 \%$ em $2000 .{ }^{556}$

A queda da participação da indústria como principal atividade econômica resulta da introdução de novas tecnologias, que alteraram o modo de produção e de gestão de pessoas. Conforme relatou o DIESAT (Departamento Intersindical de Estudos e Pesquisas de Saúde e dos Ambientes de Trabalho), em seu Anuário Estatístico de Acidentes de Trabalho de 2008,

A adoção de novas tecnologias e métodos gerenciais facilita a intensificação do trabalho que, aliada à instabilidade no emprego, modifica o perfil de adoecimento e sofrimento dos trabalhadores, embora as inovações tecnológicas tenham reduzido a exposição a alguns riscos ocupacionais em determinados ramos de atividade, contribuindo para tornar o trabalho nesses ambientes menos insalubre e perigoso, constatase que, paralelamente, outros riscos são gerados. A difusão dessas tecnologias avançadas na área da química fina, na indústria nuclear e nas empresas de biotecnologia que operam com organismos geneticamente modificados, nanotecnologia, por exemplo, acrescenta novos e complexos problemas para o meio ambiente e a saúde pública do país. ${ }^{557}$

O Ministério da Previdência Social registrou, em 2007,

"653.090 acidentes e doenças do trabalho, entre os trabalhadores assegurados da Previdência Social. Observem que este número, que já é alarmante, não inclui os trabalhadores autônomos (contribuintes individuais) e as empregadas domésticas. Estes eventos provocam enorme impacto social, econômico e sobre a saúde pública no Brasil. Entre esses registros contabilizou-se 20.786 doenças relacionadas ao trabalho, e parte destes acidentes e doenças tiveram como conseqüência o afastamento das atividades de 580.592 trabalhadores devido à

\footnotetext{
${ }^{556}$ BRASIL. MINISTÉRIO DO PLANEJAMENTO, ORÇAMENTO E GESTÃO. INSTITUTO BRASILEIRO DE GEOGRAFIA E ESTATÍSTICA - IBGE. Estatísticas do século XX. Rio de Janeiro. Disponível em: <http://www.ibge.gov.br/seculoxx/seculoxx.pdf>. Acesso em: 23 nov. 2010.

${ }^{557}$ DEPARTAMENTO INTERSINDICAL DE ESTUDOS E PESQUISAS DE SAÚDE E DOS AMBIENTES DE TRABALHO - DIESAT. Anuário Estatístico de Acidentes de Trabalho. Disponível em: <http: //www.diesat.org.br/artigos/AEAT08.PDF>. Acesso em: 24 nov. 2010.
} 
incapacidade temporária (298.896 até 15 dias e 281.696 com tempo de afastamento superior a 15 dias), 8.504 trabalhadores por incapacidade permanente, e o óbito de 2.804 cidadãos. Para termos uma noção da importância do tema saúde e segurança ocupacional basta observar que no Brasil, em 2007, ocorreu cerca de 1 morte a cada 3 horas, motivada pelo risco decorrente dos fatores ambientais do trabalho e ainda cerca de 75 acidentes e doenças do trabalho reconhecidos a cada 1 hora na jornada diária. Em 2007 observamos uma média de 31 trabalhadores/dia que não mais retornaram ao trabalho devido a invalidez ou morte. Se considerarmos exclusivamente o pagamento, pelo INSS, dos benefícios devido a acidentes e doenças do trabalho somado ao pagamento das aposentadorias especiais decorrentes das condições ambientais do trabalho em 2008, encontraremos um valor da ordem de $\mathrm{R} \$ 11,60$ bilhões/ano. Se adicionarmos despesas como o custo operacional do INSS mais as despesas na área da saúde e afins o custo - Brasil atinge valor da ordem de $\mathrm{R} \$ 46,40$ bilhões. ${ }^{558}$

No mesmo estudo encampado pelo DIESAT, foi apontado que, desde 1970, mais de 30 milhões de acidentes foram notificados no Brasil, sem contar os 100 mil óbitos entre trabalhadores jovens e produtivos. Outro dado alarmante é o aumento do número de acidentes em 2008 (747.663 acidentes de trabalho no Brasil), com custo ao país de cerca de $\mathrm{R} \$ 42$ bilhões por ano, o que representa aproximadamente o equivalente a 4,7\% do Produto Interno Bruto - PIB. ${ }^{559} \mathrm{O}$ número de acidentes registrado a partir de 2007 contraria um período de relativa constância evolutiva na escala de crescimento de acidentes e doenças do trabalho. O gráfico 1 apresenta o quadro evolutivo da quantidade de acidentes de trabalho registrados no Brasil, no período de 1970-2008.

O aumento do registro do acidentes do trabalho, a partir de 2007, está relacionado com a adoção do Nexo Técnico Epidemiológico Previdenciário - NTEP. Trata-se do cruzamento das informações de código da Classificação Internacional de Doenças - CID10 e de código da Classificação Nacional de Atividade Econômica - CNAE, com vistas a apontar a existência de relação entre a lesão ou agravo e a atividade desenvolvida pelo trabalhador, embasada em estudos científicos baseados nos fundamentos da estatística e epidemiologia. ${ }^{560}$

\footnotetext{
${ }^{558}$ BRASIL. MINISTÉRIO DA PREVIDÊNCIA SOCIAL. Informações Estatísticas Relativas à Segurança e Saúde Ocupacional, cit.

${ }^{559}$ DEPARTAMENTO INTERSINDICAL DE ESTUDOS E PESQUISAS DE SAÚDE E DOS AMBIENTES DE TRABALHO - DIESAT. Anuário Estatístico de Acidentes de Trabalho, cit.

${ }^{560}$ BRASIL. MINISTÉRIO DA PREVIDÊNCIA SOCIAL. Informações Estatísticas Relativas à Segurança e Saúde Ocupacional, cit.
} 


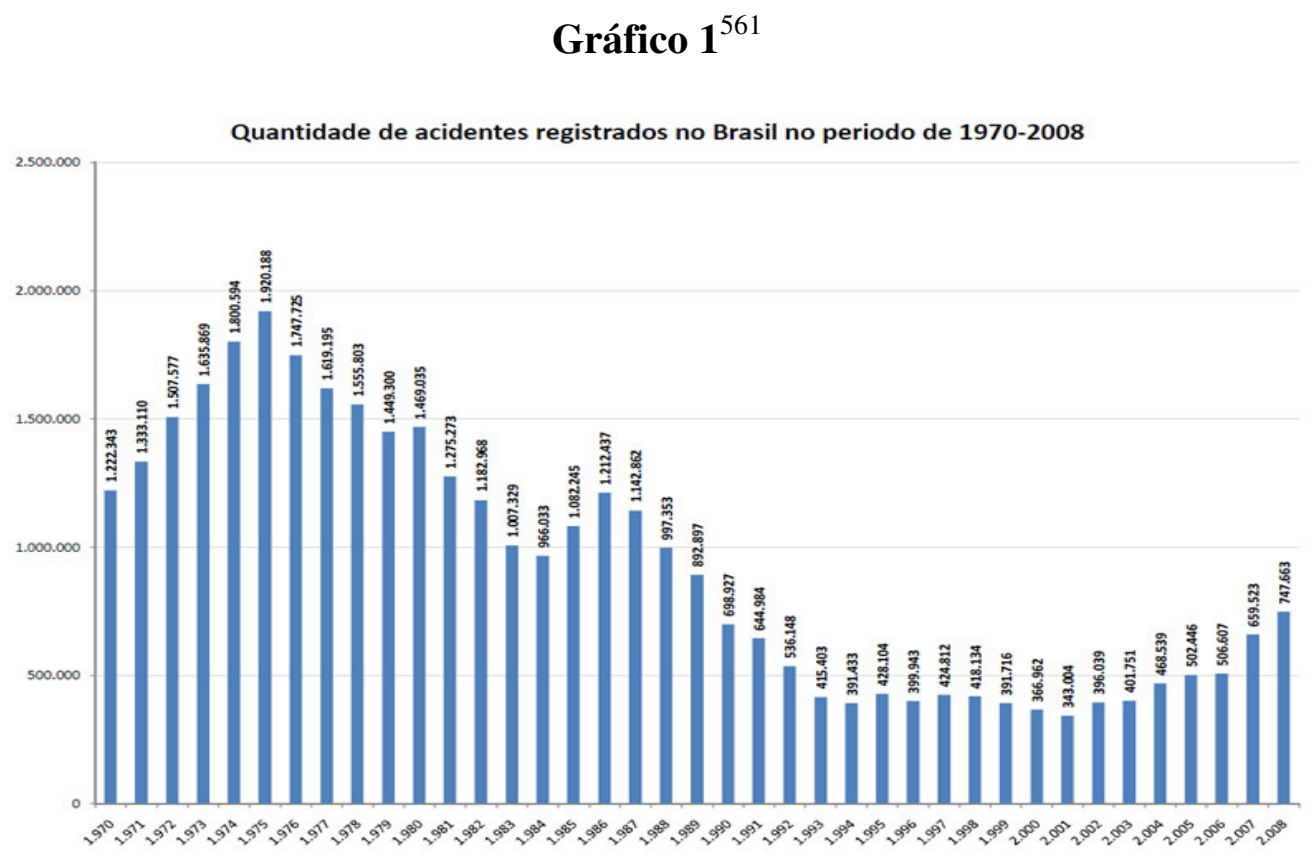

Introduzido em 2007, permitiu ao trabalhador a solicitação do benefício previdenciário, em razão de acidente do trabalho, sem condicionar tal requerimento à emissão da comunicação de acidente do trabalho (CAT). Conforme já foi mencionado, o incremento na concessão de benefícios na ordem de 148\%, após a introdução do NTEP, permitiu concluir que havia um mascaramento na notificação de acidentes e doenças do trabalho. ${ }^{562}$

O que chama a atenção, portanto, é a ausência de uma clara noção dos riscos das novas atividades, dos novos modos de produção e de gestão. Exemplo disso, são os impactos psicológicos sobre o trabalho, os quais não podem ser mensurados com base em um padrão objetivo, ou seja, fogem à racionalidade técnico-científica, que caracteriza a proteção do trabalho contra os agentes químicos, físicos e biológicos. As doenças relacionadas ao estresse e à fadiga física e mental podem culminar até mesmo no suicídio ou tentativa de suicídio no ambiente de trabalho, fenômeno esse que apareceu na maioria dos países ocidentais nos anos $1990 .^{563}$

\footnotetext{
${ }^{561}$ BRASIL. MINISTÉRIO DA PREVIDÊNCIA SOCIAL. Informações Estatísticas Relativas à Segurança e Saúde Ocupacional, cit.

${ }^{562}$ Id., loc. cit.

${ }^{563}$ DEJOURS, Christophe; Florence Bègue. Suicídio e trabalho: o que fazer? Trad. Franck Soudant. Brasília: Paralelo 15, 2010. p. II.
} 
Nota-se que todas essas mudanças promovidas no quadro das relações de trabalho subordinado acentuaram-se na década de 90, com a intensificação dos efeitos da globalização no cenário econômico nacional e do discurso da flexibilização da legislação do trabalho. O perfil do trabalhador, então, é remodelado, de acordo com as novas formas e demandas da organização do trabalho. As lesões por esforço repetitivo (LER) ${ }^{564}$, por exemplo, embora secularmente conhecidas, tornaram-se frequentes exatamente na década de 90. O grupo de risco concentra-se, segundo o DIESAT, nos bancários, metalúrgicos, operadores de telemarketing, comerciários e trabalhadores de tecnologia da informação, ainda que essas lesões sejam constatadas em quase todos os setores econômicos. ${ }^{565}$

Avaliar essa realidade depende da concepção de trabalho como ação humana, em um cenário de "complexidade organizada":

A complexidade organizada provoca novas funções e novas contradições nas relações de trabalho (...) as mudanças profundas que ocorrem no desenvolvimento técnico-científico desde meados do século XX afetam, reestruturam e contextualizam não só as relações de produção, mas também as relações de dominação de trabalhadores e de povos, assim como as relações de repressão e de mediação. ${ }^{566}$ [grifo nosso]

Resta patente a constatação feita por Stephen Holmes e Cass R. Sunstein: "Somente as liberdades que são valiosas na prática emprestam legitimidade para uma ordem política liberal". 567 O sistema capitalista liberal depende da garantia das liberdades. Por conseguinte, o comportamento do homos economicus deve estar amparado pelo referencial normativo que assegura a liberdade. Resgata-se aqui a noção de trabalho como ação humana, de tal sorte que garantir a liberdade do trabalhador é promover-lhe a possibilidade de agir. Por essa razão, trabalho digno depende de um cenário de liberdade, a ser construído na forma de um sistema de relações de trabalho subordinado que seja organizado com base no referencial constitucional de melhoria das condições de vida do trabalhador.

Interessante notar que, mesmo baseado somente em uma análise financeira, os custos da violência no local de trabalho mostram a ineficiência do modelo. Richard Sennett

\footnotetext{
${ }^{564}$ Doenças causadas por esforço repetitivo. Exemplo: tenossinovite, tendinite, bursite.

${ }^{565}$ DEPARTAMENTO INTERSINDICAL DE ESTUDOS E PESQUISAS DE SAÚDE E DOS AMBIENTES DE TRABALHO - DIESAT. Anuário Estatístico de Acidentes de Trabalho, cit.

${ }^{566}$ GONZÁLEZ CASANOVA, Pablo. op. cit., p. 65.

${ }^{567}$ HOLMES, Stephen; SUNSTEIN, Cass R. op. cit., p. 20.
} 
descreve que, no início dos anos 90, a Associação Americana de Administração e as empresas Wyatt avaliaram o resultado das empresas que enxugaram os seus quadros e replanejaram o seu modo de produção, ou seja, adotaram o modelo conhecido por "reengenharia". Segundo a Associação Americana de Administração, as reduções do quadro de pessoal geraram "lucros mais baixos e declínio de produtividade do trabalhador". A análise das empresas Wyatt, por sua vez, permitiu extrair que "menos da metade das empresas atingiu as metas de redução de despesas; menos de um terço aumentou a lucratividade". Sennett conclui que os motivos desse fracasso são evidentes: o moral e a motivação dos trabalhadores descresceram nos vários arrochos de redução, pois os "trabalhadores sobreviventes ficaram mais à espera do próximo golpe de machado que exultantes com a vitória competitiva sobre os demitidos". 568 Ainda mais significativa é a conclusão de alguns economistas que, segundo Richard Sennett, "têm mesmo afirmado que, quando se somam todos os custos do trabalho computadorizado, a tecnologia se mostrou de fato um déficit de produtividade". 569

Não se desconsidera a importância dos custos em uma sociedade capitalista, mas outros fatores devem ser considerados no momento de estabelecer a abordagem juslaboral. Manter um meio ambiente saudável que é prejudicial à saúde do trabalhador, adotado um enfoque mais amplo, complexo e sistêmico, extrapola a análise restrita dos custos econômicos e contesta sua viabilidade. Questões como garantir uma mão-de-obra saudável e a baixa taxa de natalidade, que compromete o percentual de trabalhadores jovens no futuro do mercado de trabalho, devem ser consideradas. Trata-se, enfim, de uma questão de saúde e política públicas, ou seja, de ordem pública. Por esse motivo, a noção de eficiência deve partir de uma perspectiva complexo-sistêmica. Assim, "a dependência da proteção dos direitos por meio de recursos privados é bem compreendida e tem tradicionalmente atraído maior atenção do que a dependência da proteção dos direitos pelos recursos públicos". 570

O sistema juslaboral deve reconhecer a dinâmica da relação de trabalho subordinado e os modelos empregados para apreciação dos fenômenos dela decorrentes. A

\footnotetext{
${ }^{568}$ SENNETT, Richard. A corrosão do caráter: consequências pessoais do trabalho no novo capitalismo, cit., p. 58. ${ }^{569}$ Id., loc. cit.

${ }^{570}$ HOLMES, Stephen; SUNSTEIN, Cass R. op. cit., p. 21. Stephen Holmes e Cass R. Sunstein citam que “os advogados que trabalham o American Civil Liberties Union voluntariamente aceitam uma redução nos rendimentos pessoais a fim de defender o que eles consideram como direitos fundamentais". (Id., loc. cit.).
} 
insuficiência do modelo unicausal, por exemplo, clama por uma nova perspectiva para a abordagem do acidente de trabalho.

Propõe-se, assim, a expansão para uma visão sistêmica ou multicausal, em que se agregam novos elementos de análise, “deslocando da ênfase do subsistema homeminstrumento de trabalho, para a interação desse subsistema com o ambiente organizacional, reconhecendo dessa forma o intricado relacionamento homem-ambiente". ${ }^{571}$ Sob essa óptica sistêmica, considera-se que os atos inseguros são consequências de outros fatores, e não as causas únicas para a ocorrência do acidente.

Inevitavelmente, os problemas existentes nas relações de trabalho acabam por repercutir além dos muros das empresas. A onda de suicídios na França é um exemplo recente dos danos sociais que uma organização de trabalho, focada precipuamente em resultados calculáveis e objetivos, pode causar. Lei de 2002 sobre a modernização social que introduziu um capítulo sobre o assédio moral e tipificou o assédio moral no Código Penal:

\begin{abstract}
Artigo 222-33-2
Redação dada pela Lei n²002-73, de 17 de janeiro de 2002

$\mathrm{O}$ fato de assediar outrem por meio de condutas repetidas, tendo por objeto ou por efeito uma degradação das condições de trabalho, suscetível de trazer dano a seus direitos ou à sua dignidade, de alterar sua saúde física ou mental ou comprometer seu desenvolvimento profissional. Pena de um ano de prisão e 15.000 euros de multa. ${ }^{572}$
\end{abstract}

\footnotetext{
${ }^{571}$ MUNHÊ, Vilma Pimenta Cirilo. Análise multicausal para a compreensão de acidentes de trabalho: um estudo de caso de uma empresa paranaense de alimentos. 2009. Dissertação (Mestre em Administração) Universidade Federal do Paraná, Curitiba, 2009. p. 26. A autora apresenta em sua dissertação um quadro bastante elucidativo acerca da diferença de perspectiva entre o modelo unicausal e o modelo multicausal (sistêmico):

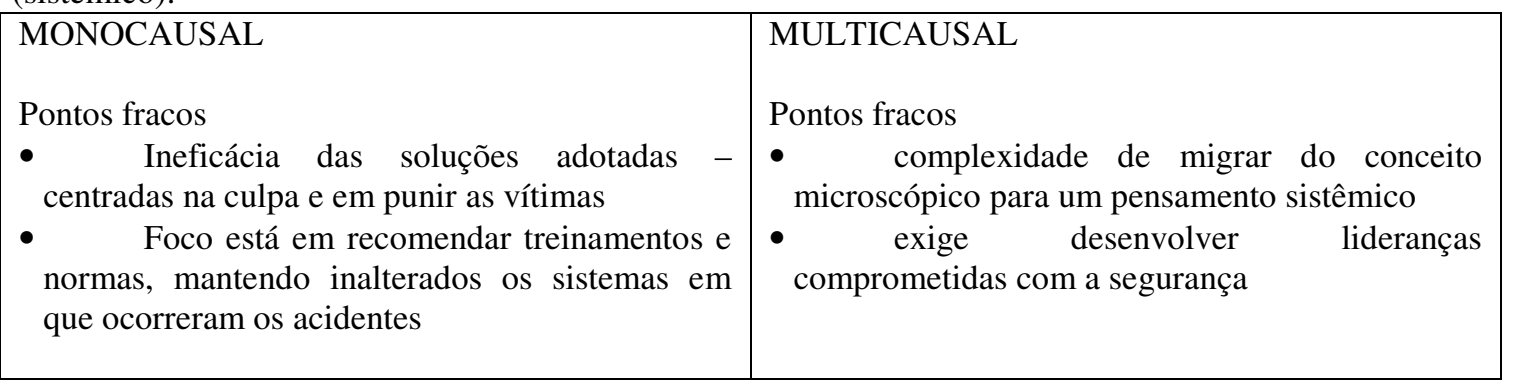

(Id. Ibid., p. 123).

${ }^{572}$ No Brasil, já existe norma penal tipificando o assédio sexual, expressamente mencionando a hipótese do fato ilícito ocorrer na esfera de trabalho: "Art. 216-A. Constranger alguém com o intuito de obter vantagem ou favorecimento sexual, prevalecendo-se o agente da sua condição de superior hierárquico ou ascendência inerentes ao exercício de emprego, cargo ou função. Pena detenção, de 1 (um) a 2 (dois) anos." BRASIL. Lei n. 10.224, de 15 de maio de 2001. Altera o Decreto-Lei no 2.848, de 7 de dezembro de 1940 - Código Penal, para dispor sobre o crime de assédio sexual e dá outras providências. Disponível em: <http://www.planalto.gov.br/ccivil/LEIS/LEIS_2001/L10224.htm>. Acesso em: 20 nov. 2010.
} 
O sistema jurídico opera nesse cenário, em que existem, por um lado, as pressões estruturais, por outro, a falta de elementos jurídicos para sustentar a proposta de um novo modelo de análise da relação de trabalho subordinado, plenamente adaptado ao sistema constitucional implantado em 1988, fundamentado na dignidade humana.

A proposta é contemplar essa dinâmica organizacional da relação de trabalho como objeto de disciplina juslaboral, para garantir a dignidade do trabalho e evitar riscos de danos psíquico-biológicos ao trabalhador, em decorrência de mudanças conjunturais. Ou seja, é preciso readaptar a estrutura sistêmica juslaboral à nova realidade do mundo do trabalho e não submetê-la a alterações conjunturais (flexibilização ou desregulamentação) que comprometem a integridade do sistema e desestabilizam as relações, que se tornam ineficientes. No caso das formas de organização do trabalho, é importante partir da premissa de que não há técnica absolutamente eficiente, com base somente em dados objetivos. A organização do trabalho deve combinar eficiência e, prioritariamente, a dignidade do trabalhador. Nessa seara, a função do Direito não pode ser mais traduzida na tarefa de "reconstituir a unidade perdida da sociedade, mas designar os contornos das identidades plurais, protegê-las contra a dominação de outros discursos e limitar os danos provocados pela precipitação das colisões de discursos". 573

A valorização do trabalho além de sua perspectiva como fator de produção não é uma realidade que se extrai facilmente. Há de se embrenhar na seara das bases do constitucionalismo para promover e justificar o discurso sobre a dignidade do trabalhador, como valor humano aclamado pela sociedade. Desse modo, a questão, segundo Gunther Teubner, não é mais se o Direito trata os iguais de forma igual e os desiguais no limite de sua desigualdade, mas se o "Direito promove a justiça para os outros discursos nos próprios termos desses". Ou seja, não se trata mais de compensar os desníveis, mas buscar argumentos que alcancem a estrutura da sociedade complexa e que promovam a justiça e a dignidade nos termos previstos na Constituição.

Busca-se, pois, repensar o paradigma de conhecimento e as suas fragilidades: reconhecer a pluralidade e, a partir disso, minimizar os problemas dela decorrentes. Diferentemente do modelo anterior, em que se reduz a complexidade, isolando o objeto de conhecimento. Um novo enfoque demanda uma análise interdisciplinar, a qual, no que

${ }^{573}$ TEUBNER, Gunther. Altera pars auditur: law in collision of discourses, cit., p. 175. 
tange as relações de trabalho, compreende em primeiro plano o universo do empregador, do empregado e da atuação estatal:

A interdisciplina, como relação entre várias disciplinas em que se divide o saber-fazer humano, é uma das soluções que se oferecem a um problema muito mais profundo, como a unidade do ser e do saber, ou a unidade das ciências, das técnicas, das artes e das humanidades com o conjunto cognoscível e construível da vida e do universo. ${ }^{574}$

A redefinição de conceitos e de institutos, com base na realidade das relações de trabalho subordinado, faz-se, pois, imprescindível, a fim de garantir a dignidade do ser humano nas relações de trabalho subordinado. É preciso ir além da técnica e da utilidade das coisas, para não se aproximar da imagem de Hefestos: capaz de criar a mais bela tecnologia, mas sem condições de transformar-se a si próprio.

Para Jung, é de "fundamental importância viver a experiência da ambivalência humana, não para eliminá-la, mas para 'unir os opostos' num plano mais elevado". ${ }^{575}$ Nas relações de trabalho, a experiência da ambivalência humana corresponderia ao fato de o ser humano identificar em si-mesmo o detentor do poder (patrão/empregador) e o submisso (operário/empregado). O homem possui esses “opostos”, essas duas potências, ainda que uma se apresente em estado latente. ${ }^{576}$

O homem não visa tão-somente à sua sobrevivência. Há vontade de poder, ou seja, de desenvolver potencialidades. Ao criticar os fisiólogos e consequentemente o tecnicismo que florescia, Nietzsche escreveu:

Uma criatura viva quer antes de tudo dar vazão a sua força - a própria vida é vontade de poder -: a autoconservação é apenas uma das indiretas, mais freqüentes conseqüências disso. ${ }^{577}$

A sociedade capitalista de consumo alimenta no indivíduo a ideia de que a propriedade ("ter") pode ser conquistada por qualquer um. Introduz o seu modelo de ambivalência: o indivíduo como vendedor e mercadoria. Na condição de vendedor, o

\footnotetext{
${ }^{574}$ GONZÁLEZ CASANOVA, Pablo. op. cit., p. 13.

${ }^{575}$ GUGGENBÜHL-CRAIG, Adolf. op. cit., p. 125.

576، A diversidade dos homens se mostra não apenas na diversidade das suas tábuas de bens, isto é, no fato de que tornem certos bens como desejáveis e que estejam em desacordo quanto ao valor maior ou menor, quanto à hierarquia dos bens reconhecidos por todos - ela se mostra mais ainda no que consideram que é ter e possuir verdadeiramente um bem”. (NIETZSCHE, Friederich. op. cit., p. 82.).

${ }^{577}$ NIETZSCHE, Friederich. op. cit., p. 19.
} 
indivíduo exibe seus "objetos", que representam o "poder" adquirido na sociedade. Mas ele não pode se livrar da sua condição de mercadoria, representando que ele é passível de ser “objeto" de domínio (propriedade). Cria-se a ilusão de poder para manter a submissão e atribui-se o fracasso individual (ser objeto e dominar qualquer objeto) à falta de empenho. Portanto, o culpado é o próprio indivíduo. Erich Fromm conclui que a auto-estima passa a depender de condições que escapam ao controle do homem:

Se a pessoa acha que seu próprio valor não é constituído primordialmente por suas qualidades humanas, e sim pelo seu sucesso em um mercado competitivo com condições em constante modificação, sua auto-estima provavelmente será pouco sólida e precisará constantemente de ser confirmada pelas outras pessoas. [...] Se as vicissitudes do mercado são os juízes do valor da gente, desaparece o sentimento, a dignidade e brio. ${ }^{578}$

Amartya Sen alerta que "a natureza da economia moderna foi substancialmente empobrecida pelo distanciamento crescente entre economia e ética" ${ }^{579}$. Disso decorre a falta de solidariedade e de alteridade nas relações humanas. A sociedade ocidental moderna impõe o progresso, fixando-se totalmente no mundo exterior. Como foi visto, o homem é reificado e, diante do sentimento de fragmentação e falta de significado, as forças reprimidas muitas vezes acabam por se manifestar de forma patológica: sintomas psicossomáticos, compulsões, depressões e neuroses. ${ }^{580}$

\footnotetext{
${ }^{578}$ FROMM, Erich. Análise do homem, cit., p. 69.

${ }^{579}$ SEN, Amartya. Sobre ética e economia. Trad. Laura Teixeira Motta. São Paulo: Companhia das Letras, 2002. p. 23.

${ }^{580}$ JOHNSON, Robert A. A Chave do Reino Interior. São Paulo: Ed. Mercuryo, 1989. p. 18-19. Erich Fromm alerta para os riscos de uma análise sociológica ou psicológica baseada no racionalismo, por ele denominada "realista": "Os 'realistas' asseveram que o problema da ética é uma relíquia do passado. Dizem que a análise psicológica ou sociológica prova que todos os valores só são relativos a uma dada cultura. Postulam que nosso futuro individual ou social está garantido exclusivamente por nossa eficiência material. Contudo, esses 'realistas' ignoram alguns fatos indiscutíveis. Não vêem que a vacuidade e a desorientação da vida individual, que a falta de produtividade e a conseqüente falta de fé, se prolongadas, provocam distúrbios emocionais e mentais que podem incapacitar o homem até para a consecução de seus objetivos materiais". (Análise do homem. Cit. p. 210). Um dos reflexos desse quadro é o aumento constante do número de trabalhadores afastados das suas atividades por acidentes de trabalho, incluindo nesses os casos de doenças ocupacionais. "Os benefícios previdenciários decorrentes de acidentes de trabalho e de atividades insalubres representaram custo de R\$10,7 bilhões para a Previdência Social, em 2007. Foram R \$ 5,075 bilhões em pagamento de auxílios por doença, por acidente e suplementar, e também com aposentadorias por acidentes e doenças ocupacionais." (AGÊNCIA DE NOTÍCIAS DA PREVIDENCIA SOCIAL. MINISTÉRIO DA PREVIDENCIA SOCIAL. Acidente de trabalho: Gastos da Previdência $\begin{array}{lllllll}\text { chegam } & \text { a } & \mathrm{R} \$ & \text { bi. } & \text { Disponível } & \text { em: }\end{array}$ //www.previdenciasocial.gov.br/AgPREV/agprev_mostraNoticia.asp?Id=29303\&ATVD=1\&DN1=06/02/2 008\&H1=14: $00 \& x B o t a o=0>$. Acesso em: 20 jul. 2008).
} 
E ao trabalhador da atualidade cabe agir como Sísifo, carregando a rocha infinitamente, quando não é compelido a se metamorfosear como Proteus:

Enquanto a utilidade que vigora nos juízos de valor morais for apenas a utilidade do rebanho, enquanto o olhar estiver dirigido apenas à preservação da comunidade, e for tido como imoral precisamente e exclusivamente o que parece perigoso para a subsistência da comunidade: enquanto assim for não pode haver "moral do amor ao próximo". 581

A capacidade de ver o outro estimula a solidariedade e a valorização do trabalho humano, que se convertem em autênticos princípios constituintes de cada indivíduo e da sociedade. Na esfera jurídica, a proposta dos Direitos Humanos é, precipuamente, chamar o homem ao encontro de si mesmo, para estabelecer o guia de suas ações e conjugar os interesses, no intuito de preservar e melhorar as condições de sua própria vida. Goffredo da Silva Telles Júnior, em sua autobiografia A Folha Dobrada, expressa a importância do Direito:

Para mim, o Direito sempre se apresentou como guia para a liberdade e a justiça. (...) Se queremos chegar a um determinado objetivo, o Direito nos indica o caminho. Logo entendi que o que caracteriza o Direito, antes de mais nada, é sua natureza informativa, instrutiva, conselheira, pedagógica. ${ }^{582}$

O que se propõe, enfim, é que o Direito estimule o diálogo entre os discursos a partir do referencial jurídico. Do contrário, princípios como trabalho digno e prevalência dos direitos humanos, expressos no texto constitucional, permanecem como símbolos de uma sociedade negligente com a própria História. Um primeiro passo, portanto, seria "constitucionalizar" a legislação trabalhista, para que a dignidade do trabalhador seja vislumbrada nos moldes da Constituição de 1988. A razão jurídica passa, então, a ser um elemento fundamental não para diminuir a complexidade, mas para contemplá-la e identificar recursos técnicos para fomentar soluções, reconhecendo seus limites e a necessidade de compreender o trabalho humano como reflexo da própria condição humana. Se não se conhece a condição humana, não é possível identificar possíveis soluções para os dilemas do mundo do trabalho. E a condição humana vai além do físico, do material, e só se perfaz no contexto relacional.

\footnotetext{
${ }^{581}$ NIETZSCHE, Friederich. op. cit., p. 87.

${ }^{582}$ TELLES JÚNIOR, Goffredo da Silva. A folha dobrada: lembranças de um estudante. Rio de Janeiro: Nova Fronteira, 1999. p. 70-71.
} 
O sentimento de dor é um dado que não pode ser suprimido da análise das relações de trabalho, pois é parte da condição humana. A questão é que

os pesquisadores médicos ainda não sabem precisamente o que causa a dor, nem entendem totalmente as vias de comunicação entre corpo e mente. (...) Para entendermos a dor e sermos capazes de aliviá-la no processo da cura, devemos considerá-la em seu contexto mais amplo, que inclui as atitudes e expectativas mentais do paciente, seu sistema de crenças, o apoio emocional da família e dos amigos e muitas outras circunstâncias. ${ }^{583}$

Como explica Capra, há de se superar a tendência à negação da dor e à associação imediata da dor a algum distúrbio fisiológico específico, atenuado por meio de analgésicos. ${ }^{584}$ É admitir a fragilidade e as limitações do ser humano, especialmente no processo dinâmico das relações de trabalho subordinado e abandonar a tendência de projetar no trabalhador a imagem do incansável Sísifo ou do flexível Proteus. O projeto de lei n. 7.202/2010, que propõe tratar o assédio moral como modalidade de acidente do trabalho, já aponta para isso.

Enfim, no âmbito das relações de trabalho subordinado da atualidade, cabe a tarefa de identificar a eficiência não apenas em termos financeiros - e sim a eficiência econômica como também psicossocial -, reconhecendo o trabalhador como ser humano e permitindo dimensionar os contornos da sua dignidade conforme os referenciais definidos pela Constituição, no contexto de uma sociedade plural e complexa.

\footnotetext{
${ }^{583}$ CAPRA, Fritjof. O ponto de mutação: a ciência, a sociedade e a cultura emergente, cit., p. 135.
}

${ }^{584}$ Id., loc. cit. 


\section{CONCLUSÃO}

Ainda que inexistente um entendimento pacífico, é bastante difundida a origem etimológica da palavra trabalho, como derivada de tripalium, um instrumento de tortura, ou palum e tripalis, variante de trepalium, cavalete de três paus, usado para sujeitar os cavalos no ato de aplicar a ferradura. Nesse breve estudo, retirou-se o enfoque da origem da palavra "trabalho" para tentar buscar orientações que conduzam ao porquê da aceitação da ideia de trabalho como algo penoso.

O trabalho subordinado, que surge com o sistema moderno de produção, ficou marcado pela sua natureza exploratória e pela execução de tarefas repetitivas, sem criatividade. Contudo, pôde-se perceber que a noção de trabalho passa pela relação entre empregador e empregado, e não necessariamente pela espécie de tarefa executada, desde que respeitada a integridade física do homem.

Quando se afirmou com Karl Polanyi que a civilização do século XIX ruiu, o que se enunciou foi um desafio sobre a possibilidade de superar as contradições do modelo juslaboral brasileiro existente frente aos novos contornos que as relações de trabalho subordinado vêm a assumir, especialmente a partir da evolução dos modos de organização da produção.

O progresso técnico-científico impulsionou as mudanças no mundo do trabalho e segue a introduzir novos formatos de como o trabalho humano pode ser melhor dimensionado e aproveitado. Por isso afirmou-se que um paradigma - a exemplo do tecnocientífico - não é substituído por outro, como se a estrutura e a forma de organização peculiares ao paradigma anterior fossem absolutamente substituídos pelo novo. Observouse que o papel da tecnologia é cada vez mais determinante para as transformações promovidas na sociedade e influenciam diretamente sobre as relações de trabalho subordinado.

Verificou-se que o culto à razão humana persiste sob a roupagem da certeza de que a implementação de recursos tecnológicos é uma realidade inquestionável. A automação é introduzida no meio ambiente do trabalho e novas formas de organização do trabalho são concebidas sob a inspiração dos parâmetros científico-tecnológicos. Ao homem trabalhador cabe conformar-se, ou melhor, adaptar-se. Assim, se a forma de organização ainda se baseia no modo taylorista-fordista, espera-se que o trabalhador se molde à figura 
de Sísifo; do contrário, se a proposta é atribuir ao trabalhador maior responsabilidade pelo resultado da produção, adota-se o modo toyotista e sai de cena o "homem-macaco" - mãode-obra fisicamente saudável e mentalmente condicionada à repetição - e entra o trabalhador polivalente, capaz de se metamorfosear, à semelhança da figura de Proteus.

Reconhece-se que o ser humano trabalhador é avaliado de acordo com as necessidades presentes na dinâmica das relações de trabalho subordinado. O papel do trabalhador subordinado (empregado) apresenta-se como uma "coisa pronta", uma descoberta extraída da observação do contexto sócio-econômico de determinado momento. Dessa forma, a imprescindibilidade de que o empregado realize uma jornada de 12 horas de trabalho por 36 horas de descanso dá-se em razão da natureza da atividade por ele exercida, isto é, justifica-se pela utilidade prática e observável da adoção desse sistema de jornada, afastando o questionamento sobre o impacto psíquico-biológico sobre o empregado.

Motivam-se as decisões no campo das relações de trabalho subordinado sob a óptica da objetividade dos resultados mensuráveis. O trabalho humano subordinado é, nessa perspectiva de análise, um objeto empírico, e não um ato social. Como objeto, o trabalho humano subordinado pode ser submetido ao controle e à organização, introduzidas por técnicas e recursos tecnológicos. A justificativa é maximizar a extração da força laborativa, com base no resultado de uma avaliação que se baliza pela noção de eficiência aferível economicamente. Contudo, na medida em que a racionalidade científica se pauta na análise de propostas e resultados objetivamente calculáveis, afasta-se, em um primeiro momento, a discussão sobre os aspectos psicológicos e sociais sobre a vida do homem empregado. Conclui-se que a importância dos avanços tecnológicos é uma realidade incontestável, mas o problema repousa na possibilidade de legitimação do exercício de um poder praticamente ilimitado, de forma explícita ou implícita, sob o argumento de que é necessário atingir determinados resultados objetivos.

O modelo racional e objetivo influenciou a noção de Direito. O positivismo e a codificação do Direito determinaram uma ordem jurídica fundada nos parâmetros técnicocientíficos e sustentaram, assim, o avanço da ordem econômica capitalista. A noção de certeza e segurança jurídica aproxima o discurso do Direito da noção de cálculo de risco e de organização da realidade pelo uso da razão. No entanto, mais uma vez destacou-se que as criações derivadas da razão humana não podem estar dissociadas do próprio ser humano que as originou. Não se sustenta a ideia de que o positivismo desconsidera a discussão 
axiológica em nome da neutralidade científica, na medida em que a ciência positivista determina uma escala de hierarquia e de relevância. Enfim, não há escolhas, sejam elas absolutamente técnicas ou não, que não se fundamentem em valores.

Na esfera do Direito, a codificação apresentou-se na forma mais eficiente para sistematizar, formalizar, monopolizar e burocratizar, por meio da ação do Estado. O sistema jurídico estruturado na forma de códigos dispensou a discussão dos impactos das normas na sociedade e as mudanças que ocorrem especificamente nas relações de trabalho subordinado. Ele partiu de um modelo simplificado de sociedade, em que o Direito é concebido como um sistema cuja organização é capaz de antever os conflitos sociais e apresentar soluções prontas e acabadas, na forma de normas gerais e abstratas. A base do Direito codificado, nos moldes do positivismo científico, é uma análise empírica dos fatos, sua dissecação em elementos redutíveis às normas e a aplicação das mesmas ao caso concreto. Sob essa vertente, não haveria conflito social para que o Direito não tivesse resposta objetivamente identificável. Daí vem a máxima a ser seguida pelos magistrados: “Dá-me os fatos que eu darei o Direito".

Conclui-se que o formalismo, a generalidade e a abstração das normas jurídicas foram importantes politicamente, para garantia da estabilidade social e promoção da segurança jurídica. Porém, do ponto de vista econômico, a igualdade formal defendida pela norma jurídica alicerçou uma estrutura organizacional das relações de trabalho eminentemente opressora para o trabalhador.

O homem é plural, tal qual a sociedade, e a pluralidade afasta a ilusória ausência de conflitos. Reconhecer os conflitos é essencial para encontrar meios para melhor compreendê-los. Os conflitos humanos partem da inexistência de uniformidade de interesses e da presença de oposição de forças. Na relação de trabalho subordinado, a tentativa de ocultar o abuso de poder foi sustentada pela própria legislação, sob a roupagem da natureza civilista contratual do trabalho, e pela simbologia subjacente na relação entre "patrão e operário". Se a liberdade e a igualdade, como postulados da ordem jurídica do Estado de Direito, representaram um progresso em termos políticos, o resultado da adoção da base jurídica civilista para disciplinar as relações de trabalho conferiu hegemonia ao poder do capital. Tal cenário conduziu à submissão do trabalhador e à exposição a condições aviltantes em nome da produção e do lucro, desde o período da transição do modo de produção artesanal para o manufatureiro até o alvorecer do processo de reconhecimento dos direitos de proteção do trabalhador. 
Os direitos dos trabalhadores compõem os direitos humanos de segunda dimensão, ou seja, são direitos sociais, que visam à promoção da igualdade e, dessa forma, ao bemestar social. Conclui-se que a afirmação dos direitos humanos corresponde à constatação de que a sociedade é complexa, não se limitando à visão de mundo mecanicista, e ela é, portanto, não-linear. A teoria dos direitos humanos permite admitir o cenário social formado pela pluralidade de interesses e de parâmetros para a compreensão da realidade.

Na medida em que a complexidade deixa de ser reduzida, por meio do fracionamento do objeto a ser estudado, exige-se do sujeito-observador da realidade a árdua tarefa de vincular a infinidade de conflitos interrelacionados. Para os fins deste estudo, focaram-se as relações de trabalho subordinado. Por isso, uma questão aparentemente de cunho exclusivamente técnico, como a exposição do trabalhador a riscos à saúde e à segurança no meio ambiente do trabalho, ultrapassa a seara objetiva e suscita a discussão sobre os contornos acerca da concepção da dignidade do trabalhador.

A dignidade do trabalhador extrapola o referencial do indivíduo e contempla o ideal de coletividade. Quando se almeja garantir um ambiente de trabalho seguro e saudável, não se dirige o olhar apenas para determinado(s) trabalhador(es), mas para a coletividade como um todo. O que se preza é a existência humana digna e ela é extensível a todos os trabalhadores envolvidos em determinada relação de trabalho subordinado.

Essa transição do individual para o coletivo exige alteridade. O distanciamento da realidade social não é admitido no contexto da teoria de direitos humanos. A abstração e a generalização normativa enfrentam o desafio de atender à pluralidade de discursos, característica da sociedade pós(hiper)-moderna. Conclui-se, então, que a formalização imprimida pelo positivismo jurídico não garante imunidade ao sistema jurídico, o qual convive em um ambiente de colisão entre diferentes racionalidades.

O novo Direito dos conflitos, como proposto por Gunther Teubner, ocupa-se não mais em resolver conflitos internos ao próprio sistema jurídico, mas assume a função de decidir entre racionalidades conflitantes derivadas de diferentes discursos. Supera-se a preocupação primordial com os velhos conflitos interpessoais. Ao invés de discutir limites de autonomia individual, por exclusivo, o novo Direito dos conflitos volta-se para a dinâmica dos discursos. $\mathrm{O}$ argumento legal transita pelas racionalidades particulares e diversas, institucionalizadas jurídicas, e volta para essas bases. A resolução permanente do conflito não é perseguida, pois não é possível conciliar peremptoriamente as diferenças na 
sociedade. O resultado expressa-se na garantia da efetividade dos direitos fundamentais, ou seja, dos direitos humanos consagrados constitucionalmente.

Na medida em que o conteúdo normativo perpassa pelas diversas racionalidades, realiza-se um processo de tradução. No caso das relações de trabalho subordinado, o processo de tradução das referências econômicas, políticas e sociais depende da observância do formato "constitucional", a fim de se obter resultados adequados e aceitáveis. Por exemplo, o princípio da norma mais favorável, sob o formato constitucional, traduz-se como o princípio da aplicação da norma que promova a dignidade do trabalhador.

Debruçar-se sobre a racionalidade presente nas ações dos principais sujeitos da relação de trabalho subordinado - empregado e empregador - auxilia na compreensão da dinâmica do poder e da sua regulação. Propõe-se, então, suscitar a discussão de como o sistema juslaboral brasileiro emprega mecanismos de contenção dos danos e violações a direitos decorrentes do exercício do poder e garante a dignidade nas relações de trabalho subordinado.

Sob a óptica liberal capitalista, a natureza humana conduz o indivíduo às melhores decisões. Logo, desnecessária a existência de intervenção sobre as relações, especialmente a estatal. O Estado, para os liberais, teria sua importância na manutenção da ordem pública e da segurança social, indispensáveis para o exercício dos direitos individuais, dentre eles o de propriedade.

A acumulação da propriedade de bens, como fundamento decantado pelo capitalismo, modela a vida social e individual, de sorte que, na esfera do trabalho humano, a regra do trabalho como fonte de sobrevivência é suplantada pela regra da acumulação. A necessidade humana cede espaço à lógica do sistema econômico. É certo que quem não pode acumular bens acaba por vender o seu único produto - força de trabalho - para garantir exatamente a sua sobrevivência. Ao contrário do que se pode imaginar, a produção realizada, isto é, o fruto do trabalho em si não se destina à sobrevivência humana, mas à acumulação do capital.

É essa a diferença entre a racionalidade econômica, que permeia as ações do empregador, e a racionalidade presente nas ações do empregado. Admitida a ficção de que o trabalho é "produto", "fator de produção" negociado via contrato - pois a força de trabalho consistiria na propriedade do trabalhador -, o capital encontra-se autorizado a 
introduzir uma estrutura burocrática institucionalizada, voltada à maximização dos seus interesses. O ideal do homo oeconomicus viabiliza a exploração das potencialidades humanas com base em um enfoque objetivo. O homem, como ser biológico, tem capacidade de produzir e a maior produtividade depende de métodos de gestão adequados e eficientes. O trabalhador, contratado para realizar uma tarefa produtiva, é mais um elemento da organização do trabalho. A função do trabalhador restringe a empreender seus esforços para a maximização dos interesses econômicos, nos termos do contrato: ampliação do capital (interesse do empregador) em face da garantia de pagamento da contraprestação pelo trabalho (interesse do trabalhador).

Ao caráter objetivo do acima descrito soma-se a racionalidade decorrente do desenvolvimento das ciências humanas, nos finais do século XIX e, em princípios do século XX. O despertar da análise psicológica apresenta a noção da centralidade do trabalho no processo de construção psicológica da identidade. Para além da objetividade da exploração do potencial físico do trabalhador, o trabalho é vislumbrado como referência central na construção da individualidade. Essa afirmação chama a atenção para os danos e riscos eventuais e/ou patentes que o trabalho mal organizado e gerenciado provocam ao indíviduo-trabalhador. Ao extrapolar os limites da análise técnico-científica, mais do que uma análise de riscos físicos, químicos e biológicos produzidos pelo meio ambiente do trabalho, atenta-se para os riscos oriundos da dinâmica das relações humanas decorrentes do contrato de trabalho subordinado.

Nesse contexto, formação profissional e qualificação fazem parte de um modelo normativo estável, inadaptado à dinâmica da pós(hiper)-modernidade. Exige-se do trabalhador a polivalência, mais que a obediência às regras de uma organização de trabalho estática, com tarefas pré-definidas, características dos modelos taylorista-fordistas. O discurso da empregabilidade, por exemplo, retrata essa nova "realidade pessoal". A falta de emprego ou de possibilidade de crescer na carreira não são decorrências de um modelo de organização de trabalho que atomiza e desarticula o trabalhador, mas uma carência de requisitos imprescindíveis para se destacar dos demais. Impõe-se uma lógica darwinista no âmbito das relações de trabalho subordinado, o que, inevitavelmente, gera mal-estar para o trabalhador.

Em princípio, a figura do patrão veio manter na obscuridade o aspecto sombrio do mundo subterrâneo em que o trabalhador se envereda. A noção de patrão remeteu ao ideal de proteção, um pai a garantir a subsistência de seus dependentes. E o mito se reinventa, 
pois atualmente o patrão não precisa estar personificado; ele (o "deus") se metamorfoseia na "flexibilização dos direitos trabalhistas", na "volatilidade do capital", na "gerência participativa", na "empregabilidade". O "patrão despersonificado" que não se manifesta em atitudes explícitas de abusos de poder.

A questão é que esse discurso de poder é aceito e suas consequências são conhecidas: a) transfere a culpa pelo fracasso à incapacidade de adaptação ao modelo (molde/uniforme) imposto; b) a subjetividade é valorizada sob a forma de uma sociedade competitiva; e c) o maior risco é imposição de um paradigma pautado na ausência de alteridade.

O poder de violência simbólica presente nas relações de trabalho subordinado obstaculiza a alteridade, a capacidade de ver o outro como indivíduo criativo e apto a realizar o pleno desenvolvimento de sua potencialidade. A conversão do homem em mera peça de um mecanismo com funcionamento automático (isto é, que independe da ação humana) exclui, enfim, a condição humana e o trabalho limita-se a ser uma sucessão de atividades infindáveis, muitas vezes sem um objetivo identificável, ou seja, um castigo. E, assim como Sísifo, o trabalhador submete-se à vontade de "deuses". A flexibilização das instituições e das normas, por sua vez, retomou o ideal de indivíduo abstrato e racional, criando a ilusão de que o trabalhador pode ser Sísifo ou Proteus, de acordo com a adaptação exigida.

Se a sociedade se pauta na dignidade humana, tornar-se um indivíduo depende do reconhecimento das suas potencialidades. O trabalhador somente pode reconhecer suas potencialidades como homem na medida em que haja garantia do respeito à sua integridade biopsicológica na esfera das relações de emprego. Daí extrai-se a relevância da função do Direito do Trabalho, como expressão dos direitos fundamentais sociais: evocar e contribuir para o processo de integração do homem à sua essência.

A dificuldade está na complexidade e na pluralidade sociais. Como estar preparado para uma realidade cujos contornos não estão objetivamente dimensionados? Questiona-se, assim, como o Direito do Trabalho mantém sua integridade sistêmica, diante da complexidade semântica inerente à ideia de trabalho e a sua relação na construção do indivíduo.

As práticas organizacionais operam com discursos que mascaram uma estrutura de dominação e ocultam o conflito natural presente nas relações de trabalho. A ausência da 
figura do empregador-"patrão" e a presença de uma "força irresistível e de forma indefinida" denotam o apogeu da sofisticação do funcionamento dos mecanismos de burocratização do poder. A carreira proteana, por exemplo, traduz a nova visão do empregador em relação à propriedade do trabalho: o trabalhador pode ser "dono de si mesmo". Assim, ao trabalhador cabe definir o seu "destino", individualmente.

A forma de organizar o trabalho pode determinar o esfacelamento da consciência do trabalhador sobre o seu papel social e do grupo ao qual pertence, de sorte que instrumentos/mecanismos de defesa - como a greve - perdem espaço na estrutura de poder. $\mathrm{O}$ individualismo determina o rompimento com a solidariedade e o companheirismo que integra o trabalhador a um grupo. A perda da solidariedade e do pertencimento a um grupo limitam o exercício da liberdade dos trabalhadores, dado que a forma de luta e participação dependia da presença da consciência coletiva.

Dessa forma, torna-se fundamental indagar sobre os obstáculos ao exercício da liberdade, muito mais do que buscar identificar quem detém o poder. Na sociedade complexa e plural, o modelo de redução da complexidade avança para o modelo de compreensão da dinâmica da complexidade, em que o poder não é mais necessariamente concentrado em indivíduos, mas perpassa a sociedade. As novas formas de gestão reproduzem esse cenário de mudança do exercício do poder nas relações de trabalho subordinado.

As questões relativas ao mundo do trabalho dependem do enfoque coletivo. O que se observa é que as relações de trabalho e seus conceitos são construídos a partir das relações estabelecidas em sociedade. Mas, em um quadro complexo e marcado por conflito de interesses, a concepção de trabalho é modelada de acordo com o discurso adotado: como exploração de um fator de produção ou instrumento de garantia de sobrevivência.

O sistema jurídico, a fim de conferir mecanismos de promoção da segurança e paz sociais, dispõe de instrumentos de verificação do cumprimento das normas pelos particulares. Um deles é a fiscalização do trabalho. Para corrigir eventuais desajustes ou desequilíbrios comprometedores da promoção dos direitos fundamentais do trabalhador, o Estado vale-se até mesmo do monopólio da força - imposição de sanção - como recurso para alcançar o respeito ao trabalho, entendido constitucionalmente como valor social. Às relações de trabalho subordinado confere-se, então, o status de questão de ordem pública, o que torna legítima a imposição de limites ao exercício da autonomia pelos indivíduos. 
A ideia de ordem pública remete a um sistema de normas voltado à garantia da segurança e da vida em sociedade. No sistema jurídico brasileiro, a ordem pública traduzse na natural indissolubilidade entre o trabalho e o homem. Em face disso, a Constituição Federal de 1988 (CF/88), em seu artigo $7^{\circ}$, inciso XXII, dispõe como direito fundamental a "redução dos riscos inerentes ao trabalho, por meio de normas de saúde, higiene e segurança”. O enfoque do constituinte está na garantia de um meio ambiente de trabalho saudável e seguro ao trabalhador. Embora atinja o trabalhador individualmente considerado, o texto constitucional busca alcançar a coletividade de trabalhadores: o meio ambiente do trabalho.

Cabe, destarte, definir quais seriam os riscos e suas consequências. Dado o paradigma técnico-científico, preserva-se o trabalhador das influências danosas de agentes químicos, físicos e/ou biológicos, a partir da identificação das propriedades e da quantidade máxima de contato que o ser humano pode tolerar. Com base nisso, indagar-seia como explicar o alto índice de acidentes de trabalho.

A compreensão da dinâmica das relações de trabalho, especificamente quanto à prevenção de acidentes, a partir da racionalidade econômica, permite descrever a conduta dos agentes racionais, conforme citado no capítulo III da tese:

a) os trabalhadores demandarão remuneração adicional, ou um "prêmio adicional", para compensá-los dos riscos à saúde e à segurança a que são expostos no ambiente de trabalho;

b) os empregadores adotarão medidas de redução de riscos até o ponto de ser menos custoso pagar aos trabalhadores o adicional sobre a remuneração do que investir na implementação de prevenção contra riscos à saúde e à segurança do trabalhador.

Como estimular condutas de proteção à vida e à saúde do trabalhador, apresentados esses referenciais de ação? Inicialmente, em face do paradigma econômico capitalista, o trabalho subordinado foi e é indispensável para a dinâmica da sociedade, não obstante a discussão sobre a necessidade do modelo de trabalho para a manutenção do sistema econômico. Conclui-se que o modelo de relação de trabalho subordinado concorre com outras formas de relações de trabalho, em princípio, mais adaptadas ao contexto econômico, porém a "classe-que-vive-do-trabalho" não desapareceu e não tende a desaparecer. 
São várias as formas de desvirtuamento do modelo de relações de trabalho subordinado para outras modalidades, com o propósito de afastar as implicações legais do contrato de trabalho, a exemplo da "pejotização" ou "cooperativas fraudulentas", além dos chamados modelos de gestão de qualidade (como o International Organization for Standartization - ISO). E o comprometimento à vida do trabalhador, nesse contexto, alcança a higidez psíquico-biológica. Como consequência, a tarifação da saúde do trabalhador, prevista no ordenamento jurídico brasileiro quando há exposição a agentes físicos, químicos e biológicos, não é suficiente para promover a proteção da vida e da saúde. A conclusão é de que não são apenas os agentes objetiva e metricamente verificáveis os causadores de danos à saúde e à segurança ao trabalhador. Esse é o desafio que exige percuciência do observador-sujeito da realidade investigada.

Questionar as limitações do modelo juslaboral e sua capacidade para atender à demanda da sociedade plural (múltiplos interesses) e complexa (processo dinâmico com vários sistemas) é possível a partir do contato com essa realidade. $\mathrm{O}(\mathrm{A})$ Auditor(a)-Fiscal do Trabalho, no exercício do seu poder de polícia, foca sua atividade não somente na verificação do cumprimento fiel da legislação vigente, mas também busca manter a ordem pública.

Dessa maneira, o(a) Auditor(a)-Fiscal do Trabalho, ao ingressar no estabelecimento, assume não apenas sua condição de observador de uma realidade, mas também passa a ser sujeito e a participar da dinâmica da relação de trabalho subordinado. É essa função que permite identificar os matizes dos conflitos inerentes à relação de trabalho subordinado, muitas vezes latentes ou pouco perceptíveis no cotidiano da prestação de serviço, como é o exemplo do discurso atual das gestões participativas.

O desafio da Auditoria-Fiscal do Trabalho é também participar da formatação dos contornos do conceito de dignidade do trabalhador. Para tanto, o(a) Auditor(a)-Fiscal do Trabalho lida com a dificuldade de avaliar o alcance e os limites dos conceitos indeterminados. E, ausente uma descrição clara do que seria "segurança", "saúde", ou mesmo "dignidade", haveria um consenso mínimo em torno desses conceitos?

A atividade da fiscalização do trabalho vai além dos limites de uma concepção juspositivista-racional e abrange o conteúdo definido por dignidade do trabalhador. Como a ideia de direitos fundamentais encontra justificativa na necessidade de limitação de poder, conclui-se que a Auditoria-Fiscal do Trabalho, ao intervir nas relações de trabalho subordinado, amplia para os particulares o alcance da eficácia dos direitos fundamentais. 
A eficiência da atividade fiscalizatória depende da compreensão que o(a) Auditor(a)-Fiscal do Trabalho tem acerca dos discursos presentes nas relações de trabalho subordinado. $\mathrm{O}$ argumento de falta de recursos para implementar determinadas medidas protetivas, por exemplo, pode ser avaliado, ao longo da fiscalização, como efetivamente uma limitação fática ou um artifício ideológico. O(A) Auditor(a)-Fiscal ingressa como partícipe/interlocutor na estrutura de poder da relação de trabalho subordinado. No contexto de complexidade, o observador é simultaneamente sujeito. E a importância do pensamento sistêmico está no fato de ser um recurso teórico que permite vislumbrar o papel do(a) Auditor(a)-Fiscal dessa forma.

A afirmação histórica dos direitos fundamentais apontou para as distorções dos discursos que tendiam a mascarar a predominância da racionalidade econômica. Mas o risco do surgimento de novas lógicas discursivas não foi totalmente afastado com a introdução dos direitos fundamentais no ordenamento jurídico. Exemplo disso foi o fenômeno conhecido como flexibilização. Argumentou-se que a legislação trabalhista, de caráter essencialmente protetiva, não poderia ser admitida em momentos de transformações econômicas. Defenderam-se as modificações na organização e na disciplina do trabalho, que aproximaram o trabalhador à figura do deus Proteus.

A fragilidade do arcabouço jurídico estatal - fragmentado e assimétrico - acaba por admitir a existência de decisões que mascaram a prevalência de um discurso em detrimento do outro. Nas decisões que envolvem as relações de trabalho subordinado, corre-se o risco de o sistema juslaboral perder as referências internas e de distinção com o ambiente. A flexibilização de direitos fundamentais de proteção ao trabalhador é o exemplo da introdução de elementos de outros códigos, direcionando o discurso à viabilidade econômica ou à manutenção do sistema legal de proteção ao trabalhador, ao invés de focar na construção dos contornos da dignidade do trabalhador.

A “constitucionalização" das relações de trabalho subordinado depende da discussão sobre a construção do conceito de dignidade na sociedade pós(hiper)-moderna. Mas existe um conceito possível de dignidade, tendo em vista que a construção do sentido depende das referências adotadas pelo observador-sujeito?

Embora o sentido do trabalho tenha passado por transformações, a estrutura econômica manteve-se e a realidade do empregado sofreu mudanças de forma, mas não de conteúdo (sobrevive a "classe-que-vive-do-trabalho"). Paulatinamente o Direito passou e 
passa a incorporar novos elementos, os quais foram traduzidos em direitos fundamentais, cujo fundamento no sistema jurídico brasileiro é a dignidade da pessoa humana.

O cenário histórico brasileiro aumenta o desafio, pois, após a abolição da escravatura, o discurso liberal do Brasil da República Velha mantém acomodado o trabalho livre na estrutura patrimonialista da economia brasileira. Prevaleceram os interesses econômicos e, menos de cinquenta anos depois, a Consolidação das Leis do Trabalho surge como resultado de uma escolha da qual não participaram os seus principais destinatários: os trabalhadores. Embora formalmente relevante do ponto de vista de proteção ao trabalhador, uma legislação de cunho social elaborada sem a influência da sociedade caracteriza o regime autoritário que a instituiu.

Conclui-se, assim, pelo inevitável descompasso entre as bases da CLT e a Constituição da República de 1988. A proposta apresentada, com vistas a “constitucionalizar" o texto consolidado, parte inicialmente da concepção de trabalho como ação. A ação humana somente é possível onde há liberdade. Assim, para haver trabalho digno, não é admissível qualquer hipótese de constrangimento ou limitação à ação humana livre.

A Consolidação das Leis do Trabalho deve ser interpretada, portanto, sob o referencial constitucional. Além disso, as alterações normativas também não podem se afastar desse referencial. Se o legislador, seja ele autônomo ou heterônomo, identificar o trabalho como um fator de produção, as normas não se fundamentarão sobre valores essenciais ao ser humano. Ao elaborar regras sobre a compra e venda de um imóvel, por exemplo, o legislador ocupa-se com elementos objetivos. Contudo, ao tratar da penhorabilidade dos bens, o mesmo imóvel, se for a residência de uma família, será diferentemente considerado pelo legislador, o qual passa a se ocupar com o valor humano que subjaz à questão. Nessa hipótese, a garantia de uma moradia - segurança e condições dignas de vida humana - prevalecerá sobre a relação de natureza material.

Observou-se, então, que a CLT, na esteira do que propõe Teubner, na nova teoria do Direito (Direito dos conflitos), teria de refletir o jogo entre as referências praticadas no cenário das relações de trabalho subordinado, em que se destacam os pontos de observação do empregador e do empregado, e traduzi-las em uma forma 'constitucional', especificamente em termos de dignidade do trabalhador. 
No caso dos riscos à saúde, concluiu-se que se demanda do sistema jurídico a proposição de mecanismos de estímulo de condutas de promoção da dignidade humana, a exemplo da ampliação conceitual dos agentes danosos à saúde e à vida do trabalhador. Nessa esteira, citou-se a apresentação do projeto de lei n. 7.202/2010, de 28 de abril de 2010, que trata do assédio moral como modalidade de acidente do trabalho.

A análise desses problemas direcionou-se para a organização do trabalho e para os impactos causados no meio ambiente do trabalho e nos subsistemas (empregado, economia, família, ecologia etc.) envolvidos. A dignidade no trabalho é construída a partir de um processo relacional dinâmico. Portanto, a abordagem sistêmica é indispensável para identificar a organização dos elementos dentro da estrutura da relação de trabalho subordinado.

Foi possível verificar que as medidas de compensação, tais como adicionais sobre a remuneração, não são eficientes por si só, ainda que as regras sobre responsabilidade civil fossem bem elaboradas. As medidas de compensação remuneratórias isoladamente não estimulam condutas que eliminam ou neutralizam os riscos à saúde ou à vida dos trabalhadores.

Identificou-se a inconsistência e a falta de um modelo elaborado com eficiência, cuja consequência são falhas na comunicação, na informação, gerando no aumento do custo de transação, além do pouco incentivo para estimular condutas conforme o devido padrão de cuidado (minimização de danos e, portanto, mais custos).

Pensar sobre o modelo de trabalho existente ou possível é previamente discutir as bases em que a norma jurídica trabalhista incidirá. Essa etapa é de relevada importância, dado o estímulo causado sobre as ações humanas a partir da edição de uma norma, a qual não pode ser pensada alheia à realidade social complexa. Afinal, a norma jurídica não é fruto dos gênios do Olimpo.

A prática da jornada de 12X36 e a impossibilidade de acumulação dos adicionais de insalubridade e de periculosidade foram debatidos nesse estudo, com o propósito de demonstrar que o código lícito/ilícito extraído do conteúdo da CLT não é mais suficiente, dado o anacronismo do texto consolidado frente às mudanças no mundo do trabalho. Ademais, concluiu-se que a máquina juslaboral não foi bem elaborada tendo em vista a $\mathrm{CF} / 88$.

O recurso ao Judiciário é fundamental para reparação dos danos pessoalmente suportados, mas deixa a descoberto o impacto dos danos à sociedade. Um acidente do trabalho gera problemas suportados não somente pelo empregador e pelo empregado, pois 
pode implicar a necessidade de reabilitação do trabalhador tanto física quanto psicologicamente ou mesmo a sua incapacidade laboral, com gastos suportados pela Previdência Social.

Inferiu-se do estudo que a noção de dignidade é resultante de um processo dinâmico das relações humanas interligadas. É circular e constante e a construção de sentido deve amparar-se pela ideia de ordem pública, pressuposta como fundamento da sociedade civil. Se, com base no referencial do empregador, o sistema econômico avalia o conceito de trabalho com fundamento na redução dos custos e a busca do máximo bemestar individual, analisou-se que nem sempre essa racionalidade resulta em bons resultados para a coletividade como um todo. Tal constatação serve de fundamento para o afastamento da prevalência da racionalidade econômico-financeira.

Esse trabalho propôs-se a observar os contornos dos discursos que envolvem esses atores presentes na relação de trabalho subordinado, para destacar que a noção sobre a dignidade humana não é um dado absoluto e observável à distância, mas é resultado de um processo em permanente movimento. Por essa razão, os conceitos são derivações de uma dinâmica em que os observadores não buscam extrair a verdade do objeto - um conceito $a$ priori de dignidade -, e sim, a partir da observação, participam e passam a integrar a definição do objeto que visam conhecer.

O presente estudo permitiu constatar que a noção de relações sociais extrapola a esfera do indivíduo-indivíduo e alcança um processo dinâmico entre indivíduo-ambienteindivíduo. Disso decorre a conclusão de que, para apreciar a realidade, se exige que a liberdade esteja cada vez mais imbricada com a noção de igualdade. O indivíduo empregado e empregador - segue capaz de influenciar as transformações do meio em que vive e deixa de ser apenas elemento de um sistema (econômico) para ser sujeito que participa da construção do sentido do trabalho digno.

Conclui-se, então, que o Direito não impõe ruptura, não pacifica conflitos, tampouco se arvora na condição de solucioná-los, mas traduz a pluralidade de interesses com base em um plano de referência desenvolvido pela sociedade, e estimula a compreensão do trabalho como promotor do processo de individualização humana. E esse passa a ser o ponto de partida para a busca, não mais de um consenso sobre a dignidade, mas da construção complexa e plural da dignidade, no contexto de uma ordem constitucional democrática e de reconhecimento dos direitos fundamentais do trabalhador. 


\section{REFERÊNCIAS BIBLIOGRÁFICAS}

AGÊNCIA DE NOTÍCIAS DA PREVIDENCIA SOCIAL. MINISTÉRIO DA PREVIDENCIA SOCIAL. Acidente de trabalho: Gastos da Previdência chegam a R\$ 10,7 bi. Disponível em: <http://www.previdenciasocial.gov.br/AgPREV/agprev_mostraNoticia.asp?Id=29303\&AT $\mathrm{VD}=1 \& \mathrm{DN} 1=06 / 02 / 2008 \& \mathrm{H} 1=14: 00 \& x B o t a 0=0>$. Acesso em: 20 jul. 2008.

ALBRACHT, G. et al. Integrated labour inspection: training system (ILITS). Geneva: International Labour Office, 2006.

ALMEIDA, António José. Empregabilidade, contextos de trabalho e funcionamento do mercado de trabalho em Portugal. Sísifo: revista de Ciências da Educação, Lisboa, n. 2, jan./abr.2007. Disponível em: <http://sisifo.fpce.ul.pt>. Acesso em: 12. out. 2007.

ALMEIDA, Ildeberto Muniz de. Abordagem sistêmica de acidentes e sistemas de gestão de saúde e segurança do trabalho. INTERFACEHS: revista de gestão integrada em saúde do trabalho e meio ambiente, São Paulo, v. 1, n. 2, dez. 2006. Disponível em: $<$ http://www.interfacehs.sp.senac.br/br/artigos.asp?ed=2\&cod_artigo=32. Acesso em: 20 ago. 2010.

Construindo a culpa e evitando a prevenção: caminhos da investigação de acidentes do trabalho em empresas de município de porte médio. Tese (Doutorado) Departamento de Saúde Ambiental da Faculdade de Saúde Pública, Universidade de São Paulo, São Paulo, 2001.

ANTUNES, Ricardo. Dimensões da precarização estrutural do trabalho. In: DRUCK, Graça; FRANCO, Tânia. A perda da razão social do trabalho: terceirização e precarização. São Paulo: Boitempo, 2007.

Os sentidos do trabalho: ensaio sobre a afirmação e a negação do trabalho. 6. ed. São Paulo: Boitempo Editorial, 2002.

ARAUJO, Eneida Melo Correia de. As relações de trabalho: uma perspectiva democrática. São Paulo: LTr, 2003.

ARENDT, Hannah. A condição humana. Trad. Roberto Raposo. 10. ed. Rio de Janeiro: Forense Universitária, 2001.

ARISTÓTELES. Ética a Nicômaco. Trad. Pietro Nassetti. São Paulo: Martin Claret, 2002. 
AUGER, Jean-Baptiste Amand. Les lois de la nature e les lois sociales. Lyon: P.M. Perrelon, 1883.

AULARD, François-Alphonse. Le culte de la raison et le culte de l'être suprême: (17931794): essai historique. Paris: Fèlix Alcan Éditeur, 1892.

BARROS, Alice Monteiro. Curso de direito do trabalho. 3. ed. São Paulo: LTr, 2007.

BAUMAN, Zygmunt. Modernidade líquida. Trad. Plínio Dentzien. Rio de Janeiro: Jorge Zahar, 2001.

BECK, Ulrich. Liberdade ou capitalismo: Ulrich Beck conversa com Johannes Willms. Trad. Luiz Antônio Oliveira de Araújo. São Paulo: Ed. UNESP, 2003.

BENDASSOLLI, Pedro Fernando. O ethos do trabalho: sobre a insegurança ontológica na experiência atual com o trabalho. 2006. Tese (Doutorado em Psicologia Social) - Instituto de Psicologia, Universidade de São Paulo, São Paulo, 2006.

BENEVIDES, Maria Victoria de Mesquita. A cidadania ativa: referendo, plebiscito e iniciativa popular. 3. ed. São Paulo: Ática, 2002.

BERCOVICI, Gilberto; MASSONETTO, Luís Fernando. Breve história da incorporação dos direitos sociais nas constituições democráticas brasileiras. Revista do Departamento de Direito Trabalho e Seguridade Social da Faculdade de Direito da Universidade de São Paulo, São Paulo, v. 2, n. 3, jan/jul. 2007.

BERMAN, Marshall. Tudo o que é sólido se desmancha no ar. Trad. Carlos Felipe Moisés e Ana Maria L. Ioriatti. São Paulo: Companhia das Letras, 2007.

BÍBLIA (N.T.). Evangelho de São Mateus. Trad. Pe. Matos Soares. 11. ed. São Paulo: Edições Paulinas, 1982.

BIGNAMI, Renato. A inspeção do trabalho no Brasil: procedimentos especiais para a ação fiscal. São Paulo: LTr, 2007.

BITTAR, Eduardo; ALMEIDA, Guilherme Assis de. Curso de filosofia do direito. 4. ed. São Paulo: Ed. Atlas, 2005.

BLANPAIN, Roger. O futuro do acordo coletivo. In: ANAIS DO SEMINÁRIO INTERNACIONAL - RELAÇÕES DE TRABALHO - ASPECTOS JURÍDICOS, SOCIAIS E ECONÔMICOS, Brasília: Edição da Secretaria Executiva do Ministério do Trabalho, 1998. 
BOBBIO, Norberto. Eguaglianza e libertà. Torino: Giulio Einaudi Editore, 1995. A era dos direitos. Rio de Janeiro: Campus, 1992. O positivismo jurídico: lições de filosofia do direito. Trad. Márcio Pugliesi, Edson Bini e Carlos E. Rodrigues. São Paulo: Ícone, 1995.

; BOVERO, Michelangelo. Sociedade e Estado na filosofia política moderna. Trad. Carlos Nelson Coutinho. 3. ed. São Paulo: Brasiliense, 1991. et al. Dicionário de política. 7. ed. Trad. Carmen C. Varriale et al. Brasília: Editora Universidade de Brasília, 1995. v. 2.

BOLETIM Sirena: análise de acidentes de trabalho, n. 1, jan./ago. 2010. Disponível: $<$ http://www.moodle.fmb.unesp.br/file.php?file=\%2F52\%2FNoticias\%2FNoticias_2010\% 2Fboletim_jan_ago_2010.pdf>. Acesso em: 20 set. 2010.

BONAVIDES, Paulo. Curso de direito constitucional. 13. ed. São Paulo: Malheiros Ed., 2003.

BORNHEIM, Gerd A. (Org.). Os filósofos pré-socráticos. 12. ed. São Paulo: Cultrix, 2003.

BOURDIEU, Pierre. O poder simbólico. Trad. Fernando Tomaz. 11. ed. Rio de Janeiro: Bertrand Brant, 2007.

BRASIL. Constituição da República dos Estados Unidos do Brasil, de 24 de fevereiro de 1891 com de 1926. Disponível em: $<$ http://www.senado.gov.br/legislacao/BasesHist/asp/detalheDocumento.asp? codBase $=2 \&$ codDocumento $=873 \&$ sgBase $=$ CONS \&q $=$ CONSTITUIÇÃO+DA+REPÚBLICA+DOS+E STADOS+UNIDOS+DO+BRASIL>. Acesso em: 06 ago. 2010.

Constituição da República Federativa do Brasil de 1988. Disponível em: $<$ http://www.planalto.gov.br/ccivil_03/constituicao/constitui\%C3\%A7ao.htm>. Acesso em: 17 ago. 2010.

Constituição da República Federativa do Brasil: promulgada em 5 de outubro de 1988. Contém as emendas constitucionais posteriores. Brasília, DF: Senado, 1988.

- Decreto Legislativo n. 24, de 29 de maio de 1956. Disponível em: $<$ http://www6.senado.gov.br/legislacao/ListaPublicacoes.action?id=110983>. Acesso em: 05 ago. 2010. 
BRASIL. Decreto n. 1.313, de 17 de janeiro de 1891. Disponível em: <http://www6.senado.gov.br/legislacao/ListaPublicacoes.action?id=64469>. Acesso em: 06 ago. 2010.

Lei n. 10.224, de 15 de maio de 2001. Altera o Decreto-Lei no 2.848, de 7 de dezembro de 1940 - Código Penal, para dispor sobre o crime de assédio sexual e dá outras providências. Disponível em: <http://www.planalto.gov.br/ccivil/LEIS/LEIS_2001/L10224.htm>. Acesso em: 20 nov. 2010.

- MINISTÉRIO DO PLANEJAMENTO, ORÇAMENTO E GESTÃO. INSTITUTO BRASILEIRO DE GEOGRAFIA E ESTATÍSTICA - IBGE. Estatísticas do século $X X$. Rio de Janeiro. Disponível em: $<$ http://www.ibge.gov.br/seculoxx/seculoxx.pdf>. Acesso em: 23 nov. 2010.

MINISTÉRIO DA PREVIDÊNCIA SOCIAL. Informações Estatísticas Relativas à Segurança $e$ Saúde Ocupacional. Disponível em: $<$ http://www.previdencia.gov.br/conteudoDinamico.php?id=500>. Acesso em: 02 jan. 2009; 22 nov. 2010.

MINISTÉRIO DO TRABALHO E EMPREGO. Convenção da OIT. Brasília: MTE-SIT, 2002.

MINISTÉRIO DO TRABALHO E EMPREGO. Política Nacional de Segurança e Saúde do Trabalhador: Proposta para Consulta Pública - versão pronta após sugestões 29.12.2004. Brasília, 2004. Disponível: em: <http://www.mte.gov.br/seg_sau/proposta_consultapublica.pdf>. Acesso em: 20 dez. 2008. BRIZON, Pierre. Histoire du travail et des travailleurs. 4.ed.. Bruxelles: Édition de L'Églantine, 1926.

BUENO, Francisco da Silveira. Grande dicionário etimológico-prosódico da língua portuguesa. São Paulo: Saraiva, 1968.

CAENEGEM, R. C. van. Uma introdução histórica ao direito privado. Trad. Carlos Eduardo Lima Machado. São Paulo: Martins Fontes, 2000.

CAHALI, Yussef. (Org.). Constituição Federal, Código Civil, Código de Processo Civil, Código Comercial. 9. ed. rev. ampl. e atual. São Paulo: Ed. Revista dos Tribunais, 2007.

CÂMARA DOS DEPUTADOS. Projeto de Lei n. 7.202/2010. Disponível em: <http://www.camara.gov.br/sileg/integras/761349.pdf>. Acesso em: 22 out. 2010. 
CAMPILONGO, Celso Fernandes. Os desafios do Judiciário: um enquadramento teórico. In: FARIA, José Eduardo (Org.). Direitos humanos, direitos sociais e justiça. São Paulo: Malheiros Ed., 2005.

. Política, sistema jurídico e decisão judicial. São Paulo: Max Limonad, 2002.

CAMUS, Albert. O mito de Sísifo. 4. ed. Rio de Janeiro: Record, 2007.

CAPRA, Fritjof. $O$ ponto de mutação: a ciência, a sociedade e a cultura emergente. Trad. Álvaro Cabral. 11. ed. São Paulo: Cultrix, 1990.

O Tao da Física: um paralelo entre a física moderna e o misticismo oriental. Trad. José Fernandes Dias. 21. ed. São Paulo: Cultrix, 2002.

CARROLL, Lewis. Alice's adventures in wonderland and through the looking-glass and what Alice found there. London: Penguin Classics, 2009.

CARVAlHO, Cristiano. Teoria do sistema jurídico: direito, economia, tributação. São Paulo: Quartier Latin, 2005.

CARVAlHO, Paulo de Barros. Direito tributário: fundamentos jurídicos de incidência. 2. ed. São Paulo: Saraiva, 1999.

CASSIRER, Ernst. Ensaio sobre o homem: introdução a uma filosofia da cultura humana. Trad. Rosa Bueno. São Paulo: Martins Fontes, 2001.

CASTRO, Carlos Roberto Siqueira. A constituição aberta e os direitos fundamentais: ensaios sobre o constitucionalismo pós-moderno e comunitário. Rio de Janeiro: Ed. Forense, 2003.

CHAVES, Marcelo Antonio. A trajetória do Departamento Estadual do Trabalho de São Paulo e a mediação das relações de trabalho (1911 e 1937). 2009. Tese (Doutorado em História) - Universidade Estadual de Campinas, Campinas, 2009.

CHEVALLIER, Jean-Jacques. As grandes obras políticas de Maquiavel a nossos dias. Trad. Lydia Christina. 3. ed. Rio de Janeiro: Agir, 1986.

CHIAPPIN, J. R. N. Direito e economia. Aula na disciplina de pós-graduação, oferecida no segundo semestre de 2008 e ministrada na Faculdade de Economia da Universidade de São Paulo. 
CHIAPPIN, J. R. N.; LEISTER, C. O programa de pesquisa sobre a política e o direito como ciência e o problema das condições de emergência e estabilidade da cooperação entre indivíduos interagentes: a construção do Estado de Direito e a heurística do contratualismo. Parte II. 2007. No prelo.

COMPARATO, Fábio Konder. A afirmação histórica dos direitos humanos. 2. ed. São Paulo: Saraiva, 2001.

Ética: direito, moral e religião no mundo moderno. São Paulo: Companhia das Letras, 2006.

CONSOLIDAÇÃO das Leis do Trabalho, Código de Processo Civil, Legislação Trabalhista e Processual Trabalhista, Legislação Previdenciária, Constituição Federal. Obra coletiva de autoria da Revista dos Tribunais. 10. ed. rev. ampl. e atual. São Paulo: Ed. Revista dos Tribunais, 2009.

COOTER, Robert; ULLEN, Thomas. Law and economics. $3^{\text {rd }}$. ed. Massachusetts: Addison Wesley Longman, 2000.

CORREIA, Marcus Orione Gonçalves. Por uma metodologia dos direitos humanos: uma análise na perspectiva dos direitos sociais. Revista do Departamento de Direito Trabalho e Seguridade Social da Faculdade de Direito da Universidade de São Paulo, São Paulo, v. 2. n. 4 , jul./dez. 2007.

COSTA, Marcelo Freire. Eficácia dos direitos fundamentais entre particulares: juízo de poderação no processo do trabalho. São Paulo: LTr, 2010.

COULANGES, Foustel de. A cidade antiga: estudos sobre o culto, o direito, as instituições da Grécia e de Roma. Trad. José Camargo Leite e Eduardo Fonseca. São Paulo: Hemus, 1975.

CRETELLA JÚNIOR, José. Curso de direito romano. Rio de Janeiro: Forense, 1968.

CRUET, Jean. À vida do direito e à inutilidade das leis. Leme: Edijur, 2002.

DANTAS, David Diniz. Interpretação constitucional no pós-positivismo: teoria e casos práticos. São Paulo: WCV Ed., 2004.

DEJOURS, Christophe; Florence Bègue. Suicídio e trabalho: o que fazer? Trad. Franck Soudant. Brasília: Paralelo 15, 2010.

DEMÓCRITO DE ABDERA. Fragmentos. In: BORNHEIM, Gerd A. (Org.). Os filósofos pré-socráticos. 12. ed. São Paulo: Cultrix, 2003. 
DEPARTAMENTO INTERSINDICAL DE ESTATÍSTICAS E ESTUDOS ECONÔMICOS - DIEESE. Nota técnica: argumentos para a discussão da redução da jornada no Brasil sem redução do salário. abr. 2008. Disponível em: $<$ http://www.dieese.org.br/notatecnica/notatec66argumentosReducaoJornada.pdf. Acesso em: 14 jun. 2008.

DEPARTAMENTO INTERSINDICAL DE ESTUDOS E PESQUISAS DE SAÚDE E DOS AMBIENTES DE TRABALHO - DIESAT. Anuário Estatístico de Acidentes de Trabalho. Disponível em: <http: //www.diesat.org.br/artigos/AEAT08.PDF>. Acesso em: 24 nov. 2010.

DESCARTES, René. Discurso do método. Trad. Enrico Corvisieri. In: DESCARTES, René. Descartes: vida e obra. Consultoria de José Américo Motta Pessanha. São Paulo: Nova Cultural, 1999. (Col. Os pensadores).

DE VINCENZO, Brunela Vieira de. Guinada semântica: indivíduo, pessoa, individualismo, individualização e sujeito de direitos fundamentais. In: NALINI, José Renato; NALINI, Angélica Carlini (Orgs.). Direitos humanos e formação jurídica. Rio de Janeiro: Forense, 2010.

DI PIETRO, Maria Sylvia Zanella. Direito administrativo. 18. ed. São Paulo: Atlas, 2005.

ELIADE, Mircea. Mito e realidade. Trad. Póla Civelli. São Paulo: Perspectiva, 2007. (Col. Debates, n. 52).

ENGELS, Friedrich; MARX, Karl. Manifesto do Partido Comunista. Petrópolis: Vozes, 1988.

FARIA, José Eduardo. Direito e economia na democratização brasileira. São Paulo: Malheiros Ed., 1993.

ـ As transformações do Judiciário em face de suas responsabilidades sociais. In:

_. Direitos humanos, direitos sociais e justiça (Org.). São Paulo: Malheiros Ed., 2005.

FERRAZ JÚNIOR, Tércio Sampaio. Direito constitucional: liberdade de fumar, privacidade, Estado, direitos humanos e outros temas. Barueri/SP: Manole, 2007.

Estudos de filosofia do direito: reflexões sobre o poder, a liberdade, a justiça e o direito. São Paulo: Atlas, 2002.

FERREIRA, Jorge. URSS: mito, utopia e história. Revista Tempo, Rio de Janeiro, v. 3, n. 5, 1998. 
FIORELLI, José Osmir et al. Psicologia aplicada ao direito. 3. ed. São Paulo: LTr, 2010.

FISCHER, Gustave-Nicolas. Os conceitos fundamentais da psicologia social. Lisboa: Instituto Piaget, 2002.

FISCHER, Rosa Maria Bueno. Foucault e a análise do discurso em educação. Cadernos de pesquisa, São Paulo, v. 114, nov. 2001. Disponível em: <www.scielo.br/pdf/cp/n114/a09n114.pdf>. Acesso em: 15 set. 2010.

FOUCAULT, Michel. El orden del discurso. Trad. Alberto González Troyano. Buenos Aires: Tusquets Editores, 1992.

. Vigiar e punir: história da violência nas prisões. Trad. Raquel Ramalhete. 22. ed. Petrópolis: Vozes, 2000.

FOUREZ, Gérard. A construção das ciências: introdução à filosofia e à ética das ciências. Trad. Luiz Paulo Rouanet. São Paulo: Ed. UNESP, 1995.

FRANCE. Conseil Constitutionnel. Constitution de 1791. Disponível em: $<$ http://www.conseil-constitutionnel.fr/conseil-constitutionnel/francais/la-constitution/lesconstitutions-de-la-france/constitution-de-1791.5082.html>. Acesso em: 20 jul. 2010.

. Conseil Constitutionnel. Constitution du 24 juin 1793. <http://www.conseilconstitutionnel.fr/conseil-constitutionnel/francais/la-constitution/les-constitutions-de-lafrance/constitution-du-24-juin-1793.5084.html>. Acesso em: 20 jul. 2010.

. Conseil Constitutionnel. Constitution du 5 Fructidor An III. Disponível em: $<$ http://www.conseil-constitutionnel.fr/conseil-constitutionnel/francais/la-constitution/lesconstitutions-de-la-france/constitution-du-5-fructidor-an-iii.5086.html>. Acesso em: 22 jul. 2010.

FRANZ, Marie-Louise Von. C. G. Jung: seu mito em nossa época. São Paulo: Cultrix, 1997.

FREIXES SANJUÁN, Teresa. Los derechos sociales de los trabajadores en la Constitución. Madrid: Centro de Publicaciones del Ministerio de Trabajo y Seguridad Social, 1986.

FROMM, Erich. Análise do homem. Trad. Octavio Alves Velho. 13. ed. Rio de Janeiro: Ed. Guanabara, 1986. O medo à liberdade. 7. ed. Rio de Janeiro: Zahar, 1970. 
FURTADO, Celso. Formação econômica do Brasil. 27. ed. São Paulo: Companhia Ed. Nacional; Publifolha, 2000. (Col. Grandes Nomes do Pensamento Brasileiro).

GALDINO, Flávio. Introdução à teoria dos custos dos direitos: direitos não nascem em árvores. Rio de Janeiro: Lumen Juris, 2005.

GARCIA, Gustavo Filipe Barbosa. Curso de direito do trabalho. São Paulo: Ed. Método, 2007.

Meio ambiente do trabalho: direito, segurança e medicina do trabalho. São Paulo: Ed. Método, 2006.

GILLISEN, John. Introdução histórica ao direito. Trad. A. Hespanha e L. M. Macaísta Malheiros. 3. ed. Lisboa: Fundação Calouste Gulbekian, 2001.

GIOCÓIA JÚNIOR, Oswaldo. Nietzsche. São Paulo: Publifolha, 2000.

GONZÁLEZ CASANOVA, Pablo. As novas ciências e as humanidades: da academia à política. Trad. Mouzar Benedito. São Paulo: Ed. Boitempo, 2006.

GORZ, André. Metamorfoses do trabalho: crítica da razão econômica. 2. ed. Trad. Ana Montoia. São Paulo: Annablume, 2007.

GOSDAL, Thereza Christina. Dignidade do trabalhador: um conceito construído sob o paradigma do trabalho decente e da honra. 2006. Tese (Doutorado em Direito) Universidade Federal do Paraná, Curitiba, 2006.

GUGGENBÜHL-CRAIG, Adolf. $O$ abuso do poder na psicoterapia e na medicina, serviço social, sacerdócio e magistério. Trad. Roberto Gambini. São Paulo: Paulus, 2004.

HERRERA FLORES, Joaquín. La construcción de las garantías: hacía una concepción antipatriarcal de al libertad y la igualdad. Revista do Departamento de Direito Trabalho e Seguridade Social da Faculdade de Direito da Universidade de São Paulo, São Paulo, v. 2, n. 4, jul/dez. 2007.

HOBBES, Thomas. Leviatã, ou matéria, forma e poder de um Estado eclesiástico e civil. Trad. Alex Marins. São Paulo: Martin Claret, 2002.

HOLlANDA, Sérgio Buarque de. Raízes do Brasil. 2. ed. São Paulo: Companhia das Letras, 2007.

HOLLIS, James. Rastreando os deuses: o lugar do mito na vida moderna. Trad. Maria Silvia Mourão Netto. São Paulo: Paulus, 1997. 
HOLMES, Stephen; SUNSTEIN, Cass R. The cost of rights: why liberty depends on taxes. New York: Norton \& Co., 1999.

HUNT, E. K. História do pensamento econômico: uma perspectiva crítica. Trad. Beatriz Vianna Boeira e Nelson Boeira. 2. ed. Rio de Janeiro: Elsevier, 2005.

ILOLEX. Database of International Labour Standards. Disponível em: <http://www.ilo.org/ilolex/english/newratframeE.htm>. Acesso em: 05 ago. 2010.

- Database of International Labour Standards. Disponível em: <http://www.ilo.org/ilolex/english/subjlst.htm>. Acesso em: 17 ago. 2010.

IMMORDINO, Giovanni; PAGANO, Marco. The costs of rights - an economic analysis. Diritto \& Questioni Pubbliche, Palermo, n. 4, ano 2004.

INSTITUTO BRASILEIRO DE GEOGRAFIA E ESTATÍSTICA - IBGE. Recenseamento Geral do Brasil (1º de setembro de 1940). Censo Demográfico - População e Habitação. Quadros de totais para o conjunto da União e de distribuição pelas regiões fisiográficas e unidades federadas. Série Nacional. Rio de Janeiro: Serviço Gráfico do Instituto Brasileiro de Geografia e Estatística, 1950. v. 2.

THE INTERNATIONAL LABOUR ORGANIZATION. Convention 1 - Hours of Work (Industry) Convention, $1919 . \quad$ Disponível em: <http://www.ilo.org/ilolex/english/convdisp1.htm>. Acesso em: 14 jun. 2008.

JAPIASSU, Hilton. Como nasce a ciência moderna - e as razões da Filosofia. Rio de Janeiro: Imago, 2007.

JOHNSON, Robert A. A Chave do Reino Interior. São Paulo: Ed. Mercuryo, 1989.

KIRCHGÄSSNER, Gebhard. Homo oeconomicus: the economic model of behaviour and its applications in economics and other social sciences. New York: Springer, 2008.

KUHN, Thomas S. A estrutura das revoluções científicas. Trad. José Ricardo Brandão Azevedo e Ma. José Cyhlar Monteiro. São Paulo: Perspectiva, 2007.

LAFER, Celso. A internacionalização dos direitos humanos: Constituição, racismo e relações internacionais. Barueri/SP: Manole, 2005.

LANER, Aline dos Santos. Psicologia e trabalho: da apropriação do tempo à busca da felicidade. Ijuí: Ed. Unijuí, 2005.

LAZZARINI, Alvaro. Estudos de direito administrativo. 2. ed. São Paulo: Ed. Revista dos Tribunais, 1999. 
LIPOVETSKY, Gilles. A felicidade paradoxal: ensaio sobre a sociedade de hiperconsumo. Trad. Maria Lucia Machado. São Paulo: Companhia das Letras, 2007. Os tempos hipermodernos. Trad. Mário Vilela. São Paulo: Ed. Barcarolla, 2004.

LOCKE, John. Dois tratados sobre o governo. Livro II. In: MORRIS, Clarence (Org). Os grandes filósofos do direito. Trad. Reinaldo Guarany. São Paulo: Ed. Martins Fontes, 2002.

LOPES, José Leite. A imagem física do mundo: de Parmênides a Einstein. Revista de Estudos Avançados. São Paulo, v 5, n.12. maio/ago.1991. Disponível em: $<$ <ttp://www.scielo.br/scielo.php?pid=S0103-40141991000200007\&script=sci_arttext $>$. Acesso em: 20 ago.2010.

LOUGHLIN, Michael. Ethics, management and mythology: rational decision making for health service professionals. Abingdon: Radcliffe Medical Press, 2002.

LUCE, J.V. Curso de filosofia grega: do séc. VI a.C. ao séc. III d.C. Trad. Mário da Gama Kury. Rio de Janeiro: Jorge Zahar, 1994.

LUHMANN, Niklas. Introdução à teoria dos sistemas: aulas publicadas por Javier Torres Nafarrate. Trad. Ana Cristina Arantes Nasser. Petrópolis: Ed. Vozes, 2009.

Sociologia do direito I. Trad. Gustavo Bayer. Rio de Janeiro: Edições Tempo Brasileiro, 1983.

. Sociologia do Direito II. Trad. Gustavo Bayer. Rio de Janeiro: Tempo Brasileiro, 1983.

MANNRICH, Nelson. Inspeção do trabalho. São Paulo: LTr, 1991.

MARCUS TULLIUS CICERO. De Republica, III, xxii, 33. In: D'ENTRÈVES, Alexander Passerin. Natural law: an introduction to legal philosophy. New Jersey: Transaction Publishers, 2004.

MARONI, Amnéris. Jung: o poeta da alma. 2. ed. São Paulo: Summus Editorial, 1998.

MARRAMAO, Giacomo. Poder e secularização: as categorias do tempo. Trad. Guilherme Alberto Gomes de Andrade. São Paulo: Ed. UNESP, 1995.

MARX, Karl. Da manufatura à fábrica automática. In: GORZ, André. Crítica da divisão do trabalho. Trad. Estela dos Santos Abreu. São Paulo: Martins Fontes, 2001. 
MATURANA, Humberto R.; VARELA, Francisco J. A árvore do conhecimento: as bases biológicas da compreensão humana. Trad. Humberto Mariatti e Lia Diskin. 6. ed. São Paulo: Palas Athena, 2007.

MELLO, Celso Antônio Bandeira de. Curso de direito administrativo. 19. ed. São Paulo: Malheiros Ed., 2005.

MELO, Maria Bernardete Fernandes Vieira de. Influência da cultura organizacional no sistema de gestão da segurança e saúde no trabalho em empresas construtoras. 2001. Tese (Doutorado em Engenharia de Produção) - Universidade Federal de Santa Catarina, Florianópolis, 2001.

MÉNARD, René. Mitologia greco-romana. Trad. Aldo Della Nina. São Paulo: Opus, 1991. v. 1 e v. 2.

MÉSZÁROS, István. A teoria da alienação em Marx. Trad. Isa Tavares. São Paulo: Boitempo, 2006.

MIAILLE, Michel. Introdução crítica ao direito. Trad. Ana Prata. 3. ed. Lisboa: Editorial Estampa, 2005.

MILL, John Stuart; BENTHAM, Jeremy. Utilitarism and other essays. London: Penguin Books, 2004.

MIRANDA, Custódio da Piedade Ubaldino. Teoria geral do negócio jurídico. São Paulo: Atlas, 1991.

MORAES, Aline. Trabalhadores vivenciam novo contexto de trabalho com maior exploração. Agência USP de Notícias, 01 fev. 2007. Disponível em: <http://www.usp.br/agen/repgs/2007/pags/010.htm>. Acesso em: 03 ago. 2010.

MORAES, Evaristo. Apontamentos de direito operário. 4. ed. São Paulo: LTr, 1998.

MÜLLER, Friederich. O novo paradigma do direito: introdução à teoria e metódica estruturantes. 2. ed. São Paulo: Ed. Revista dos Tribunais, 2009.

MUNHÊ, Vilma Pimenta Cirilo. Análise multicausal para a compreensão de acidentes de trabalho: um estudo de caso de uma empresa paranaense de alimentos. 2009. Dissertação (Mestre em Administração) - Universidade Federal do Paraná, Curitiba, 2009.

NASCIMENTO, Amauri Mascaro. Compêndio de direito sindical. 2. ed. São Paulo: LTr, 2000.

. Curso de direito do trabalho. 14. ed. São Paulo: Saraiva, 1997. 
NASCIMENTO, Amauri Mascaro. Curso de direito do trabalho. 20. ed. São Paulo: Saraiva, 2005.

Teoria geral de direito do trabalho. São Paulo: LTr, 1998.

NEVES, Marcelo. A constitucionalização simbólica. São Paulo: Martins Fontes, 2007.

NOGARE, Pedro Dalle. Humanismos e anti-humanismos: introdução à antropologia filosófica. 10. ed. Petrópolis: Vozes, 1985.

NOTÍCIAS DO TRIBUNAL SUPERIOR DO TRABALHO. Disponível em: $<$ http://ext02.tst.gov.br/pls/no01/no_noticias.Exibe_Noticia?p_cod_noticia=4581\&p_cod_ area_noticia=ASCS $>$. Acesso em: 23 jul. 2008.

OLIVEIRA, Paulo Eduardo Vieira de. O dano pessoal no direito do trabalho. São Paulo: LTr, 2002.

ORGANIZAÇÃO INTERNACIONAL DO TRABALHO. Inspeção do trabalho: manual de educação do trabalhador. Trad. Edilson Alkmin Cunha. São Paulo: LTr, 1994.

- L’inspection $d u$ travail: manuel d'éducation ouvrière. Genéve: Bureau International du Travail, 1986.

. Resolução n. 5. Disponível em: <http: //www.ilo.org/ilolex/english/recdisp1.htm>. Acesso em: 05 ago. 2010.

. Resolução n. 20, de 29 de outubro de 1923. Disponível em: <http://www.ilo.org/ilolex/cgi-lex/convde.pl?R020>. Acesso em: 05 ago. 2010.

PAPA LEÃO XIII. Rerum Novarum- Carta Encíclica de Sua Santidade o Papa Leão XIII sobre a condição dos operários. 12. ed. São Paulo: Paulinas, 2000.

PARETO, Vilfredo. Trasformazione della democrazia. Roma: Ed. Riuniti, 1999.

PASCAL, Blaise. Pensamentos. Trad. Mário Laranjeira. São Paulo: Martins Fontes, 2001.

PEDROSO, Marcelo Batuíra da C. Losso. Liberdade e irrenunciabilidade no direito do trabalho: do estudo dos princípios à "Economic Analysis of Law" aplicados aos Direito do Trabalho. Porto Alegre: Sérgio Antonio Fabris Editor, 2005.

PENA, Felipe. A perna coxa da tecnologia: fantasias totalitárias dos náufragos da polissemia na cibercultura. Revista Contracampo, Rio de Janeiro, v. 9, n. 0, 2005. Disponivel em: <http://www.revistas.univerciencia.org/index.php/contracampo/article/view/26/25>. Acesso em: 17 jan.2010. 
PEREZ LUÑO, Antonio Enrique. Derechos humanos, estado de derecho y constitución. 2. ed. Madrid: Tecnos, 1986.

PIETAVOLO, Maria Chiara. I padroni del discorso: Platone e la liberta della conoscenza. Pisa: Ed. Plus, 2003.

PINHEIRO, Armando Castelar; SADDI, Jairo. Direito, economia e mercados. Rio de Janeiro: Elsevier, 2005.

POLANYI, Karl. A grande transformação: as origens da nossa época. Trad. Fanny Wrobel. 2. ed. Rio de Janeiro: Elsevier, 2000.

POSNER, Richard A. Problemas de filosofia do direito. São Paulo: Martins Fontes, 2007.

PRADO, Lídia Reis de Almeida. O juiz e a emoção: aspectos da lógica da decisão judicial. 2. ed. Campinas: Millenium Ed., 2003.

O juiz e a emoção: aspectos da lógica formal. 4. ed. Campinas: Millennium, 2008.

PRADO JÚNIOR, Caio. História Econômica do Brasil. 43. ed. São Paulo: Brasiliense, 1998.

PROTEUS. Encyclopædia Britannica. 2009. Encyclopaedia Britannica Online. Disponível em: <http://www.britannica.com/EBchecked/topic/480043/Proteus>. Acesso em: 31 maio 2009.

REALE, Giovanni. O saber dos antigos: terapia para os tempos atuais. 2. ed. Trad. Silvana Corbucci Leite. São Paulo: Ed. Loyola, 2002.

RECASENS SICHES, Luis. Vida humana, sociedade y derecho: fundamentácion de la filosofía del derecho. 2. ed. México: Fondo de Cultura Económica, 1945.

RIBEIRO, Marcelo Afonso. Psicologia e gestão de pessoas: reflexões críticas e temas afins (ética, competência e carreira). São Paulo: Vetor, 2009.

RIFKIN, Jeremy. O fim dos empregos: o declínio inevitável dos níveis de empregos e a redução da força global de trabalho. Trad. Ruth Gabriela Bahr. São Paulo: Makron Books, 1995.

RIGAUX, François. A lei dos juízes. Trad. Edmir Missio. São Paulo: Martins Fontes, 2003. RIPERT, Georges. Aspectos jurídicos do capitalismo moderno. Campinas: Red Livros, 2002. 
RODRIGUES, Léo Peixoto. Sistemas auto-referentes, autopoiéticos: noções-chave para a compreensão de Niklas Luhmann. Revista Pensamento Plural, Pelotas, v. 3, jul./dez. 2008.

ROUSSEAU, Jean-Jacques. O contrato social. Trad. São Paulo: Nova Cultural, 1999. v. 1. (Col. Os pensadores).

SALENTO, Angelo. Postfordismo e ideologie giuridiche. Milano: Franco Angeli, 2003.

SANFORD, John A. Os parceiros invisíveis: o masculino e o feminino dentro de cada um de nós. 4. ed. São Paulo: Paulinas, 1986.

SANTOS, Maria Celeste C. Leite. Poder jurídico e violência simbólica: problemas do poder, na obra póstuma de Hans Kelsen “Allgemeine Theorie Der Normen”. São Paulo: Cultural Paulista, 1985.

SARLET, Ingo Wolfgang. A eficácia dos direitos fundamentais. 3. ed. Porto Alegre: Livr. do Advogado, 2003.

As dimensões da dignidade humana. Revista Brasileira de Direito Constitucional $-R B D C$, n. 9, jun./jul.2007.

SARMENTO, Daniel. Direitos fundamentais e relações privadas. Rio de Janeiro: Lumen Juris, 2004.

SARTRE, Jean-Paul. L'existentialisme est un humanisme. Paris: Edition Gallimard, 1996.

SCOTT, Joan. O enigma da igualdade. Revista de Estudos Feministas, Florianópolis, v. 13, n. 1 , jan./abr. 2005.

SELIGMANN-SILVA, Edith. Origens e constituição do desgaste mental relacionado ao trabalho: contextos externos ao trabalho e contextos de trabalho. Texto síntese organizado e enviado pela Prof $^{a}$ Edith Seligman. Mar. 2010. São Paulo. Disponível em: $<$ http://www.moodle.fmb.unesp.br/file.php?file=\%2F52\%2FMateriais_e_links\%2FPublica coes\%2FEdith_Seligman\%2FORIGENS_E_CONSTITUICAO_DO_DESGASTE_MENT AL.pdf>. Acesso em: 31 ago. 2010.

[Textos].

Disponível

em:

$<$ http://www.moodle.fmb.unesp.br/file.php?file=\%2F52\%2FEncontros $\% 2$ F2010\%2FProdu cao_social_dos_AT\%2FEdith_-_ACIDENTES_TRABALHO_PSIQUISMO.pdf>. Acesso em: 31 ago. 2010.

SEN, Amartya. Sobre ética e economia. Trad. Laura Teixeira Motta. São Paulo: Companhia das Letras, 2002. 
SENADO FEDERAL. Comissão de Constituição e Justiça e Cidadania. Parecer sobre Projeto de Lei $n^{\circ}$ 7.124, DE 2002 (Apensados os Projetos de Lei $n^{\circ}$. 1.443/2003, 1.914/2003 e 7.329/2010). Disponível em: <http://www.camara.gov.br/sileg/integras/777390.pdf>. Acesso em: 22 out. 2010.

SENNETT, Richard. Autoridade. Trad. Vera Ribeiro. Rio de Janeiro: Record, 2001. A corrosão do caráter: consequências pessoais do trabalho no novo capitalismo. 14. ed. Trad. Marcos Santarrita. Rio de Janeiro: Record, 2009.

SHAPIRO, Sidney A. Occupational safety and health regulation. Encyclopedia of Law and Economics. Disponível em: <http://encyclo.findlaw.com/5540book.pdf>. Acesso em: 10 dez. 2008.

SILVA, Leandro Santos da; OLIVEIRA, Manoel Messias de. Os sentidos em Descartes: fonte de erro ou de conhecimento. Revista da Católica, Uberlândia, v. 1, n. 1, 2009. Disponível em: <www.catolicaonline.com.br/revistadacatolica>.

SILVA, Leonardo Mello e. Trabalho e reestruturação produtiva: o desmanche da classe. In: OLIVEIRA, Francisco de; RIZEK, Cilebe Saliba (Orgs.). A era da indeterminação. São Paulo: Boitempo, 2007.

SILVA, Walküre Lopes Ribeiro da. Direito do trabalho brasileiro: principais aspectos de sua evolução histórica e as propostas de modernização. Revista do Tribunal Superior do Trabalho, Brasília, v. 69, n. 2, jul./dez. 2003.

SIMÃO, Azis. Sindicato e Estado: suas relações na formação do proletariado de São Paulo. São Paulo: Dominus Ed., 1966.

SMITH, Adam. An inquiry into the nature and causes of the wealth of nations. Chicago: Enciclopedia Britannica, 1952. . Teoria dos sentimentos morais. Trad. Lya Luft. São Paulo: Martins Fontes, 2002.

SODER, José. Direitos do homem. São Paulo: Companhia Editora Nacional, 1960.

STEIN, Murray. Jung: o mapa da alma: uma introdução. São Paulo: Cultrix, 1998.

STOCCO, Rui. Tratado de responsabilidade civil: responsabilidade civil e sua interpretação doutrinária e jurisprudencial. 5. ed. São Paulo: Ed. Revista dos Tribunais, 2001. 
SUPREMO TRIBUNAL FEDERAL, 2 ${ }^{\text {a }}$ Turma. RE n. 201819/RJ. Rel. Ministro Gilmar Mendes. Diário de Justiça, 27 out. 2006. p. 577. Disponível em: $<$ http://www.stf.jus.br/portal/diarioJustica/verDiarioProcesso.asp?numDj=207\&dataPublic

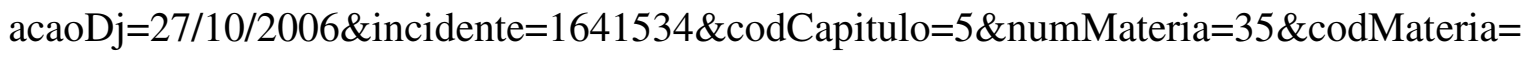
3>. Acesso em: 15 out. 2010.

SÜSSEKIND, Arnaldo. Direito do trabalho: temas em aberto. São Paulo: LTr, 1998.

SZTAJN, Rachel. Law and economics. In: ZYLBERSZTAJN, Decio; SZTAJN, Rachel. (Orgs.) Direito \& economia: análise econômica do direito e das organizações. Rio de Janeiro: Elsevier, 2005.

TABAK, Bernardo. Jovem que perdeu braço em triturador diz que não recebeu treinamento. Gl RJ. Disponível em: <http://g1.globo.com/rio-dejaneiro/noticia/2010/08/operario-que-perdeu-o-braco-em-fabrica-de-massas-deixahospital.html>. Acesso em: 25 ago. 2010.

TELLES JÚNIOR, Goffredo da Silva. A folha dobrada: lembranças de um estudante. Rio de Janeiro: Nova Fronteira, 1999.

TEUBNER, Gunther. Altera pars auditur: law in collision of discourses. In: RAWLINGS, Richard. Law, society and economy - Centenary Essays for the London School of Economics and Political Science, 1895-1995. Oxford: Oxford University Press, 1997.

; FEBBRAJO, Alberto. Autonomy and regulation in the autopoietic perspective: an introduction. In: In: State, law and economy as autopoietic systems: regulation and autonomy in a new perspective. Milano: Giuffrè, 1992.

THÉBAUD-MONY, Annie; DRUCK, Graça. Terceirização: a erosão dos direitos dos trabalhadores na França e no Brasil. In: DRUCK, Graça; FRANCO, Tânia. A perda da razão social do trabalho: terceirização e precarização. São Paulo: Boitempo Editorial, 2007.

TRIBUNAL REGIONAL DO TRABALHO DA 2a REGIÃO. Processo TRT/SP 01773200603302007 - RO - Ac. 4aT 20090386919 - Rel. Ivani Contini Bramante, publicado no DOE 29/05/2009. Disponível em: <http://www.trtsp.jus.br/. Acesso em: 01 out. 2010.

TUGENDHAT, Ernst. Lições sobre ética. Trad. Robson Ramos dos Reis. 5. ed. Petrópolis: Vozes, 2003.

TV JUSTIÇA. Sessão plenária de 30.04.2008. Disponível em: <http://videos.tvjustica.gov.br/?video=1301>. Acesso em: 16 jun.2008. 
VASCONCELlOS, Maria José Esteves de. Pensamento sistêmico: o novo paradigma da ciência. 7. ed. Campinas: Papirus, 2002.

VASCONCELOS, Arnaldo. Direito, humanismo e democracia. São Paulo: Malheiros, 1998.

VILELA, Rodolfo Andrade Gouveia et al. Culpa da vítima: um modelo para perpetuar a impunidade nos acidentes de trabalho. Caderno de Saúde Pública, Rio de Janeiro, v. 20, n. 2, mar/abr. 2004.

VILELA, Sérgio Luiz de Oliveira. Racionalização e globalização: uma leitura a partir de Max Weber. Raízes: revista de ciências sociais e econômicas, Campina Grande, ano 18, v. 19, 1999. Disponível em: <www.ufcg.edu.br/ raizes/artigos/Artigo_43.pdf>. Acesso em: 01 ago. 2010.

WEBER, Max. Ciência e política: duas vocações. Trad. Jean Melville. São Paulo: Martin Claret, 2002.

A ética protestante e o espírito do capitalismo. Trad. Pietro Nassetti. São Paulo: Martin Claret, 2007. 